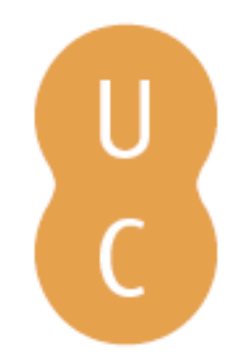

\title{
nommalina
}

\section{FESTEA - Tema clássico: dez anos de um festival de teatro (1999-2008)}

Publicado por: Centro de Estudos Clássicos e Humanísticos

URL persistente:

URI:http://hdl.handle.net/10316.2/2329

DOI:

DOI:http://dx.doi.org/10.14195/978-989-721-067-9

Accessed : $\quad$ 26-Apr-2023 14:00:40

A navegação consulta e descarregamento dos títulos inseridos nas Bibliotecas Digitais UC Digitalis, UC Pombalina e UC Impactum, pressupõem a aceitação plena e sem reservas dos Termos e Condições de Uso destas Bibliotecas Digitais, disponíveis em https://digitalis.uc.pt/pt-pt/termos.

Conforme exposto nos referidos Termos e Condições de Uso, o descarregamento de títulos de acesso restrito requer uma licença válida de autorização devendo o utilizador aceder ao(s) documento(s) a partir de um endereço de IP da instituição detentora da supramencionada licença.

Ao utilizador é apenas permitido o descarregamento para uso pessoal, pelo que o emprego do(s) título(s) descarregado(s) para outro fim, designadamente comercial, carece de autorização do respetivo autor ou editor da obra.

Na medida em que todas as obras da UC Digitalis se encontram protegidas pelo Código do Direito de Autor e Direitos Conexos e demais legislação aplicável, toda a cópia, parcial ou total, deste documento, nos casos em que é legalmente admitida, deverá conter ou fazer-se acompanhar por este aviso.

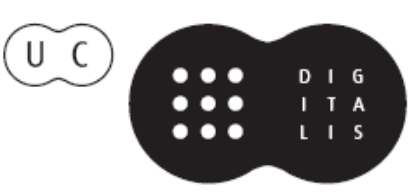


CARLOS A. MARTINS DE JESUS

LUÍSA DE NAZARÉ FERREIRA

\section{FESTEA- Tema Clássico}

Dez Anos de um Festival de Teatro

(1999-2008)

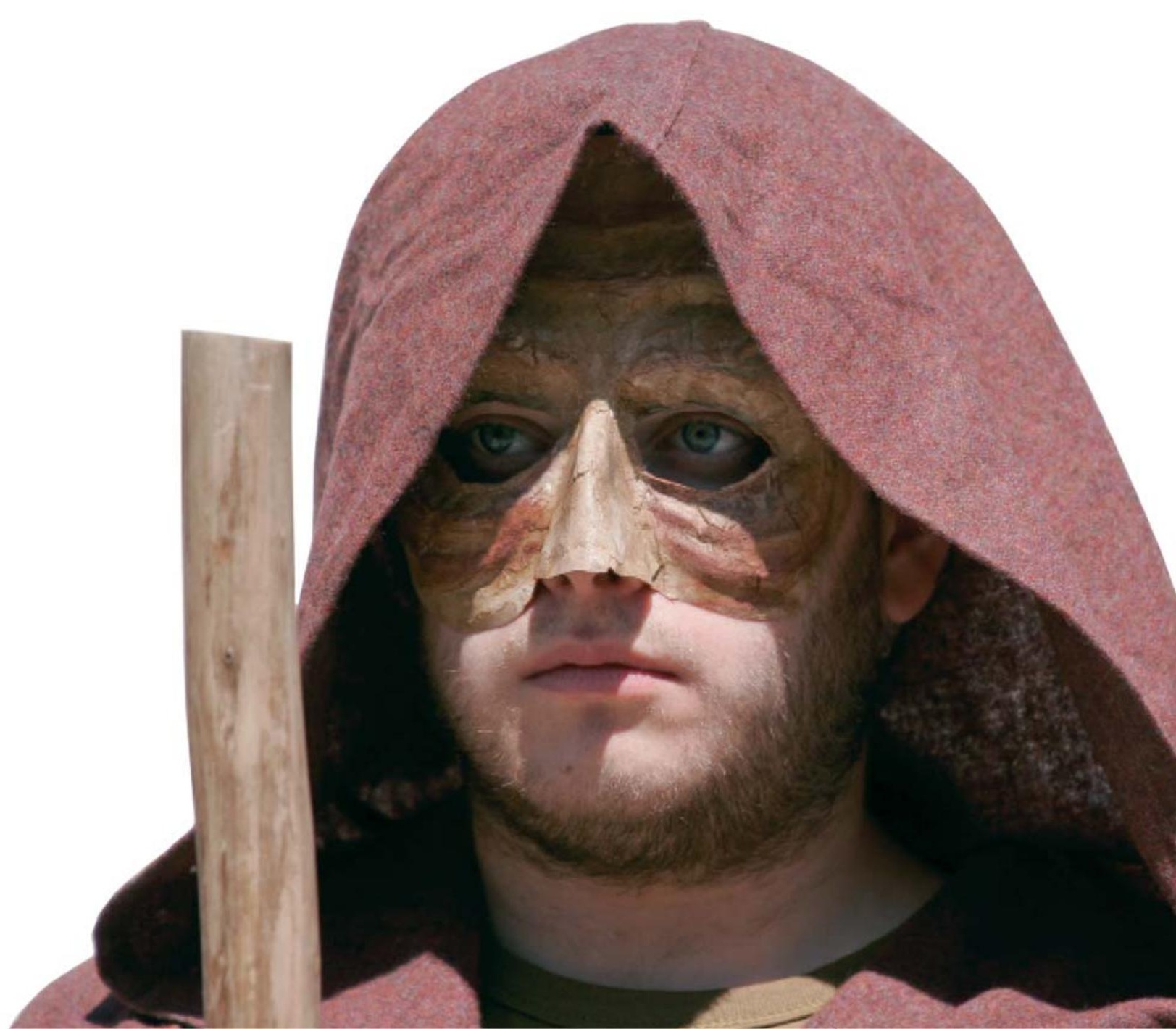




\section{FESTEA - Tema Clássico}

Dez Anos de um Festival de Teatro (1999-2008)

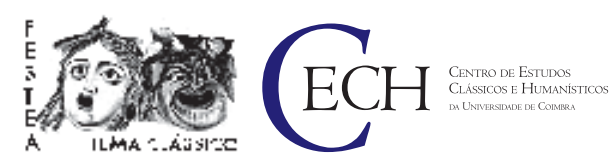


Organizadores

Carlos A. Martins de Jesus, Luísa de Nazaré Ferreira

Título

FESTEA - Dez Anos de um Festival de Teatro (1999-2008)

EDITOR

Centro de Estudos Clássicos e Humanísticos

Edição

$1^{\mathrm{a} / 2010}$

Coordenador Científico do Plano de Edição

Maria do Céu Fialho

Conselho Editorial

José Ribeiro Ferreira, Maria de Fátima Silva,

Francisco de Oliveira, Nair de Castro Soares

Director Técnico da Colecção

Delfim Ferreira Leão

Autores dos textos

Ana Seiça Carvalho, Aníbal Rocha, Carlos A. Louro da Fonseca, Carlos A. Martins de Jesus, Carlos Morais, Carmen Leal Soares, Chantal Collion, Delfim Ferreira Leão, Emilio Flor, Isabel Melo e Silva, José Luís Navarro, José Ribeiro Ferreira, Luísa de Nazaré Ferreira, Maria de Fátima Silva, Maria do Céu Fialho, Mário Paulo Martins, Paulo Sérgio Ferreira

Concepção Gráfica e Paginação

Carlos A. Martins de Jesus

CAPA

Carlos A. Martins de Jesus, sobre foto de José Antunes

Desenhos originais

Catarina Ferreira

IMPRESSÃO

Simões \& Linhares, Lda.

Av. Fernando Namora, no 83 - Loja 4

3030-185 Coimbra

Obra Realizada no Âmbito das actividades da UI\&D Centro de Estudos Clássicos e Humanísticos

Universidade de Coimbra

FACUldade DE LeTras

TEL.: 239859981 | FAX: 239836733

ISBN: 978-989-828I-2I-O

Depósito Legal: 306475/10

(C) Centro de Estudos Clássicos e Humanísticos da Universidade de Coimbra C Classica Digitalia Vniversitatis Conimbrigensis

Publicado no Âmbito do Programa POCI 2010 - Fundação para a

Ciência e a Tecnologia

Reservados todos os direitos. Nos termos legais fica expressamente proibida a reprodução total ou parcial por qualquer meio, em papel ou em edição electrónica, sem autorização expressa dos titulares dos direitos. É desde já excepcionada a utilização em

circuitos académicos fechados para apoio a leccionação ou extensão cultural por via de e-learning. 


\title{
ÍNDICE
}

\author{
Prefácio \\ 7
}

OS COMEÇOS

José Ribeiro Ferreira

9

10 ANOS DE SENSAÇÕES EFÉMERAS

E DE EMOÇÕES ETERNAS

Delfim Ferreira Leão

12

FEstival INTERNACIONAL

de Teatro de Tema Clássico

DEZ ANOS DE ACTIVIDADE

$\begin{array}{rl}1999 & 2004 \\ 16 & 78 \\ 2000 & 2005 \\ 30 & 92 \\ 2001 & 2006 \\ 38 & 106 \\ 2002 & 2007 \\ 54 & 110 \\ 2003 & 2008 \\ 68 & 118\end{array}$

OS LIVROS-BILHETE 133

GRUPOS PARTICIPANTES E ESPAÇOS 141

ÍNDICE DE ESPECTÁCULOS 


\section{PREFÁCIO}

Neste volume se contemplam dez anos daquele que é, em Portugal, o único festival de teatro inteiramente dedicado aos autores e temas clássicos. De natureza essencialmente universitária e amadora - o que não impossibilitou, pontualmente, a integração de grupos profissionais -, o Festival de Teatro de Tema Clássico, na sua dupla vertente de Festival Escolar e Festival Internacional de Verão, tem sido um dos veículos mais eficazes da divulgação da cultura greco-romana em Portugal, tarefa conseguida, em parte, graças ao seu carácter marcadamente itinerante.

Optámos por organizar este livro por forma a que o seu leitor pudesse ter acesso de forma rápida e intuitiva à maioria das produções teatrais e musicais apresentadas nos Festivais. Em cada ano, os programas completos dos espectáculos exibidos pela primeira vez são seguidos do material específico de cada actuação, onde se incluem sinopses, fichas técnicas, fotografias, cartazes e outro tipo de material publicitário. Buscámos acima de tudo a organização de um catálogo de espectáculos, recorrendo, sempre que possível, a textos da autoria de especialistas da área dos Estudos Clássicos, impressões sobre os textos e a sua mise en scène que, de alguma maneira, conferem ao livro uma evidente dimensão crítica. Também não foi descurada a projecção mediática do Festival, pelo que são reproduzidas, a cada passo, notícias da imprensa escrita.

Dois textos iniciais, da autoria de José Ribeiro Ferreira e de Delfim Ferreira Leão, os dois presidentes da associação promotora dos Festivais (FESTEA - Tema Clássico), reflectem sobre aspectos preliminares. Assim, o texto de José Ribeiro Ferreira - o grande mentor e dinamizador deste Festival - aborda os primeiros anos, realçando os intuitos fundamentais que presidiram à sua criação, resultado de contactos informais que se vinham fazendo com grupos e associações de Espanha. Delfim Ferreira Leão, o presidente em exercício, procura elaborar uma síntese dos dez anos ilustrados no volume, destacando a importância da divulgação do teatro clássico e dos seus valores nos nossos dias.

Além do catálogo dos livros-bilhete editados, que ascendem já às três dezenas, o Índice de Espectáculos permite, entre outras coisas, ter uma ideia clara da quantidade 
de peças levadas à cena no âmbito dos Festivais, sendo que, no que aos textos de teatro clássico conservados diz respeito, se pode ver como, por iniciativa do FesteA, pisaram já os palcos nacionais três de Ésquilo, seis de Sófocles, onze de Eurípides, seis de Aristófanes (de onze), um de Menandro, doze de Plauto e um de Terêncio. Dados que, no global, constituem uma confortável percentagem do total das peças antigas que chegaram até nós. Basta para isso pensarmos, por exemplo, no caso de Ésquilo (sete peças preservadas) ou de Sófocles (do qual apenas o Ájax não teve ainda uma apresentação). Igualmente importante é a lista, que se procurou ser completa, dos grupos participantes, além dos espaços e instituições que, ao longo dos anos, se associaram à missão do Festival de Teatro de Tema Clássico. Que a todos eles o presente livro possa servir de tributo - eis um dos grandes objectivos dos seus organizadores.

Passados dez anos - e, à data em que estas páginas vêm a lume, quase outros dois - é com grande alegria que apresentamos este catálogo. Julgamos também cumprir uma função documental, ao publicar as memórias de um festival de teatro, o único do seu género em terras portuguesas, que agora ficam acessíveis a curiosos, estudiosos, actores e encenadores. Num tempo em que a encenação de peças clássicas em Portugal, por companhias profissionais, tem vindo a crescer de forma surpreendente - reflexo de um reconhecimento do seu valor que, tardio ou não, é sem dúvida merecido -, estamos pois confiantes em que o presente volume faz todo o sentido.

Abra-se o pano! Que vos saiba bem o espectáculo!

Carlos A. Martins de Jesus Luísa de Nazaré Ferreira 


\section{OS COMEÇOS}

Vários foram os factores que estiveram na origem da ideia de realizar um Festival de Teatro de Tema Clássico. Em primeiro lugar, a consciência de que a cultura clássica criou valores intrínsecos de grande relevância que estão na base do viver e sentir do homem moderno. Mas também, em aproximado patamar de importância, a noção de que o teatro exerceu papel de relevo na transmissão dos ideais, temas e mitos greco-romanos que, parte integrante da cultura de hoje, continuam a ser utilizados por autores contemporâneos para expressarem anseios, preocupações, vivências. Tenha-se em conta que o teatro helénico e latino estava profundamente implicado na vida e na formação do homem e do cidadão, que equacionava perante o público problemas de piedade e de insolência, situações de medição das forças humanas com as do destino e questões de justiça; que abordava assuntos do dia a dia, quer o homem fosse visto como elemento da sociedade, a pólis, quer observado como indivíduo sujeito ao jogo de interesses e paixões.

Foi essa noção e crença que levou o Instituto de Estudos clássicos - aproveitando a circunstância de ter entre o seu corpo docente pessoas com gosto e apetência para a representação - a promover a criação de um grupo de teatro, oficializado em 1998, a que depois foi dado o nome feliz de Thíasos (do grego thiasos que no período helenístico e na actual língua grega se aplica às companhias de teatro). Talvez não seja descabido referir que a gestação do grupo se vinha a processar desde 1991, ano em que alguns alunos encenaram Sé Velha - Pedras Vivas, da autoria de Delfim Leão. Esses mesmos estudantes, a que outros se associaram, representaram parte do Soldado Fanfarrão de Plauto, em tradução e encenação de Carlos A. Louro Fonseca (1992); produziram um vídeo, cuja rodagem decorreu em Conimbriga, de As Mulheres no Parlamento de Aristófanes, com direcção de Delfim Leão (1996); apresentaram o Auto da Alma de Gil Vicente (1997) e o Epídico de Plauto (1998), encenados por José Luís Brandão e Paulo Sérgio Ferreira, respectivamente - duas peças que obtiveram significativo êxito, em especial a última, e consolidaram o grupo em definitivo. Nesse mesmo ano de 1998, actuou em Coimbra (Museu Nacional Machado de Castro) o Grupo de Teatro Clásico Griego ‘Selene’ (Instituto Enseñanza Secundaria Carlos III, de Madrid) que, a solicitação do Instituto de Estudos Clássicos, aqui veio apresentar a Andrómaca de 
Eurípides e endereçou o convite a alguns professores do Instituto - entre os quais estava o signatário destas linhas - para participarem, como observadores, no Festival de Teatro Grecoromano de Segóbriga. Aí assistiram a várias peças com cerca de duas mil pessoas, na sua grande maioria estudantes, a vibrarem ou seguirem interessadas as representações.

Era então Directora de Conimbriga a Dra Adília Alarcão que sempre procurara valorizar o local arqueológico com representações dramáticas e chegou a promover, juntamente com a Liga de Amigos de Conimbriga, a criação de um grupo de teatro - o Grupo de Teatro Clássico de Conimbriga, de fugaz existência.

Foi a conjugação de todas essas circunstâncias - em especial a aceitação pelo público da representação do Auto da Alma e do Epídico - e o facto de continuarmos a acreditar nas possibilidades formativas do teatro greco-romano e no seu nada despiciendo papel pedagógico que fez nascer - quase impôs - a criação de um festival de teatro clássico e a promoção de representação de obras do teatro greco-romano ou de espectáculos com ele relacionados.

E assim, promovido pelo Instituto de Estudos Clássicos, Museu de Conimbriga e Liga de Amigos de Conimbriga, iniciou-se em 1999 com o nome de Encontros de Teatro de Tema Clássico Conimbriga - Aeminium - Sellium, associando três cidades já com existência no tempo dos Romanos, que passaram a designar-se desde 2001 Festival de Teatro de Tema Clássico. Nos anos seguintes, o Festival estendeu-se a Viseu, a Braga, a Odrinhas (Sintra), a várias outras localidades, como se pode ver no decurso desta publicação, e foi criada uma associação para o organizar (5 de Março de 2002): Festival de Teatro de Tema Clássico - Associação Promotora, que adoptou a sigla FesteA - Tema Clássico. Os espectáculos, pensados para serem apresentados ao ar livre, decorrem em locais históricos e contribuem para mútua valorização: animam os espaços monumentais e deles recebem enquadramento e cenário que os valorizam.

Visando melhor aproveitamento e compreensão das representações, quer através da prévia preparação e exploração nas escolas, quer pela leitura posterior, foram distribuídos, como bilhete, os textos encenados, integrais, em pequenos livros de bolso. Considerou, e considera ainda, a organização que, dessa forma, mediante esse trabalho antecipado e a releitura subsequente, além de se divulgar o teatro, se contribui de forma significativa para a formação do gosto pelo espectáculo teatral e se promove também a leitura.

Não foram fáceis os primeiros anos do Festival, com o desânimo a pairar, a cada passo, como ave de rapina. Aos poucos, porém, foi-se impondo, e hoje tem público fiel, sobretudo em determinadas cidades. Se de início a Liga de Amigos de Conimbriga teve 
papel relevante no lançamento das suas estruturas, o Festea e o Thíasos passaram depois a liderar e a assumir por inteiro a sua organização, de maneira a agilizar o processo de montagem do Festival.

E o Festival de Teatro de Tema Clássico, apesar dos seus curtos dez anos, parece já ter ultrapassado a fase de adolescência e tem potencialidades para continuar o seu caminho e a sua missão.

José Ribeiro Ferreira 


\section{ANOS DE SENSAÇÕES EFÉMERAS E DE EMOÇÕES ETERNAS}

Dez anos de actividade, duzentos e quarenta e dois espectáculos de teatro e de música, cinquenta mil espectadores e igual número de livros-bilhete distribuídos. Se o limite de caracteres não deixasse escrever mais do que duas parcas linhas, bastaria a frase anterior para resumir a essência da actividade do Festea - Festivais de Teatro de Tema Clássico, ao longo da sua primeira década de existência. Chegaria para fornecer dados estatísticos, aos quais há que reconhecer alguma pertinência e validade, mas seria claramente insuficiente para registar o que se procurou captar ao longo deste volume: a própria natureza efémera das artes performativas. À letra, efémero denomina aquilo que ‘dura um dia apenas’ e, quando aplicado a um espectáculo cénico ou musical, essa designação reduz-se ainda mais, confluindo nos breves instantes de uma ou duas horas de actuação. De fora, ficam os extensos meses de montagem das produções, de organização dos eventos, a saga dos contactos e a demanda incerta de apoios, o trabalho logístico, geralmente relegado para as margens da penumbra e do anonimato. Contudo, mesmo fazendo justiça ao peso determinante destes agentes, será ainda assim necessário compreender que, na realidade, todos eles são acessórios, porque se encontram ao serviço do fim último que é o espectáculo.

Embora o FESTEA sempre tenha acolhido performances musicais, o que caracteriza a sua actividade consiste sobretudo na promoção do teatro. O vocábulo grego theatron é um dos termos que mais fortuna haveria de ter na história da cultura. Etimologicamente relacionado com o verbo theaomai, 'ver', parece indiciar que, na origem, o teatro era sobretudo um tipo de manifestação artística destinada a deleitar os olhos. A ser assim, a palavra - proferida, recitada ou cantada - teria inicialmente um peso bastante reduzido ou até talvez não existisse de todo, ao menos com a densidade, elevação e grandeza a que a tragédia grega nos habituou, logo a partir de Ésquilo. E é precisamente ao peso esmagador do logos dramático que se deve muitas vezes a tentação de crer que o teatro antigo dispensava todos os códigos cénicos, para centrar-se unicamente no livre curso das 'palavras aladas', para recorrer à feliz expressão da epopeia homérica. Não era, porém, assim. O teatro clássico identificava-se mais com uma 
forma de arte complexa e total, onde havia texto, música, dança e também um poderoso impacto visual, conseguido graças à cenografia, à cuidada elaboração do vestuário, a 'efeitos especiais' simples mas eficazes, ao movimento potenciado, em especial no teatro grego, pela presença em cena da verdadeira moldura humana que é o coro - de doze, quinze, vinte e quatro elementos - e não a pálida e envergonhada aparição a que regra geral se vê reduzido em reposições modernas. Teria de ser um espectáculo, em toda a extensão abarcada pelo termo latino: spectaculum deriva de specto, que não significa apenas 'ver' (esse é o sentido do verbo simples specio), mas antes ‘observar com toda a atenção’. De facto, o teatro estava pensado para motivar emoções que deveriam perdurar na memória, não só por causa dos grandes dilemas e questões que suscitava, mas também enquanto experiência sensorial e plástica intensa.

É nesta aparente contradição que reside a essência da representação teatral: durar apenas uns instantes, ser uma experiência efémera, única e irrepetível, mas garantir, com a mesma generosidade das grandes criações artísticas, a intemporal aptidão para ser continuamente revisitada e refeita em renovadas metáforas da existência humana. É essa, também, a marca distintiva dos grandes clássicos gregos e latinos, que perpassaram, incólumes, a poalha dos tempos, a fim de se oferecem à inquietação e ao deleite. Para resgatá-los do passado, há que saber traduzi-los, na dupla acepção de os verter para uma outra língua, mas também de os adaptar a esse processo de apropriação que é todo o ensaio hermenêutico, toda a operação de (re)leitura e de interpretação. Por isso, ao longo desta década o FESTEA esforçou-se para que cada espectador fosse também um leitor e, pela mesma razão, o texto original, que ainda não é teatro, mas onde está latente a experiência performativa, foi vertido para português e publicado em livro de bolso, servindo também de bilhete em todas as produções apresentadas.

Além da sensibilização para as artes performativas e para a leitura, a organização dos Festivais procurou também que os espectadores se sentissem motivados a visitar locais com interesse arqueológico. Para isso, em vez da tradicional representação em espaço fechado, foi privilegiado o enquadramento cénico ao ar livre, que levou à valorização do património arquitectónico nacional, reforçando assim não apenas o carácter único da performance, bem como a natureza itinerante e descentralizada desta iniciativa cultural. É por este conjunto de valências, cuja concretização dependeu do contributo de centenas de pessoas, que as actividades do Festea se traduziram, nesta dezena de anos, num poderoso meio de divulgação da cultura greco-latina e sua 
perenidade, bem como numa expressão particularmente elucidativa da articulação entre investigação avançada, inovação pedagógica, transferência de saberes e divulgação da cultura científica.

Aos artistas, aos mecenas e aos espectadores que tornaram possível a confluência, num mesmo projecto, de cinquenta mil sonhos - o nosso muito obrigado.

O Presidente da Direcção do FesteA, Delfim Ferreira Leão 
Festival Internacional de Teatro de Tema Clássico

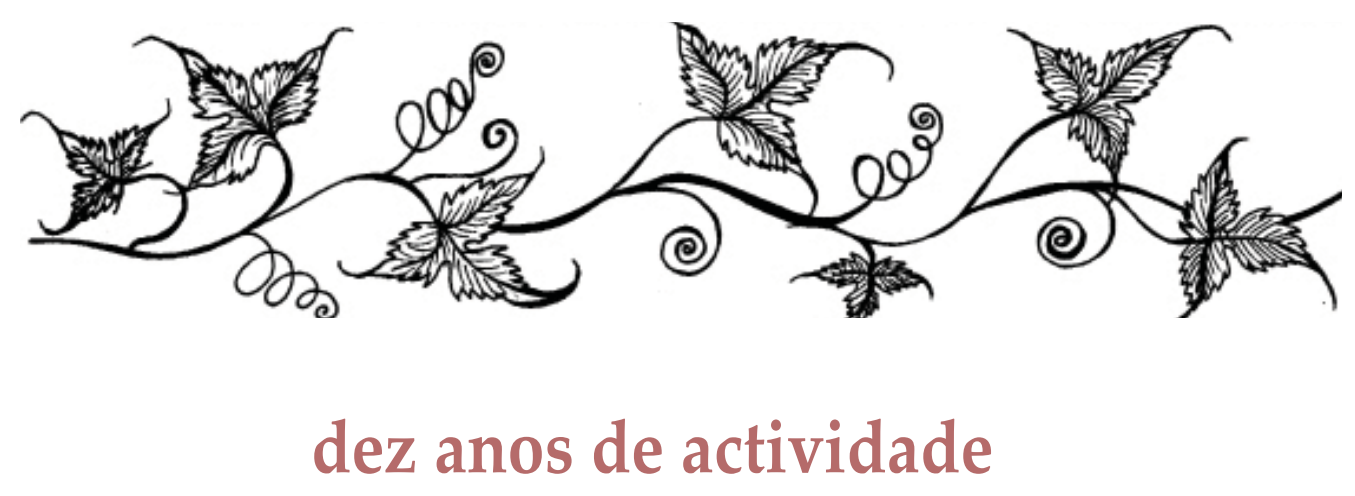


22 de Maio de 1999, 19.00 horas, Conimbriga Dido e Eneias de H. Purcell, grupo Canto e Drama, Conservatório de Música de Coimbra

26 de Junho de 1999, 21.30 horas, Páteo da Universidade de Coimbra Samia de Menandro, grupo Hélios de Madrid

27 de Junho de 1999, 18.00 horas, Museu Nacional Machado de Castro Epídico de Plauto, grupo Thíasos do IEC

18 de Julho de 1999, 18.00 horas, Conimbriga Epídico de Plauto, grupo Thíasos do IEC

22 de Julho de 1999, 18.00 horas, Conimbriga Epídico de Plauto, grupo Thíasos do IEC

24 e 25 de Julho de 1999, 21.30 horas, Conimbriga Os Persas de Ésquilo, grupo A Escola da Noite de Coimbra

31 de Julho de 1999, 21.30 horas, Páteo da Universidade de Coimbra Mitos Clássicos na Poesia Portuguesa Contemporânea, grupo de Teatro Clássico de Conimbriga

1 de Agosto de 1999, 21.30 horas, Tomar Epídico de Plauto, grupo Thíasos do IEC

8 de Agosto de 1999, 21.30 horas, Tomar Mitos Clássicos na Poesia Portuguesa Contemporânea, grupo de Teatro Clássico de Conimbriga

22 de Agosto de 1999, 18.00 horas, Conimbriga Viriato de João Aguiar, grupo Fatias de Cá de Tomar

4 de Setembro de 1999, 18.00 horas, Conimbriga Mitos Clássicos na Poesia Portuguesa Contemporânea, grupo de Teatro Clássico de Conimbriga

5 de Setembro de 1999, 18.00 horas, Conimbriga Viriato de João Aguiar, grupo Fatias de Cá de Tomar

18 de Setembro de 1999, 18.00 horas, Conimbriga Mitos Clássicos na Poesia Portuguesa Contemporânea, grupo de Teatro Clássico de Conimbriga

19 de Setembro de 1999, 18.00 horas, Conimbriga Viriato de João Aguiar, grupo Fatias de Cá de Tomar

30 de Setembro de 1999, 21.30 horas, Museu Nacional Machado de Castro Mitos Clássicos na Poesia Portuguesa Contemporânea, grupo de Teatro Clássico de Conimbriga 


\section{ENCONTROS DE TEATRO DE TEMA CLASSICO CONIMBRIGA - AEMINIUM - SELLIUM Maio a Outubro de 1999}

DIDO \& AENEAS de H. Purcell - Conservatório de Música de Coimbra

Conimbriga, 22 de Maio às 19 horas

SAMIA de Menandro - Grupo Selene de Madrid

Pátio da Universidade, 26 de Junho às $21: 30$ horas

Conimbriga, 27 de Junho às 18 horas

O EPIDICO de Plauto - Grupo Thiasos de Coimbra

Conimbriga, 18 de Julho às 18 horas

Museu Machado de Castro, 22 de Julho as $21: 30$ horas

Cidade de Tomar, 1 de Agosto

OS PERSAS de Ésquilo - Grupo A Escola da Noite de Coimbra

Conimbriga, 24 e 25 de Julho às 18 horas

1999

2000

2001

2002

MITOS CLÁSSICOS NA POESIA PORTUGUESA CONTEMPORÂNEA

- Grupo Teatro Clássico de Conimbriga

Pátio da Universidade, 31 de Julho às $21: 30$ horas

Cidade de Tomar, 8 de Agosto

Conimbriqa. 4 e 18 de Setembro às 18 horas

Museu Machado de Castro, 30 de Setembro às 21:30 horas

VIRIATO de J. Aguiar - Grupo Fatias de Cá de Tomar

Conimbriga, 22 de Agosto; 5 e 19 de Setembro às 18 horas

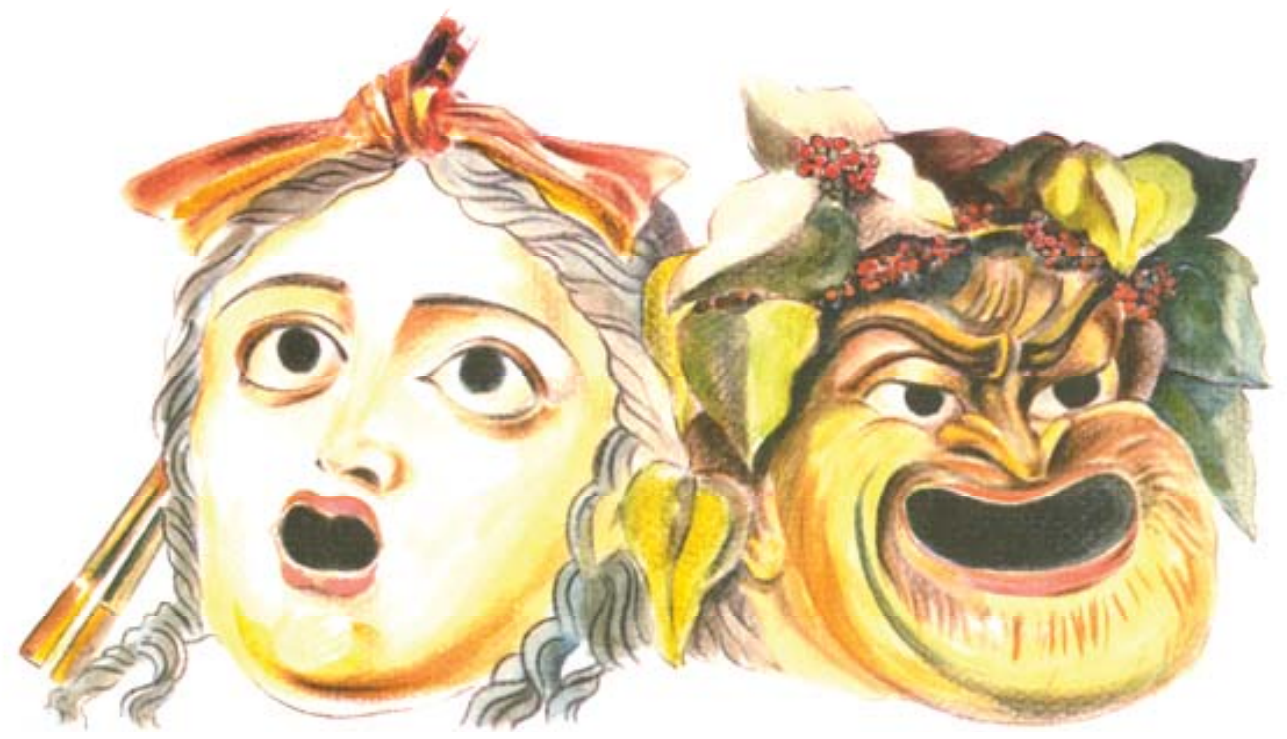

2003

2004

2005

2006
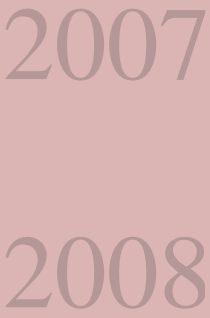


\section{Dido \& Eneias de H. Purcell \\ Grupo Canto e Drama \\ Conservatório de Música de Coimbra}

Direcção e orientação artística

Isabel Melo e Silva

Direcção do coro

Isilda Margarida

Acompanhamento ao piano Júlio Dias

Concepção e execução de figurinos

Ruy Malheiro

Assistência de figurinos

Catarina Braga, Mariana Abrunheiro

Produção / Grafismo / Programa

Mariana Abrunheiro, Catarina Braga

Elenco

Lara Martins (Dido)

João de Morais Fernandes (Eneias)

Maria do Castelo Gouveia (Belinda)

Ana Carina Reis (Segunda Mulher)

Catarina Braga (Feiticeira)

Ana Sofia Domingues, Mariana Abrunheiro

(Bruxas)

Mariana Abrunheira (Espírito)

\section{Sopranos}

Ana Carina Reis, Catarina Braga, Maria do Castelo, Mónica Baptista,

Sara Martins, Sandra Lopes

\section{Contraltos}

Ana Isabel Mendes, Ana Sofia Domingues,

Carlos Manuel Pocinho, Catarina Sereno,

Raul Campos, Maria Dulce Freitas, Mariana

Abrunheiro, Raquel Luís

\section{Tenores}

Eduardo Alves, Henrique Guerra,

Humberto Teixeira, João de Morais Fernandes,

Moisés Fonseca, Nuno Correia,

Paulo Alexandre Fernandes, Rui Costeira

\section{Baixos}

João Lopes, Isa Freitas, Mário Miguel Morais,

Nuno Miguel Araújo, Rui Pedro Cruz
Dido e Eneias foi composta por Henry Purcell, com libreto de Nahum Tate, a partir de um episódio da Eneida, de Virgílio. A ópera divide-se em três actos, sendo o segundo formado por duas cenas. É considerada, por uma grande parte de historiadores musicais, a primeira ópera inglesa, havendo, no entanto, a teoria sustentada por alguns musicólogos, de que se trata de uma "masque" (semi-ópera, subgénero semi-operístico), infinitamente mais desenvolvida e inspirada do que as habituais, sendo única dentro do panorama operístico internacional. De facto, existe apenas uma composição semelhante, Vénus e Adónis, de John Blow, em cujo modelo Purcell se pôde basear. Dido e Eneias é um caso isolado na produção de Purcell, uma vez que, em 1690 (um ano depois da estreia no Colégio Interno para raparigas de Josias Prest, Londres), começou a colaborar com os teatros públicos londrinos, escrevendo semi-óperas ("masques”) no seu sentido mais ou menos tradicional e afastando-se definitivamente da ópera.

Dido, rainha de Cartago, mostra-se relutante em declarar o seu amor ao Príncipe Eneias, um fugitivo da destruição de Tróia. A sua irmã Belinda e a sua corte incentivam-na a avançar e, quando Eneias apresenta um pedido de casamento, Dido aceita, para regozijo de todos. No entanto, bruxas malévolas planeiam a desordem, levantam uma tempestade e enviam a Eneias um duende disfarçado de Mercúrio, relembrando-o de que deve seguir o seu caminho até Itália. Para grande satisfação das bruxas, Eneias segue o conselho e deixa Cartago. Desolada pela traição de Eneias, Dido despede-se da vida.

Adaptado do Programa 


\section{Ópera em ambiente romano}

O ambiente romano do pátio interior do

Museu de

Conimbriga fol o

palco ideal, no sábado, para o grupo "O Canto e o Drama", do Conservatório de Música de Coimbra, fazer a sua estreia na ópera

obra "Dido \&
Eneias", de Henry

poema êpico "Eneida", que ao norte de Äfrica, junto de Vergilio escreveu a pedido Cartago. Ai, depois de cair do imperador Augusto, de amores pela rainha Dido, encaixa perfeitamente no a história prossegue até local. pois retrata uma chegar à regiâo do Lácio, época e um local que não onde formou uma colónia deverão ser muito diferentes romana.

da antiga cidade de Ópera que se preze tem Conimbriga.

A epopeia retrata a nâo foge à regra, pois Eneias história do jovem romano e Dido morrem de forma Eneias, que regressava a trágica.

Roma após a tomada de Nove estudantes do conTróia. Uma violenta tempes- servatório, dirigidos por tade dispersa a frota Isabel Melo e Silva, protagromana tendo o barco do onizaram esta ópera, apoiaherói de Vergilio ido parar dos por um pequeno coro.

\section{Purcell, baseada no}

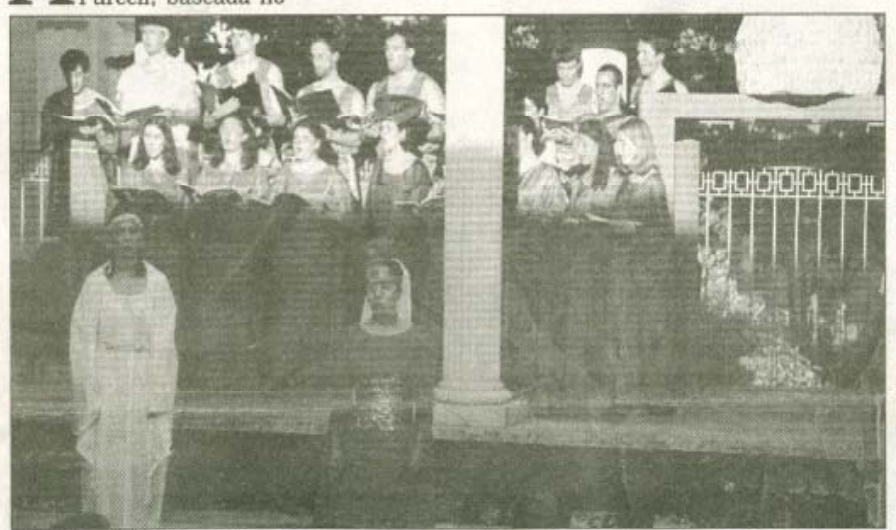

Os figurinos ficaram a cargo de Ruy Malheiro. Pormenor curioso foi o acompanhamento musical, pois no lugar da habitual orquestra apenas se fez ouvir o piano de Júlio Dias.

A representação de sábado marcou o inicio do programa "Encontros de Teatro Clássico", que dura até Outubro.

José Carlos Salgueiro

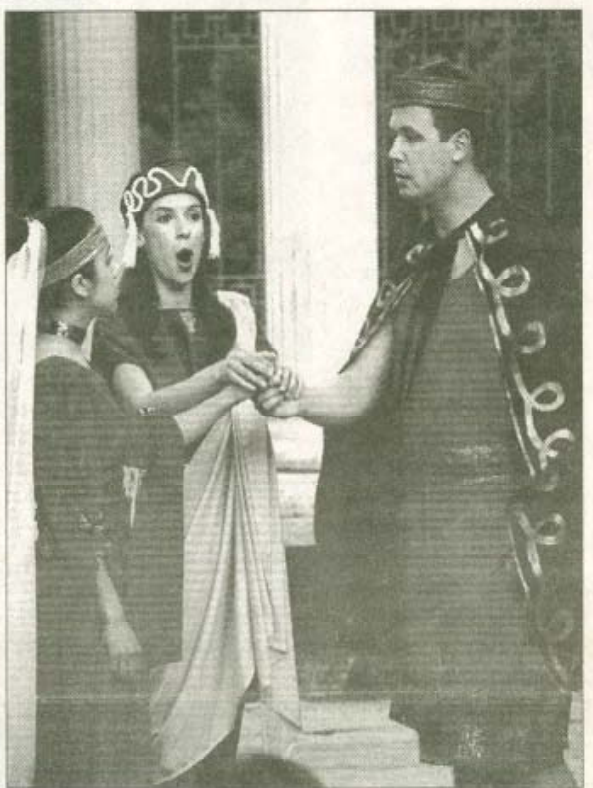

Eneias encontra Dido após uma tempestade o ter empurrado para Cartago
Diário de Coimbra

(24 de Maio de 1999) Texto e fotos de José Carlos Salgueiro

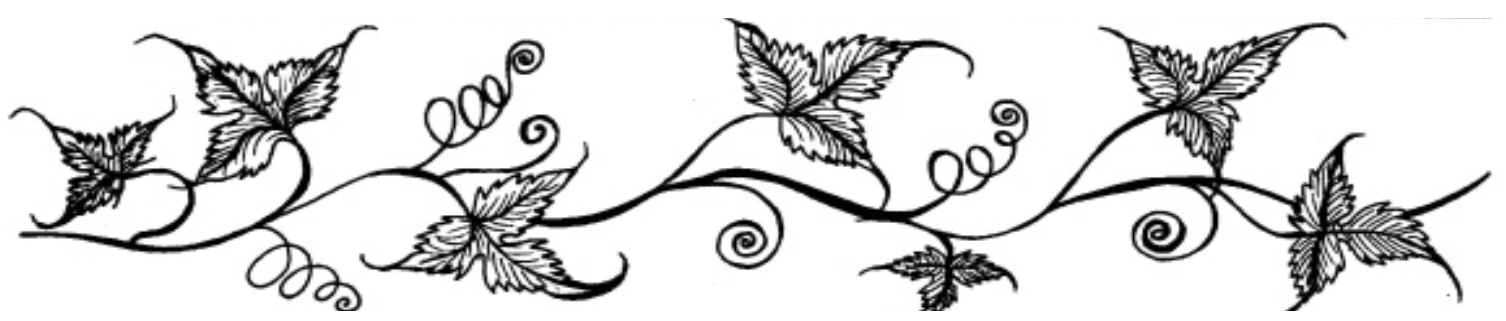




\section{Samia (A rapariga de Samos) de Menandro \\ Grupo Hélios de Madrid}

\author{
Tradução \\ José Luis Navarro \\ Encenação \\ José Luis Navarro, Gemma López \\ Coreografia \\ Ioannis Fousianis \\ Figurinos \\ Gemma López Martínez \\ Confecção do vestuário \\ La Soleá \\ Decoração e adereços \\ Jesús López Salinero \\ Iluminação e som \\ Carlos Guitart \\ Fotografia \\ Ángel Martínez
}

Elenco

Miguel Ángel Navarro, Javier García,

Antonia Paso (Démea)

Javier Valverde (Mósquion)

Laura Chica,

Maria del Mar Monserrate (Críside)

Javier Torrijos (Parmenão)

Rafael Esteban (Nicérato)

Abraham Company (Cozinheiro)

Ruth Rubio (Plângon)

Óscar García, Carlos Guitart

(Escravos de Démea)

\section{Coro}

Cristina Palomo (Corifeu), Amparo Torres, Cayetana Paso, Javier Torrijos, Ana García, Ruth Rubio, Cristina Sánchez, Héctor Bolanos
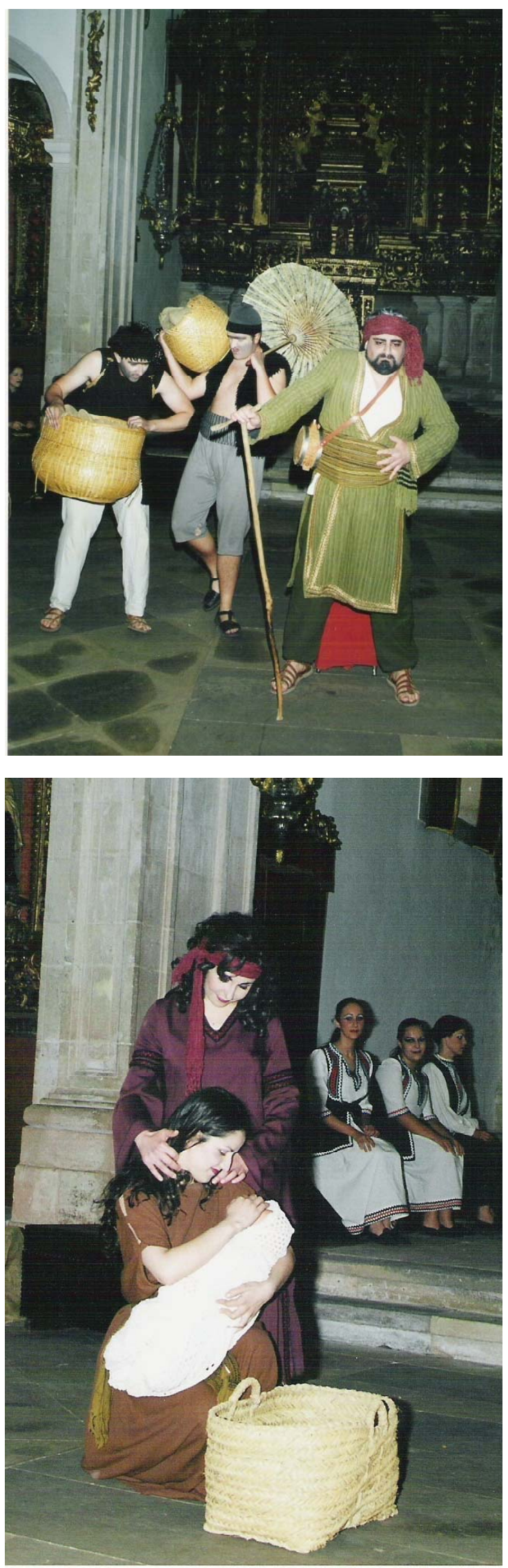
A história passa-se em Atenas, nos finais do séc. IV a.C. No cenário avistamos o interior de duas casas: uma humilde, pertence a Nicérato; a outra, mais brilhante e decorada, é propriedade de Démea. São ambos amigos e no início da comédia encontram-se a passar férias no Ponto. A sua entrada em cena constitui um dos momentos mais cómicos do espectáculo, com os "recuerdos" e o cansaço bem visível dos turistas, as queixas dos escravos e as exigências do velho rico, que até tem direito a um banho de pés que fica a meio. Na sua ausência, o filho adoptivo de Démea, Mósquion, engravidou Plângon, filha legítima de Nicérato. Para evitarem a ira dos pais, os jovens entregam a criança a Críside, a mulher de Samos, por quem
Démea morre de amores e com quem vive. Esta situação gera grandes confusões, primeiro na casa de Démea, depois na de Nicérato, mas, no final, tudo se resolve, e a peça termina com um faustoso banquete e uma belíssima festa de casamento.

Luísa de Nazaré Ferreira in Humanitas 51 (1999) 381-382.

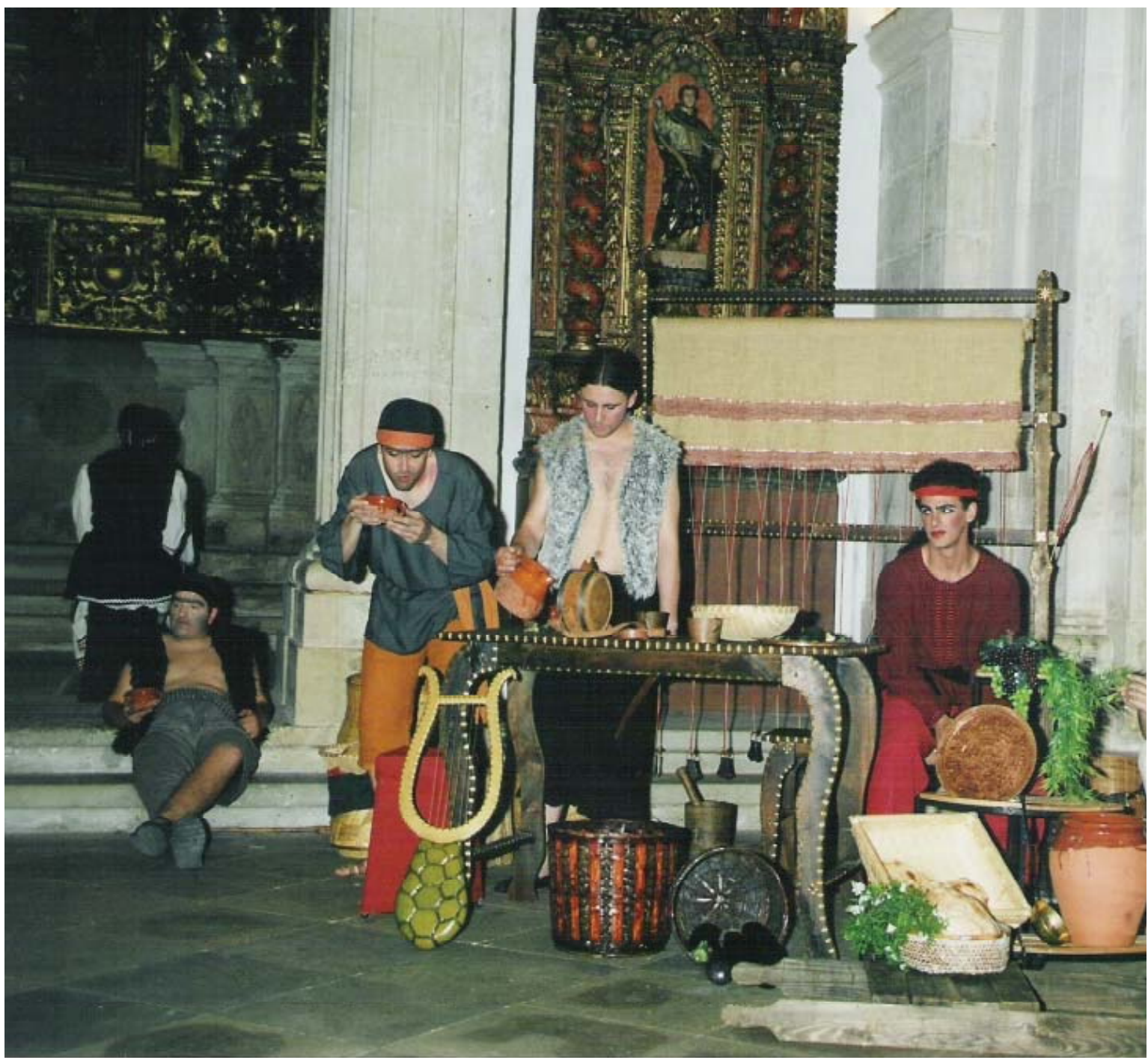

Samia de Menandro Museu Nacional Machado de Castro Fotos de José Batista 


\section{Epídico de Plauto}

Grupo Thíasos do IEC

\author{
Tradução \\ Walter S. Medeiros \\ Encenação \\ Paulo Sérgio Ferreira \\ Guarda-roupa
}

Luísa de Nazaré Ferreira,

Catarina Ferreira, Maria Manuela Silva

Contra-regra

Alessandra Oliveira

Luz

Pedro Santos, Ilídio Cadime

Som

Nuno Caldeira, José Luís Coelho,

Paulo Mota Gaspar, Paulo Sérgio Ferreira,

Nuno Gertrudes

Maquilhagem

Alexandra Santos, Patrícia Nunes

\section{Elenco}

Rui Henriques (Epídico)

Bento Silva (Tesprião)

Paulo Mota Gaspar (Estratípocles)

José Luís Coelho (Queribulo)

Delfim Ferreira Leão (Apécides)

José Luís Brandão (Perífanes)

Patrícia Nunes (Lirista anónima)

Nuno Gertrudes (Soldado fanfarrão)

Patrícia Santos (Filipa)

Alexandra Santos (Acropolístis)

Nuno Filipe José (Onzeneiro)

Mariana Matias (Teléstis)

Paulo Sérgio Ferreira

(Director da Companhia)

Bruno Lourenço (Escravo do Soldado)

Carla Brás (Cântara, escrava de Perífanes)
Diário As Beiras

(17 de Julho de 1999)

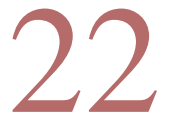

\section{Encontros de Teatro Clássico prosseguem com "Epídico"}

$\boldsymbol{r}$ L. P.

"Epídico" de Plauto é o espectáculo que prossegue amanhã e, depois, dia 22 e 1 de Agosto, o programa dos Encontros de Teatro de Tema Clássico com apresentaçôes em Conímbriga, no Museu Machado de Castro e em Tomar. No final do mês, o Grupo de Teatro Clássico de Conímbriga apresenta, em estreia, no Pátio da Universidade, o espectáculo "Mitos Clássicos na Poesia Portuguesa Contemporânea".

Embora já antes tivesse aprese itado outras peças, nomeada arente "0 Soldado Fanîtrāo", de Plauto, "As Mulheres no Parlamento", de Arístofanes, de que resultou um vídeo, e "O Auto da Alma", de Gil Vicente, o Tíasos - Grupo de Teatro do Instituto de Estudos Clássicos da Faculdade de Letras da Universidade de Coimbra apresentou-se a um público mais vasto com 0 "Epídico" em Abril de 1999.

Caracteristica fundamental do grupo, é a de aplicar a teoria que se pesquisa no Instituto de Estudos Clássicos, que o integra e financia "para ja", enquanto procura outros e novos apoios e termina os estatutos.

Quanto a "Epídico", as 15 personagens criadas por Plauto vão estar em cena a dar corpo e voz a um enredo complexo que, de acordo, com uma nota

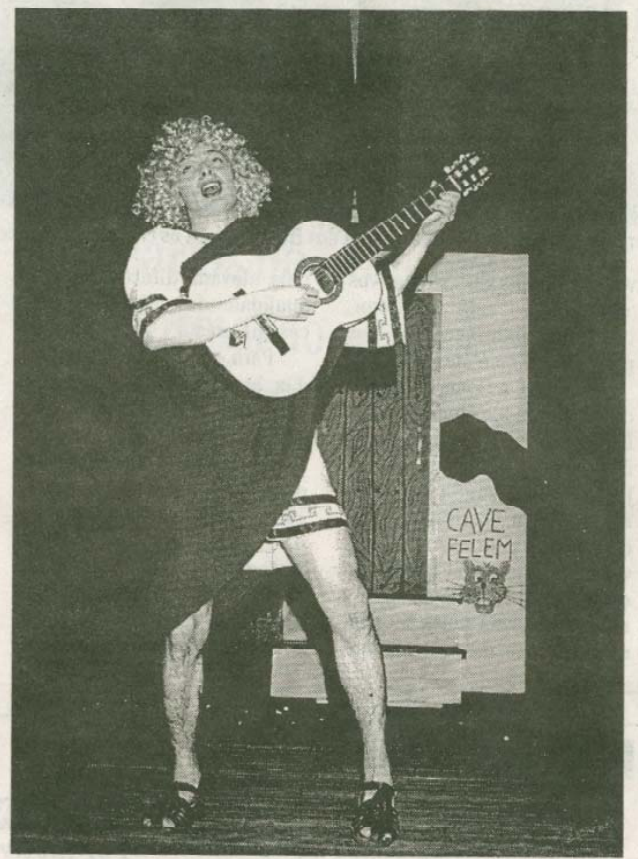

V "Epídico" é o espectáculo que marca encontro com o teatro clássico da produção começa assim: antes de partir para a guerra, dera Estratípoles ao seu escravo Epídico a incumbência de adquirir a lirista e cortesã Acropolistis, também cobiçada por que, lembrado de uns amores de juventude, começa a sentir remorsos do abandono da filha, fruto desses amores. E logo Epídico inventa tê-la encontrado, 0 que leva 0 velho a desembolsar as trinta minas necessárias à transaç̧ão. Assim, como filha, passa Acropolístis a viver em casa de Perífanes (...)

0 que depois se segue faz 0 Tíasos considerar "que a indife. rença, passados 22 séculos sobre a composição de Epídico, seria 0 maior atentado à memória de Plauto".

Com traducão de Walter de Sousa Medeiros e encenaçẫo de Sérgio Ferreira, guarda-roupa de Luisa de Nazaré Ferreira com a colaboracão de Catarina Ferreira e Maria Manuela Silva, luz de Pedro Santos e Ilídio Cadime, som de Nuno Caldeira, José Luís Coelho, Paulo Mota, Sérgio Ferreira e Nuno Gertrudes, cenário conjunto da equipa de actores, técnica e de Alexandrina Lourenço e maquilhagem de Alexandra Santos e Pa. trícia Nunes.

A apresentar amanhã, às $18 \mathrm{H} 00$, no forum das ruínas romanas de Conímbriga (local normalmente vedado à entrada de público, o que traz um interesse suplementar à apresenta(ção), "Epídico" volta à cena no dia 22, quinta-feira, no Museu Machado de Castro, e dia 1 de Agosto na cidade de Tomar. 


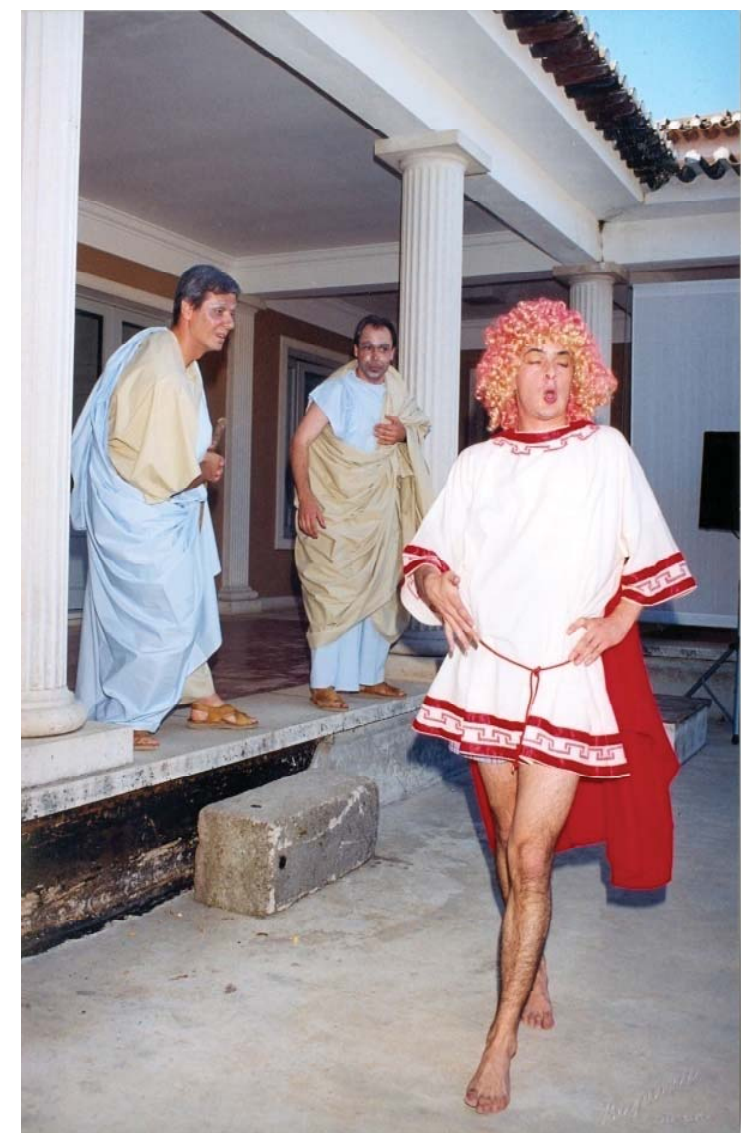

Estratípocles vai para a guerra e encomenda ao seu escravo Epídico a aquisição da amante, Acropolístis. Para conseguir tal objectivo, Epídico tem de recorrer a um expediente, porque o seu amo não lhe deixa nem meia moeda para a transacção. Convence então Perífanes, o pai do rapaz, a acolher em sua casa a jovem, dizendo-lhe que se trata da filha de um antigo amor dele... Entretanto, em Tebas, Estratípocles apaixona-se por uma cativa e endivida-se para a adquirir... Acropolístis já não lhe interessa. É esta a situação com que Epídico se defronta no próprio dia do regresso do jovem.

Começa assim esta deliciosa peça, de uma elegante e elaborada comicidade, que não recorre a processos de riso farsesco, antes assinala um momento de calculada sobriedade. O Epídico é uma comédia que o próprio Plauto - habituado a extrair do riso do público o sustento e a razão de ser da sua glória - amava tanto como a si mesmo.
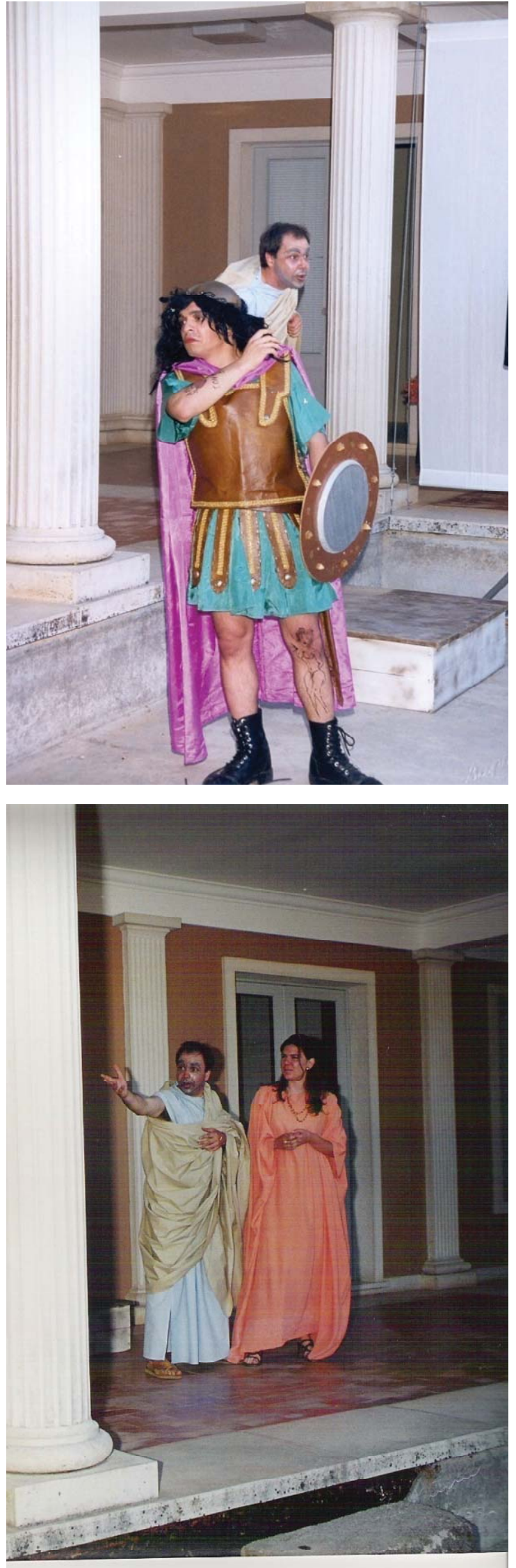

Epídico de Plauto

Museu Monográfico de Conimbriga

Fotos de José Batista

Walter S. Medeiros 


\section{Os Persas de Ésquilo}

A Escola da Noite

Tradução

Manuel de Oliveira Pulquério

Encenação e coreografia

Pierre Voltz

Adaptação dos coros

Mário Jorge Bonito

Figurinos

Rachid Dradar

Música

Lakis Karalis

Luzes

Mário Montenegro

Elenco

Mário Montenegro (Corifeu)

Sílvia Brito (Atossa)

António Jorge (Mensageiro)

Isabel Leitão (Dario)

Sofia Lobo (Xerxes)

\section{Coro}

Alexandre Ventura, João Saboga, Margarida Dias, Maria Simões, Pedro Laranjo,

Raul Rosário, Ricardo Silva, Ruy Malheiro

Aias

Elsa Rajado, Patrícia Simões

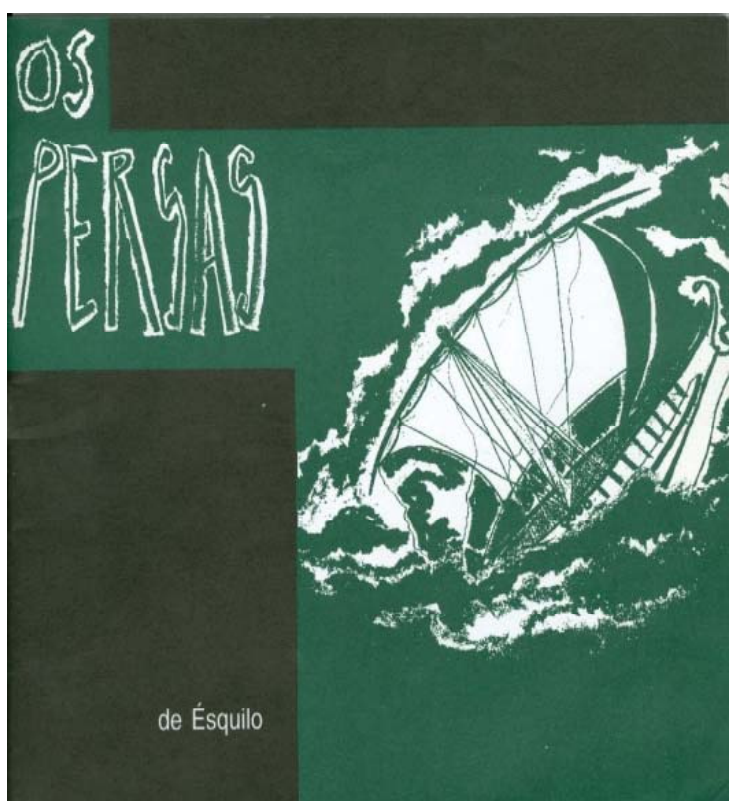

Levar à cena uma tragédia com a grandiosidade temática que têm Os Persas, ainda para mais sendo uma produção daquele que já entre os Antigos foi considerado o mais solene dos tragediógrafos e que é, simultaneamente, o primeiro exemplar do género chegado até nós praticamente inteiro, afigura-se-nos um projecto estimulante, mas, sem dúvida, arrojado. O teatro português não goza, ainda, de uma tradição de drama clássico suficientemente enraizada, de modo a facilitar a tarefa aos actores e encenadores que enveredem por caminhos desta natureza. Pelo que nos parecem bastante frutíferos os contactos ou colaborações que surjam com especialistas de países já com longa experiência na área. A participação de um grego neste espectáculo da Escola da Noite foi, sem dúvida, um trunfo bem aproveitado. Lakis Karalis, habituado a montar na Grécia a tragédia nas versões em grego antigo, cantadas sobre músicas bizantinas, nutriu o espectáculo dos seus tons, se não originais, pelo menos pátrios. Ensinados por ele, os actores intercalaram as partes líricas do coro, com o discurso da tradução portuguesa da autoria do Professor M. Oliveira Pulquério tiradas em idioma heleno. A emoção que geralmente transpira das intervenções corais viu-se, assim, largamente ampliada. Subrepticiamente acentuava-se, aos ouvidos de um público estrangeiro, um dos filões temáticos essenciais na peça: o exotismo do Bárbaro. Numa peça cuja história representada decorre em Susa, capital da Pérsia, de onde são naturais todas as personagens, espera-se que os figurinos e o desempenho cénico dos actores seja condizente com a cultura oriental. Louve-se, neste ponto, uma vez mais a sensatez do encenador, Pierre Voltz, que confessa no programa do espectáculo que, embora não pretenda retratar os Persas antigos, quis preservar o ambiente oriental da tragédia. Para tal contou com o apoio de Rachid Dradar, de origem marroquina, para a execução dos trajes. As túnicas do coro de Anciãos, de onde se destacava o corte mais solene do traje do Corifeu, e as cores fortes do vestido e turbante da rainha Atossa conferem ao quadro 
a tranquilidade hierática dos tons claros (bege e rosa pálido), raiada pelo fogo e vigor dos vermelhos, laranjas e castanhos.

Uma palavra de destaque cabe a algumas soluções cénicas interessantes: a disposição do público em anfiteatro à direita e esquerda do "palco" - situado ao nível térreo - bem como a ocupação de alguns lugares da primeira fila de ambos os lados por coreutas permitiu recriar a impressão de uma verdadeira assembleia da corte persa, que o espectador integra naturalmente; em um dos topos da sala foi colocado um estrado com vários níveis, local privilegiado para as movimentações dos soberanos da corte, Atossa e Xerxes, acompanhados de alguns serviçais; no outro, resguardada por um jogo de luzes mais tenebrosas, erguia-se uma tenda de forma estranha e incomodativa, cuja função acaba por ser revelada, quando, do seu interior, surge a surpreendente aparição do fantasma de Dario (cujo rosto pintado de branco e as vestes roxas enquadram a lividez e as ténebras próprias dos espectros do Além).
Numa peça em que o Coro tem um papel constante e serve de factor de coesão a todo o drama, era necessário apostar num desempenho nobre e convincente dos actores que vestiam a sua pele. Essa foi, definitivamente, uma aposta ganha. Assim como ao Mensageiro, intérprete da longa rhesis em que se dá conta da derrota do Bárbaro em Salamina, era exigida uma capacidade de envolvimento do público com o narrado tanto mais aguda quanto os quadros descritos eram todos de natureza extracénica. Apenas as figuras deAtossa, com os seus retoques maneiristas, e de Xerxes, de uma debilidade um tanto efeminada, nos pareceram fugir um pouco ao espírito da tragédia esquiliana.

Não obstante os pequenos "efeitos de estranhamento" de casos pontuais, plenamente justificáveis pelo carácter subjectivo de toda a obra de arte, a encenação de Os Persas pela Escola da Noite fez jus ao mérito que desde a Antiguidade lhe tem sido reconhecido.

Carmen Leal Soares, in Boletim de Estudos Clássicos 31 (Junho de 1999) 170-173.

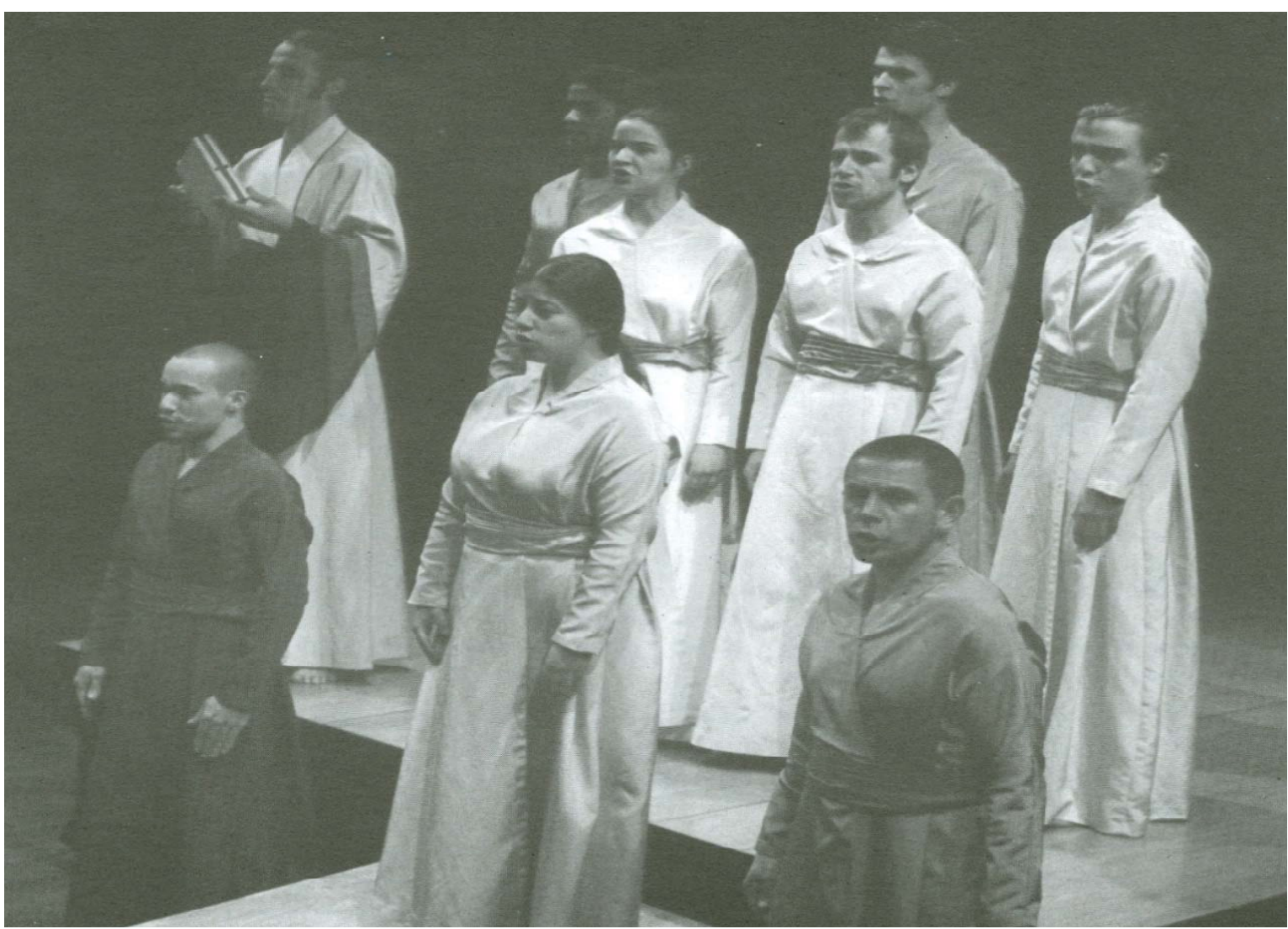

Fotografia de ensaio de Augusto Baptista

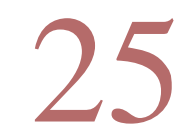




\section{Mitos Clássicos na Poesia \\ Portuguesa Contemporânea}

Grupo de Teatro Clássico de Conimbriga

\author{
Antologia \\ José Ribeiro Ferreira \\ Encenação e dramaturgia \\ José Geraldo \\ Figurinos e assistência de encenação \\ Joaquim Magalhães \\ Luzes e direcção técnica \\ José Geraldo, Rui Raposo \\ Som \\ José Geraldo \\ Consultores científicos \\ Adília Alarcão, José Ribeiro Ferreira \\ Intérpretes \\ Helena Faria, Rosário Romão, \\ Victor Torres
}

Este espectáculo, encenado e dirigido por José Geraldo, teve como consultores científicos Adília Alarcão e José Ribeiro Ferreira, e apoia-se na selecção de textos de numerosos poetas contemporâneos efectuada por este professor. A assistência, numerosa e atenta, ouviu as palavras de autores tão diversos como António José Queirós, António Mega Ferreira, David Mourão-Ferreira, Eugénio de Andrade, Fernando Guimarães, Fiama Hasse Pais Brandão, Helder Macedo, Herberto Helder, João Maia, João Miguel Fernandes Jorge, José António Almeida, José Augusto Seabra, José Gomes Ferreira, Manuel Alegre, Manuel Pulquério, Miguel Torga, Natália Correia, Pedro Támen, Sebastião da Gama, Sophia de
Mello Breyner Andresen, Teresa Balté, Vasco Graça Moura e Vasco Miranda.

Com recursos cénicos mínimos, mas aproveitando de forma excelente a escadaria da Via Latina do Páteo da Universidade, o Grupo de Teatro Clássico de Conimbriga construiu um espectáculo de grande qualidade e beleza que vive, em grande parte, para além dos méritos da encenação, da interpretação notável de três actores - porque, como explica o encenador, três era o número de actores no teatro clássico - que aceitaram a tarefa de dramatizar textos de poetas portuguesescontemporâneos, consagradosacinco célebres mitos gregos: Apolo, Ulisses, Labirinto e Minotauro, Orfeu e Diónisos. “A representação procura ser estilizada, não naturalista ou realista, mas poética, simbólica na intenção de captar a essência da palavra.” - escreve José Geraldo nas suas "notas de encenação".

Este espectáculo é, assim, constituído por cinco partes de duração variável, anunciadas por uma voz-off que explicava, em traços gerais, os dados mais importantes de cada mito, e separadas entre si pela introdução de pequenas alterações no cenário e pela mudança de roupa. Um dos elementos-chave desta dramatização é, portanto, o vestuário vistoso e sugestivo, concebido por Joaquim Magalhães e Isilda Ferreira. Outro elemento essencial é a música e porque um dos objectivos deste trabalho é oferecer uma leitura actual do mundo antigo, os fragmentos de música utilizados pertencem intencionalmente a compositores da segunda metade do século XX: Glen Velez, Harry Partch, Henry Cowell, Iannis Xenakis, Lou Harrison, Mark Anthony Turnage, Igor Stravinsky, Carl Orff e The Grief.

Luísa de Nazaré Ferreira, in Humanitas 51 (1999) 383-384.

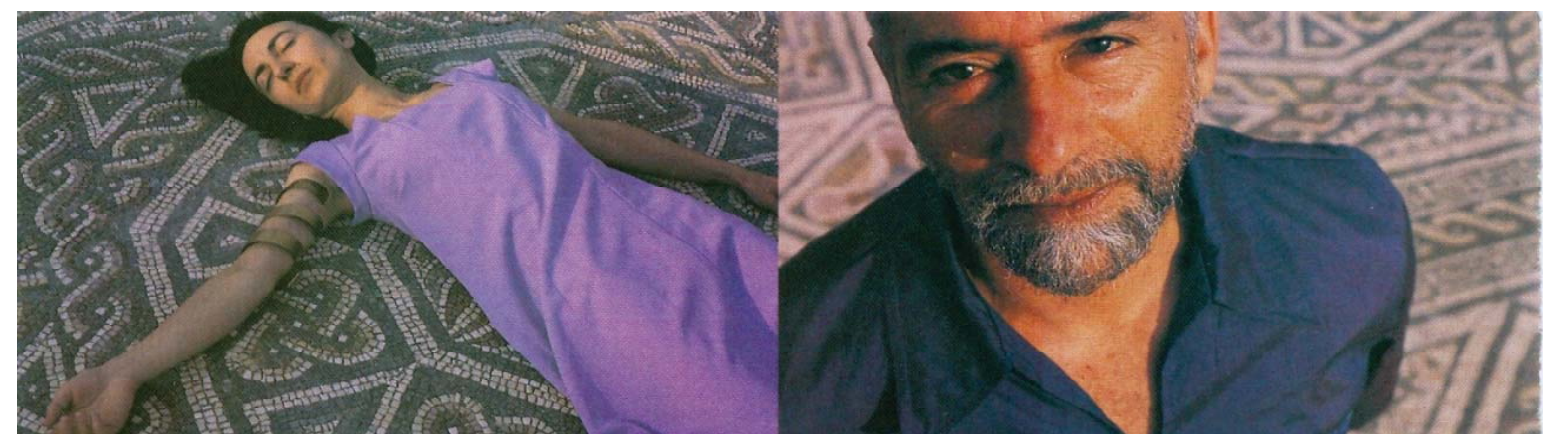




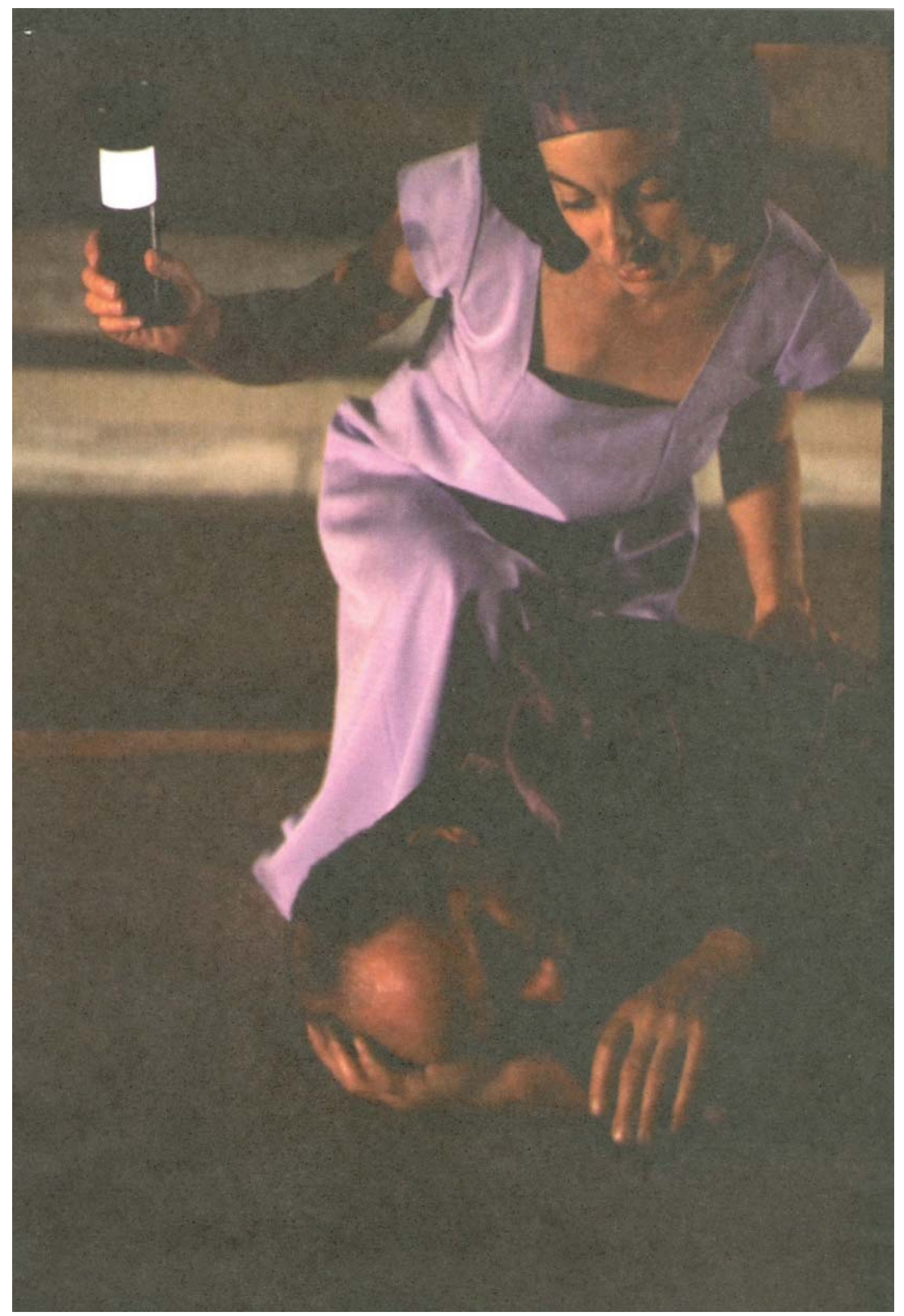




\section{Viriato de João Aguiar}

Grupo Fatias de Cá de Tomar

\author{
Encenação \\ Carlos Carvalheiro
}

A acção da peça decorre no ano de 147 a.C., quando os Romanos de novo investiam contra guerreiros lusitanos, chefiados por Viriato, no que parecia ser simplesmente mais uma campanha contra os resistentes da Ibéria. Uma surpresa lhes estava, no entanto, reservada. Até ser assassinado em 139 a.C., Viriato desenvolveu, com clarividência política e militar, um processo de resistência incansável contra o poderio romano, em que radicam características profundas da identidade ibérica.

Formado por um misto de amadores e profissionais, o grupo de teatro Fatias de Cá vem desenvolvendo, desde 1979, uma enérgica actividade dramática na sua cidade de origem, Tomar. Com esta adaptação do texto de João Aguiar, ensaiou-se uma encenação original que teve, no espectáculo de estreia, por pano de fundo o Castelo de Almourol, um espaço que, com o enquadramento da serra de Sicó, tinha todo o poder sugestivo da paisagem agreste de um campo de batalha. A hora a que decorreu o espectáculo permitiu também que ele começasse com sol, que entretanto se vai pondo para dar lugar à lua e permitir efeitos especiais à luz dos archotes. A presença dos cavalos acrescenta um último retoque a um ambiente que se pretende sugestivo das cavas onde o guerreiro organizou a sua resistência. O espectáculo resulta da articulação entre o texto de João Aguiar, lido em voz off, e todo um movimento cénico em que se impõem os jogos marciais, desfiles militares, conselhos de guerra, além dos ritos matrimoniais de Viriato. Para melhor envolver o público, um intervalo permitiu que os espectadores pudessem participar da boda e saborear uma ementa constituída por pão, água, carne assada e frutas. Na segunda parte, representada já com noite profunda, multiplicam-se as batalhas e desenvolve-se uma rede de traições que levam à morte de Viriato. Toda esta espectacularidade e envolvimento da cena, o espaço natural, de um elenco que mobilizou mais de 50 actores em palco e do público, que não faltou, foram as grandes virtudes desta proposta teatral.

José Ribeiro Ferreira, in Maria de Fátima Silva (coord.), Representações de Teatro Clássico no Portugal Contemporâneo I (Coimbra 1998) 140-141.

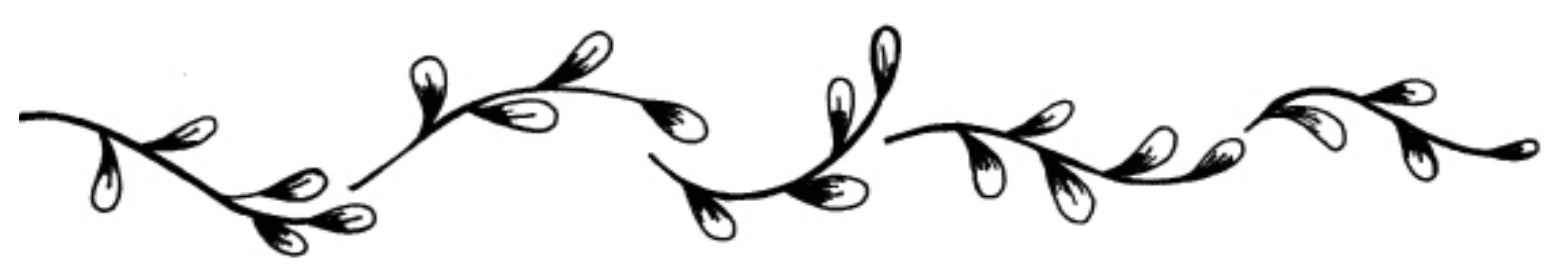




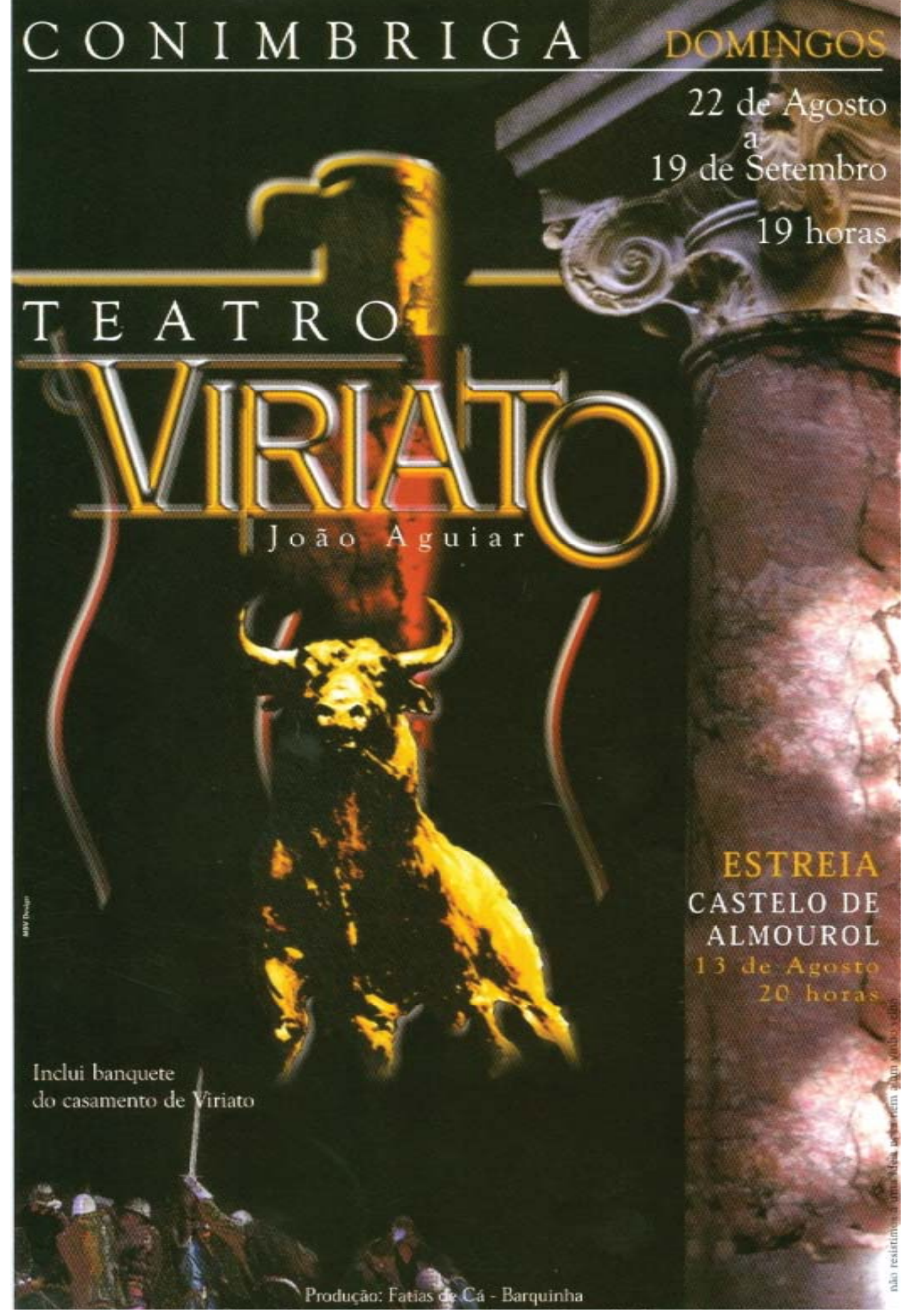

29 


\section{ENCONTROS DE VERÃO \\ DE TEATRO DE TEMA CLÁSSICO}

4 de Junho de 2000, 16.00 horas, Conimbriga

Comédia da Marmita de Plauto, grupo Fatias de Cá de Tomar

24 de Junho de 2000, 16.30 horas, Conimbriga

Epídico de Plauto, grupo Thíasos do IEC

24 de Junho de 2000, 21.30 horas, Páteo da Universidade de Coimbra

Andrómaca de Eurípides, grupo Selene do IES Carlos III de Madrid

25 de Junho de 2000, 18.00 horas, Museu Grão-Vasco (Viseu)

Andrómaca de Eurípides, grupo Selene do IES Carlos III de Madrid

1 de Julho de 2000, 21.30 horas, Praça 8 de Maio (Coimbra)

Epídico de Plauto, grupo Thíasos do IEC

2 de Julho de 2000, 16.00 horas, Conimbriga

Comédia da Marmita de Plauto, grupo Fatias de Cá de Tomar

2 de Julho de 2000, 21.30 horas, Museu Grão-Vasco (Viseu)

Epídico de Plauto, grupo Thíasos do IEC

6 de Julho de 2000, 21.00 horas, Museu Nacional Machado de Castro

As Troianas de Eurípides, grupo Balbo do IES de Puerto de Santa María (Cádis)

7 de Julho de 2000, 21.30 horas, Páteo da Universidade de Coimbra

As Troianas de Eurípides, grupo Balbo do IES de Puerto de Santa María (Cádis)

8 de Julho de 2000, 21.30 horas, Conimbriga

Gorgulho de Plauto, grupo Balbo do IES de Puerto de Santa María (Cádis)

9 de Julho de 2000, 21.00 horas, Termas Romanas de Braga

Gorgulho de Plauto, grupo Balbo do IES de Puerto de Santa María (Cádis)

11 de Julho de 2000, 16.30 horas, Conimbriga

Soldado Fanfarrão de Plauto, grupo de Teatro da Escola Secundária de Cantanhede

6 de Agosto de 2000, 16.00 horas, Conimbriga

Comédia da Marmita de Plauto, grupo Fatias de Cá de Tomar

3 de Setembro de 2000, 16.00 horas, Conimbriga

Comédia da Marmita de Plauto, grupo Fatias de Cá de Tomar

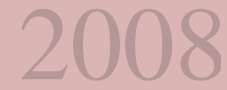




\section{Andrómaca de Eurípides}

Grupo Selene do IES Carlos III de Madrid

Tradução
José Luis Navarro
Encenação
José Luis Navarro, Gemma López
Coreografia e figurinos
Gemma López
Luzes e som
Carlos Guitart
Alvaro Bibiano
Maquilhagem
Mireya Alirangues
Helena del Río
Elenco
Amparo Torres (Andrómaca)
Laura Chica (Hermíone)
Javier Valverde (Peleu)

Miguel Angel Navarro, Javier García Penas (Menelau)

Javier Torrijos (Orestes)

Veronica Benito (Tétis)

Alexandra Córdoba, Susana Critóbal (Astíanax)

Cristina Sánchez (Mensageiro)

Sara Andrés (Ana)

Hector Bolanos (Soldado)

Mónica Casal, Andrea Cristóbal (Criados)

Iolanda Machío (Helena)

Fátima Mohamed (Primeira Serva)

Raquel Pino (Segunda Serva)

Marta Pérez Benito (Corifeu)

\section{Semicoro A}

Cintia Medina, Estefania Pérez,

Sara Dablanca, Ruth Rubio,

Ester Diaz, Noelia Mera

\section{Semicoro B}

Maria Méllen, Beatriz deI Castillo, Beatriz Magán, Laura Pascual, Laura López, Alejandra López-Moriarty

Andrómaca de Eurípides Museu Nacional Machado de Castro Fotos de José Batista
Por ocasião do I Congresso da Associação Portuguesa de Estudos Clássicos (APEC), decorrido entre os dias 4 e 6 de Junho de 1998 na Faculdade de Letras da Universidade de Coimbra, a Companhia de Teatro Grego Clássico "Selene" do Instituto de Bachillerato Carlos III de Madrid trouxe ao nosso país a representação de uma das tragédias euripidianas menos representadas na actualidade, a Andrómaca. A relativa pouca difusão da obra nos palcos modernos, cronologicamente tão distantes da data da sua aparição em Atenas no ano de 425 a.C., acabou por resultar num incentivo para a produção do grupo madrileno e num atractivo para o público, muito em especial o conhecedor do legado do drama grego antigo. A avaliação correcta dos factores determinantes do sucesso de um desafio desta natureza passa por uma breve análise do percurso diacrónico desta companhia académica.

De facto o motor principal dos projectos teatrais do Selene reside na inserção dos mesmos no programa curricular da disciplina de Grego oferecida aos alunos do Instituto de Bachillerato Carlos III.

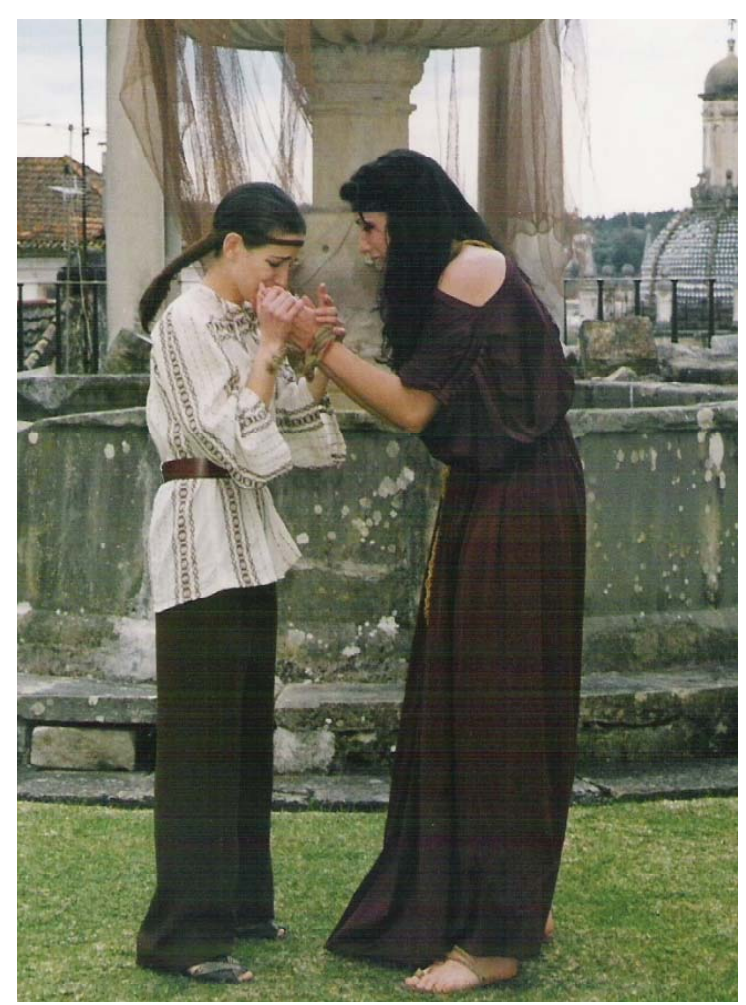


Fundado em 1981 pelo catedrátrico da cadeira, Prof. JoséLuis Navarro, ogrupo contava, em 1999, ao ritmo de uma produção por ano, com dezanove representações de textos gregos, onde, conforme seria de esperar, predominam as tragédias e comédias. O espectáculo trazido a Coimbra serviu para reforçar a ideia de que os bons resultados de um trabalho se devem à articulação entre teoria e prática.

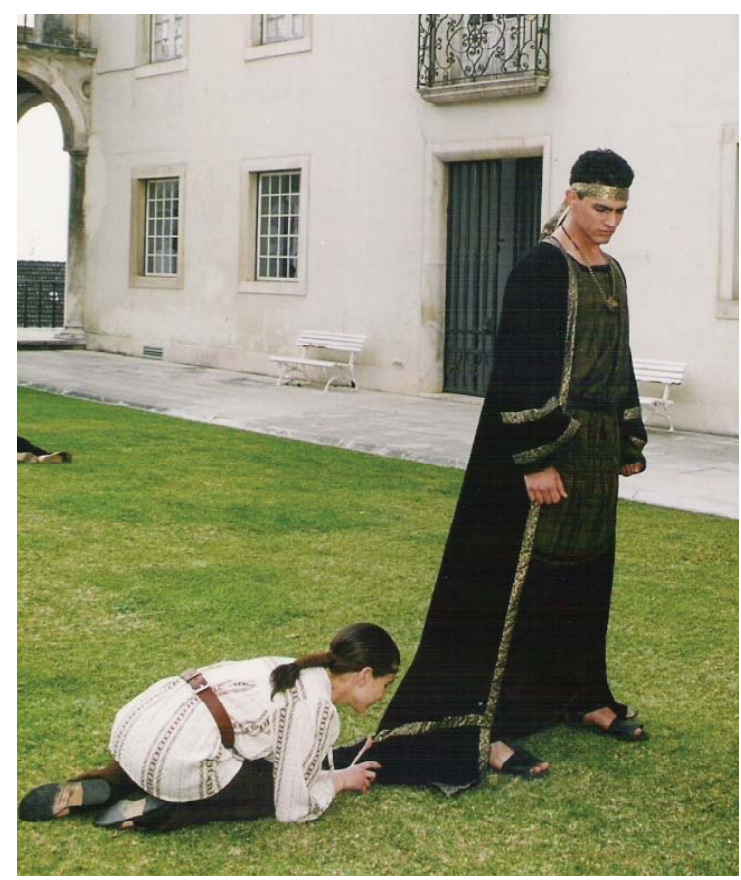

Aos conhecimentos filológicos e literários inerentes ao ramo de saber em que investiga, José Luis Navarro alia uma formação pessoal na área das técnicas do drama antigo. No caso particular da Andrómaca, o vestuário foi desenhado a partir de um levantamento feito, consoante tem o cuidado de esclarecer no folheto do programa do espectáculo, “única e exclusivamente” na Grécia. Aproveitamos para destacar alguns dos aspectos que nos parecem mais relevantes do elevado nível conseguido por actores, não é demais lembrá-lo, amadores e ainda bastante jovens. O trabalho das vozes reflectiu a sobriedade exigida ao texto trágico e a coreografia revelou a vantagem de veicular a emotividade contida nas intervenções corais. Numa peça em que - ao contrário de outras como as esquilianas Persas e Euménides ou as euripidianas Suplicantes e As Troianas - a relação do coro com o progresso da intriga é algo débil, o desenho da sua actuação em cena exige cuidados especiais, de modo a evitar a transformação da sua presença num adereço supérfluo. As danças geométricas das coreutas, desenhando círculos, semicírculos, cruzes em forma de aspas ou simples linhas rectas, surtiram um agradável efeito de harmonia. Mas é sobretudo no final da tragédia, quando o corpo de Neoptólemo é trazido para o palácio da Ftia, que a pujança emocional da presença das mulheres tessalas vestidas de negro atinge o clímax. Em marcha lenta, o cortejo fúnebre acompanha o príncipe jazente fazendo estalar a compasso duas correias que traz seguras nas duas extremidades. O local escolhido para a representação, a Igreja de S. João de Almedina no Museu Nacional Machado de Castro, proporcionou a acústica perfeita e contribuiu em muito para a comoção dos espectadores.

Carmen Leal Soares, in Maria de Fátima Silva (coord.), Representações de Teatro de Tema Clássico no Portugal Contemporâneo II (Coimbra 2001) 93-94. 


\section{O Gorgulho de Plauto}

Grupo Balbo do IES Santo Domingo de

Puerto de Santa María (Cádis)

\author{
Encenação \\ Emilio Flor Jiménez \\ Música \\ Raquel Zurdo \\ Vestuário \\ Javier Palacios \\ Coreografia \\ Raquel Zurdo \\ Percussão \\ Esteban Fernández Pedes \\ Elenco
}

Javier Palacios Camacho (Gorgulho)

Adrián Varo García, Miguel Astorga Hermida

(Fédromo)

Sergio Suárez López (Palinuro)

Elisa Marín Amor (Lena)

Nerea Miranda Ramírez (Planésio)

Rafael Franco Molina (Cápadox)

Victoria Viñas Cardona (Cozinheiro)

Ángel Fernández Gálvez (Licão)

Julia Monje Serrano (Terapontígono)

\section{Cortesãs}

Luisa Pinto Teyz, Patricia Buller, Irene Rodicio Cemadas, Raquel Zurdo, Charo Roselló

Macías, Rosa Díaz Cores, Fadoua Lazaghoui,

Elisa Marin Amor

\section{Mimos}

Victoria Viñas Cardona, Daniel Arenas Suárez, Valentín Murillo, Romero Marcos Collado Martín

Para libertar a amada Planésio das mãos do alcoviteiro Cápadox, o jovem Fédromo decidiu recorrer às pretensas posses de um amigo que vivia na Cária. Da missão encarregou o seu parasita, Gorgulho, que deu com um rapaz cheio de boa vontade, mas tão teso quanto o seu amo. Deparou ainda com Terapontígono, o miles gloriosus, que já tinha apalavrada a aquisição de Planésio. Em lauto repasto, regado com muito vinho, o parasita roubou o anel-sinete ao soldado e, no regresso a Epidauro, forjou uma carta autenticada para o banqueiro Licão, que desbloqueou as trinta minas que Terapontígono tinha depositado para a libertação de Planésio. Tudo parecia bem encaminhado, não fosse o miles, já em Epidauro, descobrir a tramóia de Gorgulho, que, de repente, se via em maus lençóis. A Sorte premiou a audácia do parasita: o anel levantou a suspeita, posteriormente confirmada pelas perguntas sobre a paternidade, de que Planésio era a irmã que Terapontígono tinha perdido durante um espectáculo das Dionísias. Dois jantares de festa e mesa sempre posta em casa de Planésio e de Fédromo constituíram o auge das recompensas recebidas por Gorgulho.

As personagens-tipo, os quiproquós, as cenas movimentadas, o cómico grosseiro, as patranhas, as quebras de ilusão cénica e o canto são alguns dos recursos de que Plauto lança mão, em $O$ Gorgulho, para divertir a plebe. Como no tempo de Plauto, também os jovens actores espanhóis improvisaram um pouco. No folheto que acompanhou as actuações, o Grupo Balbo lançou o seguinte repto ao público, maioritariamente jovem, que teve o privilégio de assistir a representações de tão grande qualidade: "Por tanto, solo pediremos que se sitúen entre las gradas de nuestro teatro y se dejen llevar por un grupo de jóvenes, hoy, pícaros, desvergonzados y vulgares actores, mafíana, sinceros, respetuosos y educados. Así que modifiquemos, por un instante, nuestros rostros y nuestra postura. Participemos en lo ridículo de la desvergüenza com un espíritu de Fiesta!”

Paulo Sérgio Ferreira, in Maria de Fátima Silva (coord.), Representações de Teatro de Tema Clássico no Portugal Contemporâneo II (Coimbra 2001) 320-322. 


\section{As Troianas de Eurípides}

Grupo Balbo do IES Santo Domingo de

Puerto de Santa María (Cádis)

\section{Encenação}

Emilio Flor Jiménez

\section{Luzes}

Joaco Arjona Cabrera

Som

Antonio Pecho Martín

\section{Elenco}

Eva Maria Rodríguez Cruz (Hécuba)

Francisco Javier Ortega Jaén (Taltíbio)

Patricia López Ocafia (Cassandra)

Esther Pumar Reyes (Andrómaca)

Marcos Collado Martín (Menelau)

Elisabeth Mena Linder (Helena)

\section{Coro}

Margarida Domínguez Sánchez (Corifeu), Elisabeth Mena Linder, Fátima Jiménez Enrique, Maria Serpa Mora, Regina Carballo López, Libertad Marín Rueda, Maria Reyes, Zoraida Valiente Rodríguez
Percorre As Troianas de Eurípides um pensamento anti-belicista, de solidariedade, de respeito pelas pessoas, acentuado nesta encenação. Quer dizer, transmite valores psicológicos e morais. Sobretudo procura exaltar os grandes sofrimentos que viveram, como já dizia Homero, "as mulheres de belas tranças".

Essas mulheres, viúvas ou filhas dos troianos mortos na guerra, aguardam para ver que destino as espera, quando a sua cidade está prestes a consumir-se nas chamas. Hécuba, a rainha-mãe, vai recebendo da boca do arauto grego Taltíbio as notícias do sorteio que acabam de efectuar os chefes do exército aqueu. E, a partir da primeira informação, Eurípides apresenta-nos uma dor que vai crescendo em intensidade e que se personifica na figura de Hécuba. Assim a anciã rainha vai saber que a sua filha Políxena será degolada como oferenda no túmulo de Aquiles; que Cassandra vai ser levada até

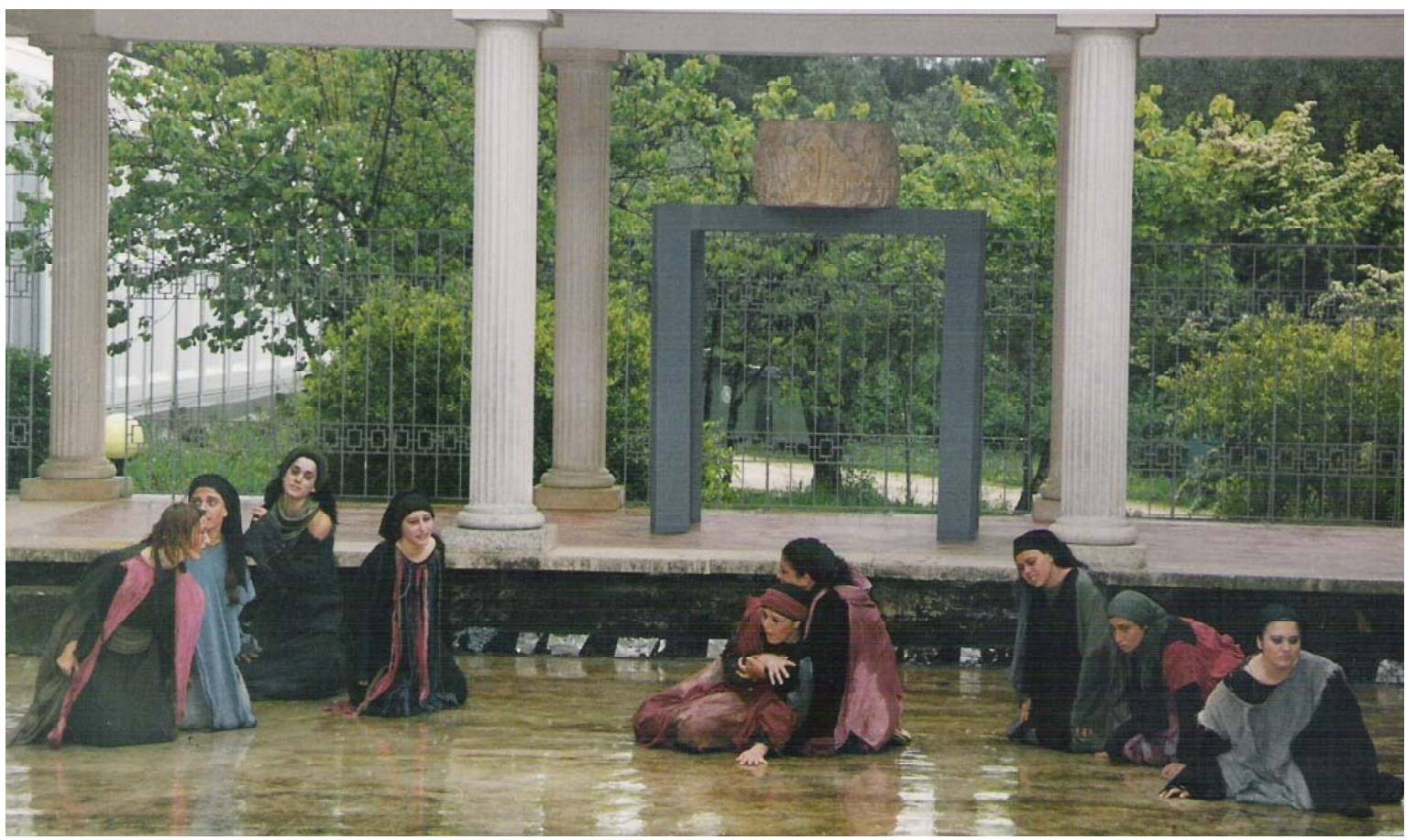

As Troianas de Eurípides Museu Monográfico de Conimbriga Fotos de José Batista 


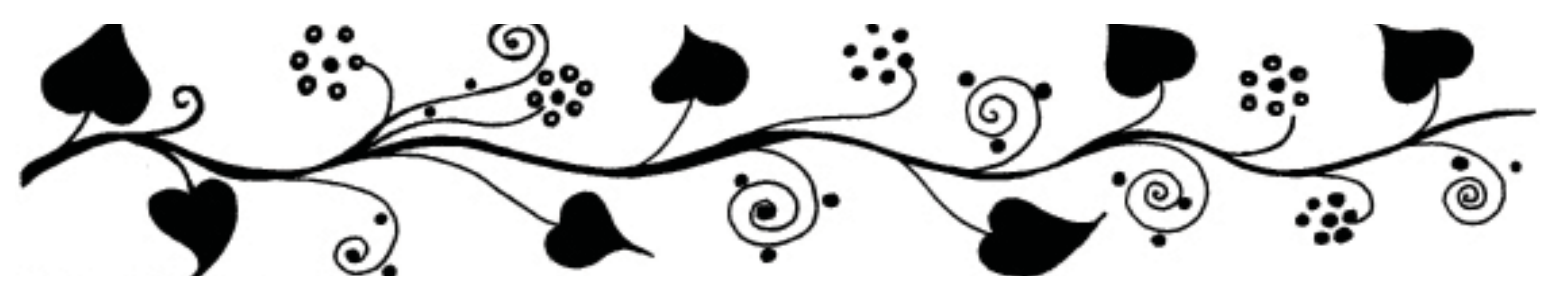

Micenas, onde a aguarda a morte, que ela própria profetisa; que Andrómaca - paradoxo do destino vai ser a companheira de leito de Neoptólemo, filho de Aquiles, o assassino de Heitor, seu legítimo marido. A dor de Hécuba atinge o paroxismo, quando Taltíbio chega de novo para levar a cabo a acção mais ignominiosa e impensável: o assassinato de Astíanax, o filho de Heitor, criança ainda, de uma forma especialmente brutal, despenhando-o das torres de Tróia. O lamento da rainha diante do infortunado cadáver do neto mistura-se, no final da obra, com o estrépito dos edifícios de Tróia que se desmoronam sem remédio, consumidos pelas chamas.

José Ribeiro Ferreira, in Maria de Fátima Silva (coord.), Representações de Teatro de Tema Clássico no Portugal Contemporâneo II (Coimbra 2001) 69-70.

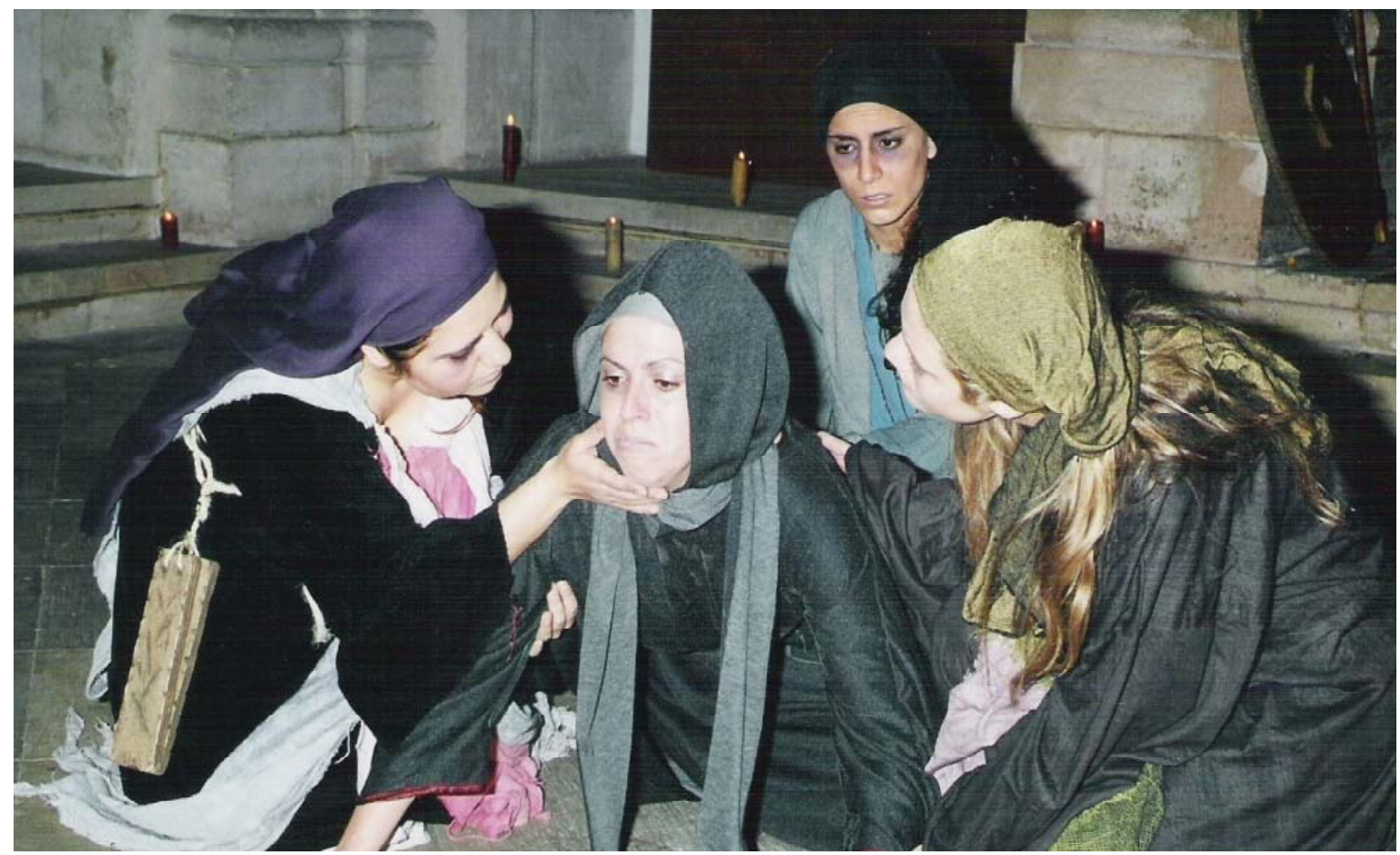




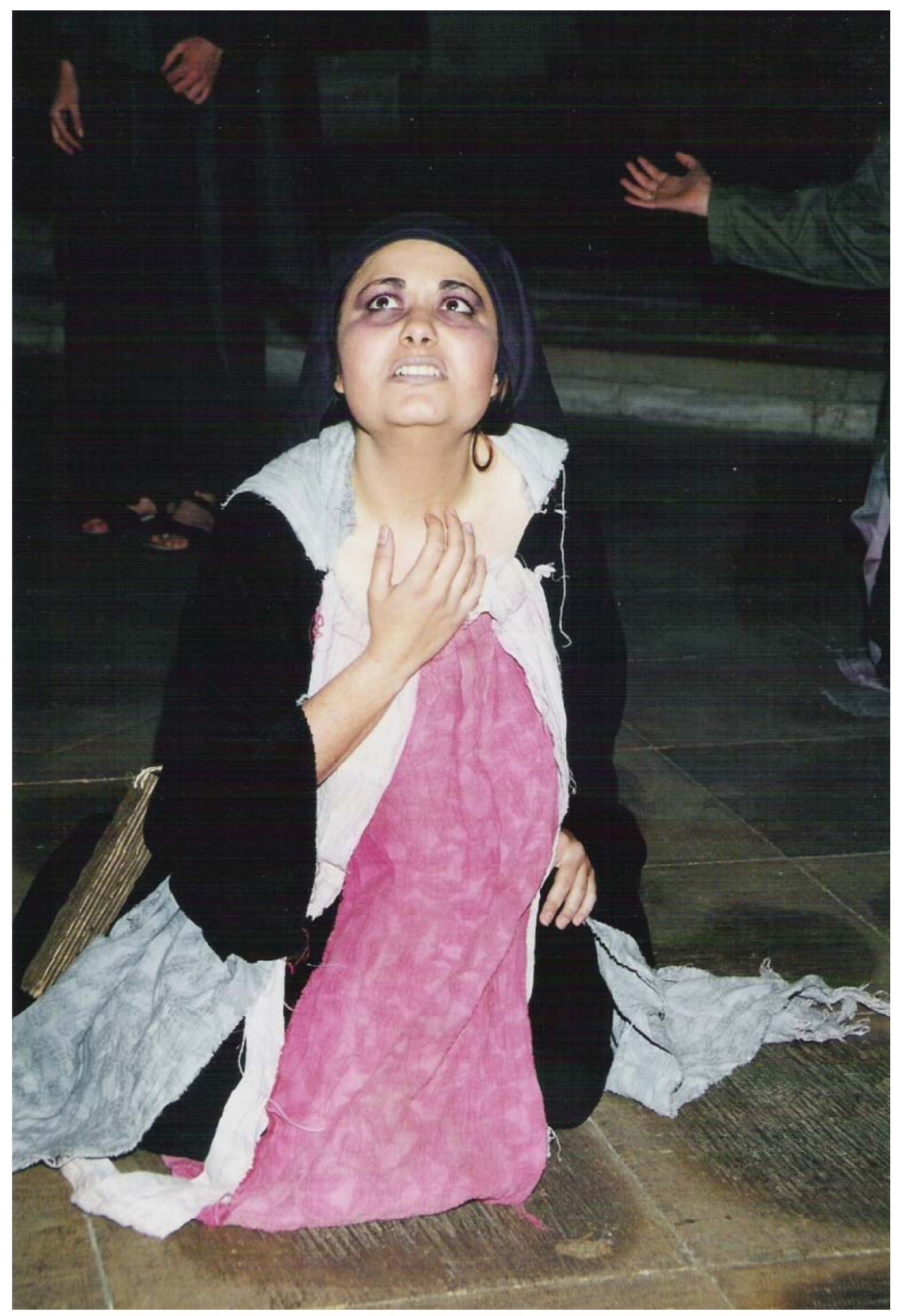

As Troianas

de Eurípides

Museu Nacional

Machado de Castro

Fotos de José Batista

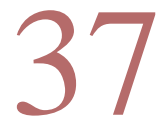


23 de Abril de 2001, 11.00 horas, Conimbriga Os Heraclidas de Eurípides, grupo Thíasos do IEC

23 de Abril de 2001, 15.30 horas, Conimbriga Mitos Clássicos na Poesia Portuguesa Contemporânea, grupo de Teatro Clássico de Conimbriga

23 de Abril de 2001, 15.30 horas, Museu Nacional Machado de Castro Orfeo ed Euridice de Gluck, grupo Canto e Drama do Conservatório de Música de Coimbra

24 de Abril de 2001, 11.00 horas, Conimbriga Mitos Clássicos na Poesia Portuguesa Contemporânea, grupo de Teatro Clássico de Conimbriga

24 de Abril de 2001, 15.30 horas, Museu Nacional Machado de Castro Os Heraclidas de Eurípides, grupo Thíasos do IEC

26 de Abril de 2001, 21.00 horas, Pólo de Viseu da Universidade Católica Mitos Clássicos na Poesia Portuguesa Contemporânea, grupo de Teatro Clássico de Conimbriga

27 de Abril de 2001, 11.00 horas, Conimbriga Comédia da Marmita de Plauto, grupo Balbo do IES de Puerto de Santa María (Cádis)

27 de Abril de 2001, 15.30 horas, Conimbriga Coéforas de Ésquilo, grupo Balbo do IES de Puerto de Santa María (Cádis)

30 de Abril de 2001, 10.00 horas, Museu Nacional Machado de Castro As Troianas de Eurípides, grupo Balbo do IES de Puerto de Santa María (Cádis)

30 de Abril de 2001, 15.30 horas, Convento de Cristo (Tomar) As Troianas de Eurípides, grupo Balbo do IES de Puerto de Santa María (Cádis)

2 de Maio de 2001, 11.00 horas, Museu Nacional Machado de Castro Édipo em Colono de Sófocles, grupo Hélios de Madrid

2 de Maio de 2001, 15.30 horas, Museu Nacional Machado de Castro Samia de Menandro, grupo Hélios de Madrid

3 de Maio de 2001, 11.00 horas, Conimbriga Mitos Clássicos na Poesia Portuguesa Contemporânea, grupo de Teatro Clássico de Conimbriga

18 de Maio de 2001, 11.00 horas, Conimbriga Os Heraclidas de Eurípides, grupo Thíasos do IEC

18 de Maio de 2001, 21.30 horas, Conimbriga Orfeu e Eurídice de Gluck, grupo Canto e Drama do Conservatório de Música de Coimbra 


\section{FESTIVAL DE VERÃO \\ DE TEATRO DE TEMA CLÁSSICO}

31 de Maio de 2001, 21.30 horas, Claustros de Santa Cruz (Coimbra)

Os Heraclidas de Eurípides, grupo Thíasos do IEC

1 de Junho de 2001, 19.30 horas, Museu da Citânia de Sanfins

Os Heraclidas de Eurípides, grupo Thíasos do IEC

2 de Junho de 2001, 21.30 horas, Páteo da Universidade de Coimbra

Íon de Eurípides, grupo Selene do IES Carlos III de Madrid

3 de Junho de 2001, 21.30 horas, Pátio do Palácio dos Figueiredos (Condeixa)

Íon de Eurípides, grupo Selene do IES Carlos III de Madrid

9 de Junho de 2001, 21.30 horas, Claustros do Seminário de Viseu

Os Heraclidas de Eurípides, grupo Thíasos do IEC

10 de Junho de 2001, 14.30 horas, Pátio do Palácio dos Figueiredos (Condeixa)

Mitos Clássicos na Poesia Portuguesa Contemporânea,

grupo de Teatro Clássico de Conimbriga

10 de Junho de 2001, 17.00 horas, Salão dos Bombeiros Voluntários de Condeixa

Comédia da Marmita de Plauto, grupo Balbo do IES de Puerto de Santa María (Cádis)

21 de Junho de 2001, 21.30 horas, Nelas (Praça do Município)

Mitos Clássicos na Poesia Portuguesa Contemporânea,

grupo de Teatro Clássico de Conimbriga

1 de Julho de 2001, 21.45 horas, Termas Romanas de Braga

Os Heraclidas de Eurípides, grupo Thíasos do IEC

5 de Julho de 2001, 21.30 horas, Museu Nacional Machado de Castro

Gorgulho de Plauto, grupo Balbo do IES de Puerto de Santa María (Cádis)

6 de Julho de 2001, 21.30 horas, Museu Nacional Machado de Castro

Coéforas de Ésquilo, grupo Balbo do IES de Puerto de Santa María (Cádis)

7 de Julho de 2001, 21.30 horas, Teatro Viriato (Viseu)

Coéforas de Ésquilo, grupo Balbo do IES de Puerto de Santa María (Cádis)

8 de Julho de 2001, 21.45 horas, Termas Romanas de Braga

Comédia da Marmita de Plauto, grupo Balbo do IES de Puerto de Santa María (Cádis)

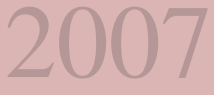

14 de Julho de 2001, 21.30 horas, Castelo Rodrigo

Os Heraclidas de Eurípides, grupo Thíasos do IEC

15 de Julho de 2001, 16.30 horas, Centro Cultural da Mêda

Os Heraclidas de Eurípides, grupo Thíasos do IEC

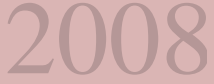




\section{Os Heraclidas de Eurípides}

Grupo Thíasos do IEC

Tradução

Cláudia Cravo

Adaptação e encenação

Delfim Ferreira Leão

Direcção de actores

Delfim Leão, Victor Torres, Rui Henriques

Guarda-roupa

Luísa Ferreira, Maria Valente, Delfim Leão

Caracterização e adereços

Ana Balula, Raquel Gafanha

Confecção de máscaras

Eduardo Mendes, Catarina Ferreira

Luz

Ricardo Monteiro

Som

Isidro Alves

Apoio técnico

Carlos Santos

Elenco

Victor Torres (Iolau)

Delfim Leão (Arauto de Demofonte)

José Luís Brandão (Demofonte)

Alessandra Oliveira (Macária)

Marco Terras (Servo de Hilo)

Ana Rita Miranda (Alcmena)

Paulo Sérgio Ferreira (Mensageiro)

João Paulo Correia (Euristeu)

Rui Henriques (Corifeu)

\section{Coro}

Carla Braz, Cláudia Cravo, Filipe Cravo, Jordana Costa, Liliana Pena, Manuel Santos, Ramiro Costa, Sandra Costa, Sílvia Costa, Susana Bastos, Ricardo Monteiro, Isidro Alves
Quando Eurípides escreve e leva à cena Os Heraclidas (430 a.C.) já fez cinquenta anos e celebra as suas bodas de prata como dramaturgo. A cidade de Atenas está em guerra com Esparta desde o ano anterior, numa guerra que durará ainda vinte e cinco anos até que a derrota definitiva desta cidade se consuma (403 a.C.). É Péricles quem dirige os assuntos da cidade no momento da estreia d'Os Heraclidas.

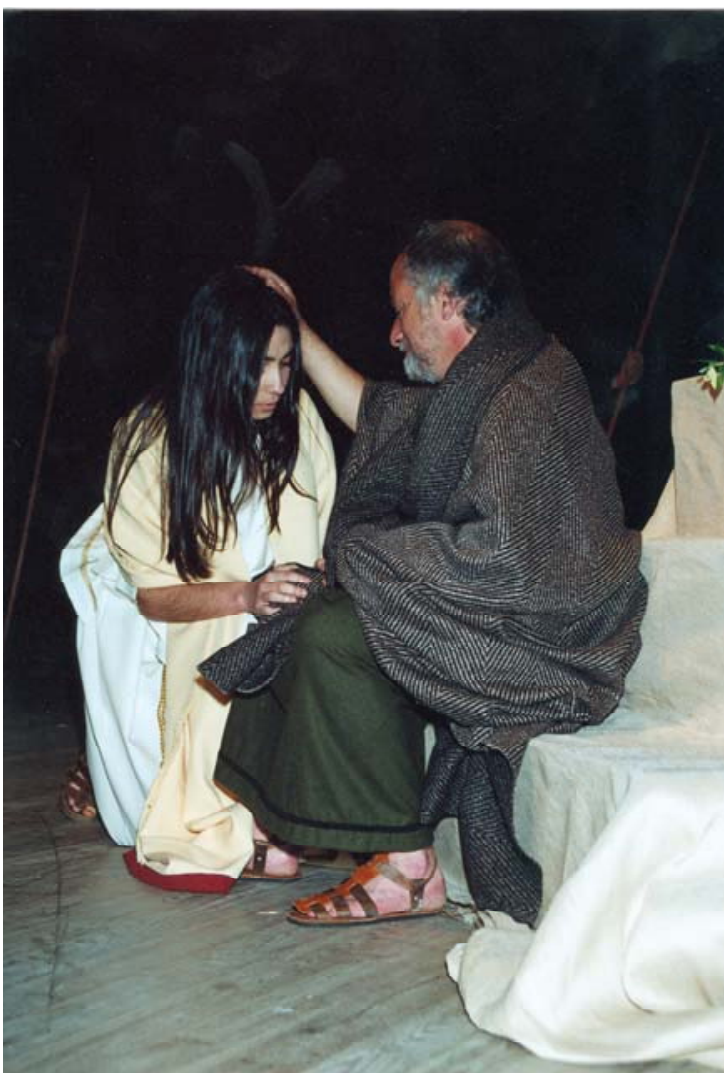

Esta resenha histórica ajudará talvez a compreender melhor por que terá Eurípides escolhido o mito tratado nesta tragédia. Aqui, Atenas, precisamente por causa da hospitalidade prestada aos filhos de Héracles, depara-se com um conflito bélico contra Argos e o seu rei Euristeu, carrasco de Héracles em vida - foi ele que lhe impôs os lendários trabalhos - e implacável perseguidor dos seus filhos depois da morte do herói. Eurípides parte deste argumento para tecer a trama da tragédia de lolau 


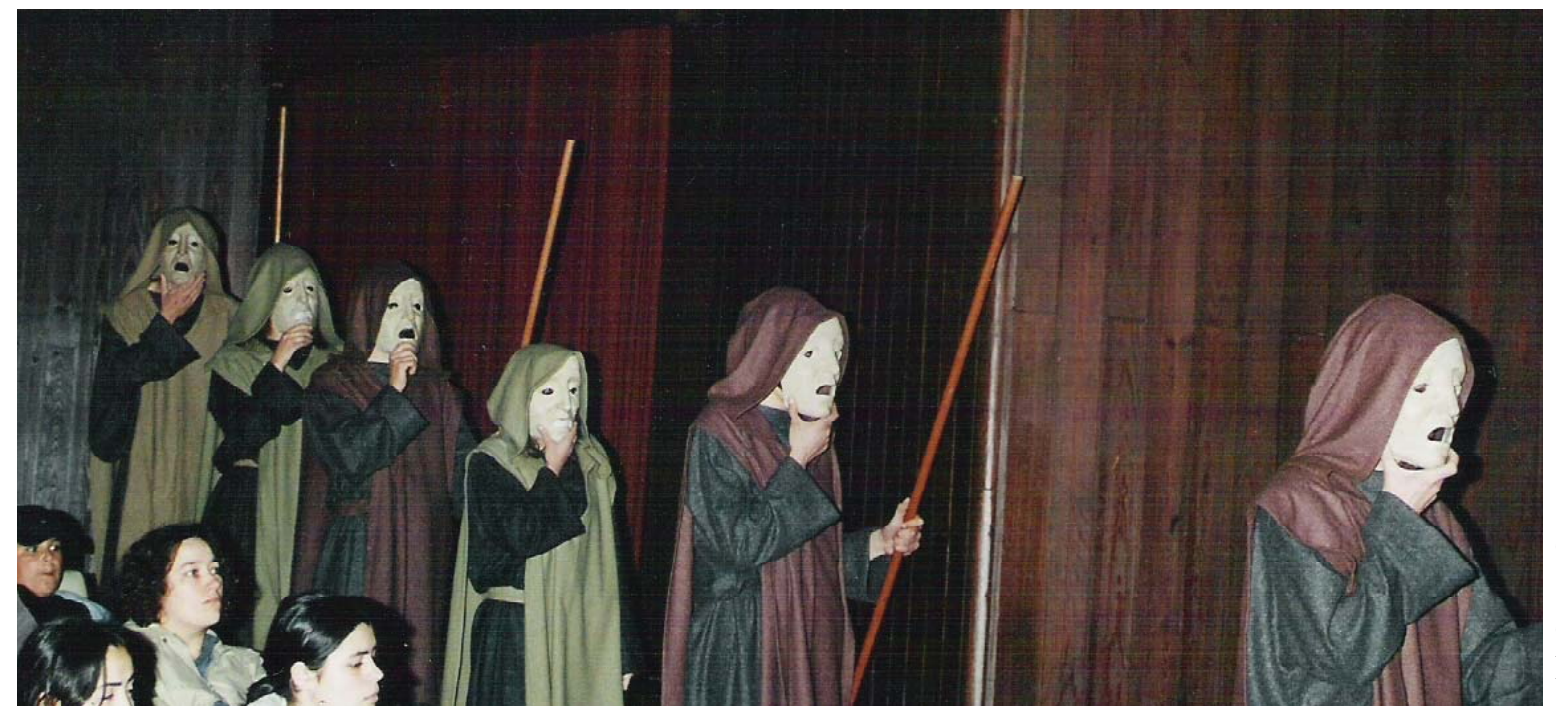

Os Heraclidas

de Eurípides

Salão dos Bombeiros

de Condeixa

Fotos de José Batista

e Alcmena como protectores dos desamparados filhos e filhas de Héracles. O bom e equilibrado rei de Atenas, Demofonte, filho de Teseu, não põe de parte o recurso à guerra para de fazer cumprir os deveres sagrados de quem suplica protecção em frente ao altar de Zeus. A vitória no conflito armado, na qual participará também o rejuvenescido lolau, é assegurada pela jovem filha de Héracles, a mais velha de todas, que se sacrifica voluntariamente, para cumprir a prescrição de um oráculo. Euristeu, derrotado, acaba por aparecer no final da tragédia, para submeter-se à execução imposta por Alcmena, a grande protagonista da segunda parte da tragédia.

do Programa

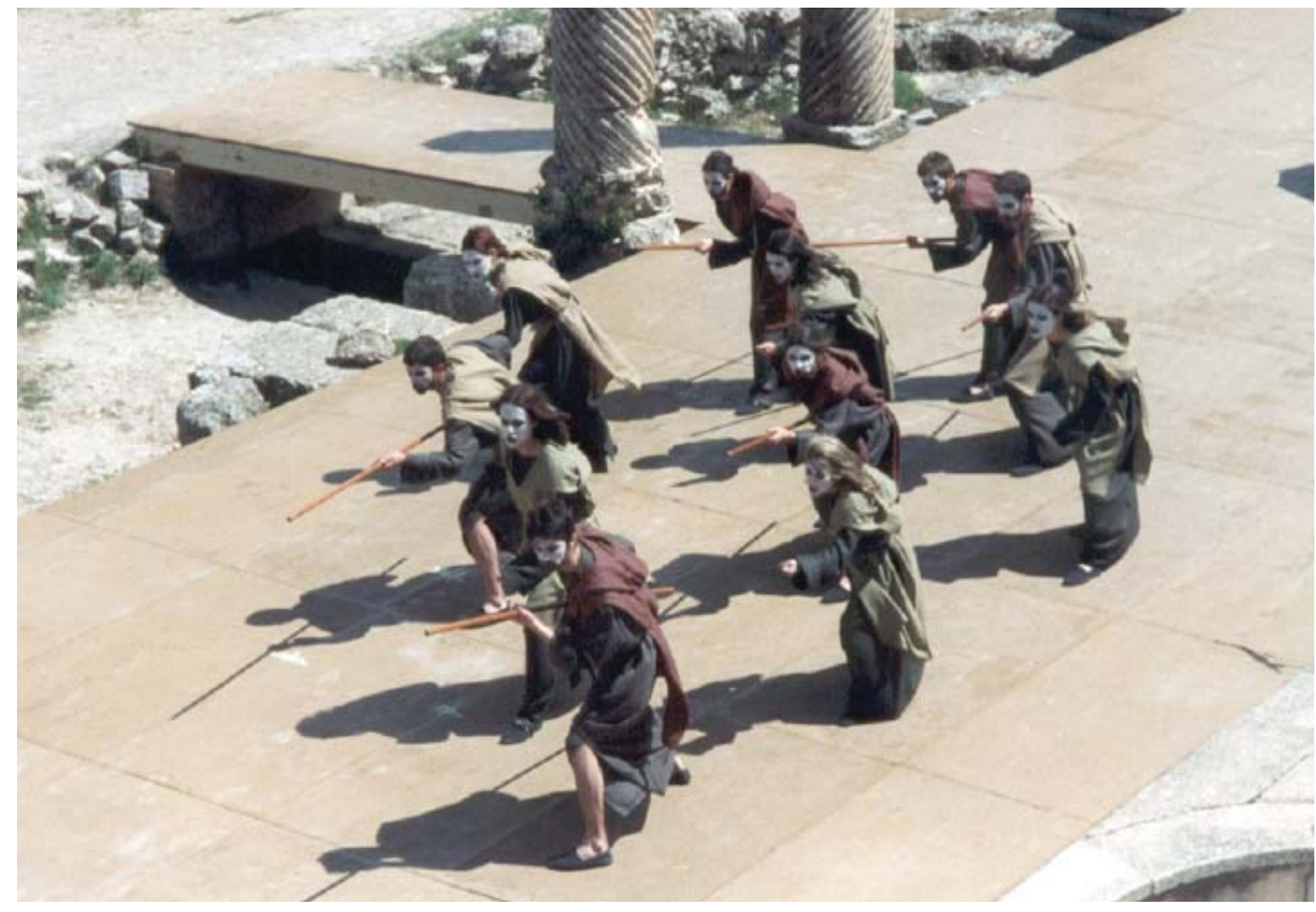

Os Heraclidas de Eurípides Teatro Romano de Segóbriga (2001) Fotos do grupo 
CONDEIXA FESTIVAL DE TEATRO DE TEMA CLÁSSICO COMEÇA HOJE Heraclidas "visita" Conimbriga

Helga Sardinha

"Os Heraclidas"

de Eurípides abre

o II Festival Escolar

de Teatro de Tema Clássico.

A Liga de Amigos

de Conimbriga e o Instituto

de Estudos Clássicos

da Universidade de Coimbra organizam esta iniciativa

dirigida ao público escolar

e à participação

dos docentes e alunos.

"Os Heraclidas" conta a história angustiosa dos filhos de Héracles, que juntamente com a mãe do herói Alcmena e o seu antigo companheiro de aventuras Iolau, se vêem espoliados dos seus direitos pela prepotência de Euristeu, rei de Micenas. Obrigados a mendigar asilo de terra em terra, chegam finalmente a Atenas, onde conseguem ajuda e protecção do soberano da cidade, Demofonte. No entanto, terão ainda que enfrentar a fúria dos seus per-
Diário As Beiras

(23 de Abril de 2001)

Texto de Helga Sardinha seguidores e confrontar-se com a necessidade do sacrifício de uma das filhas de Heracles.

É esta a história levada ao palco hoje, pelas $11 \mathrm{H} 00$, em Conimbriga para assinalar a abertura do Festival. Uma produção do grupo de teatro Thíasos, encenada por Delfim Leão, que tem a preocupação de respeitar aspectos materiais do teatro grego - como o vestuário, máscaras e arranjo musical de forma a que 0 espectador do início do terceiro milénio possa viajar até à Atenas do século $\mathrm{V}$ a.C.

Na parte da tarde são duas as realizações teatrais agendadas: "Mitos Clássicos na poesia Portuguesa Contemporânea", pelas 15H30, em Conimbriga, pelo Grupo de Teatro Clássico de Conimbriga, e "Orfeo e Eurídice", de Gluck, também às $15 \mathrm{H} 30$, na Igreja de S. João de Almedina, no Museu Machado de Castro, pelo Conservatório de Música de Coimbra.

0 II Festival Escolar de Teatro de Tema Clássico pro-

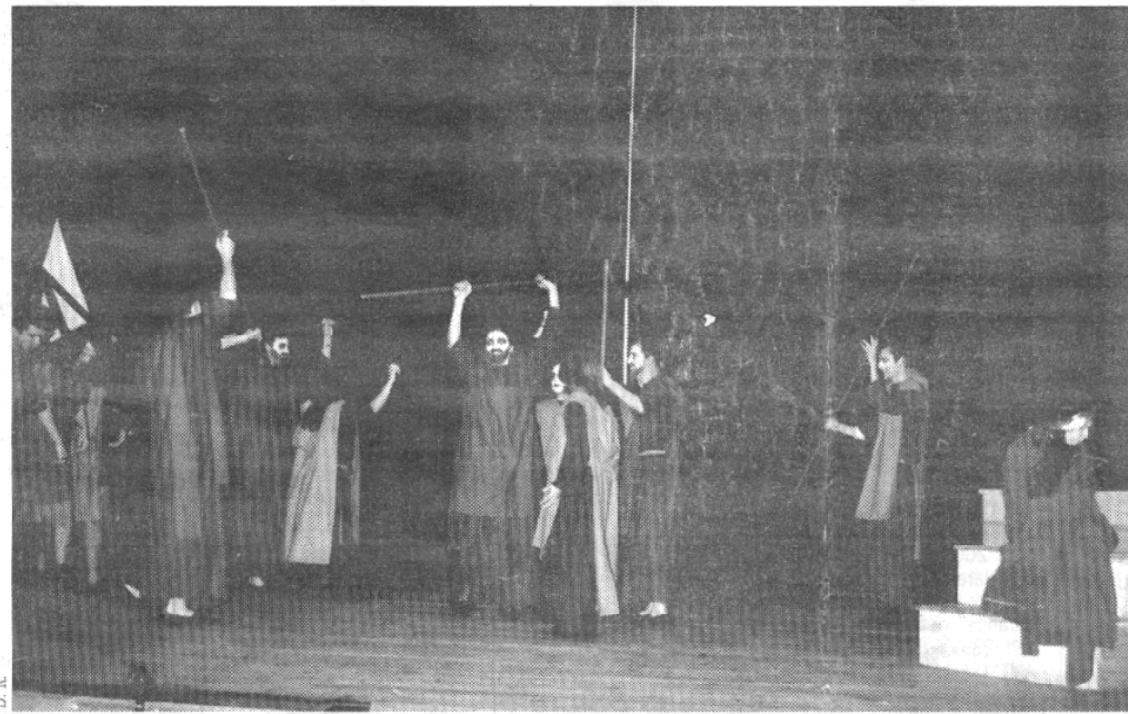

0 II Festival Escolar de Teatro de Tema Clássico vai contar com a participação de docentes e alunos

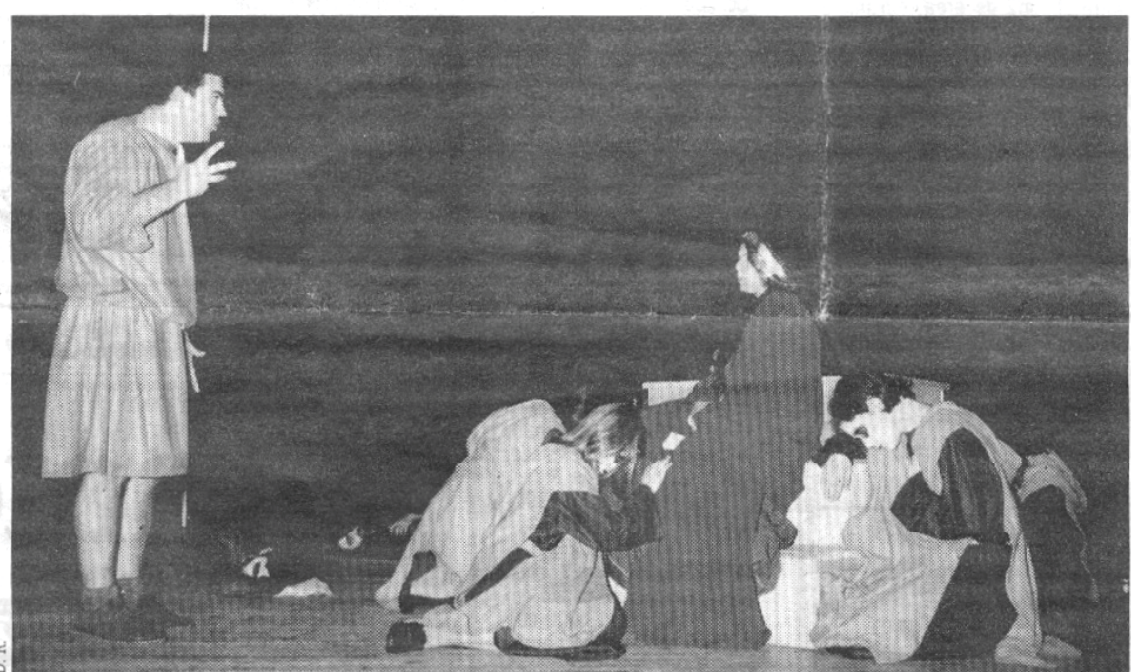

0 evento vai passar por Conimbriga, Coimbra, Tomar e Viseu

longa-se até dia 18 de Maio e é um evento promovido pela Liga de Amigos de Conimbriga e 0 Instituto de Estudos Clássicos da Universidade de Coimbra.

Os participantes, alunos e professores que efectuaram a inscrição, receberam antecipadamente o Bilhete-Livro da peça que vão assistir, tendo sido trabalhado nas aulas.

A organização do Festival pretende, com este projecto, divulgar 0 teatro, em especial 0 teatro clássico, animar espaços monumentais, "criar um evento cultural consistente de âmbito nacional e capaz de fidelizar um público próprio, e estimular a constituição e/ou consolidação de novos grupos de teatro". As expectativas quanto à adesấo do público são as melhores. Espera-se que o número de participantes chegue aos três mil, oriundos de todo 0 país, de Valença a Vila Real de Santo António, da Guarda à Fi- gueira da Foz.

Agora na sua segunda edição, o Festival Escolar de Teatro do Tema Clássico" realizase anualmente entre Abril e Maio, em museus de quatro locais: Conimbriga, Coimbra (Aeminium), Tomar (Sellium) e Viseu. Segue-se o "III Festival Internacional de Teatro de Tema Clássico" que decorre anualmente, nos meses de Junho e Setembro, animando espaços monumentais. 


\section{Orfeu e Eurídice}

Acção dramática em três actos

Classe Canto e Drama

Conservatório de Música de Coimbra

\author{
Música \\ Ch. W. Gluck \\ Libreto \\ Ranieri De’ Calzabigi \\ Tradução \\ Lino Mioli \\ Encenação e direcção artística \\ Isabel Melo e Silva \\ Direcção do Coro \\ Isilda Margarida \\ Piano \\ Júlio Dias

\section{Elenco}

Eduardo Alves, José Paulo Almeida,

Luís Filipe Toscano (Orfeu)

Ana Catarina Reis, Catarina Braga (Eurídice)

Catarina Depraetere Sereno,

Raquel Luís (Amor)

\section{Sopranos}

Ana Carina Reis, Ana Filipa Lopes, Ana Sofia Gonçalves, Carla Alexandra Pires,

Eva Paula Pimenta, Isabel Maria Furtado,

Mónica Baptista,

Maria Dulce Freitas

\section{Contraltos}

Catarina Depraetere Sereno, Carlos Manuel

Pocinho, Catarina Braga, Raquel Luís,

Oriana Cardoso

\section{Tenores}

Eduardo Alves, José Paulo Almeida, Luís Filipe Toscano, Marta Isabel Osório, Rui André Previdência

\section{Baixos}

Carlos Filipe Cruz, David Oliveira, Francisco

Miguel Silvestre, Henrique Sérgio Guerra, Jorge Marinheiro, Mário Miguel Morais,

Nuno Miguel Araújo, Paulo Pereira, Pedro Figueiredo

Numa clareira de um bosque solitário, calmo e ameno, encontra-se o túmulo de Eurídice. Orfeu chora a morte da sua amada; pastores e ninfas acompanham a sua dor.

Surge Amor que transmite uma mensagem de esperança. Orfeu terá que resgatar a sua amada. Orfeu enfrenta as fúrias e os espectros acalmando-os com o doce som da sua lira. $\mathrm{Na}$ cena seguinte, Eurídice, acompanhada dos heróis e heroínas, contempla o espaço celeste. Orfeu encontra esse espaço e Eurídice segue-o com o olhar.

Orfeu conduz Eurídice pela mão sem a olhar. Zangada por não entender a atitude do amado, afasta-se. Num acto de volúpia, Eurídice força Orfeu a olhá-la. Quando tal acontece, ela cai morta. Orfeu chora e recusa viver. Surge então o Amor que evita a morte de Orfeu e, reconhecendo a sua infindável dedicação, desperta Eurídice para a vida.

Amor, Orfeu e Eurídice, seguidos dos heróis e heroínas, festejam a vida.

do Programa

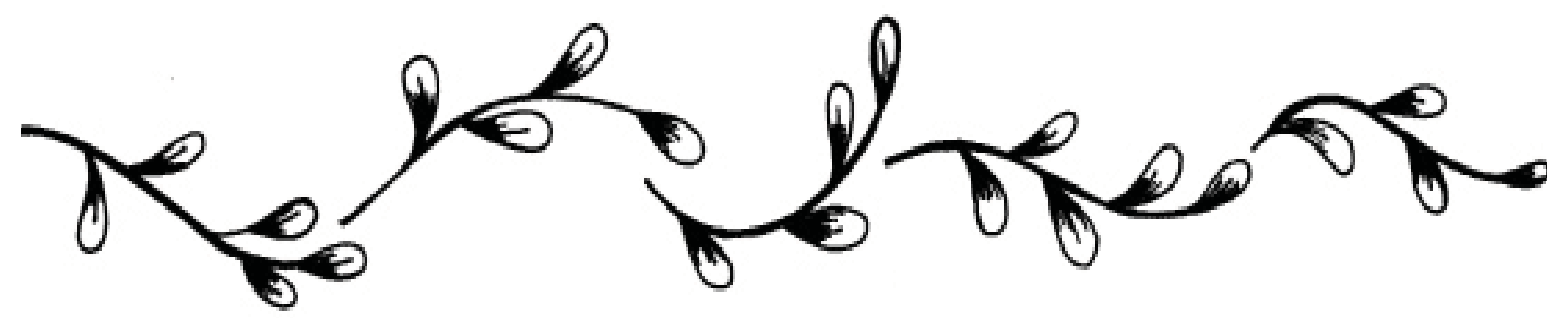




\section{Comédia da Marmita de Plauto}

Grupo Balbo do IES Santo Domingo

Puerto de Santa María (Cádis)

\author{
Encenação \\ Emilio Flor Jiménez \\ Luzes \\ Joaco Arjona \\ Som \\ Antonio Pecho \\ Elenco
}

Marcos Collado Martín (Megadoro)

Nerea Miranda Ramírez (Eunómia)

Fátima Jiménez Enrique (Licónides e Ántrax)

Eva Rodríguez Cruz (Congrião)

Jesús María Gutiérrez Torres (Estrobilo)

Javier Ortega (Euclião)

Patricia López (Estáfila)

Luisa Pinto Tey (Velha rica)

María Isabel Crespo García (Fedra)

Jorge Romo Serrano, Juan Lorca (Lares)

Bailarinas

Esther Pumar Reyes, Lisi Mena Linder, Marga

Domínguez Sánchez,

Maria Isabel Crespo García

Mimos

Jorge Romo Serrano, Jesús María Gutiérrez

Torres, Adrian Varo García

Flautistas

Jorge Romo Serrano, Adrian Varo García

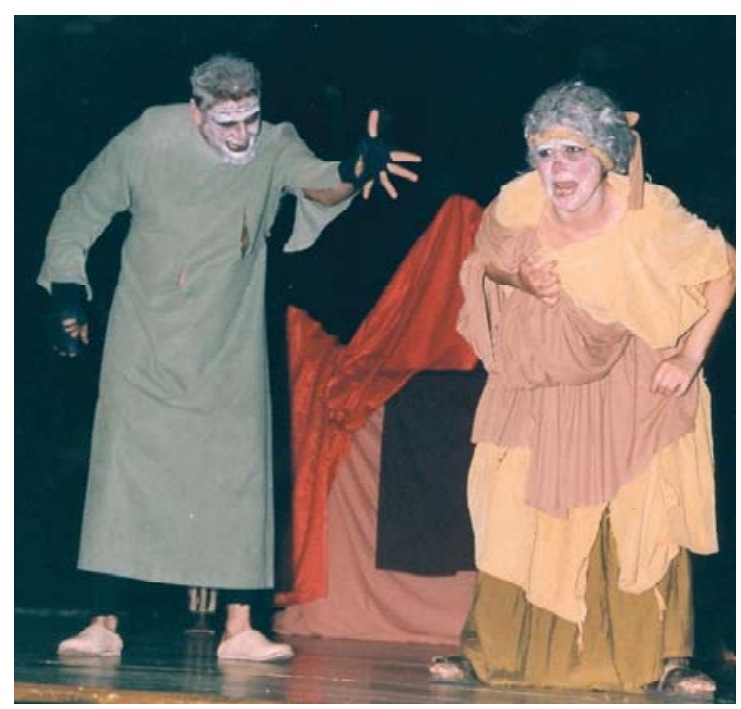

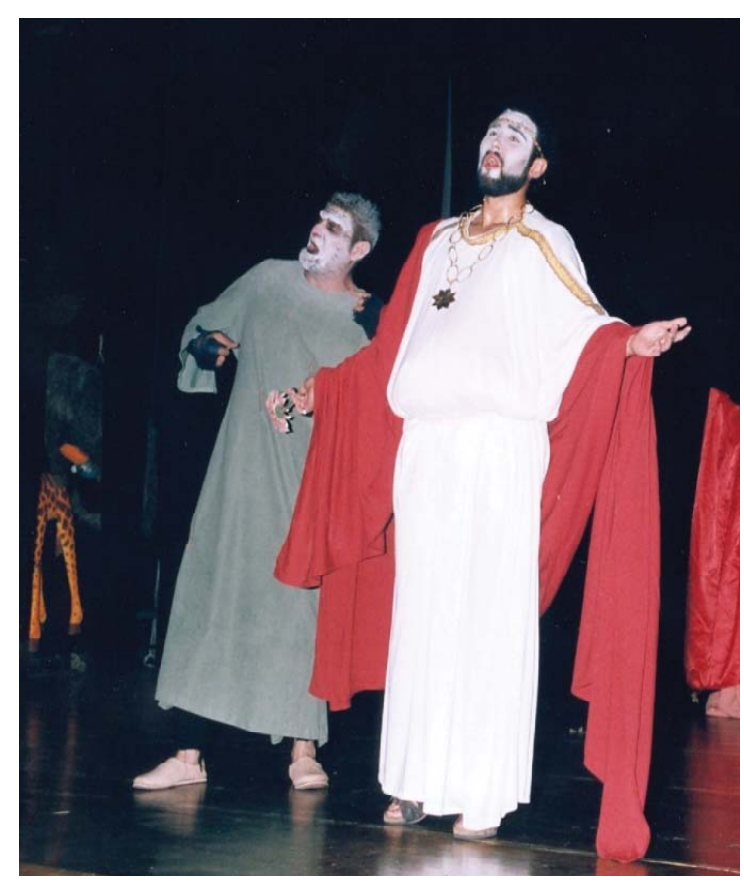

O velho Euclião vive angustiado pelo medo de perder uma marmita cheia de ouro encontrada em sua casa. O rico Megadoro, seu vizinho, animado pela sua irmã Eunómia, pede a Euclião a mão da sua filha. Tudo se complica, pois ninguém sabe, a não ser a velha Estáfila, que a filha havia sido violada pelo jovem Licónides, sobrinho de Megadoro. Toda a acção se anima com a aparição de cozinheiros contratados para o casamento. O desespero do velho não terá limite quando Estrobilo lhe rouba a panela. De nada interessa, pois o desenlace será feliz.

Com a Comédia da Marmita tentou o grupo conhecer a técnica teatral da comédia romana, especialmente a plautina: tipificação das personagens, equívocos, movimento exagerado, palavrões, burla, quebra de ilusão cénica, canto, etc. 


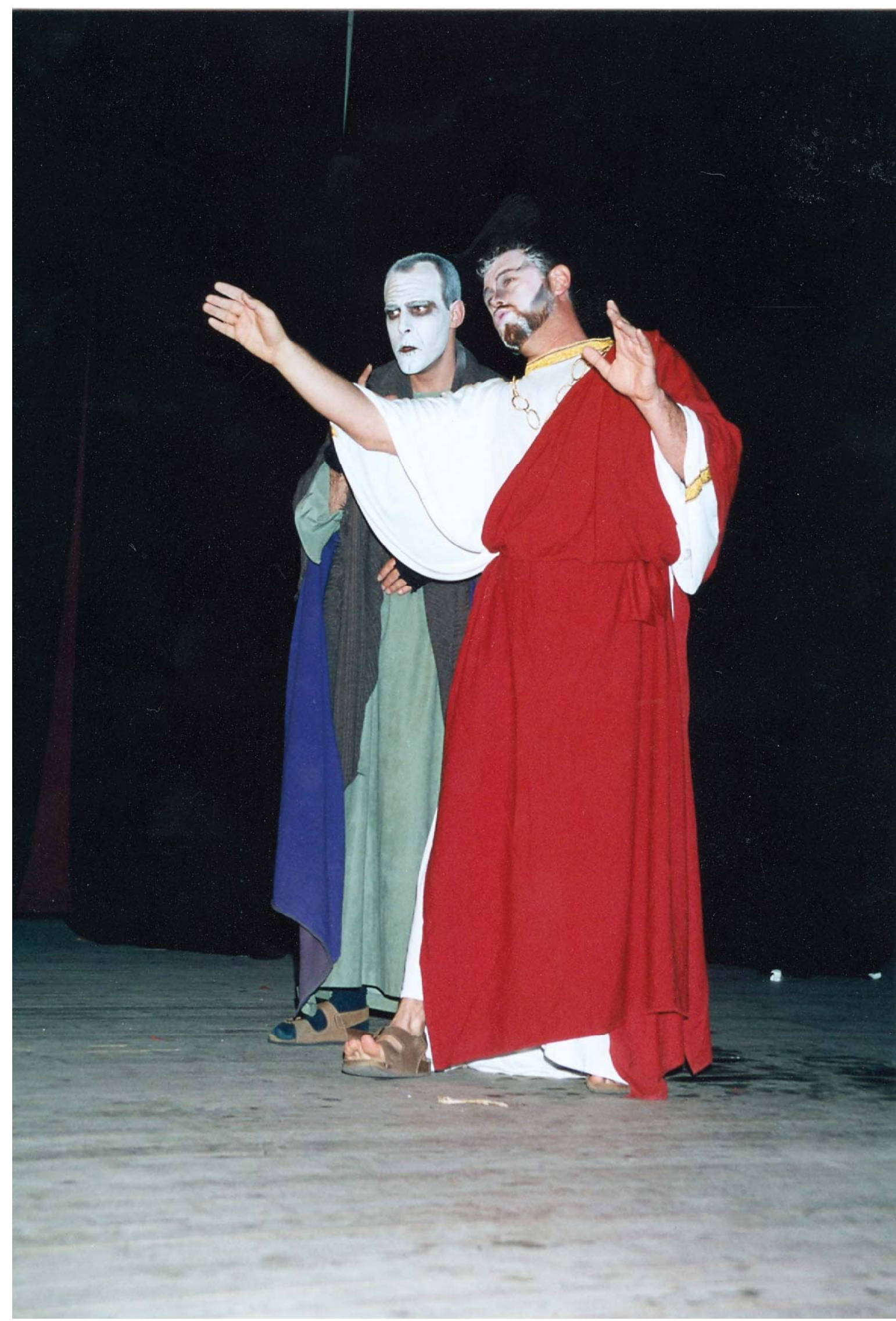

Comédia da Marmita de Plauto

Salão dos Bombeiros de Condeixa

Fotos de José Batista 


\section{Coéforas de Ésquilo}

Grupo Balbo do IES Santo Domingo

Puerto de Santa María (Cádis)

\author{
Encenação \\ Emilio Flor Jiménez \\ Luzes \\ Joaco Arjona \\ Som \\ Antonio Pecho \\ Elenco \\ Javier Ortega (Orestes) \\ Lisi Mena Linder (Electra) \\ Eva Rodríguez Cruz (Clitemnestra) \\ Luisa Pinto Tey (Ama) \\ Marcos Collado Martín (Egisto) \\ Juán Lorca (Agamémnon) \\ Nerea Miranda Ramírez (Corifeu) \\ Coro \\ Fátima Jiménez Enrique,
}

Esther Pumar Reyes, Luisa Pinto Tey, Patricia Buller Viqueira, María Isabel Crespo García, Patricia López, Marga Domínguez Sánchez

\section{Soldados}

Jorge Romo Serrano, Jesús María Gutiérrez Torres,

Adrian Varo García
Agamémnon tinha sido assassinado pela mulher, Clitemnestra, e pelo seu amante, Egisto, no dia em que voltava vitorioso de Tróia. Decorridos dez anos, Orestes regressa do exílio para vingar a morte do pai. Nessa tarefa, ajudá-lo-á a irmã, Electra, com o apoio da ama e das escravas.

Considera o grupo que, ao colocar em cena uma tragédia, se iniciou num trabalho especialmente disciplinado, na proposta teatral. Depois de uma fase de estudo filosófico, histórico e literário, aprendeu a penetrar no interior das personagens, realizando um estudo psicológico de cada uma delas. Como são actores jovens, a colocação em cena obrigou-os a um maior controlo corporal, a especial esforço na dicção, a pequenos estudos de dança e música e a uma maior disciplina de gestos.

do Programa

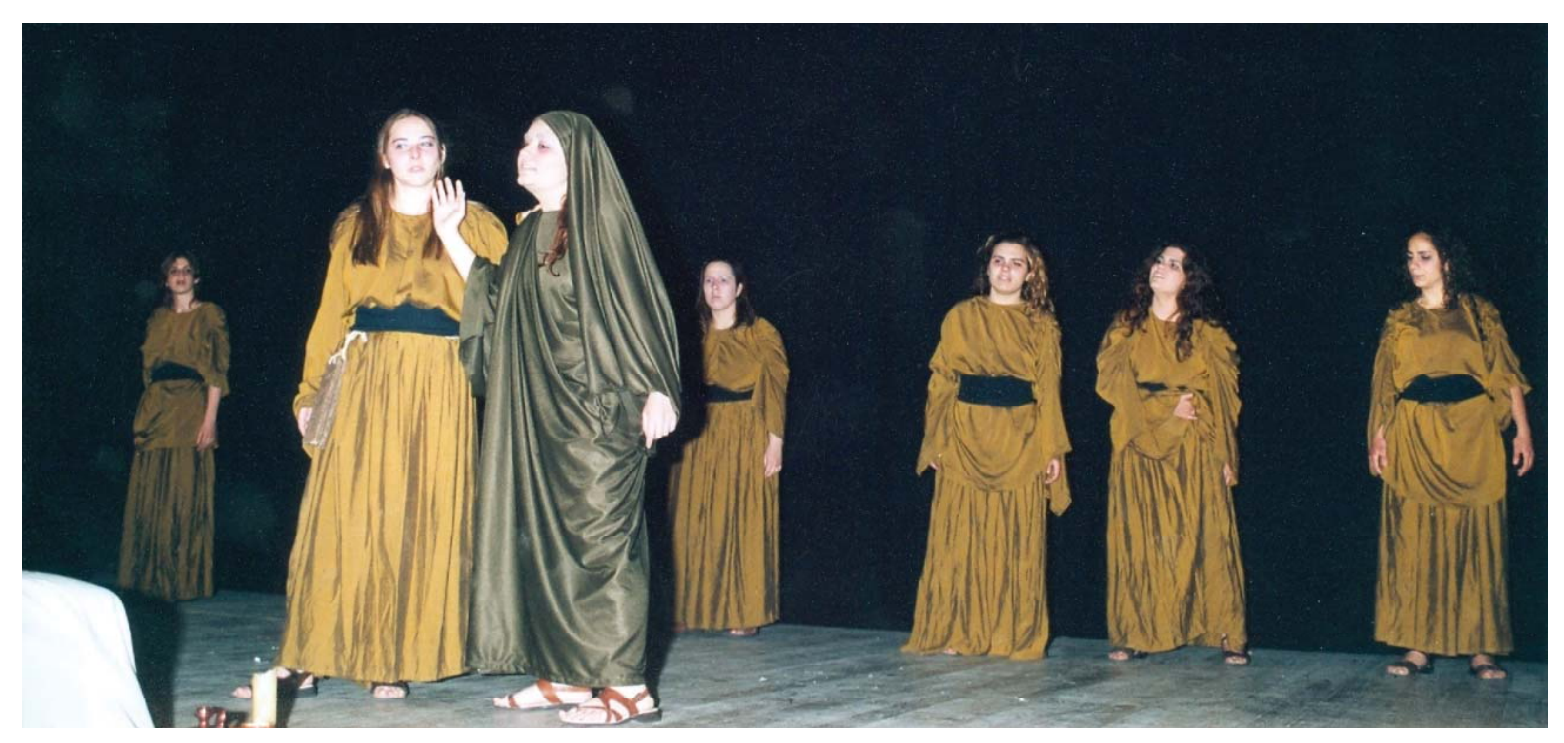




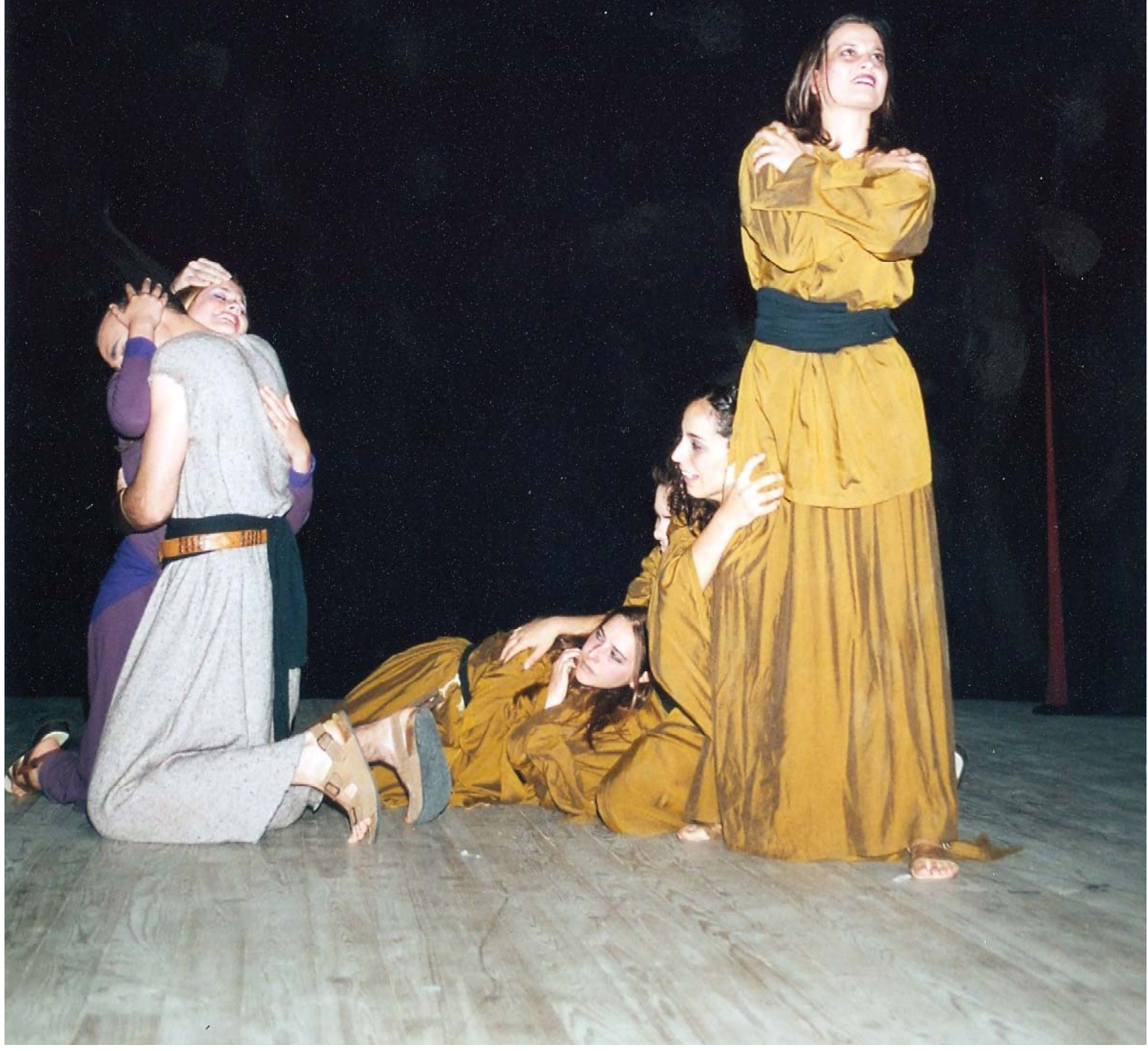

Coéforas de Ésquilo Salão dos Bombeiros de Condeixa

Fotos de José Batista

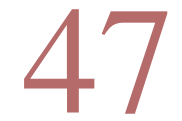




\section{Édipo em Colono de Sófocles}

Grupo Hélios de Madrid

\author{
Encenação e coreografia \\ Gemma López \\ Máscaras \\ Thanos Vovolis \\ Cenografia \\ Tragacanto \\ Adereços \\ Jesús López Salinero \\ Confecção do vestuário \\ La Soleá \\ Luz e som \\ Carlos Guitart \\ Elenco \\ Juan Diego Guerrero (Édipo) \\ Izaskun Puente (Antígona) \\ Luis Martínez (Estrangeiro) \\ Susana Santolaria (Ismena) \\ Mario Paredes (Teseu) \\ Antonio J. Caballero (Creonte) \\ Javier García (Polinices) \\ Javier Torrijos (Mensageiro) \\ Coro
}

Cayetana Paso (Corifeu), María Mellén,

Noelia Mera, Laura López, Eva Andrés,

Gloria Arroi, Mar Monserrate, Javier García, Laura Pascual, Ruth Rubio, Andrea Cristóbal, Laura Chica, Amparo Torres, Oscar García, Javier Torrijos
Quando Édipo descobre que assassinou, sem saber, o seu pai Laio, e que sem saber compartilhou o leito com a sua mãe, Jocasta, cega-se a si próprio e sai de Tebas, capital da Beócia, desterrado, na companhia das filhas.

Tempos depois, encontramo-lo errante, vagabundo em Colono, um pequeno demo de Atenas. A sua filha Antígona guia-o, cego e maltratado, em busca de um lugar em que possa viver os poucos dias que lhe concedam os deuses em paz. O rei de Atenas, o lendário Teseu, ajudá-lo-á a vencer a resistência que lhe oferecem os populares de Colono e dar-lhe-á hospitalidade e protecção.

Mas, ao que parece, ninguém quer deixar viver em paz o ancião. Vem Creonte, também ele carregado com o peso dos anos, para propor-lhe o regresso à sua terra e reconciliação. Vem o seu filho Polinices - que consentira na expulsão do pai de Tebas - pedir-lhe perdão e apoio antes de enfrentar Etéocles, o irmão que se nega a abandonar o trono.

Édipo não quer saber nem do cunhado Creonte nem do filho Polinices. A única coisa que estes conseguem é despertar em Édipo a indignação, o rancor e a cólera.

Édipo apenas deseja, após existência tão iníqua, que o deixem viver em paz nos seus últimos dias. Mas a paz só chegará única e simplesmente com a morte. Será esta que porá fim a tanta luta, tanto sacrifício e tanto desassossego. A morte como libertação e a poesia como bálsamo para o espírito são o consolo que conforta Édipo.

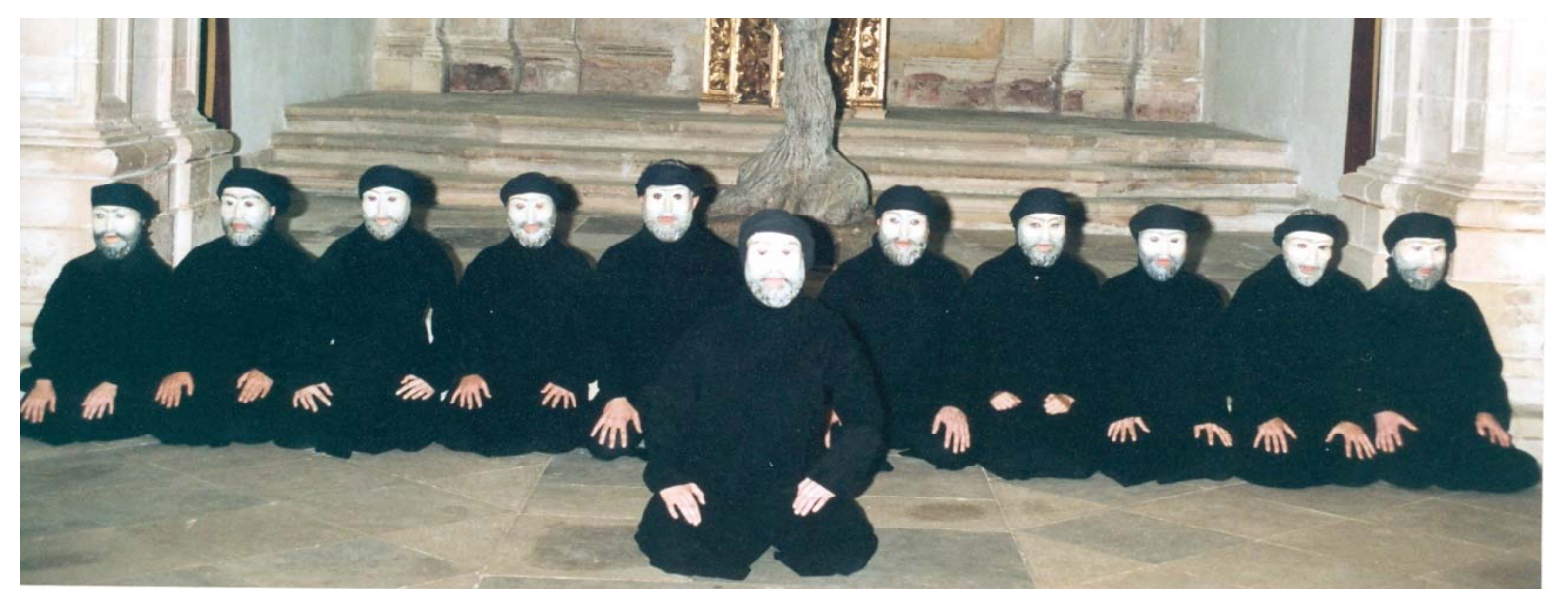



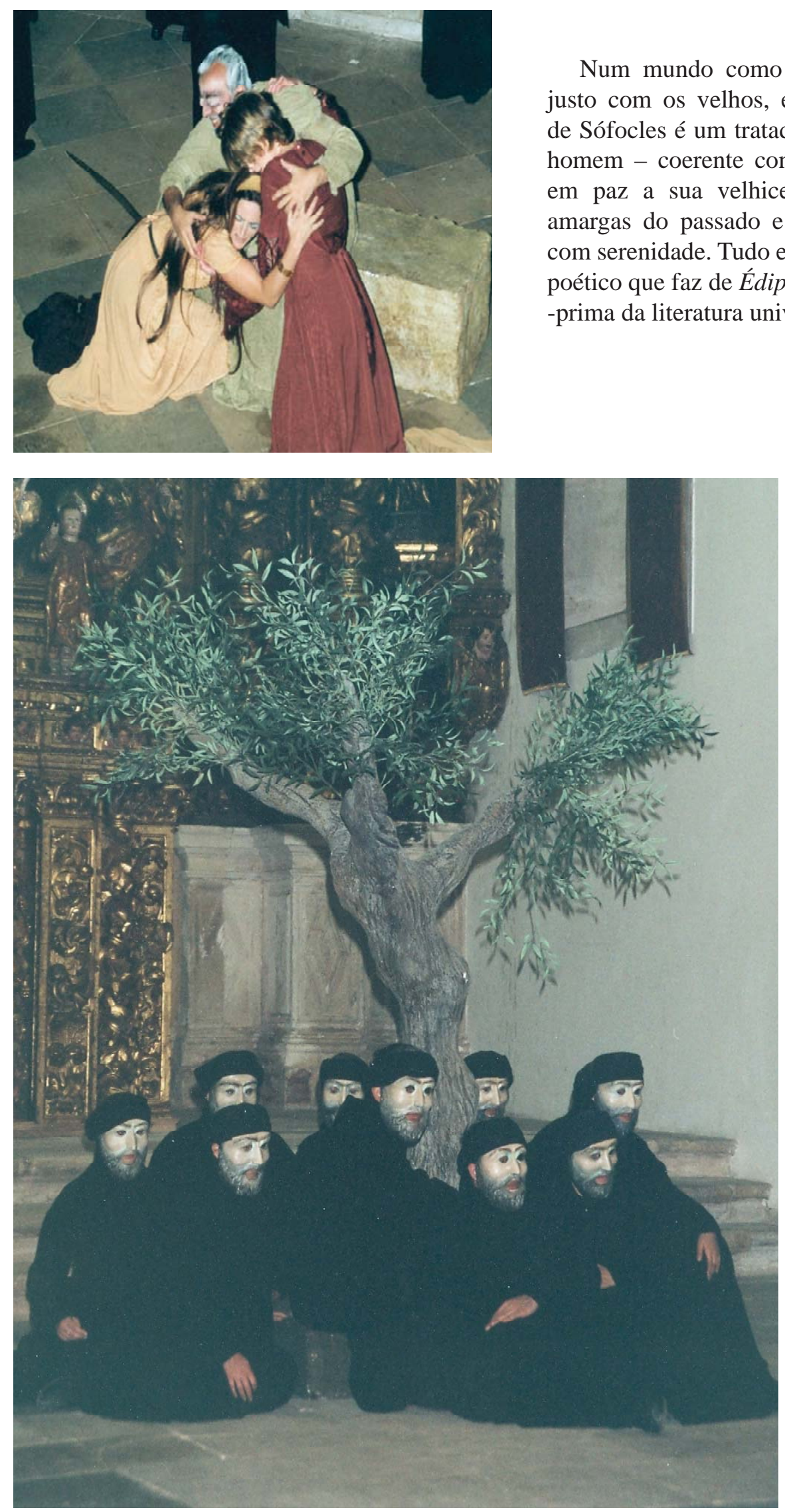

do Programa

Édipo em Colono de Sófocles Museu Nacional

Machado de Castro

Fotos de José Batista 


\section{Íon de Eurípides}

Grupo Selene do IES Carlos III de Madrid

\section{Encenação e coreografia}

Gemma López, José Luis Navarro

\section{Luz e som}

Carlos Guitart, Miguel Ángel Pérez

Cenografia

Tragacanto

Adereços

Jesús López Salinero

Fotografia

Ángel Martínez

Figurinos

Gemma López Martínez

\section{Confecção do vestuário}

La Soleá, María José Blasco

\section{Elenco}

Oliver Plazas (Íon)

Rebeca Amez (Creúsa)

Francisco Blanca (Xuto)

Sara Lamparero (Pítia)

Javier García (Hermes)

Laura Sánchez Castanar, Laura López (Atena)

Carolina Sánchez Blanco (Ama de Creúsa)

Ariana Rodríguez (Escrava de Creúsa)

Pilar Aranda (Mensageiro)

Rocío Fernández, María Álvarez,

Marta Martín (Escravas da Pítia)

\section{Coro}

Virginia Oteros (Corifeu)

Tania Samalea, Sara Cazorla, Leticia Flores,

Eva Andrés, Carla González,

Jessica Torres, Diana Curtido,

Susana Cristóbal, Teresa Torres, Vanessa Meis,

Leticia Velle, Yolanda Almeida
Apolo apaixonou-se por Creúsa, filha de Erecteu, o lendário rei de Atenas. Como consequência esta deu à luz um filho que abandonou ao nascer nas rochas à beira da Acrópole. Mas o deus Hermes, com pena da criança, tomou-a nos braços e levou-a até Apoio, ao santuário de Delfos. Ali, o miúdo será adoptado pela profetisa do deus, a Pítia, que o criará, alimentará e educará como a mãe o faria. Íon, mais tarde assim chamado, crescerá em Delfos e será o administrador do templo de Apolo.

Por sua vez, Creúsa casou com Xuto, aliado dos Atenienses, união que não teve filhos. Decidem, por isso, recorrer a Delfos e consultar o oráculo de Apolo. Terá então lugar uma série de peripécias. Íon e Creúsa conhecem as suas verdadeiras identidades e mãe e filho abraçam-se perante um Xuto atónito e perplexo, a quem a deusa Atena dará uma explicação sincera e uma mensagem de esperança, que se estenderá a todos os que participam na obra.

Apesar da sua aparente forma de melodrama, Íon envolve uma enorme dose de tensão, suspense e intriga. A acção toma direcções inesperadas, muda de forma imprevista e chega a surpreender os próprios protagonistas da acção dramática.

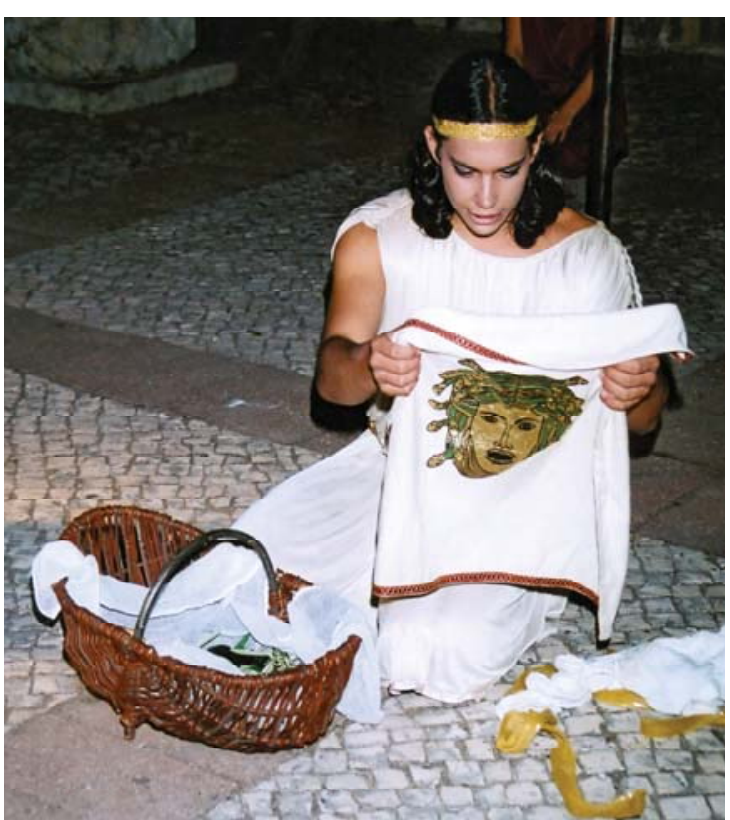






Ainda que considerada uma tragédia menor, não podemos esquecer nem negar que estamos perante uma peça completa. Divindades, escravas, jovens, mulheres enganadoras, mensageiros, personagens exóticas e misteriosas compõem um mosaico variado e coeso de uma grande beleza estética. O coro, formado por mulheres de Atenas, companheiras de Creúsa, toma partido na acção e contribui para realçar a beleza do incomparável local em que transcorre a acção: o santuário de Apolo em Delfos.

do Programa

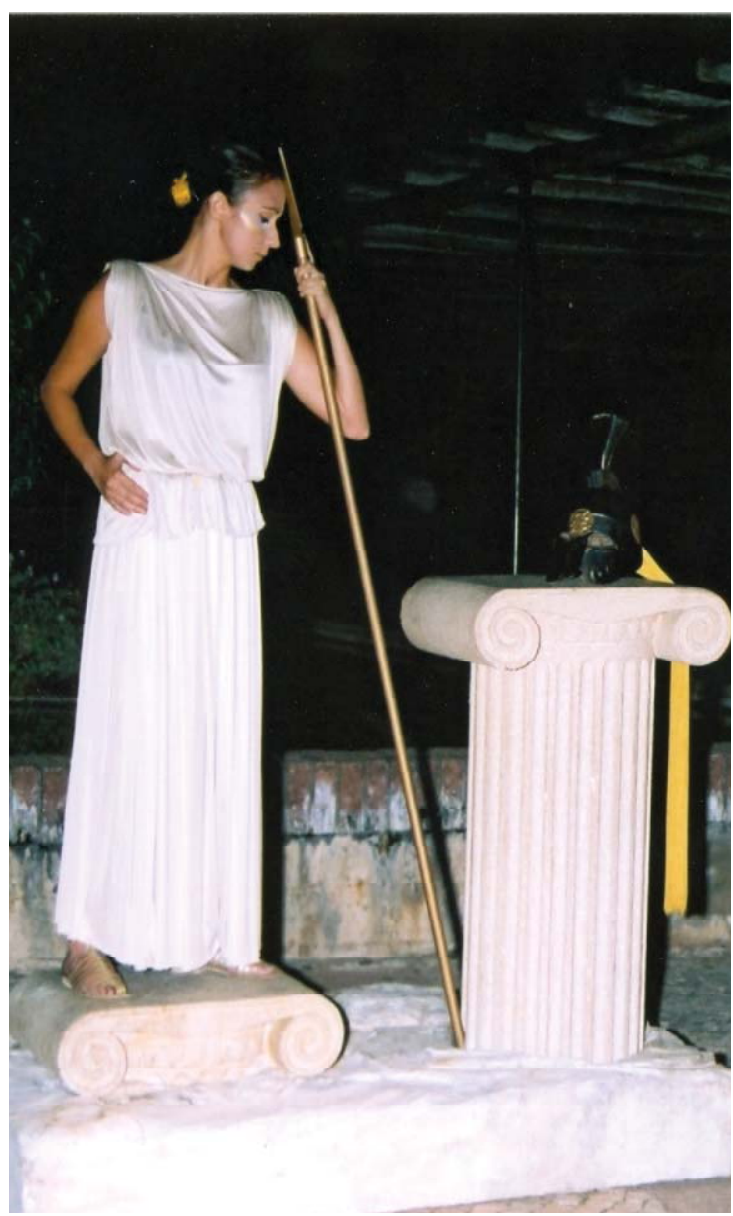

Íon de Eurípides Páteo da Universidade de Coimbra

Fotos de José Batista 


\section{O Poeta e o Maçador}

A partir da sátira IX de Horácio

Grupo Thíasos do IEC

\section{Selecção e tradução}

Walter S. Medeiros

Adaptação e encenação

Rui Henriques

\section{Elenco}

Rui Henriques, Rui Monteiro
Esta dramaturgia de Horácio, adaptada para dois actores por Rui Henriques, centra-se na figura do poeta (Rui Monteiro) e num importuno maçador (Rui Henriques), que se desdobra em várias outras personalidades da Roma antiga. $\mathrm{O}$ trabalho, pensado para favorecer uma adaptação rápida a pequenos espaços, onde seja possível uma interacção próxima com os espectadores, vive, em particular, da grande capacidade que Rui Henriques tem para se metamorfosear em personalidades distintas, apoiado por uma sugestiva selecção musical.

Delfim Ferreira Leão, in Maria de Fátima Silva (coord.), Representações de Teatro Clássico no

Portugal Contemporâneo III

(Coimbra 2004) 182.

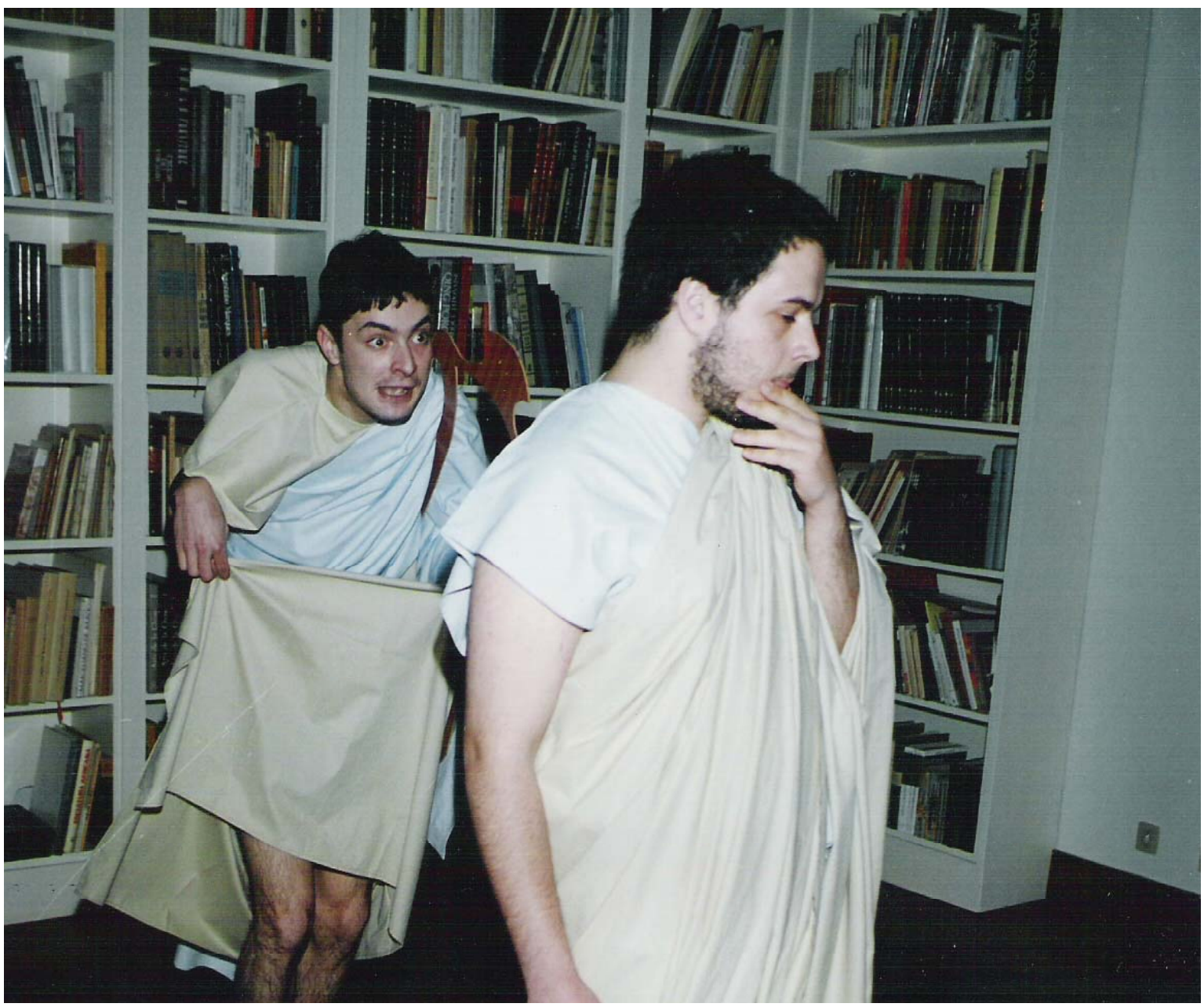




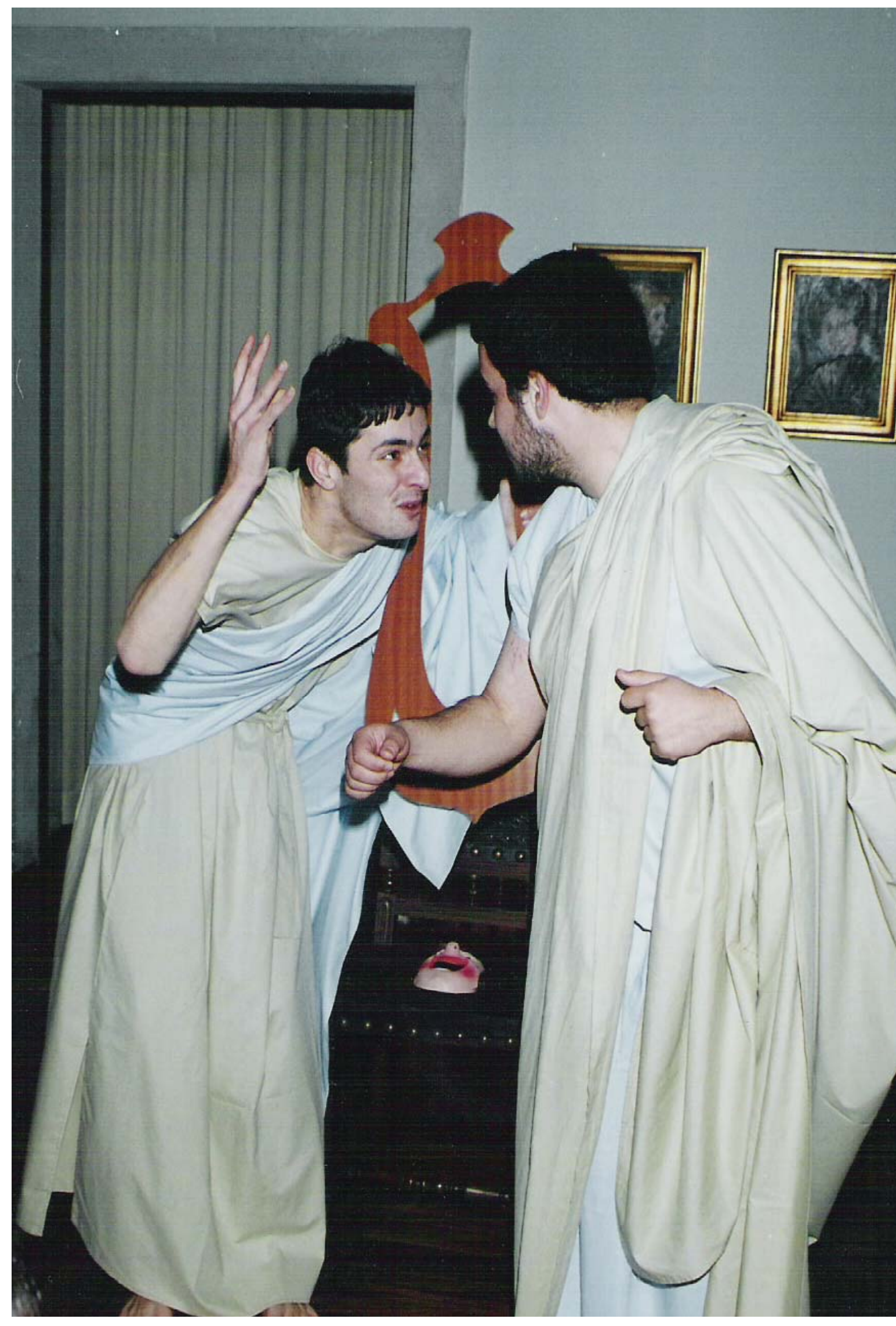

O Poeta e o Maçador Museu Nacional Machado de Castro Fotos de José Batista 


\section{FESTIVAL DE VERÃO \\ DE TEATRO DE TEMA CLÁSSICO}

25 de Junho de 2002, 21.30 horas, Museu Nacional Machado de Castro

Anfitrião de Plauto, grupo Thíasos do IEC

29 de Junho de 2002, 21.30 horas, Conimbriga

Íon de Eurípides, grupo Selene do IES Carlos III de Madrid

3 de Julho de 2002, 21.30 horas, Termas Romanas de Braga

Íon de Eurípides, grupo Selene do IES Carlos III de Madrid

5 de Julho de 2002, 21.30 horas, Praça 8 de Maio (Coimbra)

A Comédia do Fantasma de Plauto, grupo Balbo do IES de Puerto de Santa María (Cádis)

6 de Julho de 2002, 21.30 horas, Termas Romanas de Braga

As Troianas de Eurípides, grupo Balbo do IES de Puerto de Santa María (Cádis).

7 de Julho de 2002, 21.30 horas, Mosteiro de Tibães (Braga)

As Coéforas de Ésquilo, grupo Balbo do IES de Puerto de Santa María (Cádis)

8 de Julho de 2002, 21.30 horas, Museu Nacional Machado de Castro

As Coéforas de Ésquilo, grupo Balbo do IES de Puerto de Santa María (Cádis)

9 de Julho de 2002, 17.30 horas, Citânia de Sanfins

Comédia da Marmita de Plauto, grupo Balbo do IES de Puerto de Santa María (Cádis)

9 de Julho de 2002, 21.30 horas, Auditório Mirita Casimiro (Viseu)

Lisístrata de Aristófanes, grupo Calatalifa de Madrid

10 de Julho de 2002, 21.30 horas, Aparthotel Sottomayor (Figueira da Foz)

Lisístrata de Aristófanes, grupo Calatalifa de Madrid

11 de Julho de 2002, 21.30 horas, Páteo da Universidade de Coimbra

Lisístrata de Aristófanes, grupo Calatalifa de Madrid

13 de Julho de 2002, 21.30 horas, Vila Nova de Foz Côa

Anfitrião de Plauto, grupo Thíasos do IEC

14 de Julho de 2002, 21.30 horas, Centro Cultural de Mêda

Anfitrião de Plauto, grupo Thíasos do IEC

20 de Julho de 2002, 21.30 horas, Castelo de Pinhel

Anfitrião de Plauto, grupo Thíasos do IEC

21 de Julho de 2002, 21.30 horas, Castelo Rodrigo

Anfitrião de Plauto, grupo Thíasos do IEC

22 de Julho de 2002, 21.30 horas, Conimbriga

Antígona de António Pedro, grupo Teat®amus do Colégio de Calvão

27 de Julho de 2002, 17.30 horas, Conimbriga

As Mulheres no Parlamento de Aristófanes, grupo de teatro da Escola Secundária de Trancoso
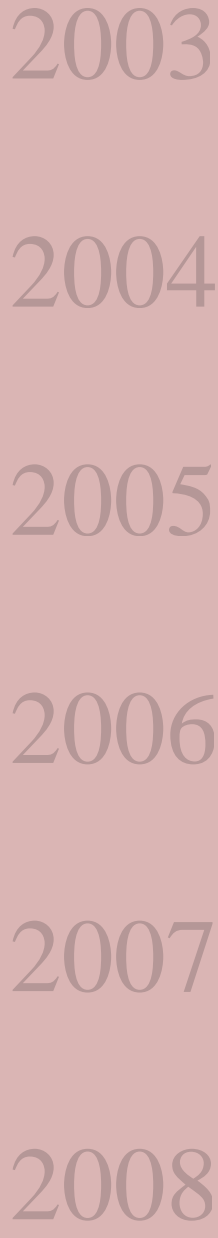

2002 


\section{Anfitrião de Plauto}

Grupo Thíasos do IEC

\section{Tradução}

C. A. Louro da Fonseca

Adaptação e encenação

Victor Torres

Consultor

José Luís Brandão

Luminotecnia

Carlos Santos

Sonoplastia

Isidro Alves, Carlos Jesus

Selecção Musical

Victor Torres

Figurinos

Ana Balula, José Luís Brandão

Execução do guarda-roupa

Inês Santos

Adereços

Ana Balula, Carlos Santos, Victor Torres

\section{Elenco}

Paulo Sérgio Ferreira (Relator inicial)

José Luís Brandão (Anfitrião)

Nuno Gertrudes (Sósia)

Delfim Leão (Júpiter)

Bruno Amaral (Mercúrio)

Sílvia Costa,

Ana Catarina Rodrigues (Alcmena)

Carla Braz, Amélia Álvaro de Campos,

Lia Nunes, Susana Bastos,

Verónica Fachada (Brómias)

Patrícia Martinho, Sónia Simões, Sónia Freitas, Isabel Santos (Figurantes)
Foi a terceira vez que o Thíasos encenou Plauto; já antes Carlos Alberto Louro Fonseca tinha encenado uma parte de $O$ soldado fanfarrão e Paulo Sérgio Ferreira $O$ Epídico. A encenação coube a Victor Torres, que tem vasta experiência como actor, e a expectativa era grande para ver o que poderia trazer de novo alguém do meio teatral a um grupo de teatro universitário, maioritariamente constituído por professores e alunos do Instituto de Estudos Clássicos.

O resultado não defraudou as expectativas, pois Victor Torres encontrou algumas soluções dramáticas brilhantes, embora bem distantes da arqueologia teatral romana: pensamos nas portas em pano que, quando alguém simulava bater, abanavam todas, enquanto outra pessoa, fora do palco, batia numas chapas que faziam grande estrondo. A cena de amor em palco entre Júpiter e Alcmena, em que Brómia coloca um leve pano sobre o casal, é outro achado. As duas pessoas que se escondem atrás de um pano e o fazem tremer também sugerem bastante bem as sombras nocturnas e justificam, de forma bastante cómica, os temores de Sósia. Boa opção foi ainda a distribuição da longa intervenção final de Brómia por três actrizes com trejeitos e vozes completamente diferentes. Já que era de prodígios que esse relato falava....

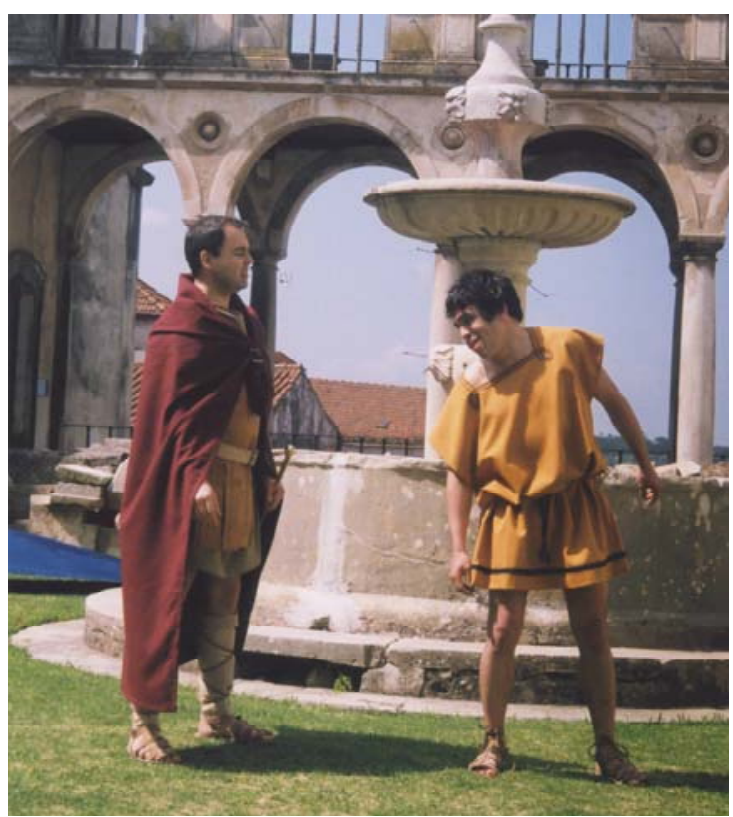


Quanto aos desempenhos, importa destacar o de Delfim Leão, que foi um Júpiter enérgico e coerente. Nuno Gertrudes foi um Sósia que, com tamanha confusão, quase ia ficando louco. Levou muita paulada de Mercúrio e andou com Anfitrião às costas, quando, ao sair do palco, atravessava um rio. Esta cena não tinha, de resto, grande fundamento dramático e, quando Nuno Gertrudes demorava a desapertar as sandálias, verificava-se um tempo morto. Muito sóbria e convincente foi Sílvia Costa no papel de Alcmena: até amuou e fez beicinho.

Em suma, o balanço é bem positivo, sobretudo pela qualidade de muitas das soluções encontradas, que permitiram conseguir efeitos muito bonitos, sem sobrecarregar o palco com cenários pesados.

Paulo Sérgio Ferreira, in Maria de Fátima Silva (coord.), Representações de Teatro Clássico no Portugal Contemporâneo III (Coimbra 2004) 139-140.
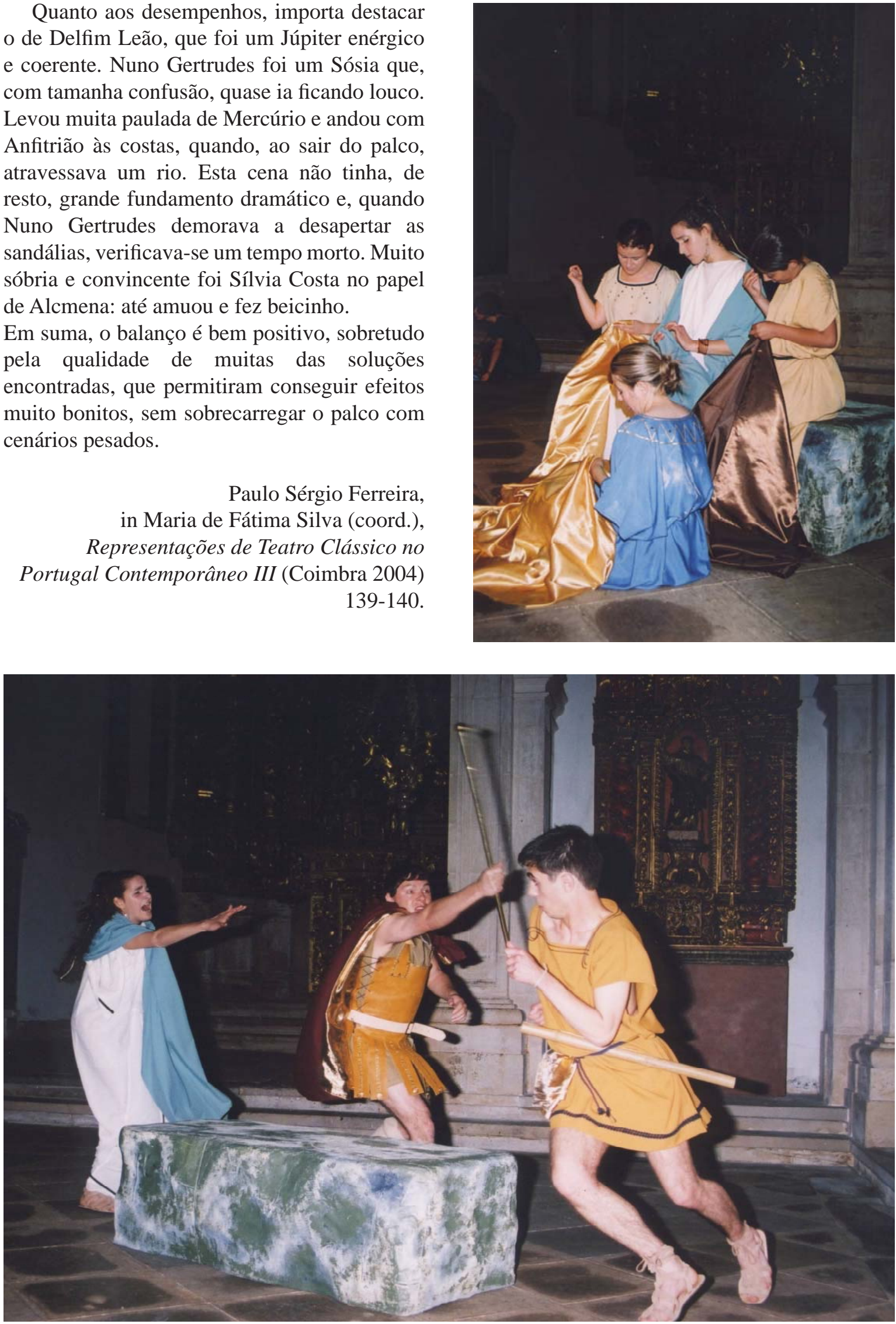

Anfitrião de Plauto Museu Nacional Machado de Castro Fotos de José Batista 


\section{Electra de Sófocles}

Grupo Calatalifa de Madrid

\author{
Encenação \\ Pedro Sáenz de Almeida \\ Susana Verdú Martínez \\ Figurinos e adereços \\ Javier Botella \\ Confecção do vestuário \\ Ruth Patricia Sánchez \\ Escultura cénica \\ José Luis Táboas Nogueira \\ Coreografia \\ Susana Verdú Martínez \\ Iluminação e som \\ Sónia García Lázaro \\ Elenco \\ Susana Verdú (Electra) \\ Javier Oleaza (Pedagogo) \\ Luis Jiménez (Orestes) \\ Carlos Martos (Pílades) \\ Susana Millán (Crisótemis) \\ Alba Alonso (Clitemnestra) \\ Raúl Verdú (Egisto)

\section{Coro}

Lucía Díaz (Corifeu), Débora Mamblona, Alba Rodríguez, Patricia Martínez, Paola Martínez, Juan José Sánchez, José Herradón, Pablo Martínez, Victor de Castro
A Electra de Sófocles tem sido tradicionalmente considerada como a mais perfeita das suas obras quanto à estrutura dramática. Ao longo do texto vão-se contrapondo de forma excelente os matizes dramáticos de obscuridade e luz, assimilados respectivamente aos conceitos de dor, crime e injustiça, de um lado, e vingança, restauração e liberdade, do outro. Mesmo assim, encontramos neste drama outra oposição entre verdade dramática e mentira cénica que aparece como "jogo de espelhos".

Mas, de modo paradoxal, a diáfana e envolvente estrutura dramática desta tragédia serve para nos introduzir num mundo fronteiriço com o do reino dos mortos e das divindades infernais, a cujo cargo está a vingança justiceira que dá repouso aos defuntos: Electra, no meio da sua dor e da sua vida miserável, vive para a recordação do seu pai assassinado e acumula rancor contra a mãe e desejos de vingança contra ela.

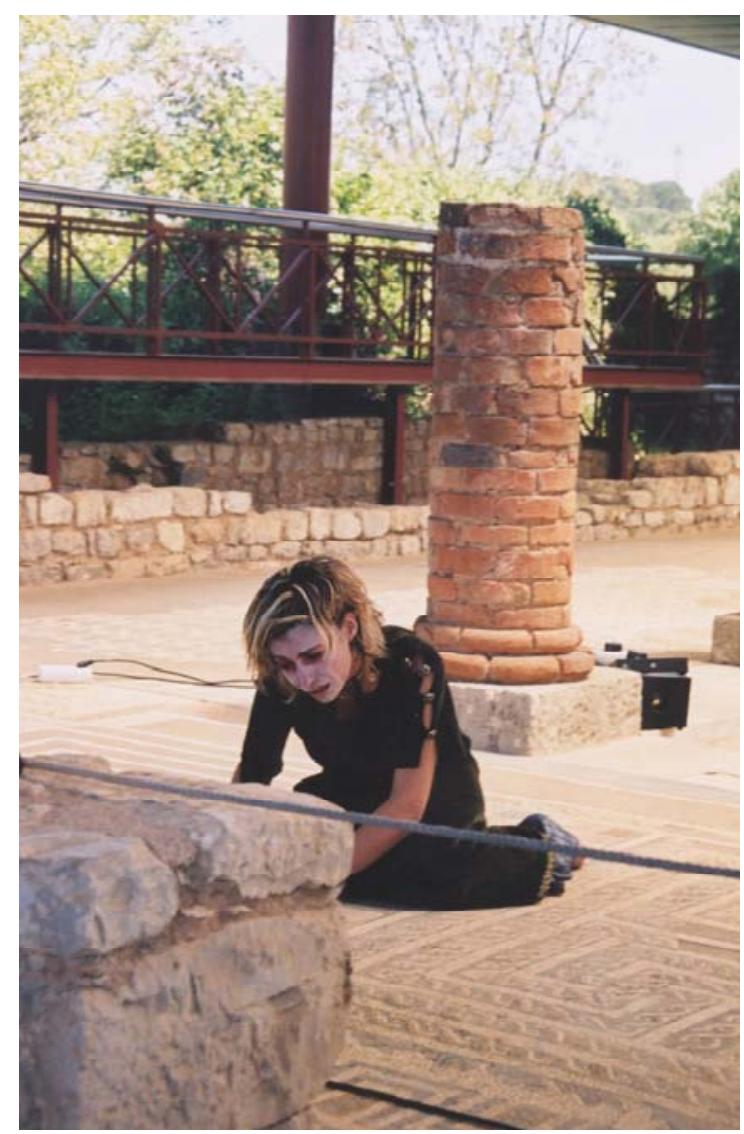




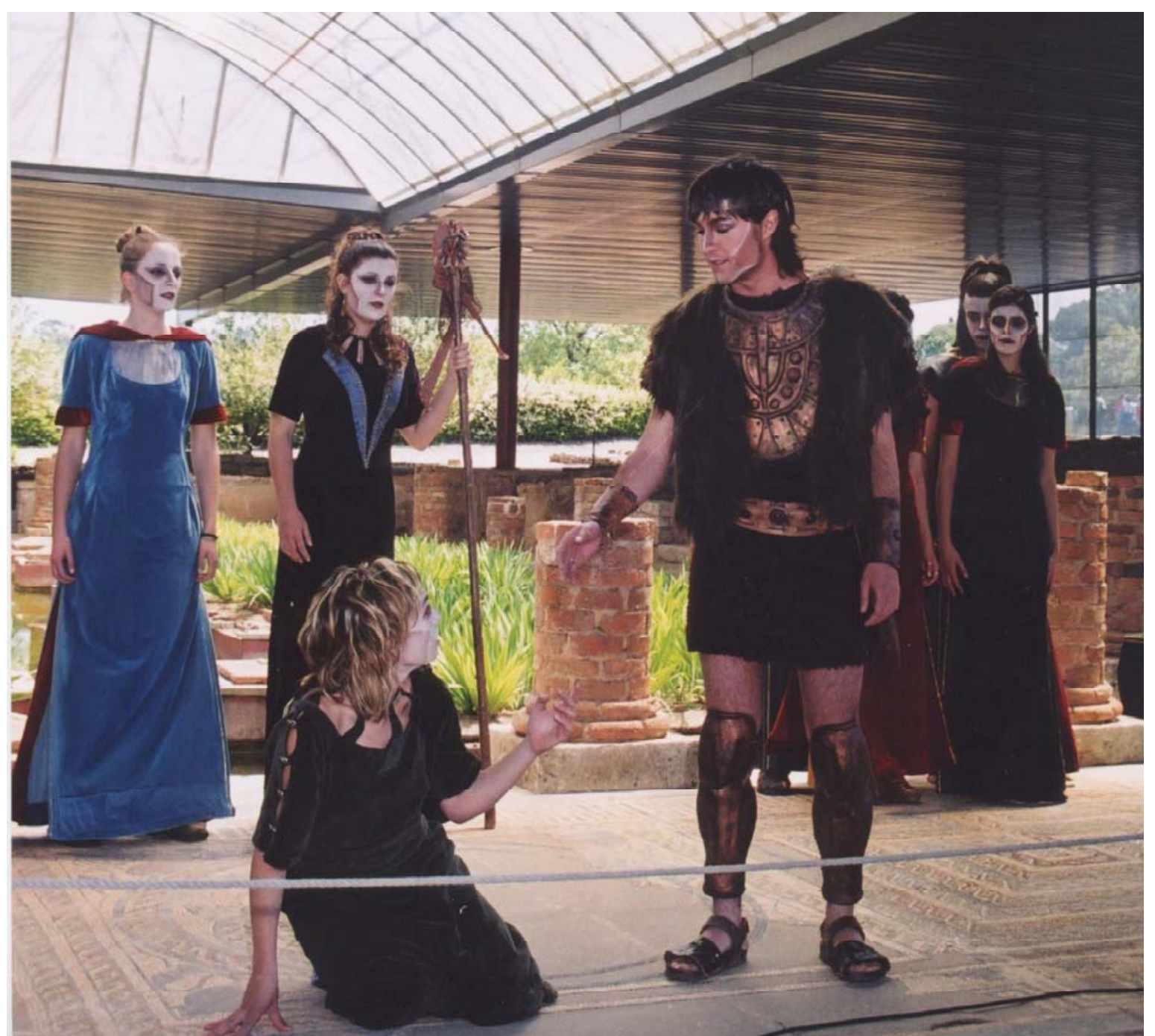

Electra, como leoa ferida, encarna as mais obscuras, violentas e elementares forças da natureza. Por seu lado, o irmão Orestes representa o modelo do herói apolíneo, forte e despreocupado, belo e cheio de luz, mesmo quando, cumprindo o oráculo de Apolo, mata a mãe para vingar o assassinato de seu pai.

Emvoltados dois irmãos movem-seas demais personagens, magistralmente caracterizadas, combinadas e dispostas por Sófocles dentro de uma acção dramática que, concebida como uma caçada, avança directamente para a armadilha final em que os assassinos pagarão o seu crime. Com a morte de Clitemnestra e do seu amante Egisto, resolve-se o conflito que abre e põe em marcha a tragédia: o crime tem de se pagar com o crime. A vingativa Némesis do morto fica assim aplacada.
A representação distingue-se pela movimentação do Coro que usa uma dupla máscara, provocando um efeito de surpresa, quando os coreutas se voltavam. Merece também realce o vestuário e a coreografia.

José Ribeiro Ferreira, in Maria de Fátima Silva (coord.), Representações de Teatro Clássico no Portugal Contemporâneo III (Coimbra 2004) 45.
Electra de Sófocles Conimbriga Fotos de José Batista 


\section{Lisístrata de Aristófanes \\ Grupo Calatalifa de Madrid}

\section{Encenação}

Pedro Sáenz de Almeida

Susana Verdú Martínez
A Lisístrata de Aristófanes foi apresentada em 411 a.C., nos últimos anos da Guerra do Peloponeso. Atenas estava em situação crítica: ainda não se recuperara da desastrosa campanha da Sicília (415-413 a.C.); os Espartanos, acampados a pouco mais de $20 \mathrm{~km}$, haviam concluído um acordo com o sátrapa persa Tissafernes e diversos aliados passavam para o lado do inimigo. A comédia, um ingénuo mas veemente apelo à paz, foi representada pela primeira vez nas Leneias sob o nome de Calístrato, o encenador da peça.

Nada sabemos a respeito do prémio obtido. As mulheres das cidades gregas envolvidas na Guerra do Peloponeso, lideradas pela ateniense Lisístrata, decidem instituir uma greve de sexo até que seus maridos parem a luta e estabeleçam a paz. No fim da peça, graças às mulheres, as duas cidades celebram efectivamente a paz.

do Programa
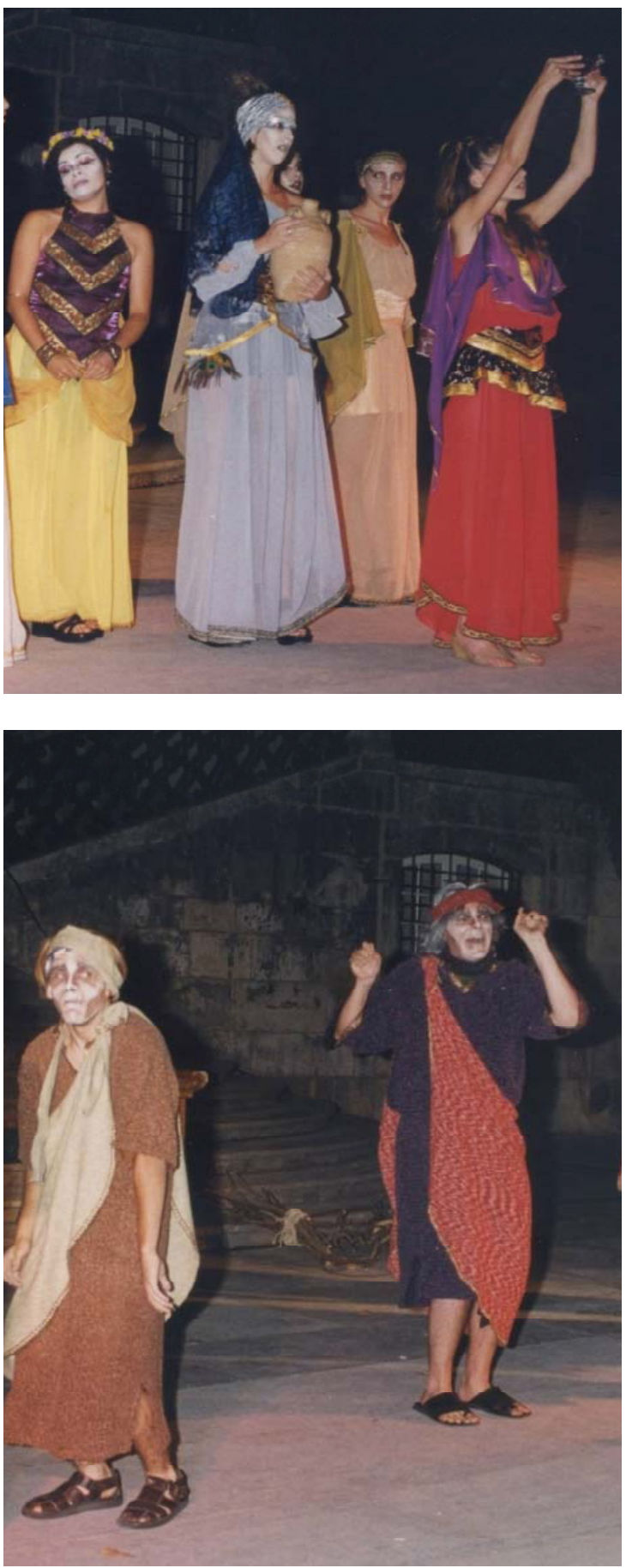

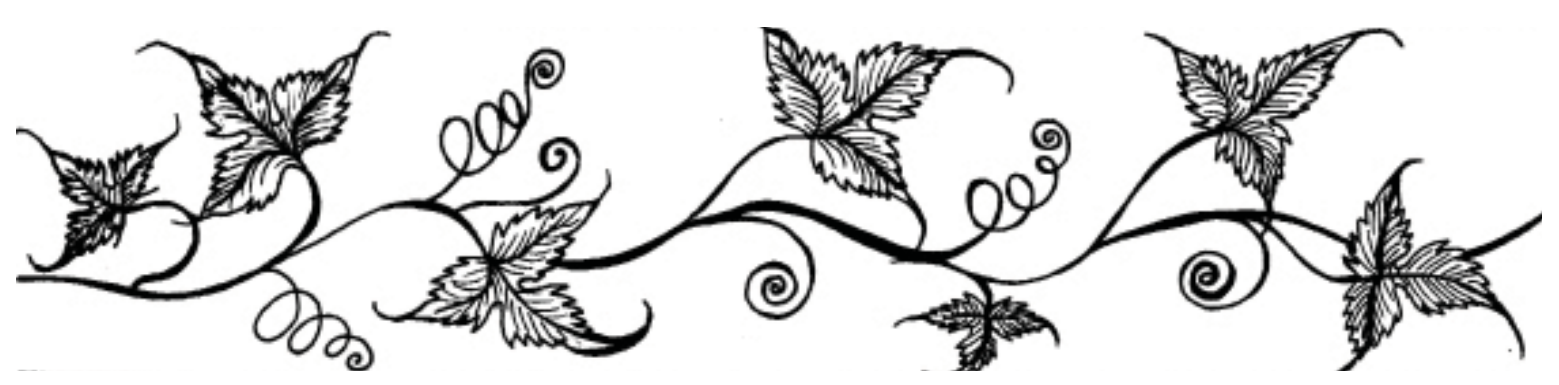




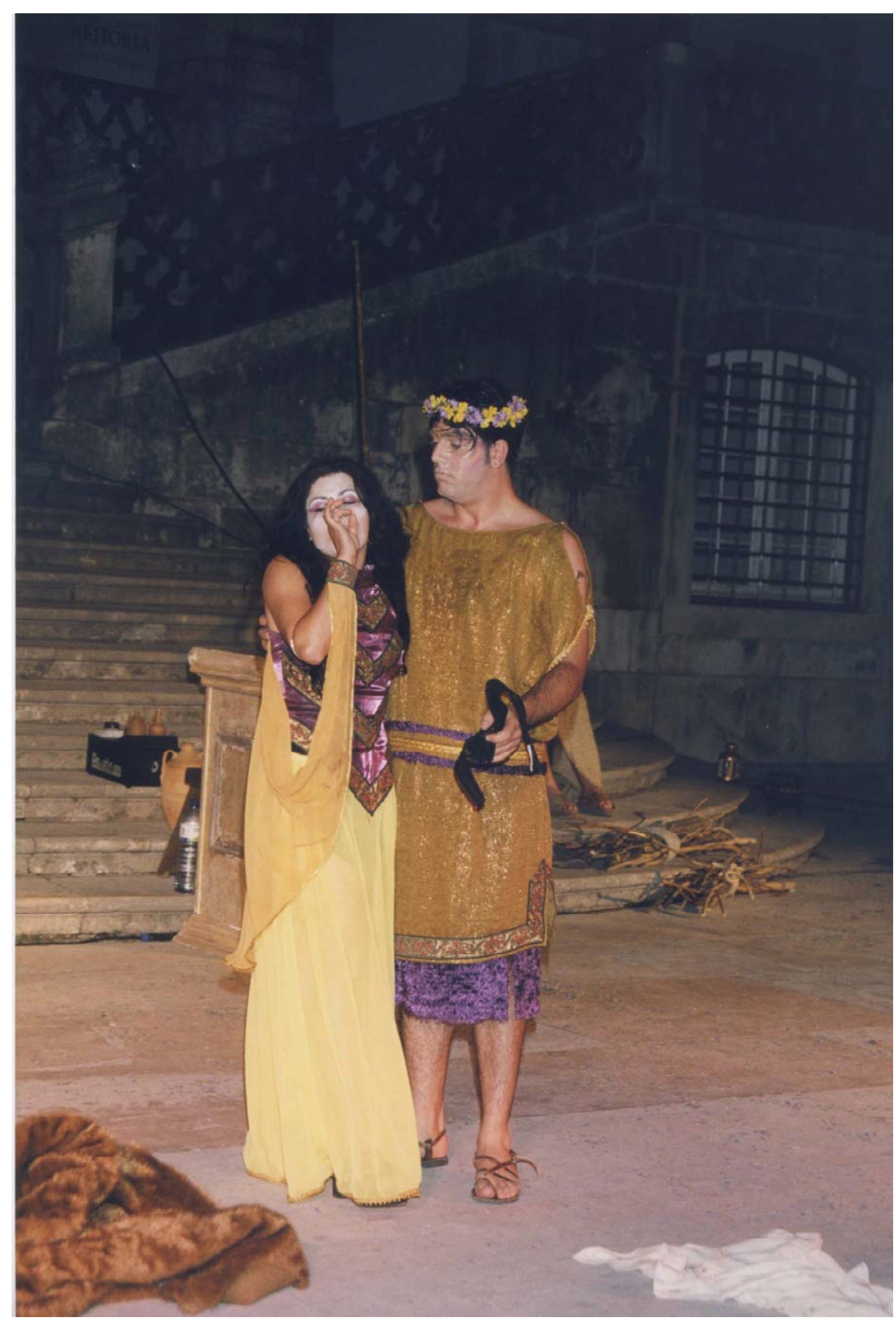

Lisístrata

de Aristófanes

Páteo da Universidade de Coimbra

Fotos de José Batista 


\section{Eunuco de Terêncio}

Grupo Calatalifa de Madrid

\author{
Encenação \\ Pedro Sáenz de Almeida \\ Música \\ Victor Carbajo \\ Figurinos \\ Araceli Lumbreras, \\ Ruth Patricia Sánchez \\ Cenografia \\ Juan Bayona, Miguel Cruz

\section{Coreografia \\ Karin Reitze \\ Elenco} \\ Susana Verdú Martínez (Taís) \\ Daniel Acebes Maya (Parmenão) \\ Nacho Negreiro Achiaga (Fédria) \\ Juan Bayona Segura (Trasão) \\ Luis Jiménez Ramos (Cremes)
}

Um dia a mãe da cortesã Taís, que morava em Rodes, recebeu uma criança ateniense, Pânfila, que ela educou como sua filha. Ao morrer, porém, o irmão, ganancioso, vendeu-a, por obra do acaso, ao soldado Trasão, que em tempos trouxera Taís para Atenas e aí lhe montara casa antes de regressar à Cária. O soldado viu nessa escrava uma óptima prenda para oferecer à sua amada Taís que estimava a jovem como irmã.
Vendo-se, porém, trocado por Fédria, ameaça só lhe entregar a moça se a cortesã continuasse a obsequiá-lo com os seus favores. Por isso Taís pede a Fédria, o seu novo amante, que por dois dias se ausente para o campo e não frequente a sua casa. Antes de partir, manda entregar à cortesã um eunuco que comprara. Um efebo, Quéreas, irmão de Fédria, perdidamente apaixonado pela jovem enviada de presente a Taís, veste a roupa do eunuco, a conselho do escravo Parmenão, introduz-se na casa e viola a donzela. Depois de várias e movimentadas peripécias, em que o verdadeiro eunuco é interrogado e ameaçado por Fédria, com os inerentes quiproquós, e em que o soldado quer reaver a escrava que dera de presente, após desentendimento com Taís, um cidadão ateniense, Cremes, o verdadeiro irmão de Pânfila, dá a jovem em casamento a Quéreas, uma vez comprovado o reconhecimento.

Estamos perante uma comédia marcada por grande vivacidade e comicidade, o que não é vulgar nas peças de Terêncio. O autor soube retratar as principais personagens de forma subtil e viva, realçando as fraquezas humanas de modo divertido.

José Ribeiro Ferreira, in Maria de Fátima Silva (coord.), Representações de Teatro Clássico no Portugal Contemporâneo III

(Coimbra 2004) 151.

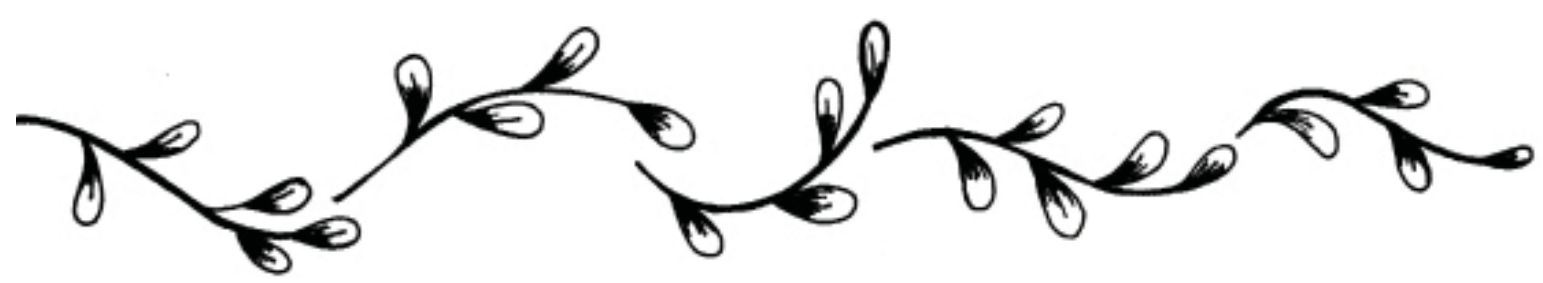




\section{Electra de Eurípides}

Grupo Sardiña do IES Elpiña da Corunha

\section{Encenação}

Beatriz Martín

J. Ricardo Martín

\section{Luzes}

Iria Catoira

\section{Banda sonora original}

Alfonso R. Molares

\section{Som}

Vanessa Gómez

\section{Elenco}

Lucía Regueiro (Electra)

Alfonso R. Molares (Lavrador)

José Luís López (Orestes)

Mário López (Ancião)

\section{Coro}

Tâmara Canosa (Corifeu), Marta Ramos, Alba Gómez, Cira Sánchez, Noemi Palias, Sónia Candal, Iria Veigela, Tâmara Cotelo,

Vanessa Pérez, Yolanda Espasandín,

Tâmara Sánchez
Assassinado Agamémnon por Clitemnestra e seu amante Egisto, seu filho Orestes, ainda criança, teve de fugir para o exílio e sua filha Electra foi desterrada para os confins do reino, casada com um lavrador, já idoso, para evitar uma descendência que possa vingar a morte do rei. Embora a princesa chore a sua desgraça, alimenta a esperança de que o irmão regresse e castigue os culpados. De facto assim acontece. E, no plano de vingança, Electra desempenha o principal papel.

Em Eurípides, Electra é fria, calculista; tece ela própria a teia do assassínio de Egisto e da mãe, ainda que tenha de dobrar a vontade do irmão.

José Ribeiro Ferreira, in Maria de Fátima Silva (coord.), Representações de Teatro Clássico no Portugal Contemporâneo III Coimbra 2004) 61.

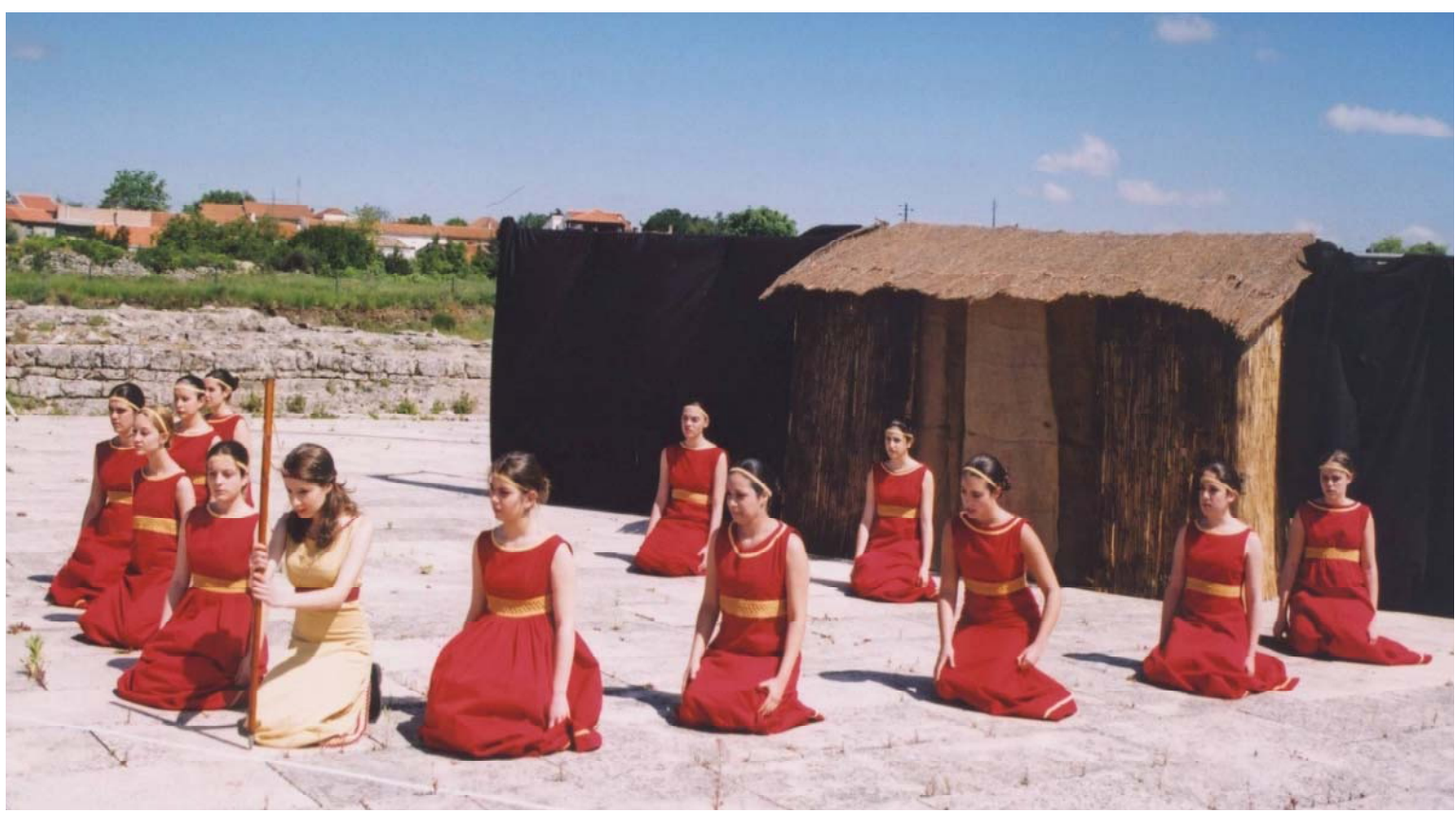

Electra de Eurípides Conimbriga Fotos de José Batista 


\section{Os Dois Menecmos de Plauto \\ Grupo Sardiña do IES Elpiña da Corunha}

\section{Encenação \\ Beatriz Martín, J. Ricardo Martín}

Os dois Menecmos, tal como o Anfitrião e, em parte, o Soldado Fanfarrão, são uma peça cujo cómico resulta, principalmente, do sucessivo aparecimento em cena dos simillimi: dois gémeos, ambos com o mesmo nome, que, não se conhecendo por terem vivido separados desde os sete anos, um em Siracusa, outro na cidade Epirota de Epidamno, acabam por se encontrar, já homens feitos. É este o tema central - quase diríamos, linear - da comédia. Mas a simplicidade do enredo é perturbada, desde o início da peça, pelo facto de os dois gémeos serem tão parecidos, que nem a ama, que lhes dera o seio, nem a mãe, que os gerara, seriam capazes de os diferenciar. (...)

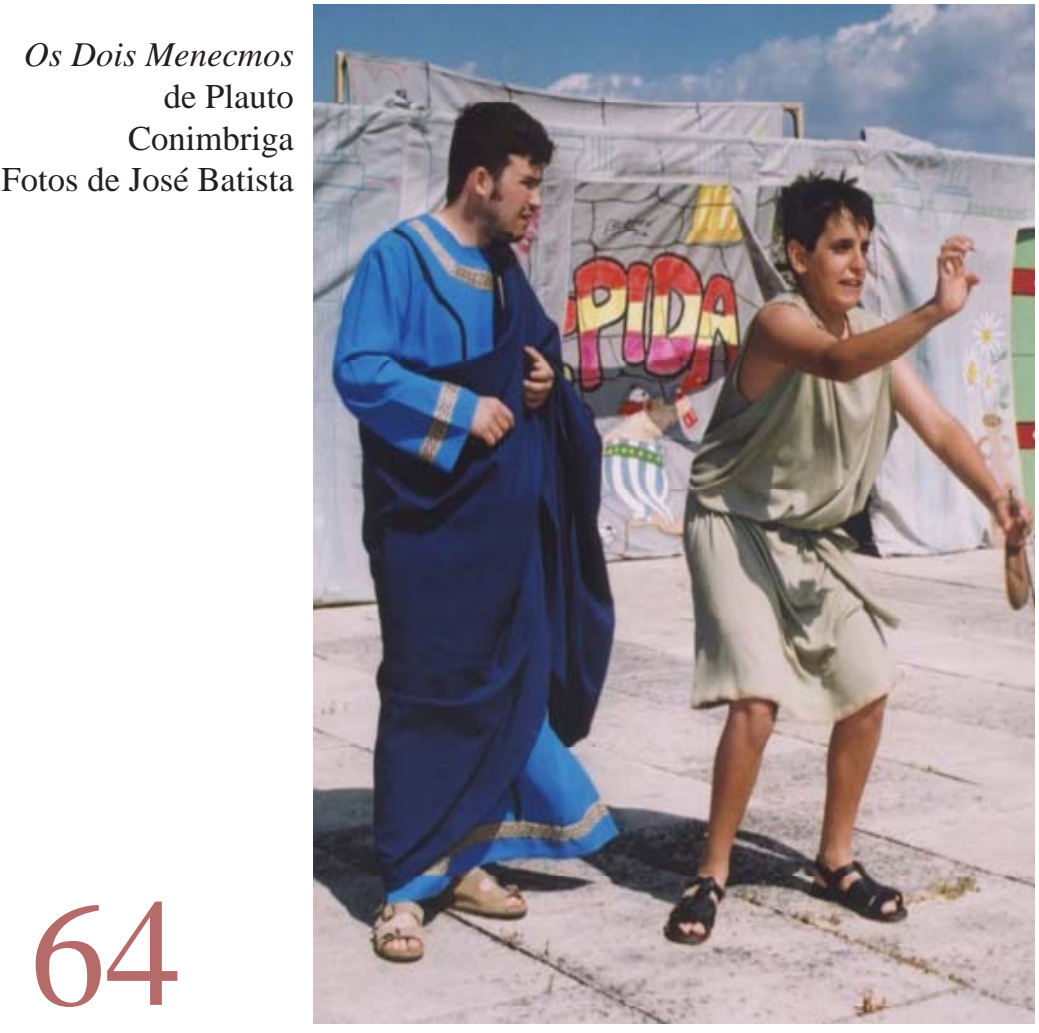

Assim, quando começa a acção, o Menecmo de Siracusa acaba de chegar a Epidamno, onde vive há muitos anos o outro Menecmo, rico e casado com uma mulher difícil. E é aqui que começam as complicações. O Menecmo de Epidamno engana a esposa com uma vizinha, Erócio, mulher de porta aberta. Ao saber disto, a matrona enfurece-se e as recriminações chovem sobre... o inocente e recém-chegado Menecmo de Siracusa, que se vê, diversamente, alvo das atenções de duas desconhecidas: de uma que, tratando-o de marido, o insulta; da outra que, chamando-lhe seu amante, o acarinha.

Por fim, tudo acaba em bem: após uma longa cena, repetitiva, que muito tem que ver com uma acareação judicial, os dois irmãos reconhecem-se e abraçam-se num bem característico "happy ending”.

Carlos A. Louro Fonseca (da Introdução à tradução)

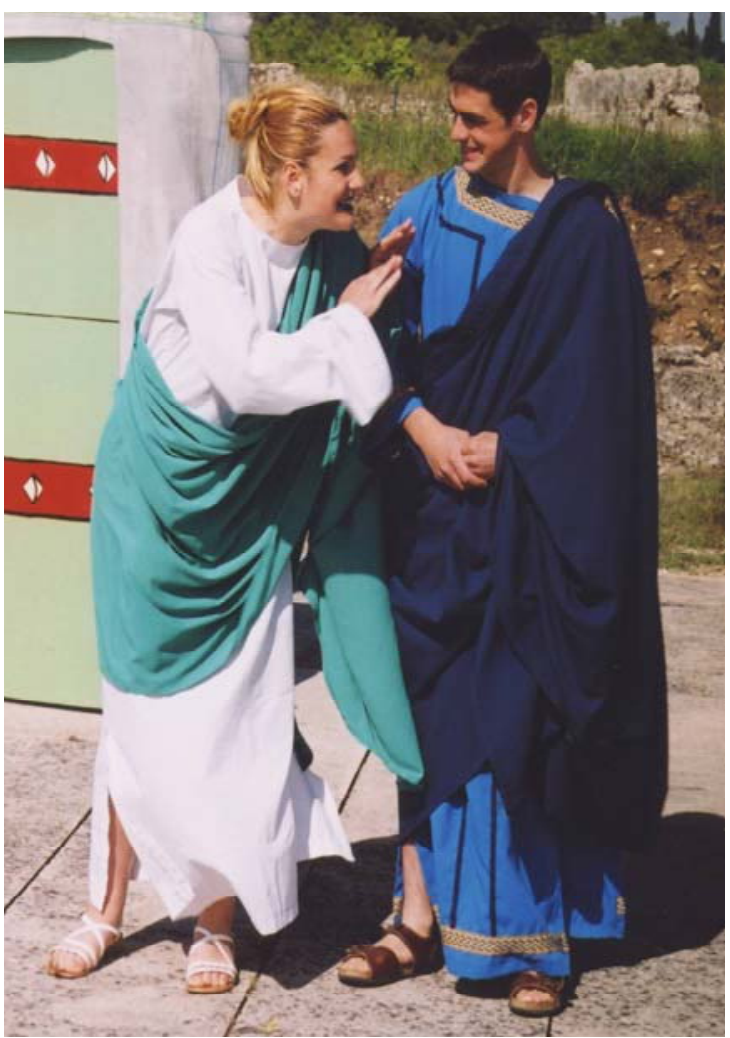




\section{Antígona de António Pedro}

Grupo Teat $\AA$ amus

Núcleo de Teatro do Colégio de Calvão

\section{Encenação}

Filipe Jorge, Patrícia Martins

Direcção de Actores

Filipe Jorge, Patrícia Martins

\section{Cenografia}

Carlos Jesus, alunos do Agrupamento 2

Guarda-Roupa

D. Rosa

Iluminação

Pedro Neto

\section{Composição Musical}

Paulo Henrique, Pedro Neto,

Fernando Ferreira

Elenco

Carla Rosete (Antígona)

António José Simões (Creonte)

Sara Leigo (Isménia)

Ângelo Valente (Tirésias)

Lilibel Valente (Eurídice)

Bianca Barros (Artemísia)

Carlos Carvalhais (Hémon)

João Vítor (Soldado 1)

Pedro Reis (Soldado 2)

Coro

Carina Alves, Simone Miranda,

Susana Diamantino
Formado há aproximadamente nove anos com o propósito de oferecer aos jovens alunos do Colégio de Calvão um complemento de formação teatral e de, por esse meio, concorrer também para a ocupação dos seus tempos livres, o Teat ${ }^{\circledR a m u s}$ ostenta já um repertório digno de menção, que inclui representações de várias peças, das quais se destacam $O$ Rouxinol e a Rosa, A Canção de Natal, Romeu e Julieta, O Principezinho, A Gota de Mel, Guerra Santa, Antígona e Rei Édipo.

Para a sua primeira experiência de representação de teatro de tema clássico, a peça eleita foi a Antígona, levada à cena pela primeira vez, no Colégio de Calvão, a 21 de Abril de 2002. Não a Antígona sofocliana, mas a recriação que dela fez António Pedro, uma "Glosa Nova” escrita expressamente para ser representada pelo Teatro Experimental do Porto, na década de 50, com uma linguagem actual e dramaticamente funcional muito apreciada, que fez com que se tornasse na mais representada das recriações portuguesas da Antígona de Sófocles.

Com uma adequada encenação da responsabilidade de Filipe Jorge e de Patrícia Martins, a peça, depois da estreia e de duas representações em Escolas do distrito de Aveiro, abriu o IV Festival Internacional de Verão de Teatro de Tema Clássico, em Conímbriga, a 22 de Junho de 2002.

Carlos Morais, in Maria de Fátima Silva (coord.), Representações de Teatro Clássico no Portugal Contemporâneo III

(Coimbra 2004) 40.

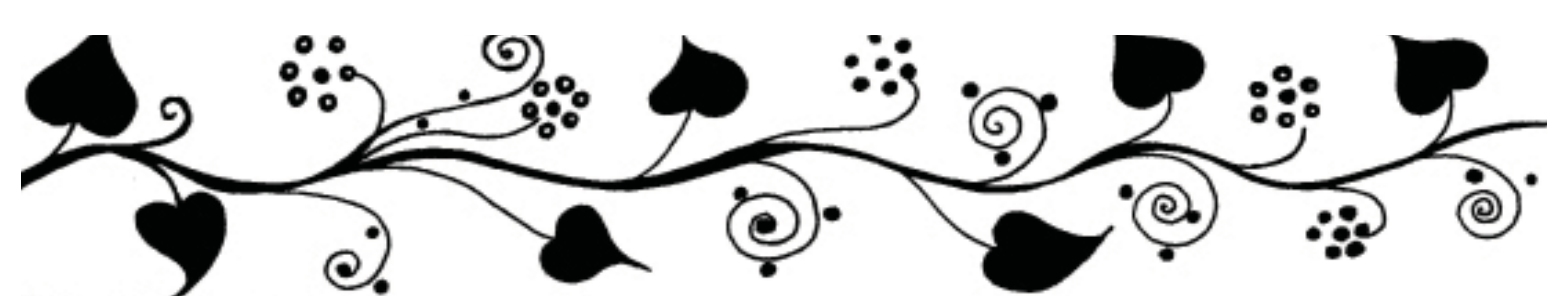




\section{Comédia do Fantasma de Plauto}

\author{
Grupo Balbo
}

de Puerto de Santa María (Cádis)

\section{Encenação}

Emilio Flor Jiménez

\section{Adereços e vestuário}

Trabalho de grupo

Director Técnico e de Luzes

Joaco Arjona Cabrera

Som

Antonio Pecho Martin

Elenco

Javier Ortega Jaén,

Esther Pumar Reyes (Tranião)

Fátima Jimenez Enrique,

Maria Serpa Mora (Grumião)

Jesus María Gutierrez Torres,

Patrícia Lopez Ocafia (Filólaques)

Elisabeth Mena Linder,

Ines Higueras (Filemácio)

Margarita Dominguez Sanchez,

Libertad Marin Rueda (Escafa)

Antonio Zarola Ortiz,

Adrian Varo Garcia (Calidamates)

Esther Pumar Reyes,

Maria Serpa Mora (Délfio)
Eva María Rodriguez Cruz, Jesus María Gutierrez Torres (Teoprópides)

Fátima Jimenez Enrique (Misargírides)

Marcos Collado Martin,

Enrique Lainer (Simão)

Rocio Garcia Heredia (Mulher de Simão)

Valentín Murillo Romero,

Maria Serpa Mora (Fanisco)

Juan Lorca Mufioz (Pinácio)

Maria Serpa Mora, Juan Lorca,

Regina Carballo Lopez,

Maria Torres (Cupidos)

Zoraida Valiente Rodriguez,

Carmen Clara Ciria Rosello, Maria Serpa

Mora, Libertad Marin Rueda, Regina Carballo

Lopez, Maria Reyes, Aida, Rocio Lainer,

Maria Torres (Marinheiros e Prostitutas)

O Balbo propõe ao público, uma satura composta por comédia musical, ópera cómica, canto, opereta, música, interlúdios musicais, baile, dança, gracejos, gesticulação exagerada e ritmo frenético. A liberdade cómica ainda permitiu ao grupo dispor de actores-mimos que, embora ausentes do texto da peça, reflectem a

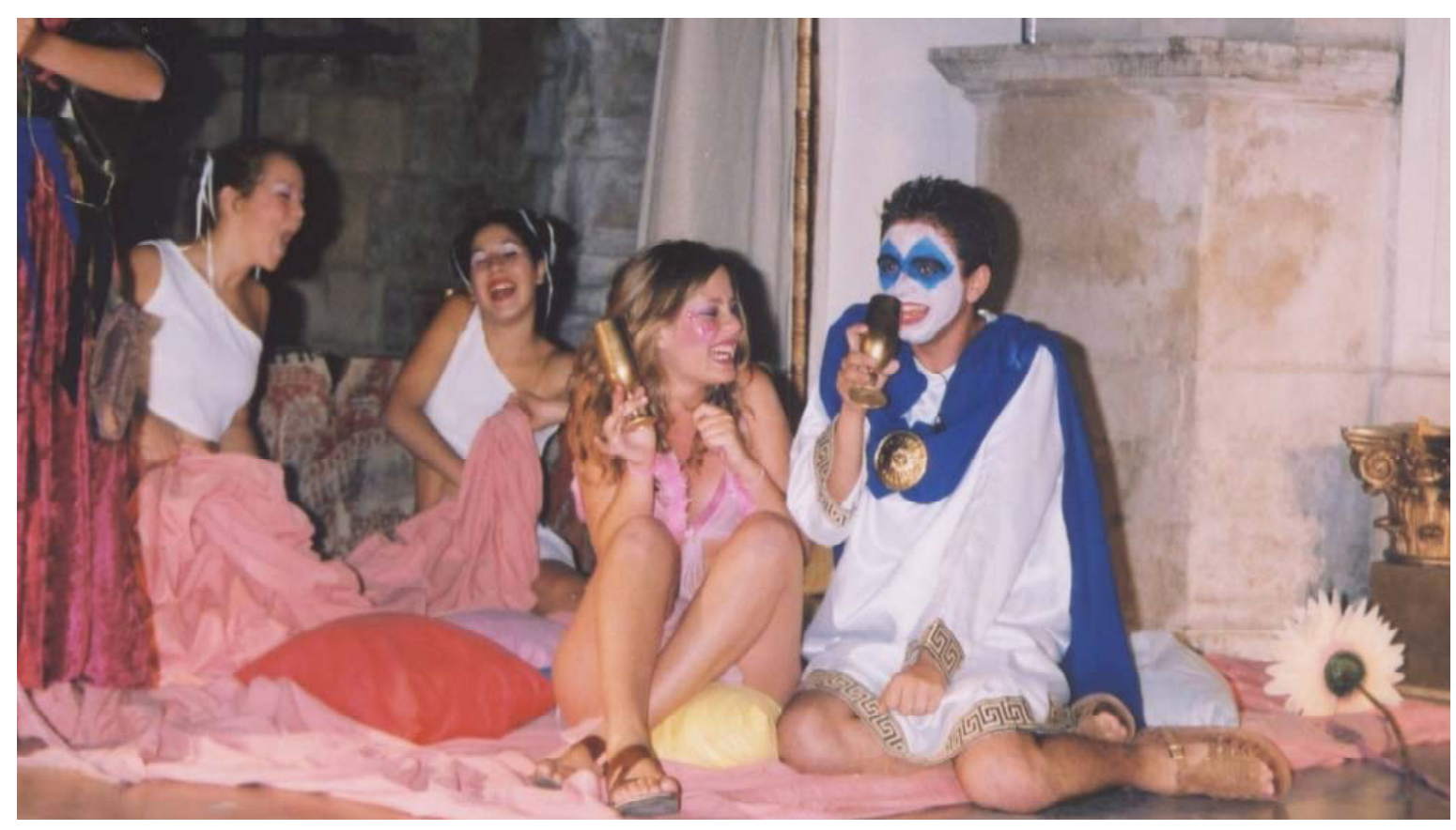


grande adesão dos alunos a este tipo de projecto e, de algum modo, enriquecem o próprio cenário.

Em alguns momentos, houve necessidade de adaptar a própria tradução, de modo a transmitir, de forma mais eficaz e clara, a riqueza e o lirismo do original. O canto, além de evitar a monotonia, realça os momentos mais importantes.

O Balbo pretende que os alunos que assistam à peça reconheçam "la tipificación elemental de los personajes, el movimiento (comoedia motoria), la perdida de la ilusión escénica, los equívocos linguísticos y de situaciones, el juego de palabras, el habla popular, el italum acetum, la grosería, la tramoya, vestimenta exagerada, el sabor rural, la crítica social velada, la ausência de contenido político, la falta de estúdio psicológico de los personajes, la contaminatio, la pantomima, la vivacidad en el diálogo y en las acciones, los diverba, los cantica."

O grupo não deixa ainda de advertir o público de que a improvisação, fruto do contacto com os espectadores, estará pontualmente presente no espectáculo. Alguma reacção do público estava, de resto, pressuposta nas palhaçadas, nos pedidos de silêncio ou de colaboração dirigidos aos espectadores romanos, nas reiteradas advertências, na captatio beneuolentiae dos prólogos, nas alusões à actualidade, nas repetições e nas zombarias do escravo. Nessa interacção frequente entre actores e espectadores, a plebe romana chegava a ser a actriz principal.

O espectáculo teve, efectivamente, muita cor, luz, ritmo, canto e dança. Entre os actores, importa destacar o desempenho de Javier Ortega Jaén, que foi um Tranião cheio de carisma, astúcia e poder de improvisação, como convém a um escravo plautino que se preze.

Paulo Sérgio Ferreira, in Maria de Fátima Silva (coord.), Representações de Teatro Clássico no Portugal Contemporâneo III (Coimbra 2004) 143-145.

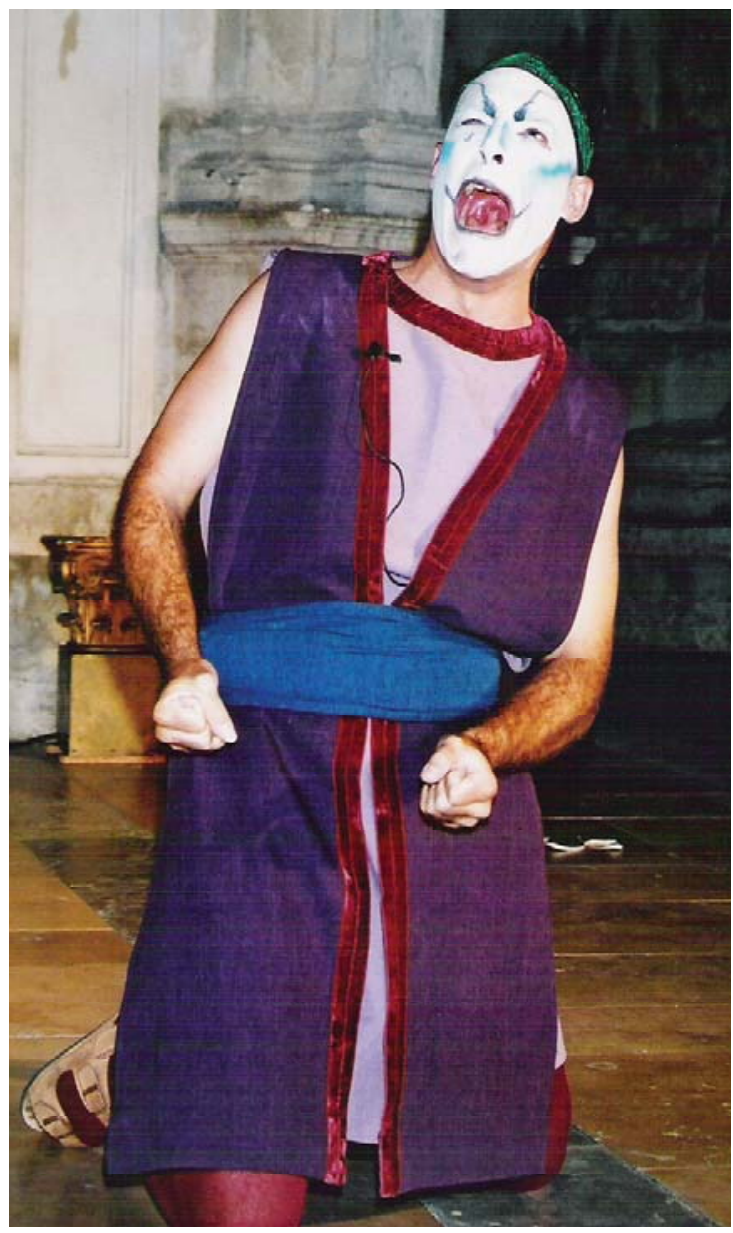

Comédia do Fantasma de Plauto Praça 8 de Maio (Coimbra) Fotos de José Batista 


\section{FESTIVAL DE VERÃO \\ DE TEATRO DE TEMA CLÁSSICO}

10 de Junho de 2003, 17.30 horas, Conimbriga

O Corpo de Helena de Paulo José Miranda, grupo Ágon das Caldas da Rainha

26 de Junho de 2003, 21.45 horas, Museu Nacional Machado de Castro

O Corpo de Helena de Paulo José Miranda, grupo Ágon das Caldas da Rainha

4 de Julho de 2003, 22.30 horas, Centro de Arte e Espectáculos da Figueira da Foz As Traquínias de Sófocles, grupo Thíasos do IEC

5 de Julho de 2003, 21.45 horas, Museu D. Diogo de Sousa (Braga)

Anfitrião de Plauto, grupo Thíasos do IEC

7 de Julho de 2003, 21.45 horas, Museu D. Diogo de Sousa (Braga)

Antígona de Sófocles, grupo Balbo do IES de Puerto de Santa María (Cádis)

8 de Julho de 2003, 21.30 horas, Páteo da Universidade de Coimbra

Antígona de Sófocles, grupo Balbo do IES de Puerto de Santa María (Cádis)

10 de Julho de 2003, 22.00 horas, Antigo Mercado (Viseu)

A Comédia do Fantasma de Plauto, grupo Balbo do IES de Puerto de Santa María (Cádis)

11 de Julho de 2003, 22.30 horas, Centro de Arte e Espectáculos da Figueira da Foz

A Comédia do Fantasma de Plauto, grupo Balbo do IES de Puerto de Santa María (Cádis)

12 de Julho de 2003, 20.00 horas, Páteo da Universidade de Coimbra

A Comédia do Fantasma de Plauto, grupo Balbo do IES de Puerto de Santa María (Cádis)

16 de Julho de 2003, 21.30 horas, Claustros da Sé Velha de Coimbra

As Traquínias de Sófocles, grupo Thíasos do IEC
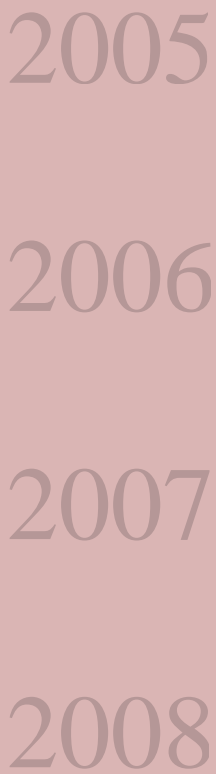


\section{Comemoração do centenário do nascimento de Sófocles}

Em 2003 decorreu o 25 centenário do nascimento de Sófocles, um dos principais e mais influentes tragediógrafos da Grécia antiga. Para comemorar essa efeméride foi organizado um Festival Internacional de Teatro, no qual foram apresentadas tragédias do referido dramaturgo, ou espectáculos com ele relacionados.

Parte integrante da cultura de hoje, os temas e mitos greco-romanos são utilizados, a cada passo, por autores contemporâneos para darem corpo a valores e ideais do homem da actualidade. A cultura clássica criou valores intrínsecos de grande relevância que, transmitidos ao longo dos tempos, estão na base do viver e sentir do homem moderno: em especial deram forma à cultura ocidental e nela permanecem pujantes e vivos. E nesse processo exerceu papel de relevo o teatro.

A tragédia, que buscava preferentemente os seus assuntos na tradição lendária dos heróis ou dos deuses, equacionava perante o público problemas das relações do homem com os deuses (por exemplo, casos de piedade e de insolência), situações de medição das forças humanas com as do destino e problemas de relações dos homens entre si, ou seja questões de justiça.

Sófocles foi um dos que mais influência exerceu e continua hoje presente na cultura e literatura. Muitas das suas figuras - como Édipo, Antígona, Clitemnestra, Orestes, Electra, Filoctetes, Ájax, Ulisses - continuam vivas e tornaram-se símbolos ou paradigmas.

\section{Vestuário, adereços e objectos nas tragédias de Sófocles}

\author{
Exposição integrada no colóquio
}

"25 séculos do nascimento de Sófocles"

(de 27 de Novembro a 14 de Dezembro de 2003)

Organização

Instituto de Estudos Clássicos da Universidade de Coimbra

Festea-Tema Clássico

Centro de Estudos Clássicos e Humanísticos da Universidade de Coimbra

\section{Apoios}

Coimbra Capital Nacional da Cultura 2003 Reitoria da Universidade de Coimbra

IES Carlos III de Madrid

\section{Concepção, direcção e desenho do vestuário Gemma López Martínez \\ Assistência científica José Luis Navarro}

José Ribeiro Ferreira

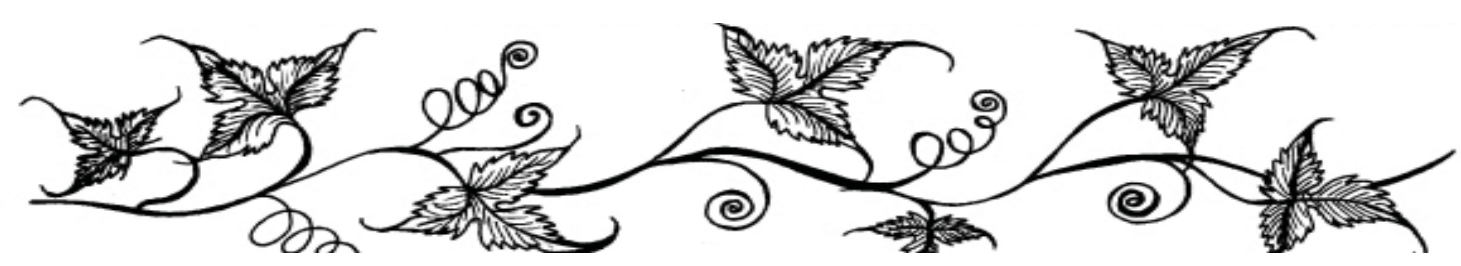


XXV CENTENÁRIO DO NASCIMENTO DE SÓFOCLES

\section{Vestuário, adereços e objectos nas tragédias de Sófocles}

Sala do Exame Privado - ReItoria da Universidade de CoImbra De 27 de Novembro a 14 de Dezembro de 2003

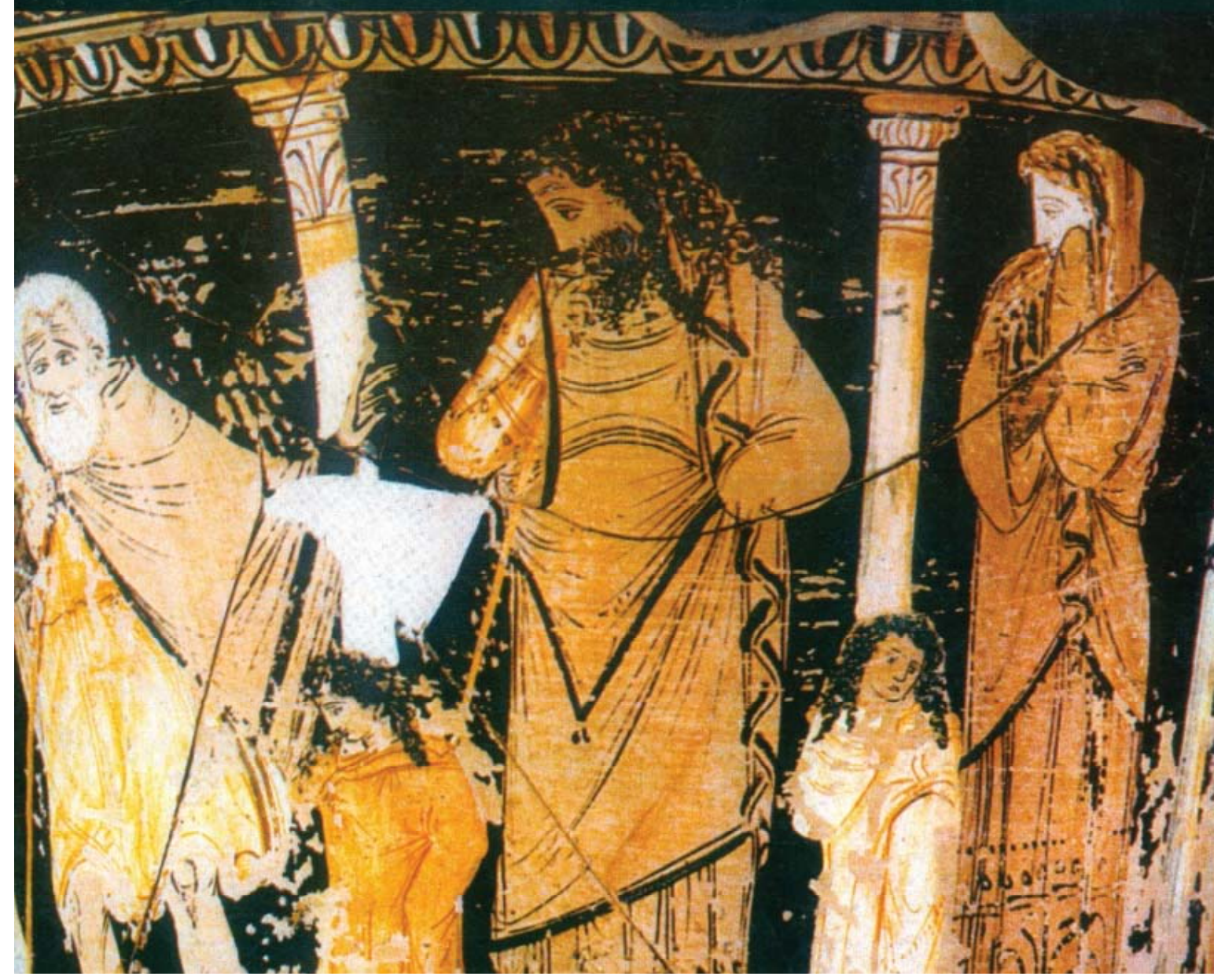




\section{Traquínias de Sófocles}

Grupo Thíasos do IEC

\author{
Tradução \\ Maria do Céu Fialho \\ Encenação \\ Delfim Ferreira Leão \\ Direç̧ão de actores \\ Victor Torres \\ Coreografia \\ Carla Braz

\section{Guarda-roupa}

Luísa de Nazaré Ferreira, Maria Valente, Inês Santos

Sonoplastia e iluminação

Carlos Santos, Isidro Alves, Carlos Jesus Elenco

Elisa Bogalheiro, Patrícia Santos (Dejanira)

Amélia Álvaro de Campos,

Sofia Costa, Natália Alves (Ama)

Nuno Gertrudes (Hilo)

José Luís Brandão (Mensageiro)

Bruno Fernandes (Licas)

Delfim Leão, Luís Marques Cruz (Héracles)

Manuel Santos, Joaquim da Silva (Figurantes)

\section{Coro}

Carla Braz, Carla Simões, Carla Marques,

Liliana Dias, Liliana Figueiredo, Lia Nunes,

Natália Alves, Patrícia Ferreira, Silvia Costa,

Sónia Santos, Susana Bastos,

Verónica Fachada
Com esta produção, o Thíasos ensaia, pela segunda vez, os caminhos da tragédia grega. Como linha orientadora da encenação, foi adoptada a imagem do fogo, enquanto metáfora da paixão que avassala as personagens centrais (Dejanira e Héracles) e também como símbolo da própria destruição que se abatera sobre o herói dos doze trabalhos (primeiro no manto oferecido por Dejanira e, por último, na pira final).

A ambivalência deste poderoso signo marca a própria caracterização do coro, cujo vestuário procura sugerir as cores instáveis do fogo. De resto, ao coro cabe a função de narrar e sublinhar (com menos texto e mais recurso a música e a coreografia) parte do drama que será vivido pelo par Dejanira/Héracles. Desta forma, é o Coro quem verdadeiramente inicia a peça, através de uma dança que procura sugerir a ideia de uma relação amorosa que se vai construindo através do cruzamento de passos e de gestos, até que se instala a sombra da separação. Só quando o Coro se anula (como se todos os seus elementos fossem estátuas de um jardim) é que entra Dejanira, expondo à Ama as apreensões que traz na alma.

Toda a movimentação do Coro visa obedecer ao objectivo de fornecer um subtexto capaz de criar no espectador vários níveis de leitura. Por esse motivo, as posições assumidas procuram evocar motivos da escultura grega (as Cariátides, a Vitória de Samotrácia, o friso

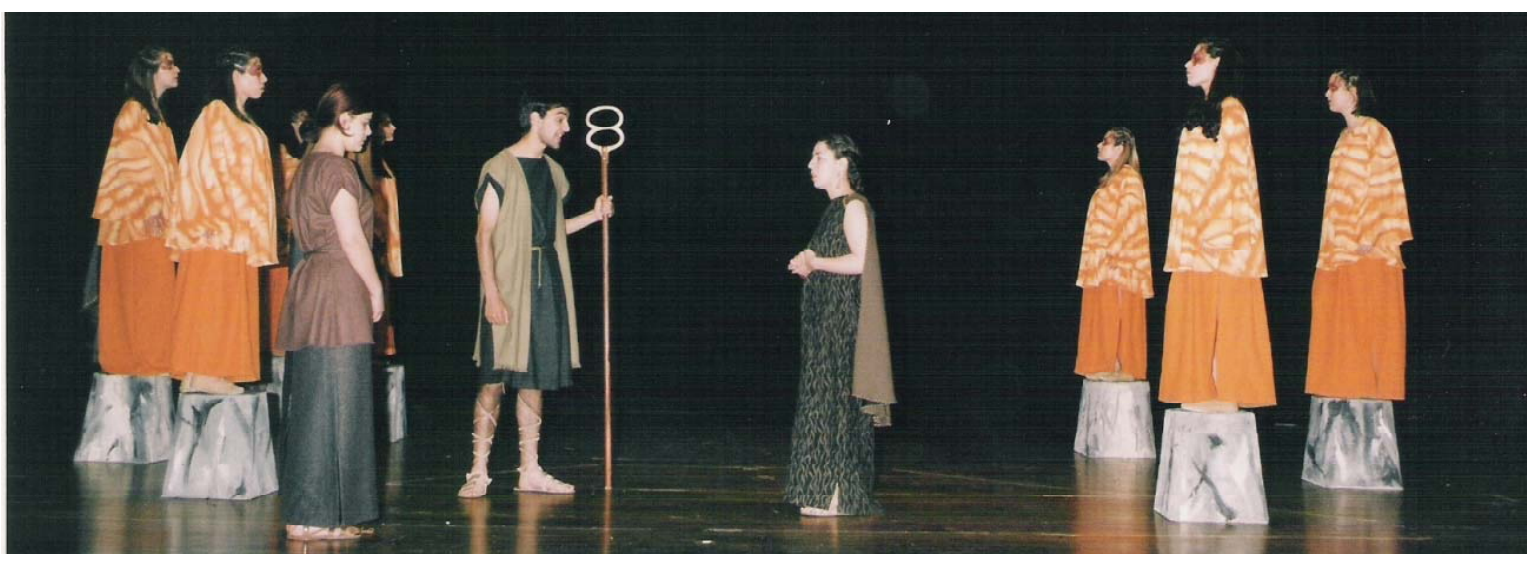




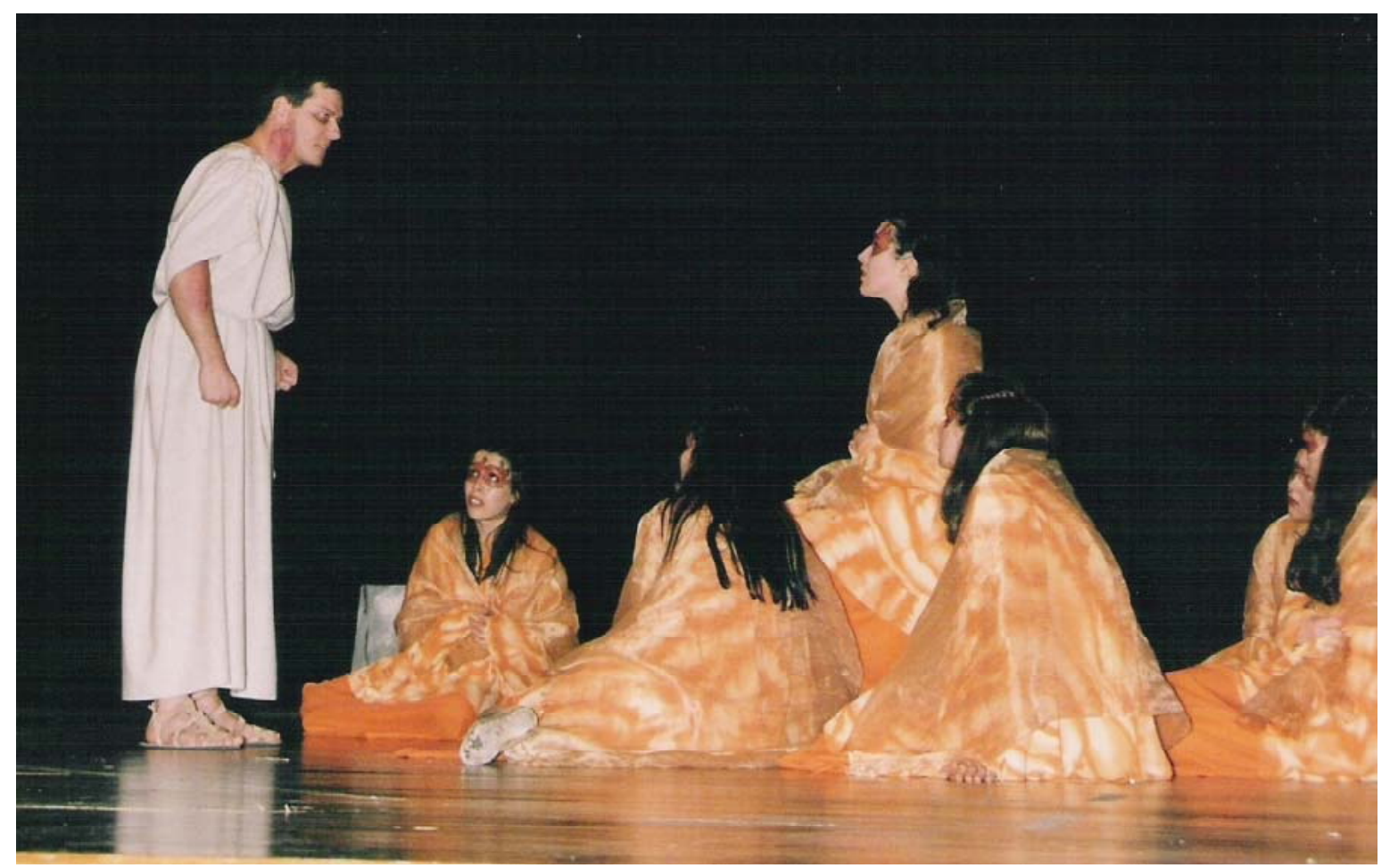

de um templo), numa metamorfose constante que serve ora de comentário ora de reforço à linha de acção. O mesmo objectivo se pretende com os apontamentos de cenário (oito blocos quadrangulares), que funcionam como bases de estátuas, bancos de juízes ou ainda como a lenha da pira que há-de evocar a imolação de Héracles, na cena final, em que os mantos e as próprias jovens de Tráquis se transformam no fogo que devora o herói grego, até se debulharem no chão, como cinza ainda quente.

A aposta forte na música e em evoluções coreográficas, que aparece agora, e pela primeira vez, como uma das opções de fundo numa encenação do Thíasos, procura ir ao encontro de uma concepção do teatro grego enquanto forma de arte que vive muito da palavra, mas tambem da música, do canto e da dança.

Delfim Ferreira Leão, in Maria de Fátima Silva (coord.), Representações de Teatro Clássico no Portugal Contemporâneo III (Coimbra 2004)

52-53.

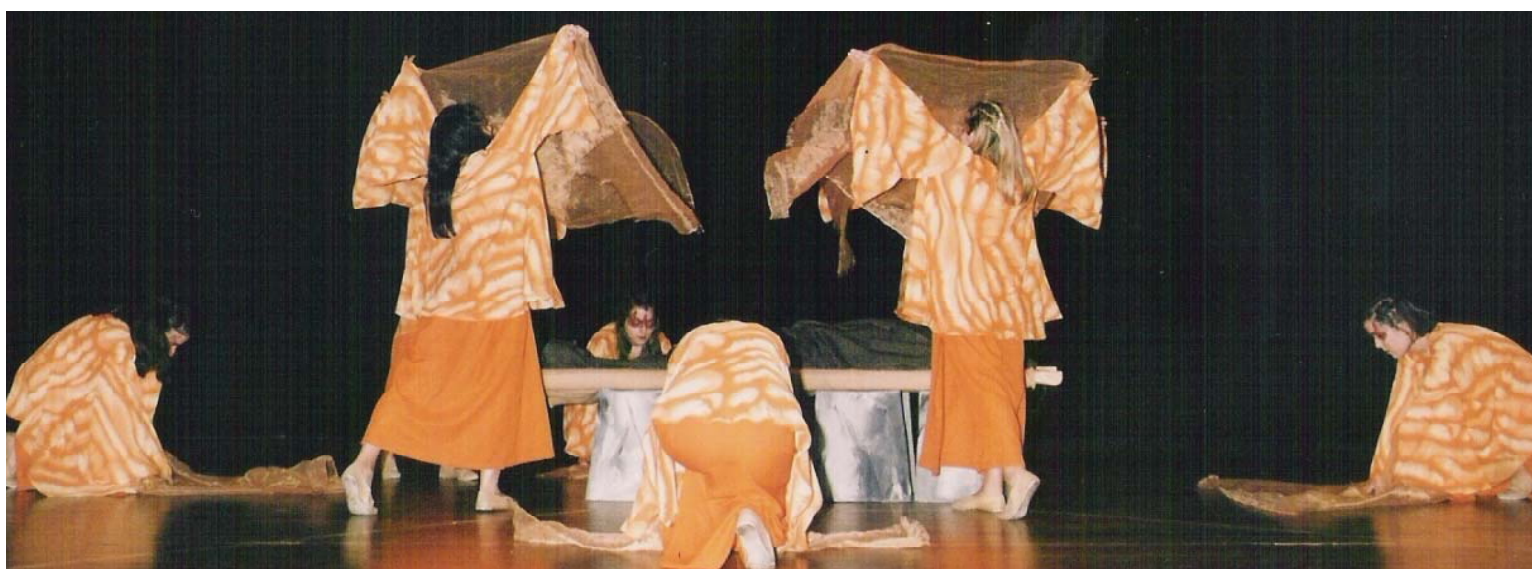

Traquínias de Sófocles Colégio de S. Teotónio Fotos de José Batista

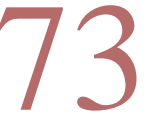




\section{Rei Édipo de Sófocles}

Grupo Teat ${ }^{\circledR}$ amus

Núcleo de Teatro do Colégio de Calvão

Tradução

Maria do Céu Fialho

Encenação

Filipe Jorge e Jorge Carvalhais

Cenografia

Alunos do Agrupamento 2

Guarda-roupa

D. Rosa

Iluminação

Paulo Henrique, Pedro Neto

Composição musical

Paulo Henrique, Pedro Neto, Fernando Ferreira

\section{Elenco}

Carlos Carvalhais (Édipo)

Simone Miranda (Jocasta)

Jorge Carvalhais (Creonte)

Filipe Jorge (Tirésias)

Sara Leigo (Sacerdote)

Bianca Barros (Mensageiro de Corinto)

Janette Ferreira (Mensageiro do Palácio)

Rosa Pequeno (Servo)

Pedro Reis (Soldado)

Daniela Simões (Antígona)

Michelle Rita (Ismena)

\section{Coro}

Carina Alves, Susana Diamantino, Ana Oliveira, Ana Cláudia Cruz,

Neide Almeida, Lucia Silva, Márcia Balseiro

Para os encenadores (e também actores), os professores Filipe Jorge e Jorge Carvalhais, o desafio de apresentar um texto com a forte carga simbólica e emotiva como o do Rei Édipo de Sófocles constituiu uma enorme responsabilidade. Secundados entusiasticamente pelos professores de Latim e de Grego do Colégio, quiseram recriar este clássico sofocliano. A estreia ocorreu "em casa”, na noite do dia 2 de Maio de 2003. Estiveram presentes cerca de duas centenas de pessoas. Servindo-se de um elenco de dezanove elementos, todos eles alunos do Colégio, e estudantes dos Agrupamentos I, 2, e 4, com indumentárias e cenários inteiramente criados para o efeito, o espectáculo decorreu, como pensado e desejado, ao ar livre, em noite primaveril.

Mário Paulo Martins, in Maria de Fátima Silva (coord.), Representações de Teatro Clássico no Portugal Contemporâneo III (Coimbra 2004) 49.

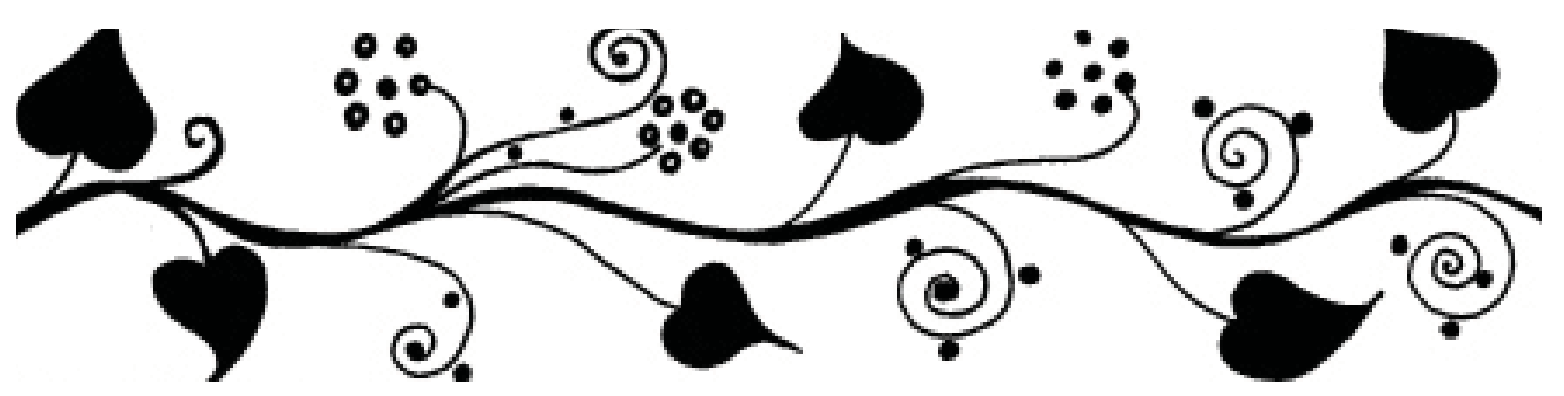



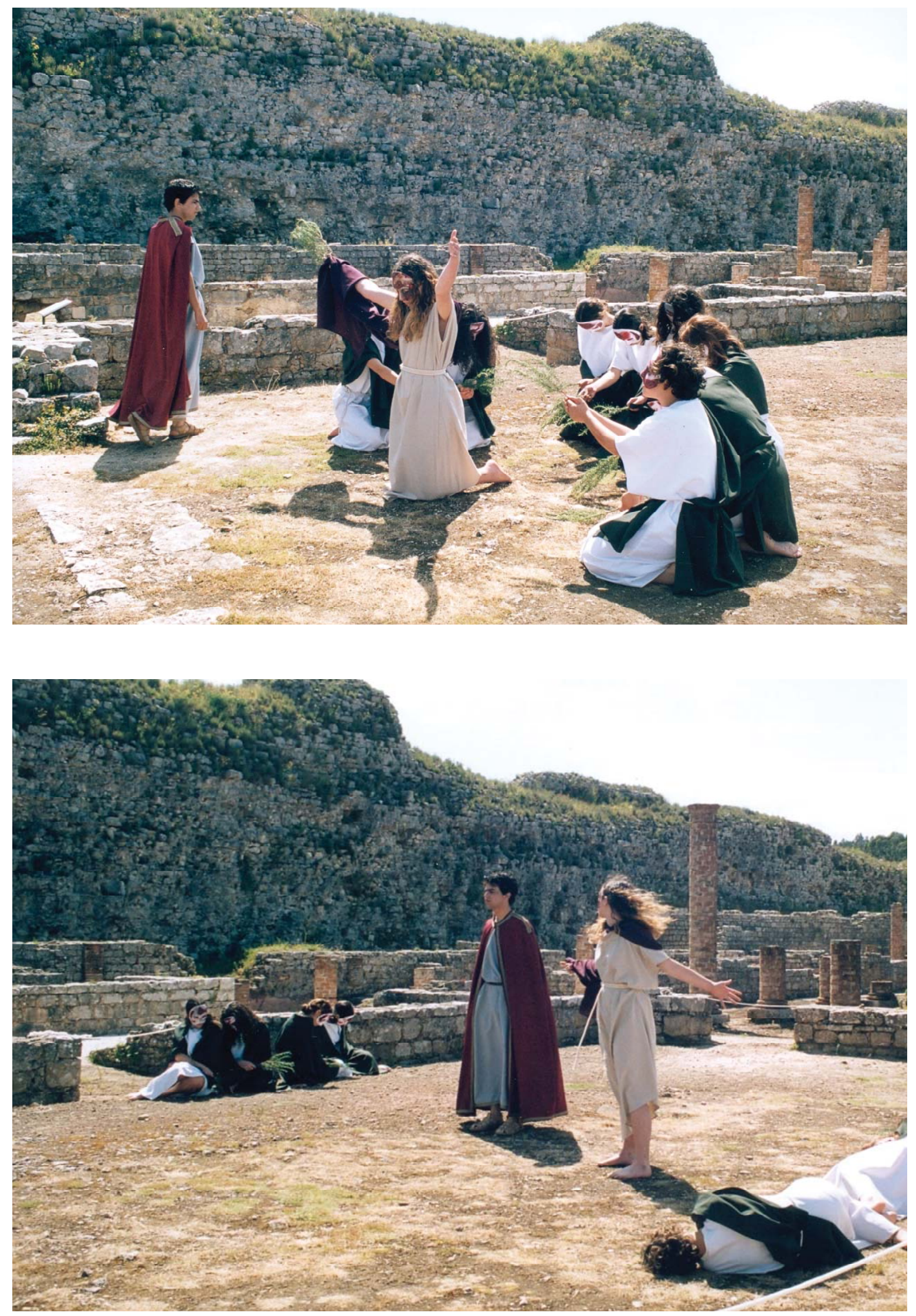

Rei Édipo de Sófocles Conimbriga

Fotos de José Batista 


\section{Antígona de Sófocles}

Grupo Balbo do IES de Puerto de Santa María (Cádis)

\section{Encenação e direcção}

Emilio Flor Jiménez

\section{Elenco}

Esther Punar Reyes (Antígona)

António Pantoja (Creonte)

Patricia López Ocana (Ismena)

Libertad Marin Rueda (Corifeu)

Juan Lorca (Guarda)

António Zarola (Hémon, Etéocles, Coro)

Francisco Rodríguez (Tirésias)

Jesús Maria Gutierrez Torres

(Polinices, Mensageiro, Coro)

Maria Serpa Mora, Antonio Zarola (Coro)

Miriam Perea (Eurídice)

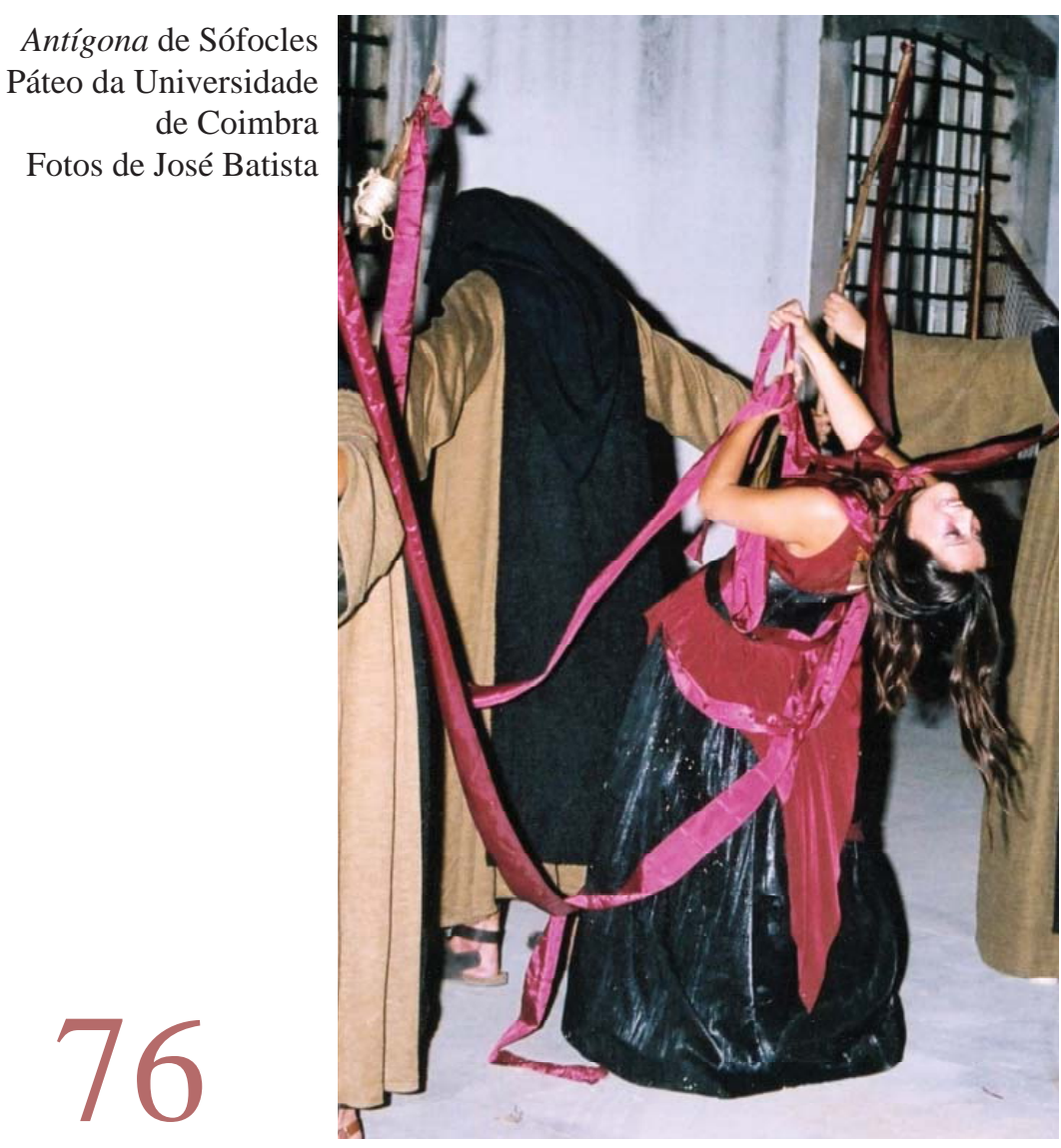

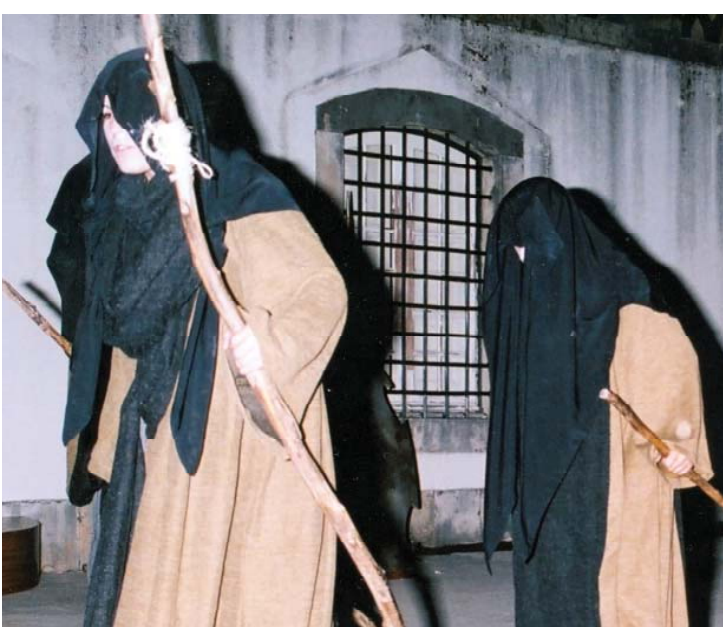

No ano das comemorações do $25 .^{\circ}$ centenário do nascimento de Sófocles, este grupo de Cádis trouxe a Coimbra, ao IV Festival de Teatro Escolar de Tema Clássico, a Antígona do tragediógrafo grego que, então, se homenageava.

Reproduzindo com grande fidelidade aspectos materiais do teatro grego, como o vestuário, os adereços e o cenário que adequadamente se caracterizavam pela simplicidade, o Grupo Balbo, dirigido por Emilio Flor, conseguiu transportar o espectador dos inícios do terceiro milénio para a Atenas do séc. V a.C., fazendo-o participar no conflito, sempre actual, entre a lei divina e a lei humana, o direito privado e o direito público, defendidos respectivamente pela intrépida Antígona e pelo inflexível Creonte.

Apesar de toda esta louvável fidelidade, o encenador assumidamente transgrediu, ao representar as mortes em cena, contrariando, assim, a tradição grega. Com esta prática do teatro romano, pretendia conferir à encenação o dramatismo que mais facilmente leva o espectador à catarse trágica. Este pormenor, discutível, não deslustra uma representação que se pautou por uma grande dignidade e rigor.

Carlos Morais, in Maria de Fátima Silva (coord.), Representações de Teatro Clássico no Portugal Contemporâneo III (Coimbra 2004) 35-36. 


\section{O Corpo de Helena de António José Miranda}

Grupo Ágon das Caldas da Rainha

\section{Adaptação e encenação}

Aníbal Rocha

Nesta coexistência temporal do clássico e do contemporâneo - onde os elementos cenográficos, os adereços e a banda sonora, para além da sua função como tal, assumem também importância simbólica e metafórica, quer na interacção das personagens, quer associados aos vários momentos trágicos - fundamentam-se a delimitação do espaço cénico e as marcações dos actores: sem descurar os grandes planos dos seus rostos (que eventualmente passarão despercebidos se os espectadores se situarem a determinada distância), investi em posições estáticas e abertas, como estátuas cuja postura é visível ao longe; para além de movimentações rígidas que delimitam psicologicamente um jogo de xadrez. Ao centro, presente/ausente, a Rainha (o corpo de Helena) domina, apesar de imóvel; todos os outros são atraídos por ela e ocupam o espaço em função daquele centro que ela ocupa. Menelau é o Rei-cavalo: movimenta-se em L sempre em função dela, não só para se sentir defendido, mas também para a proteger, ocupando uma casa à frente e atrás do leito. Ulisses e Agamémnon são Bispos e movimentam-se de acordo com a sua função. Ártemis tem um percurso diferente, em círculos apertados em torno de Menelau e do leito, como uma vontade superior que manipula a seu belo prazer os sentidos e as direcções das outras personagens.

Esses movimentos representam também que toda a dinâmica do conflito foi organizada pela sua vontade: simultaneamente despeito, orgulho ofendido ou, sendo Ártemis a deusa da caça, a fera que encurrala a presa e, recusando devorá-la, prefere divertir-se com o seu pathos. Porquê esta atitude implacável de Ártemis?
Não me parece que a razão tenha sido só porque Menelau "ousou desafiar os deuses".

Os quatro elementos femininos do Coro funcionam comabivalênciadeFúriase dasquatro Torres do jogo de xadrez; consequentemente, ocupam também o espaço cénico com posturas redondas e movimentos circulares. Mas representam também os quatro elementos que, ora individual ora colectivamente, ora em conflito ora em concordância, vão também sentindo o clímax da acção.

\section{Aníbal Rocha}

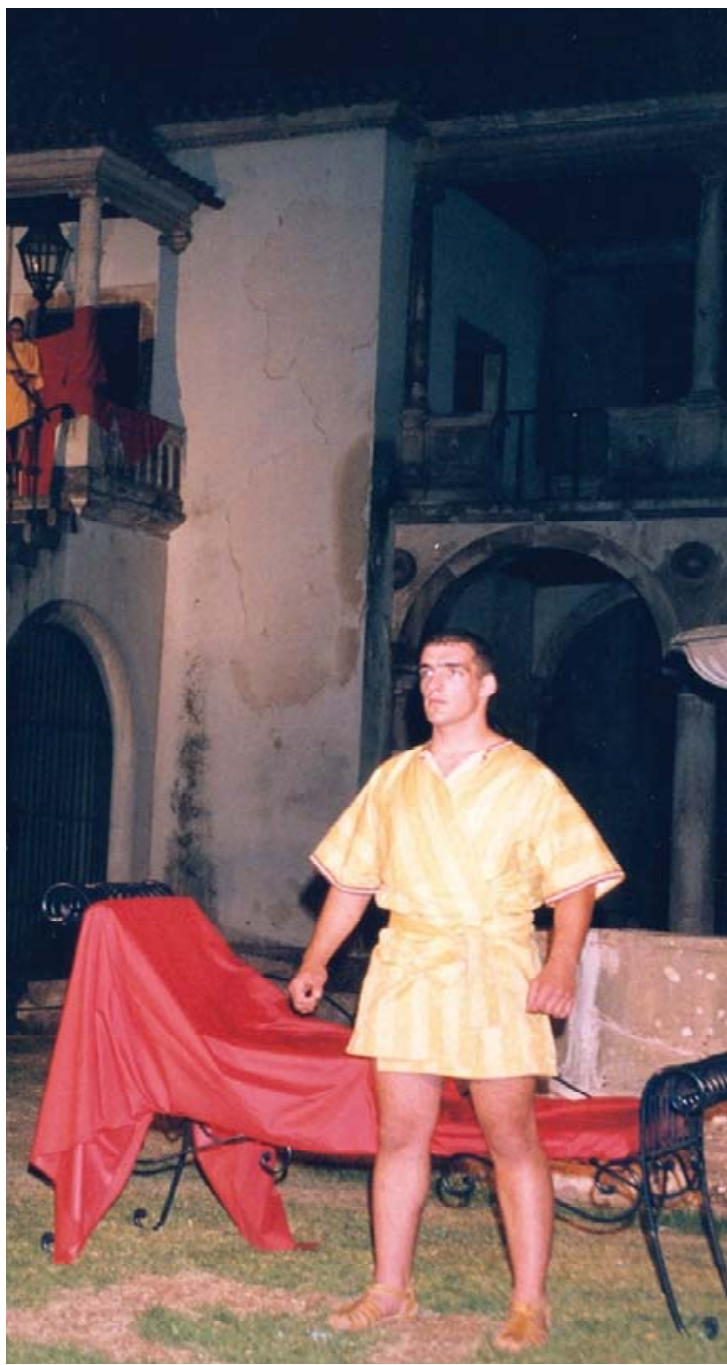

O Corpo de Helena Museu Nacional Machado de Castro Fotos de José Batista 
2 de Março de 2004, 16.00 horas, Centro Cultural D. Dinis (Coimbra) Marcial em trajes de cena, grupo Thíasos do IEC

11 de Março de 2004, 21.00 horas, Instituto Universitário Justiça e Paz (Coimbra) Marcial em trajes de cena, grupo Thíasos do IEC

3 de Abril de 2004, 21.00 horas, Tours (França) As Traquínias de Sófocles, grupo Thíasos do IEC

27 de Abril de 2004, 11.00 horas, Mosteiro de S. Martinho de Tibães (Braga) As Traquínias de Sófocles, grupo Thíasos do IEC

27 de Abril de 2004, 15.30 horas, Mosteiro de S. Martinho de Tibães (Braga) Anfitrião de Plauto, grupo Thíasos do IEC

28 de Abril de 2004, 15.30 horas, Antigo Convento de Santana (Coimbra) Anfitrião de Plauto, grupo Thíasos do IEC

29 de Abril de 2004, 21.30 horas, Auditório Mirita Casimiro (Viseu) As Traquínias de Sófocles, grupo Thíasos do IEC

29 de Abril de 2004, 15.30 horas, Conimbriga Os Dois Menecmos de Plauto, grupo Ágon das Caldas da Rainha

30 de Abril de 2004, 11.00 horas, Antigo Convento de Santana (Coimbra) Rei Édipo de Sófocles, grupo Teat®amus do Colégio de Calvão

3 de Maio de 2004, 11.00 horas, Museu Arqueológico de S. Miguel de Odrinhas (Sintra) As Traquínias de Sófocles, grupo Thíasos do IEC

3 de Maio de 2004, 16.00 horas, Museu Arqueológico de S. Miguel de Odrinhas (Sintra) Marcial em trajes de cena, grupo Thíasos do IEC

4 de Maio de 2004, 15.30 horas, Museu Arqueológico de S. Miguel de Odrinhas (Sintra) Os Dois Menecmos de Plauto, grupo Ágon das Caldas da Rainha

5 de Maio de 2004, 15.30 horas, Museu Arqueológico de S. Miguel de Odrinhas (Sintra) As Rãs de Aristófanes, grupo Batrakoi da Faculdade de Letras da Universidade de Lisboa

14 de Maio de 2004, 11.00 horas, Conimbriga Electra de Sófocles, grupo Arthistrión/Calatalifa de Madrid

14 de Maio de 2004, 15.30 horas, em Conimbriga O Soldado Fanfarrão de Plauto, grupo Arthistrión/Calatalifa de Madrid

15 de Maio de 2004, 21.30 horas, Teatro Viriato (Viseu) A Comédia da Cestinha de Plauto, grupo Arthistrión/Calatalifa de Madrid

18 de Maio de 2004, 21.30 horas, Conimbriga Mozart \& Mozart, grupo Canto e Drama do Conservatório de Música de Coimbra 


\section{FESTIVAL DE VERÃO}

\section{DE TEATRO DE TEMA CLÁSSICO}

10 de Junho de 2004, 19.00 horas, Conimbriga

Os Dois Menecmos de Plauto, grupo Ágon das Caldas da Rainha

25 de Junho de 2004, 21.30 horas, Louriçal

Marcial em trajes de cena, grupo Thíasos do IEC

26 de Junho de 2004, 21.45 horas, Teatro Académico Gil Vicente (Coimbra)

A Paz de Aristófanes, Companhia de Teatro de Almada

2 de Julho de 2004, 21.45 horas, Coimbra

Lisístrata de Aristófanes, grupo Meia Via de Torres Novas

3 de Julho de 2004, 18.45 horas, Conimbriga

Lisístrata de Aristófanes, grupo Meia Via de Torres Novas

5 de Julho de 2003, 21.45 horas, Museu D. Diogo de Sousa (Braga)

Anfitrião de Plauto, grupo Thíasos do IEC

6 de Julho de 2003, 21.45 horas, Museu D. Diogo de Sousa (Braga)

Antígona de Sófocles, grupo Balbo do IES de Puerto de Santa María (Cádis)

7 de Julho de 2004, 22.00 horas, Teatro Viriato (Viseu)

Antígona de Sófocles, grupo Balbo do IES de Puerto de Santa María (Cádis)

8 de Julho de 2004, 21.30 horas, Páteo da Universidade de Coimbra

As Coéforas de Ésquilo, grupo Balbo do IES de Puerto de Santa María (Cádis)

9 de Julho de 2004, 22.00 horas, Museu Grão Vasco (Viseu)

As Troianas de Eurípides, grupo Balbo do IES de Puerto de Santa María (Cádis)

10 de Julho de 2004, 21.45 horas, Museu D. Diogo de Sousa (Braga)

A Comédia do Fantasma de Plauto, grupo Balbo do IES de Puerto de Santa María (Cádis)

11 de Julho de 2004, 21.45 horas, Museu D. Diogo de Sousa (Braga)

As Traquínias de Sófocles, grupo Thíasos do IEC

14 de Julho de 2004, 21.45 horas, Átrio do Pátio da Inquisição (Coimbra)

Os Dois Menecmos de Plauto, grupo Ágon das Caldas da Rainha

15 de Julho de 2004, 21.45 horas, Claustros da Sé Velha (Coimbra)

Electra de Sófocles, produção Festea / Thíasos do IEC

16 de Julho de 2004, 16.30 horas, Conimbriga

Electra de Sófocles, produção FESTEA / Thíasos do IEC

17 de Julho de 2004, 22.00 horas, Centro de Artes e Espectáculos da Figueira da Foz Anfitrião de Plauto, grupo Thíasos do IEC

18 de Julho de 2004, 19.00 horas, Conimbriga

A Rapariga de Samos de Menandro, Theatro do Lyceu da Figueira da Foz

22 de Julho de 2004, Puerto de Santa María (Cádis)

As Traquínias de Sófocles, grupo Thíasos do IEC 


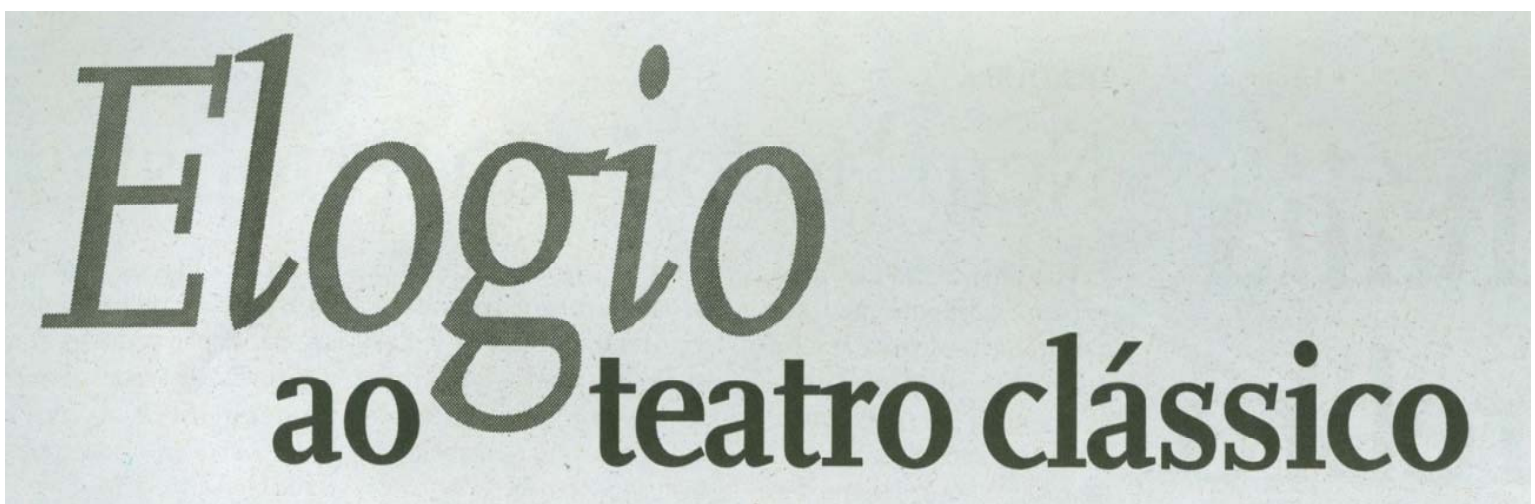

O teatro de tema clássico irá aproximar cinco cidades portuguesas. Até I8 de Julho vai decorrer o VI Festival Internacional de Verão de Teatro Clássico.

eis grupos de Portugale Espanha participam no VI FESTEA-Festival Internacional de Verão de Teatro Clássi$\mathrm{co}$, que se inicia na quinta-feira e se prolonga até I 8 de Julho em cinco cidades, foi ontem anunciado em conferência de Imprensa.

Coimbra e a antiga cidade romana de Conímbriga, com cinco espectáculos cada, são as localidades mais visitadas pelo festival, mas também Braga (duas representações), Viseu e Figueira da Foz (uma cada) constituem itinerários dos grupos.

No seu conjunto vão apresentar-se i4 espectáculos, sendo que o programa abre dia ro no palco natural das ruínas romanas de Conímbriga com a apresentação de "Os dois Menecmos", de Plauto, pelo Grupo Agon, das Caldas

Diário As Beiras da Rainha.

O segundo espectáculo, “A Paz", de Aristófanes, está agen-

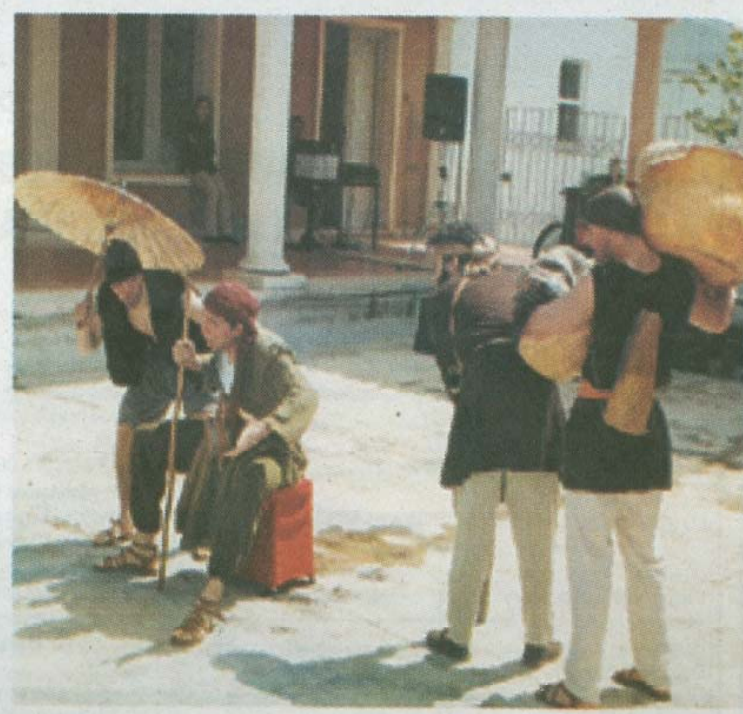

dado para o próximo dia 23 no Teatro Académico de Gill Vicente (TAGV), em Coimbra, e será apresentado pela única companhia profissional a participar no FESTEA, o Grupo de Teatro de Almada.

De Puerto de Santa Maria de Cádis, Espanha, irá chegar o grupo Balbo, que trará ao FESTEA quatro produções distintas, "Antígona" (Sófocles), "As Troianas" (Eurípides), "As Coéforas” (Ésquilo) e "A Comédia do Fantasma" (Plauto).

Balboé o nome de uma célebre família romana que teve uma importância decisiva nas reformas romanizadoras da antiga cidade de Gades, a que o grupo prestou homenagem ao escolher o seu nome.

Este grupo amador, criado pe lo professor de Latim Emilio Flor, desde I974 que encena peças clássicas com um objectivo didáctico e pedagógico.

O Grupo Thíasos, do Instituto de Estudos Clássicos da Faculdade de Letras da Universidade de Coimbra, irá apresentar no festival três produções, "As Traquínias", "Electra" (ambas de Sófocles) e "Anfitrião" (Plauto).
OThíasos surgiu oficialmente em 2000 , mas o seu nascimento remonta a I99I, quando um grupo de assistentes daquele instituto da Faculdade de Letras decidiu montar um espectáculo para apresentar na cerimónia comemorativa da sagração da Sé Velha de Coimbra.

"A Listrata", de Aristófanes, levada à cena pelo Teatro Meia Via, de Torres Novas, um grupo fundado em 200I, e "A Mulher de Samos", de Menandro, pelo Theatro do Lyceu, da Escola Joaquim de Carvalho da Figueira da Foz são as restantes produçõ̀es programadas.

As ruínas romanas de Conímbriga; o Teatro Viriato, de Viseu; 0 Centro de Artes do Espectáculo da Figueira da Foz; o Museu D. Diogo de Sousa, de Braga; o jardim da Sereia; o Pátio da Universidade e os Claustros da Sé Velha (todos em Coimbra) são alguns dos palcos naturais escolhidos para as representações.

O VI FETEA - Festival Internacional de Verão de Teatro Clássico é organizado pela associação com o mesmo nome em conjunto com o Grupo Thíasos da Faculdade de Letras de Coimbra e a Liga dos Amigos de Conímbriga. 


\section{Marcial em Trajes de Cena}

Grupo Thíasos do IEC

\section{Tradução}

Delfim Ferreira Leão, José Luís Brandão, Paulo Sérgio Ferreira

Dramaturgia e encenação

Carlos Jesus e Carla Braz

Selecção de textos

José Luís Brandão

Coreografia

Carla Braz

Consultores

Delfim Leão, José Luís Brandão

Sonoplastia

Carlos Jesus, Tiago Cabral

Luminotecnia

Carlos Santos

Guarda-roupa

Carla Braz

Inês Santos

Adereços

Carlos Santos, Inês Santos Elenco

Carlos Jesus, Carla Braz, Mariana Matias, Verónica Fachada, Patrícia Martinho,

Sónia Simões, Natália Alves, Isabel Santos,

Bruno Simões, Eduardo Conceição,

Ana Catarina Rodrigues, Ândrea Oliveira, Joana Cruz, Lia Nunes

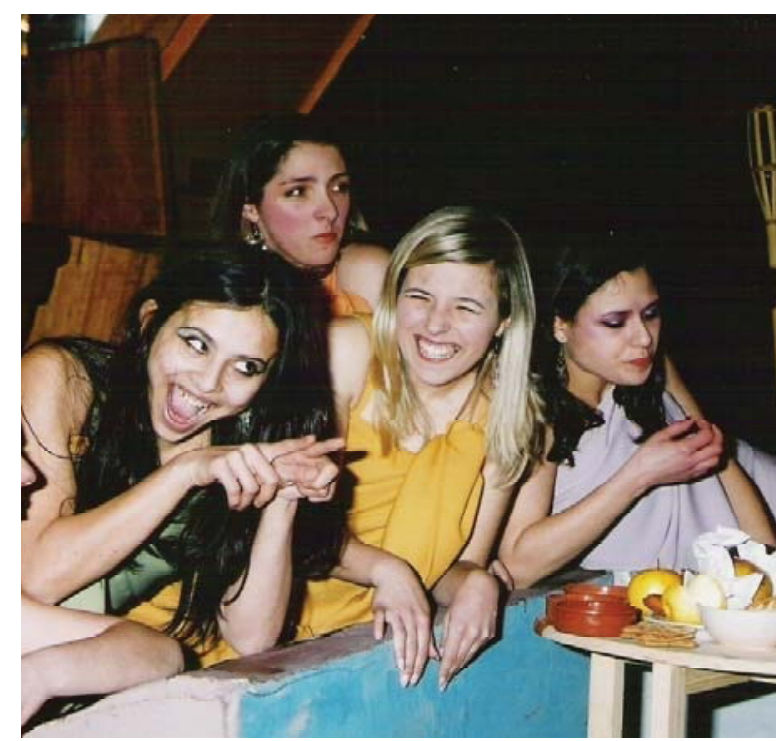

Estreada a 2 de Março de 2004, no encerramento das jornadas científicas "Celebração de Marcial 2004”, a peça consiste na recolha e dramatização de vários epigramas do poeta latino, comemorando os 1900 anos passados sobre a sua morte. De uma primeira e animada cena de banquete, onde se representam os quadros sociais mais característicos da escrita do autor - os ébrios, os caçadores de heranças, os advogados ou os efeminados - as personagens, todas elas anónimas, simulam alegoricamente o regresso de Marcial à sua terra Bílbilis, na Hispânia. Aqui contempla ele a simplicidade da vida, tecendo invectivas ao ritmo citadino com todos os seus vícios. Nasce a saudade da agitação cosmopolita, terminando a peça com o desencanto e a morte (sugerida) da figura central.

Tudo se passa num plano simbólico. O resultado que se apresenta mais não é do que um exercício de interpretação, entre outros possíveis, da vida e obra de um artista, mas em especial de um homem que marcou o seu tempo e a posteridade.

Carlos A. Martins de Jesus, in Maria de Fátima Silva (coord.), Representações de Teatro Clássico no Portugal Contemporâneo III (Coimbra 2004) 178.

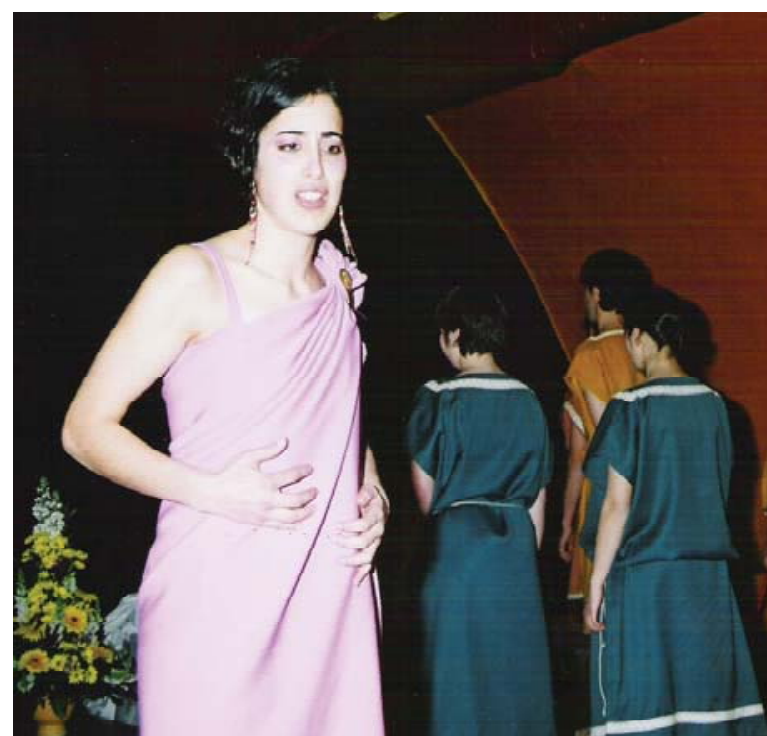




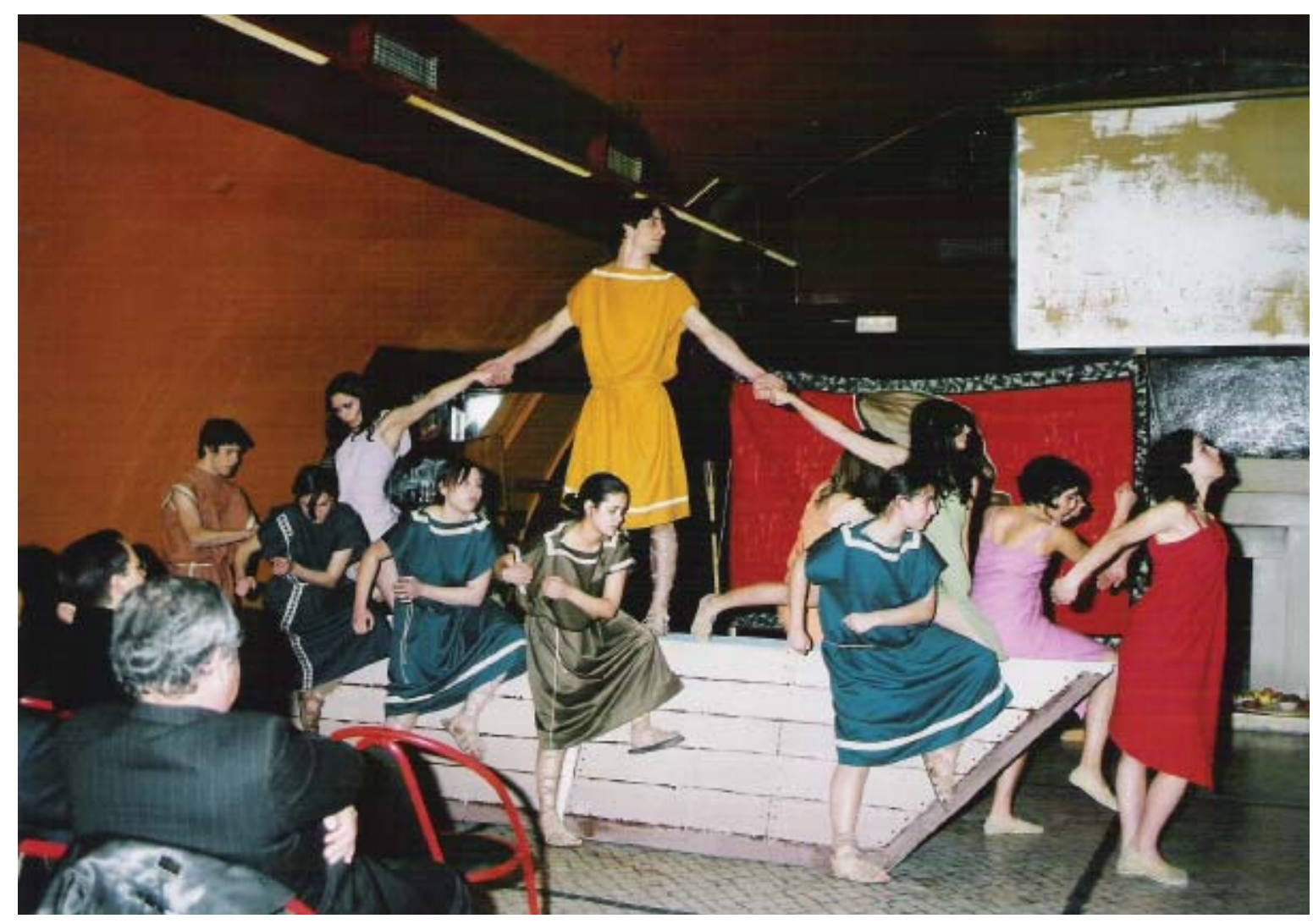

Marcial em Trajes

Centro Cultural

D. Dinis

Fotos de José Batista

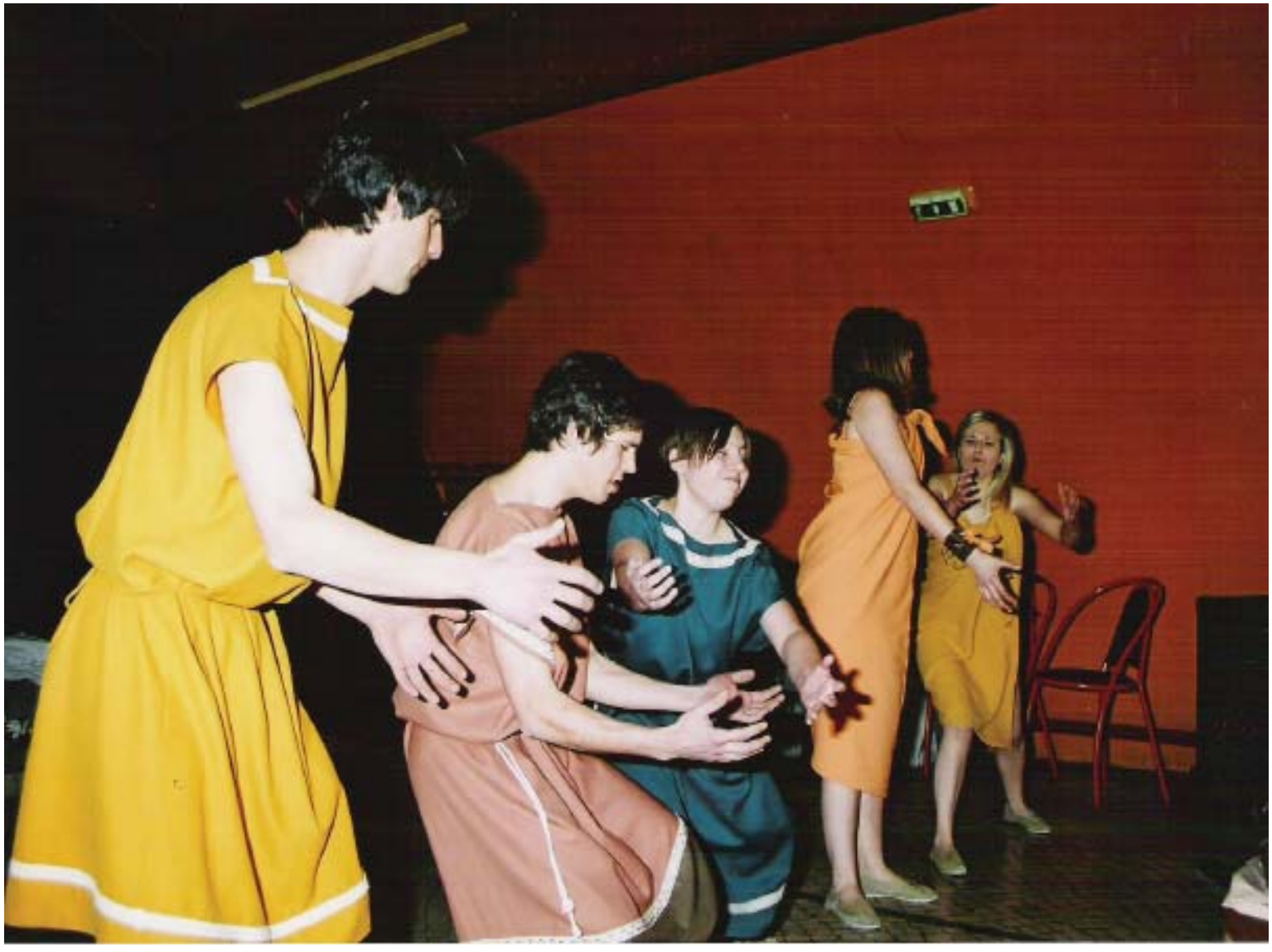




\section{Os dois Menecmos}

a partir de Plauto Grupo Ágon das Caldas da Rainha

\section{Adaptação e encenação}

Aníbal Rocha

\section{Cartaz e cenografia}

Humberto Sobreira

Costureira

Maria Celeste Magalhães

Técnicos

António Anunciação e João Santos

\section{Elenco}

Aníbal Rocha (Prólogo e Escova)

Frederico Sobreira (Menecmo I)

Liliana Abreu (Erócio)

Hélder Gomes (Messenião)

Humberto Sobreira (Menecmo II)

Cristina Canotilho (Criada)

Ana Maria Ribeiro (Mulher de Menecmo I)

Pedro Brás (Velho)

António Ramalho (Médico)

Linda Grosso, João Santos,

Sérgio Marcelino (Figurantes) 


\section{As Rãs de Aristófanes}

Grupo Batrakoi da Faculdade de Letras

da Universidade de Lisboa

\section{Tradução}

Américo da Costa Ramalho

(com adaptações pontuais do grupo)

Direcção de actores e encenação

José Pedro Moreira

Ana Cristina Matafome

Guarda-roupa e maquilhagem

Batrakoi

Elenco

Catarina Gaspar (apresentação)

Ana Cristina Matafome (Corifeu)

Susana (Maestrina)

Helena Sabina, Catarina Carvalheiro

("Coaxadoras")

André Simões (Dioniso)

José Pedro Moreira (Xântias)

Luís André Agostinho (Morto, Caronte)

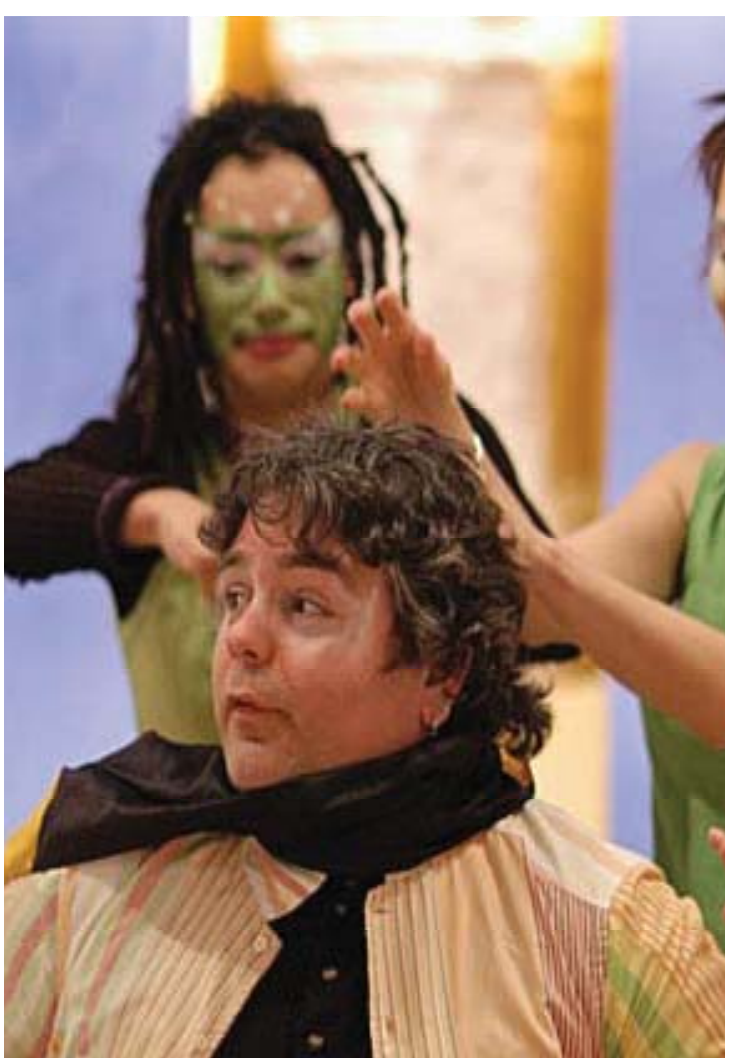

As Rãs de Aristófanes

Museu Arqueológico de S. Miguel de Odrinhas

Fotos do grupo
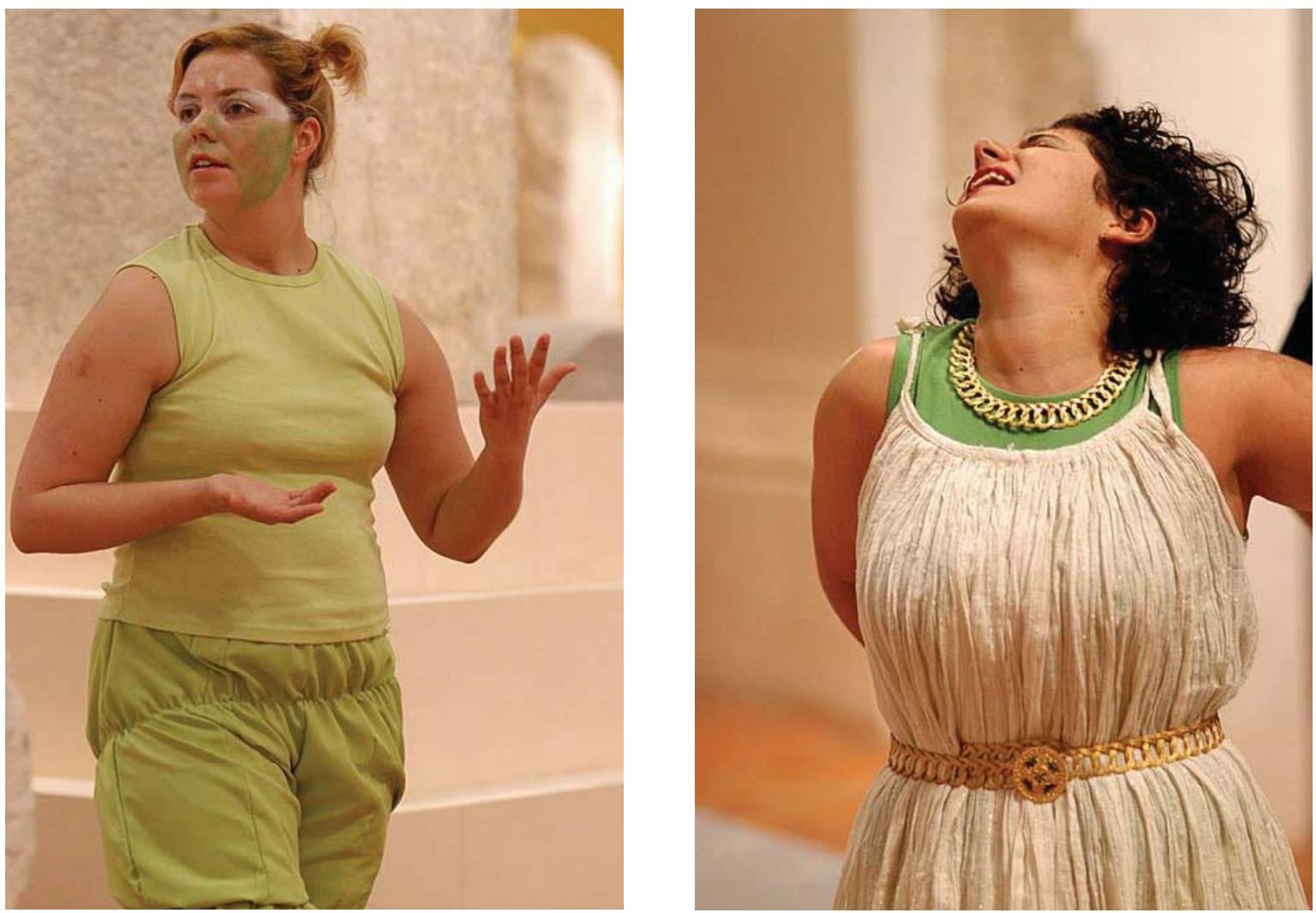


\section{A Comédia da Cestinha de Plauto}

Grupo Arthistrión/Calatalifa de Madrid

Versão e tradução

Pedro Sáenz Almeida

Direcção

Susana Verdú Martínez

Pedro Sáenz Almeida

Tradução e reconstrução cénica

Pedro Sáenz Almeida

Vestuário

Ruth P. Sánchez

Coreografia

Susana Verdú

Cenografia

Roberto López

Música

Juan G. Poveda

Iluminação e som

Sonia García

Coordenação

Luis Jiménez, Susana Verdú

\section{Elenco}

Alba Rodríguez (Selénia)

Susana Verdú (Gimnásia)

Raul Verdú (Sira)

Carlos Martos (Deus Auxílio)

Luis Jiménez (Alcesimarco)

Javier Oleza (Pai)

Juanjo Sánchez (Lampadião)

Lucía Díaz (Melénide)

Paola Martínez (Fanóstrata)

Débora Mamblona (Halisca)
A jovem Selénia, que tinha sido abandonada à nascença e recolhida por uma meretriz, enamora-se de um jovem de boas famílias, Alcesimarco, que também a deseja loucamente. Mas este belo idílio vê-se interrompido pelo pai do jovem, empenhado em casar o filho com uma rapariga da sua classe social.

O idealismo dos jovens confronta-se assim com o realismo dos adultos; amor e conveniência são os parâmetros que marcam o motivo desta comédia: os meandros da trama argumentativa irão tecendo os fios que desembocarão no reconhecimento da menina abandonada por seus pais verdadeiros e que nos levarão directamente ao triunfo do amor.

Esta comédia de Plauto, estreada à volta do ano 203 a.C., é um excelente exemplo de que a fabula palliata latina deve aos autores da Comédia Nova grega.

O lamentável estado de conservação dos manuscritos latinos, que nos transmitiram a Cistellaria - faltam-lhe mais de 600 versos tornou necessária uma reconstrução para que também esta obra de Pauto pudesse subir aos palcos.

do Programa

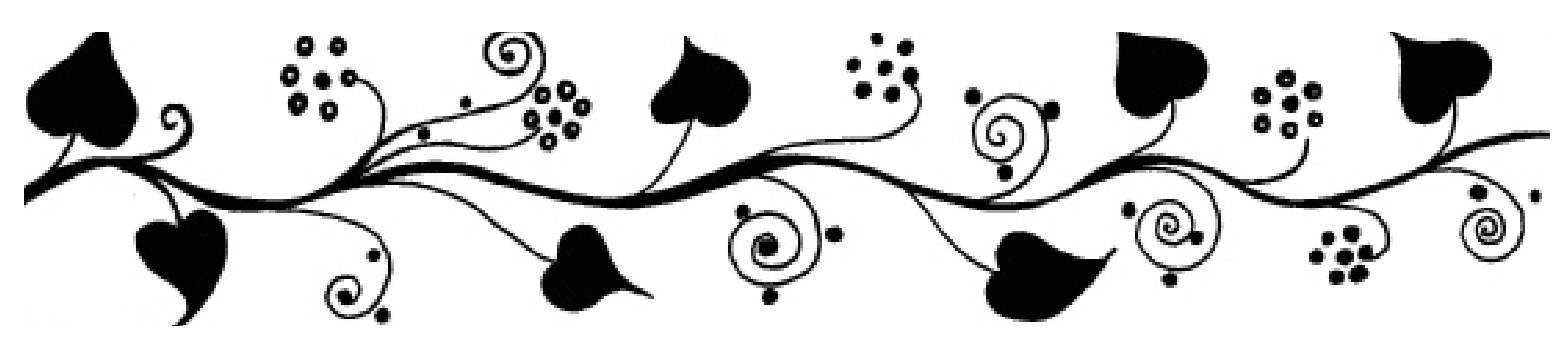




\section{A Paz de Aristófanes}

Companhia de Teatro de Almada

\author{
Tradução \\ Maria de Fátima Silva \\ Encenação \\ Vítor Gonçalves \\ Cenário e figurinos \\ Maria João Vieira Ramos \\ Coreografia \\ Raquel Vieira de Almeida \\ Apontamento musical \\ André Louro \\ Desenho de luz \\ José Carlos Nascimento \\ Elenco \\ Alfredo Sobreira (Guerra, Escravo, Coro) \\ André Louro (Hermes, 2. ${ }^{\circ}$ Escravo) \\ Cátia Ribeiro (Filha, Coro) \\ Francisco Costa (Trigeu) \\ Luís Ramos (Hiérocles, Escravo, Coro) \\ Maria Frade (Refrega, Coro) \\ Miguel Martins (Vendedor de armas, Coro) \\ Filipa Moraes (Folgança) \\ Susana Mendes (Deusa dos frutos)
}

A Companhia de Teatro de Almada levou à cena $\mathrm{A} \mathrm{Paz}$ de Aristófanes. O contexto internacional era propício a que se falasse de paz, quando o ataque aliado contra o Iraque se processava, perante uma larga contestação proveniente de diversos países. Correndo todos os riscos de confrontar um público moderno com a peça de 421 a.C., encomendada para celebrar, em Atenas, a paz de Nícias que então suspendia, por tempo escasso, o conflito com as forças do Peloponeso, passando por cima das características menos fulgurantes desta produção de Aristófanes, a Companhia de Teatro de Almada brindou os muitos espectadores que aderiram ao espectáculo com uma produção a todos os títulos meritória.

Decerto que a impressão geral mais imediata tem a ver com a vivacidade que se manteve uma constante em toda a representação. O texto, desprovido de muitos dos recursos que fizeram a riqueza cómica de outras produções do poeta de Atenas, e enriquecido com outro tipo de elementos marcados por uma nostalgia sofrida perante a saudosa paz, tende a ser de alguma forma pálido de efeitos, e só a gesticulação apropriada e a boa exploração dos tons subjacentes ao texto permitiram torná-lo divertido e mobilizador.

A encenação foi também feliz. Valorizando o contrastebranco/preto(paz/guerra), solucionou com recursos apropriados os aspectos especiais de cena que a peça coloca: o voo de Trigeu ao Olimpo sobre um escaravelho voador suspendeu Francisco Costa sobre um gracioso animal alado, que o fez elevar-se sobre a cena; o almofariz da guerra e o pilão exprimiram-se como uma simulação rolante que pôs em cena um efeito adequado; uma simples sanita isolada em cena, no início do espectáculo, marcou o tom do banquete servido ao escaravelho.

O texto foi integralmente respeitado, com todas as dificuldades que pode colocar a um público cronologicamente desfasado do contexto primitivo e muito do seu sucesso dependeu da forma como foi dito, sem permitir que momentos difíceis como a parábase deixassem cair o efeito. Para resolver o problema da sua pouca extensão, a peça foi acrescentada pela colagem do monólogo de Diceópolis, na abertura de Acarnenses, numa contaminatio que permitiu, de resto, fundamentar com os queixumes de um ateniense desgostoso com o rumo dos acontecimentos na sua cidade o voo utópico de Trigeu em busca de uma resposta dos deuses. Uma palavra de elogio é devida ao trabalho de actores e à solução do coro, que foi mobilizando os diversos actores, e que deu voz às preocupações colectivas sem privar cada um dos seus elementos de alguma individualidade; um compromisso, portanto, bem sucedido entre o individual e o cívico.

Maria de Fátima Silva, in Representações de Teatro Clássico no Portugal Contemporâneo III

(Coimbra 2004) 82-84. 

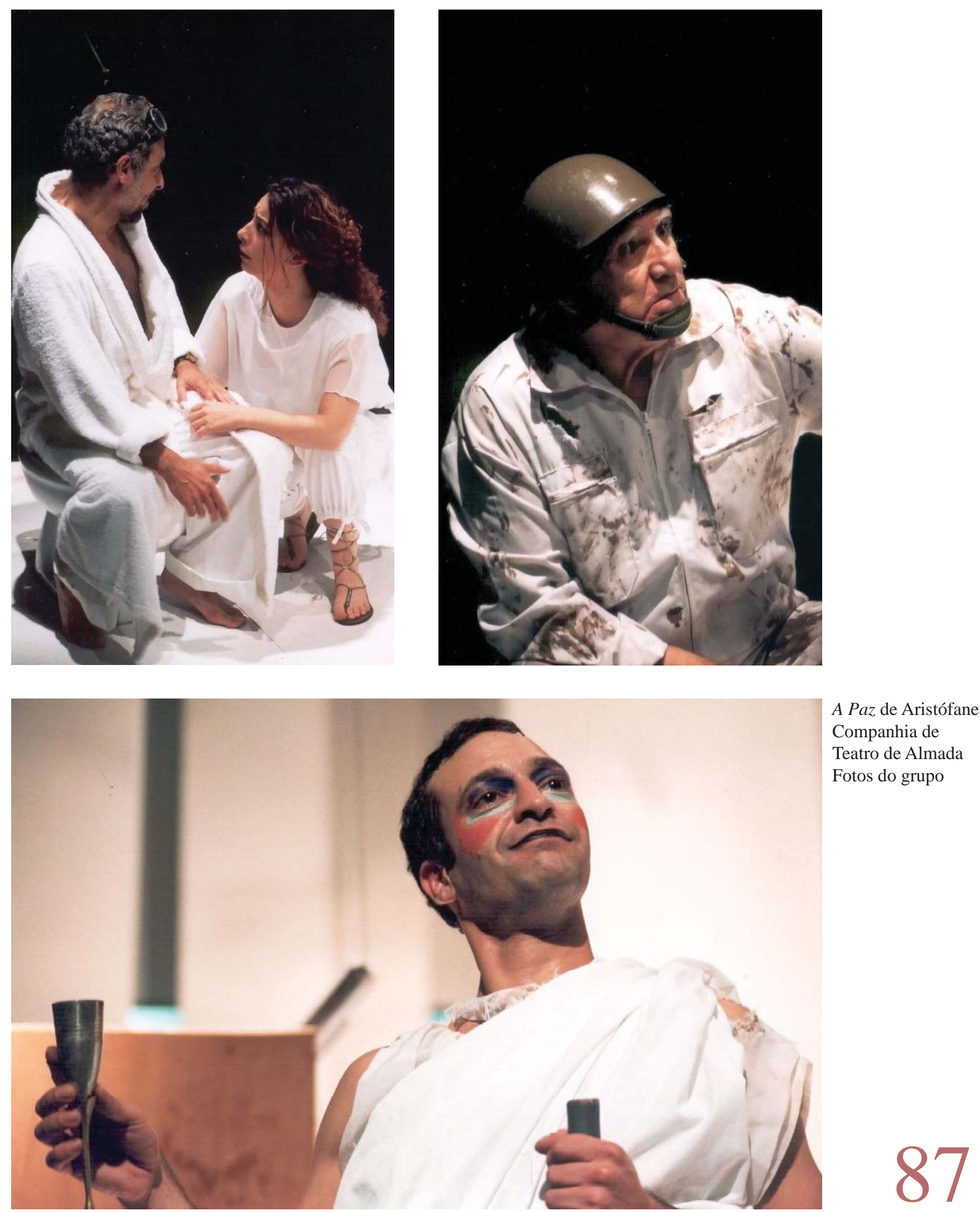


\section{Soldado Fanfarrão de Plauto}

Grupo Arthistrión/Calatalifa de Madrid

\section{Versão e tradução \\ Pedro Sáenz Almeida \\ Direcção \\ Susana Verdú Martínez \\ Pedro Sáenz Almeida \\ Vestuário \\ Ruth P. Sánchez \\ Coreografia \\ Susana Verdú \\ Iluminação e som \\ Sonia García \\ Coordenação}

Luis Jiménez, Susana Verdú

\section{Elenco}

Raúl Verdú (Pirgopolinices)

Pablo Martínez (Artotrogo)

Luis Jiménez (Palestrião)

Javier de Oleza (Periplectómeno)

Juanjo Sánchez (Esceledro)

Alba Rodríguez (Filocomásia)

Susana Millán (Criada)

Carlos Martos (Plêusicles)

Débora Mamblona (Milfidipa)

Lucía Díaz (Acrotelêucia)

Pablo Martínez (Caríon)
A meretriz Filocomásia, na ausência de Plêusicles, é levada contra a sua vontade de Atenas para Éfeso pelo miles Pirgopolinices e forçada a viver como sua concubina. Avisado pelo escravo Palestrião, que está agora ao serviço de Pirgopolinices, Plêusicles chega a Éfeso e instala-se em casa de Periplectómeno, velho amigo de seu pai, que vive justamente numa casa contígua à do miles. A partir daí, põem-se em jogo os enredos e artimanhas do astuto Palestrião para libertar Filocomásia do poder de Pirgopolinices, enganando o miles.

do Programa

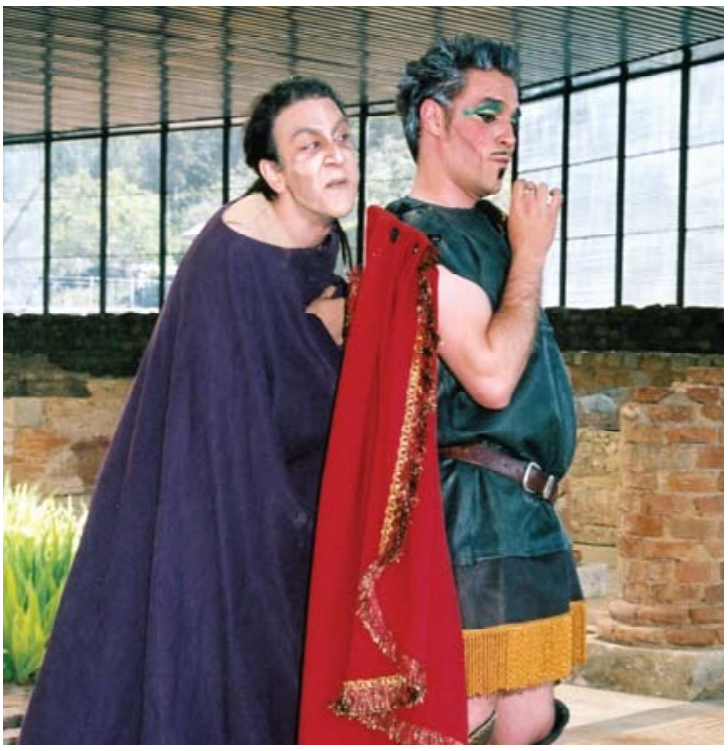

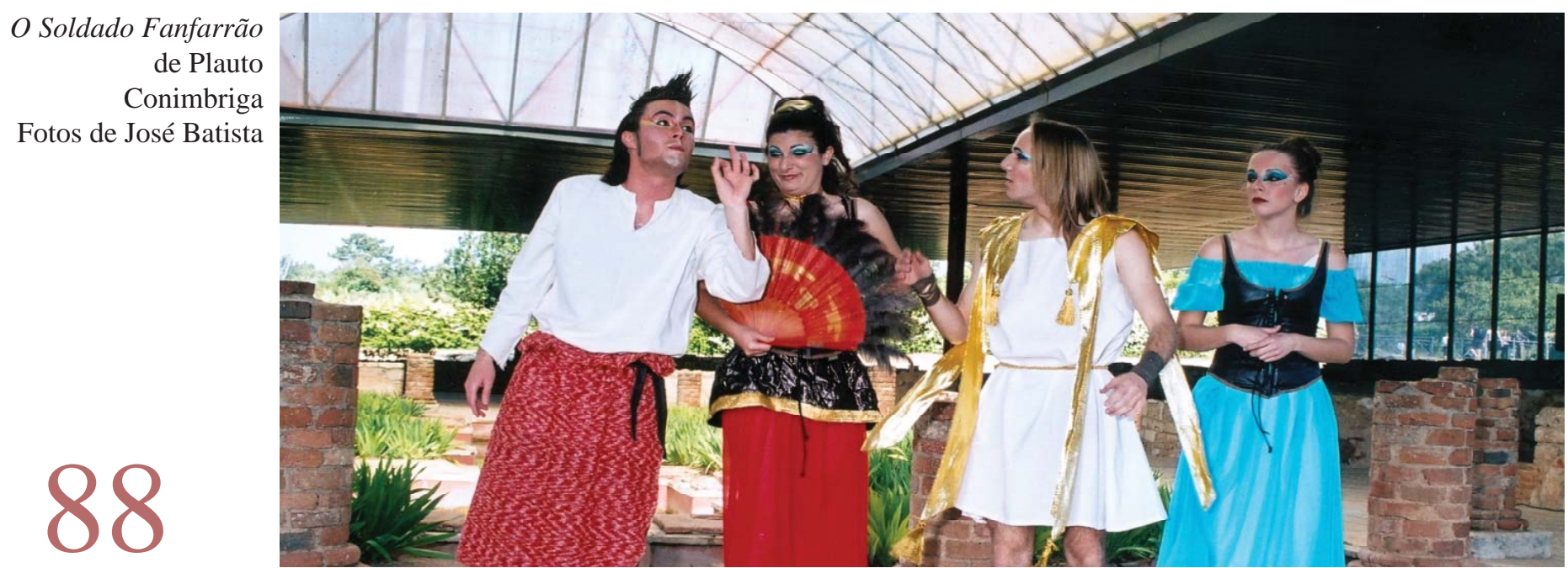




\section{A Rapariga de Samos de Menandro}

Theatro do Lyceu da Figueira da Foz

\section{Tradução}

Maria de Fátima Silva

Adaptação e encenação

António Tavares

Adereços e guarda-roupa

Ana Paula Índio

Confecção do guarda-roupa Justina Martelo

Adereços cenográficos

Hermínio Monteiro

\section{Anotação e apoio de cena}

Fernanda Sobral

Elenco

Carlos Santos, Helena Sales, Isabel Cardoso,

Jaime Beja, João Paulo Borronha,

Lígia Bugalho, Margarida Bessone, Nelson

Cadete, Rita Miranda, Sara Tavares

Trata-se, como sempre em Menandro, de uma história doméstica que tem por móbil um romance de amor à procura do momento de se concretizar em casamento e felicidade. Neste caso, o que é também vulgar, mais do que um simples sentimento, a história parte de uma paixão que teve, numa festa nocturna, o desafogo urgente da violação de uma moça, de onde resultou o nascimento de uma criança; tudo ainda na ignorância dos pais de família. Ao longo de uma intriga, organizada em cinco actos, vai-se viver um jogo de avanços e recuos com vista a um desfecho que, todos de antemão o sabemos, será um inevitável happy-end. São sobretudo os desacertos entre pai e filho o entrave ao curso fácil dos acontecimentos.

Maria de Fátima Silva (da Introdução à tradução)

\section{Electra de Sófocles}

Produção Festea / Thíasos

\author{
Tradução \\ Maria do Céu Fialho \\ Adaptação e encenação \\ Cristina do Aido \\ Música \\ Tiago Cabral \\ Elenco \\ Joaquim Silva, Lia Nunes, Natália Alves, \\ Verónica Fachada \\ Máscaras e figurinos \\ Cristina do Aido, Manuel João Vieira \\ Desenho de luz \\ Cristina do Aido
}

Electra, como leoa ferida, encarna as mais obscuras, violentas e elementares forças da natureza. Por seu lado, o irmão Orestes representa o modelo do herói apolíneo, forte e despreocupado, belo e cheio de luz, mesmo quando, cumprindo o oráculo de Apolo, mata a mãe para vingar o assassinato de seu pai.

Emvoltados doisirmãos movem-seas demais personagens, magistralmente caracterizadas, combinadas e dispostas por Sófocles dentro de uma acção dramática que, concebida como uma caçada, avança directamente para a armadilha final em que os assassinos pagarão o seu crime. Com a morte de Clitemnestra e do seu amante Egisto, resolve-se o conflito que abre e põe em marcha a tragédia: o crime tem de pagar-se com o crime. A vingativa Némesis do morto fica assim aplacada. 


\section{TEATRO}

\section{Thíasos leva "Electra" aos claustros da Sé Velha}

\section{- E COM O GRUPO de teatro}

do Instituto de Estudos Clássi$\cos$ da Faculdade de Letras da Universidade de Coimbra que prossegue esta noite, às $2 \mathrm{IH}_{45}$, nos claustros da Sé Velha de Coimbra, o VI Festival Internacional de Verão de Teatro de Tema Clássico. O Thíasos levará à cena "Electra", uma das mais cé-

Diário As Beiras (15 de Julho de 2004) lebres e apresentadas peças de Sófocles. Amanhã, quando forem $\mathrm{I} 8 \mathrm{H}_{3} \mathrm{O}$, o grupo levará "Electra" ao espaço das ruínas romanas de Conímbriga.

"Electra" é a versão sofocliana da vingança dos filhos de Agamemnon, Orestes e Electra, pelo assassinato de seu pai. Orestes, afastado de Argos durante anos, retorna para vingar a morte de Agamemnon. Depois de encontrar a irmã, Electra, consegue entrar no palácio e matar Egisto e Clitemnestra.

Foi em Novembro de I99I que alguns dos assistentes que agora integram o corpo de docentes do Instituto de Estudos Clássicos-então colegas de curso - encenaram, na cerimónia comemorativa da sagração da Sé Velha de Coimbra, um texto original, da autoria de Delfim Leão, intitulado Sé Velha - Pedras Vi- vas. Essa primeira iniciativa, inteiramente preparada por alunos, iria conhecer um importante avanço em Março de I992, altura em que discentes do $4 .^{\circ}$ ano de licenciatura organizaram um colóquio subordinado ao tema "O Amor desde a Antiguidade Clássica". Entre as várias actividades propostas, foi possível assistir à representação de parte do "Soldado Fanfarrão" plautino, levado à cena pelo autor da versão portuguesa da comédia, C. A. Louro Fonseca. Foi a partir desse momento que se colocou, verdadeiramente, a possibilidade de criar um grupo de teatro de tema clássico.

Em todo o caso, somente em I996 é que se retomou o projecto de teatro, com a rodagem, em Conímbriga, da versão vídeo da comédia de Aristófanes "Mulheres no Parlamento", sob a direcção de Delfim Leão. A iniciativa visava atingir dois objectivos: por um lado, dar vida aquele que é considerado o maior autor da Comédia Antiga; por outro, aproveitar um espaço arqueológico privilegiado, como é o caso de Conímbriga. E assim nasceu o Thíasos, que entretanto se transformou em associação cultural. 
A 22 de Julho de 2004 o grupo Thíasos do IEC teve a oportunidade de apresentar As Traquínias em Puerto de Santa María (Cádis), a convite do grupo Balbo dessa cidade, um dos grupos com presença mais habitual no Festival de Teatro de Tema Clássico.

O recorte de jornal que a seguir reproduzimos, em ano de Campeontado Europeu de Futebol, que terminou com a fatídica derrota da selecção nacional pela da Grécia, exprime o bom humor com que o grupo foi acolhido em terras de Espanha.

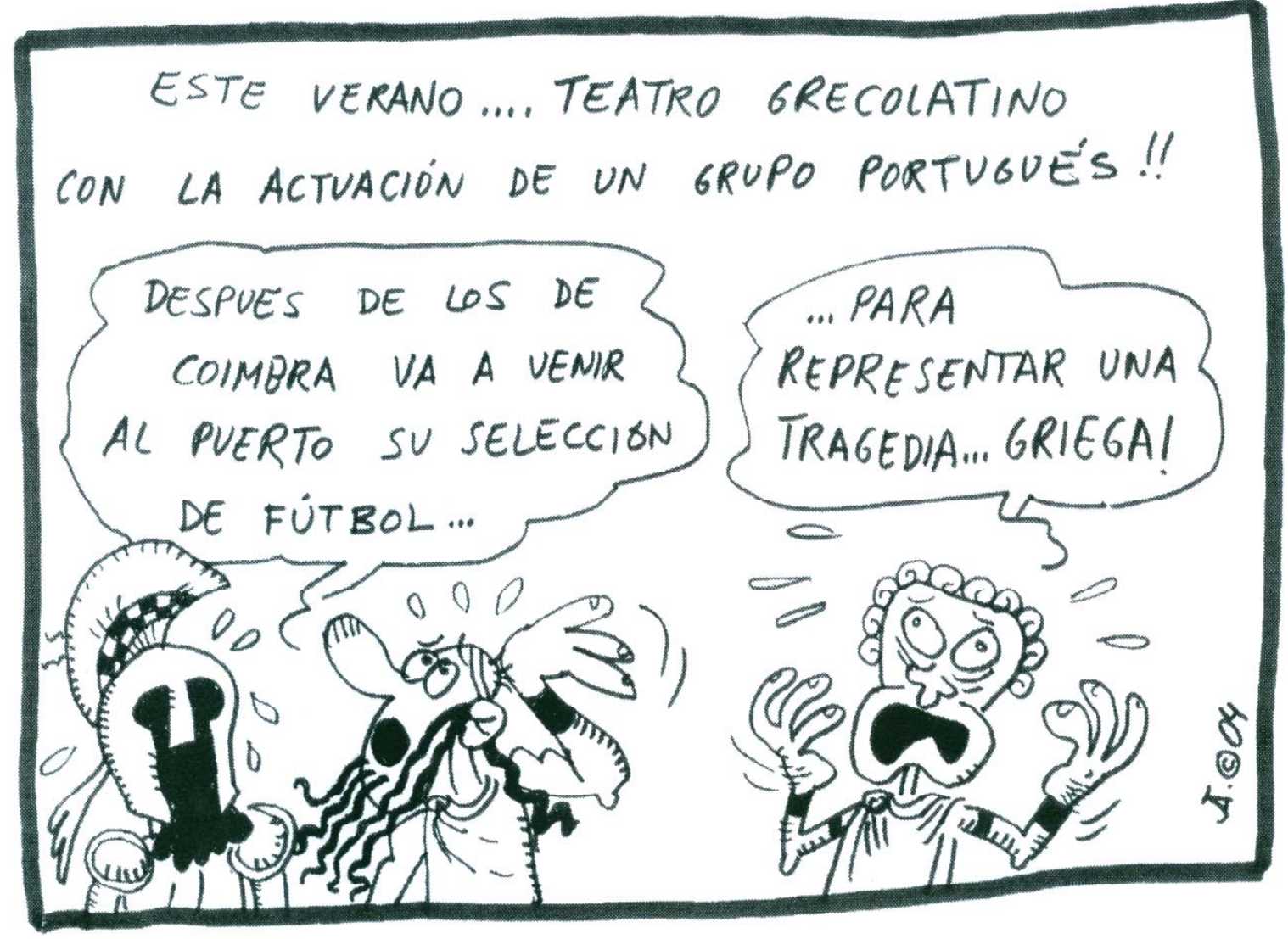

El Puerto (24 de Julho de 2004) 
20 de Abril de 2005, 11.00 horas, Conimbriga As Mulheres no Parlamento de Aristófanes, grupo Thíasos do IEC

26 de Abril de 2005, 11.00 horas, S. Martinho de Tibães (Braga) Electra de Sófocles, produção Festea / Thíasos do IEC

26 de Abril de 2005, 15.30 horas, S. Martinho de Tibães (Braga) Os Dois Menecmos de Plauto, grupo Ágon das Caldas da Rainha

27 de Abril de 2005, 11.00 horas,Conimbriga Electra de Sófocles, produção Festea / Thíasos do IEC

28 de Abril de 2005, 15.30 horas, Convento S. Francisco (Coimbra) Ulisses de Maria Alberta Menéres, grupo Angelus do Colégio de S. Miguel (Fátima)

30 de Abril de 2005, 21.30 horas, Teatro Viriato (Viseu) Teócrito e Virgílio, grupo Thíasos do IEC

2 de Maio de 2005, 11.00 horas, Convento de S. Francisco (Coimbra) Helena de Eurípides, grupo Selene do IES Carlos III de Madrid

2 de Maio de 2005, 15.30 horas, Convento de S. Francisco (Coimbra) Pluto (A Riqueza) de Aristófanes, Selene do IES Carlos III de Madrid

2 de Maio de 2005, 11.00 horas, Museu Arqueológico de S. Miguel de Odrinhas As Troianas de Eurípides, grupo Balbo do IES de Puerto de Santa María (Cádis)

2 de Maio de 2005, 15.30 horas, Pátio Grego da Faculdade de Letras de Lisboa O Persa de Plauto, grupo Balbo do IES. de Puerto de Santa María

4 de Maio de 2005, 11.00 horas, Conimbriga Antígona de Sófocles, grupo Balbo do IES de Puerto de Santa María

4 de Maio de 2005, 15.30 horas, Conimbriga O Persa de Plauto, grupo Balbo do IES de Puerto de Santa María

5 de Maio de 2005, 11.00 horas, Museu Arqueológico de S. Miguel de Odrinhas Electra de Sófocles, produção Festea / Thíasos do IEC

5 de Maio de 2005, 15.30 horas, Museu Arqueológico de S. Miguel de Odrinhas Teócrito e Virgílio, grupo Thíasos do IEC

11 de Maio de 2005, 15.30 horas, Conimbriga Os Dois Menecmos de Plauto, grupo Ágon das Caldas da Rainha

18 de Maio de 2005, 21.30 horas, Conimbriga La serva padrona de G. B. Pergolosi, grupo Canto e Drama do Conservatório de Música de Coimbra.

1 de Junho de 2005, 11.00 horas, Conimbriga Ulisses de Maria Alberta Menéres, grupo Angelus do Colégio de S. Miguel (Fátima)

10 de Junho de 2005, 18.00 horas, Conimbriga A Mulher de Samos de Menandro, grupo Theatro do Lyceu da Figueira da Foz 


\section{FESTIVAL DE VERÃO \\ DE TEATRO DE TEMA CLÁSSICO}

30 de Junho de 2005, 21.45 horas, Teatro Académico Gil Vicente (Coimbra)

Hipólito de Eurípides, Escola Superior de Teatro e Cinema da Amadora

2 de Julho de 2005, 21.45 horas, Pátio da Inquisição (Coimbra)

Teócrito e Virgílio, grupo Thíasos do IEC

5 de Julho de 2005, 21.45 horas, Pátio da Inquisição (Coimbra)

As Mulheres no Parlamento de Aristófanes, grupo Thíasos do IEC

6 de Julho de 2005, 21.45 horas, Auditório Mirita Casimiro (Viseu)

O Soldado Fanfarrão de Plauto, grupo Arthistrión/Calatalifa de Madrid

7 de Julho de 2005, 21.45 horas, Páteo da Universidade de Coimbra

Rei Édipo de Sófocles, grupo Arthistrión/Calatalifa de Madrid

8 de Julho de 2005, 21.45 horas, Pátio da Inquisição (Coimbra)

Filoctetes de Sófocles, grupo Ágon das Caldas da Rainha

9 de Julho de 2005, 21.45 horas, Museu Arqueológico D. Diogo de Sousa (Braga)

Rei Édipo de Sófocles, grupo Arthistrión/Calatalifa de Madrid

10 de Julho de 2005, 21.45 horas, Museu Arqueológico D. Diogo de Sousa (Braga)

As Mulheres no Parlamento de Aristófanes, grupo Thíasos do IEC
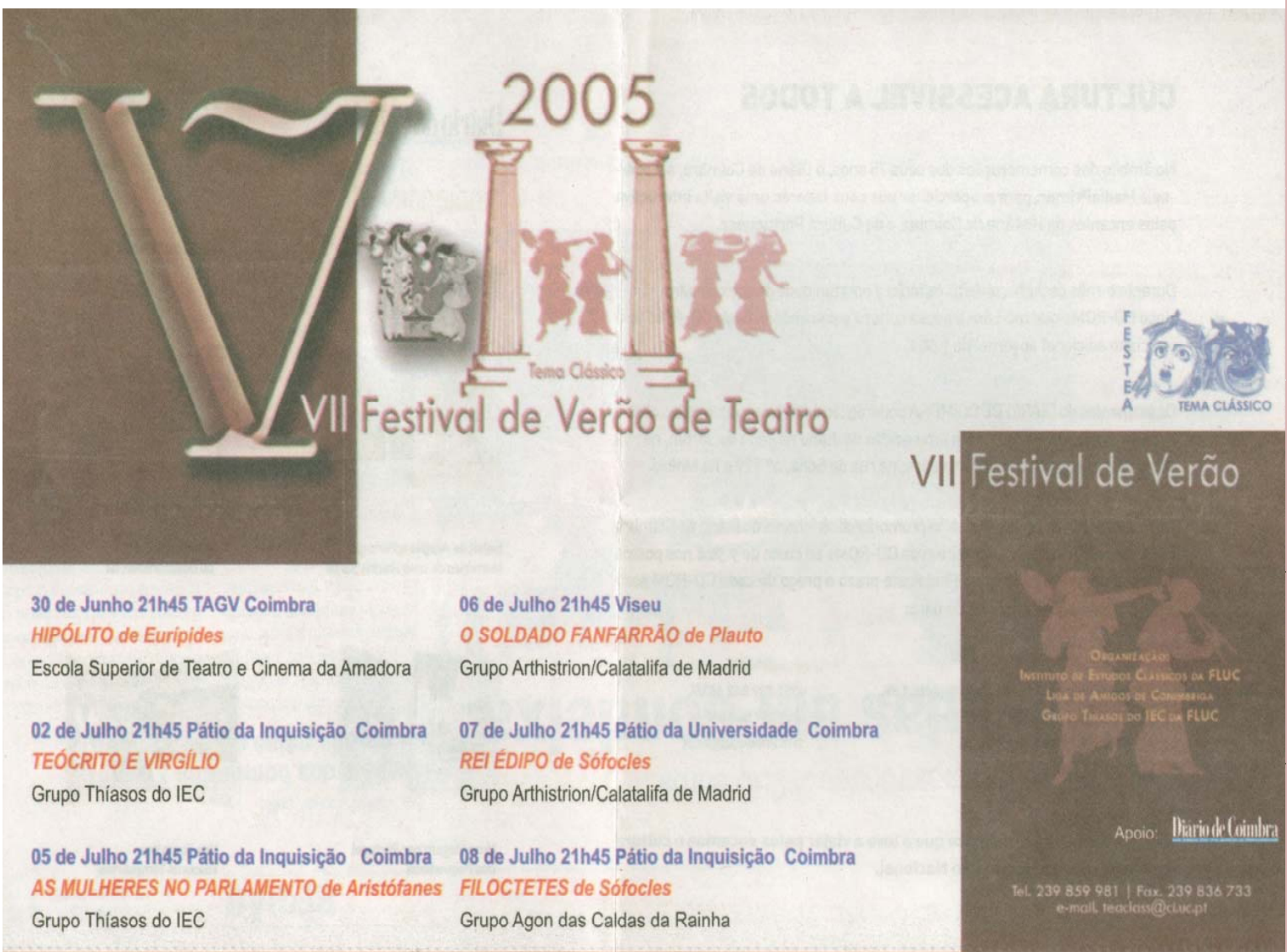

2000
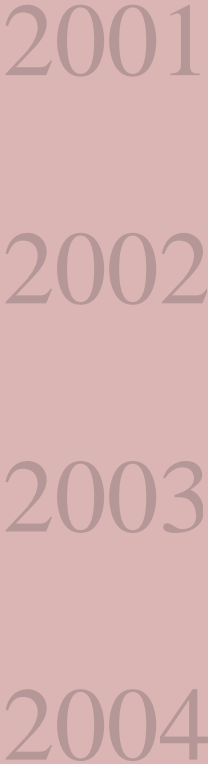

30 de Junho 21 h45 TAGV Coimbra HIPÓLITO de Euripides

Escola Superior de Teatro e Cinema da Amadora

02 de Julho 21h45 Pátio da Inquisição Coimbra TEÓCRITO E VIRGILIO

Grupo Thiasos do IEC

05 de Julho 21 h45 Pátio da Inquisição Coimbra AS MULHERES NO PARLAMENTO de Aristófanes Grupo Thíasos do IEC
06 de Julho 21 h45 Viseu O SOLDADO FANFARRÃO de Plauto Grupo Arthistrion/Calatalifa de Madrid

07 de Julho 21 45 45 Pátio da Universidade Coimbra REI ÉDIPO de Sófocles

Grupo Arthistrion/Calatalifa de Madrid

08 de Julho 21 h45 Pátio da Inquisiçāo Coimbra FILOCTETES de Sófocles

Grupo Agon das Caldas da Rainha
2005
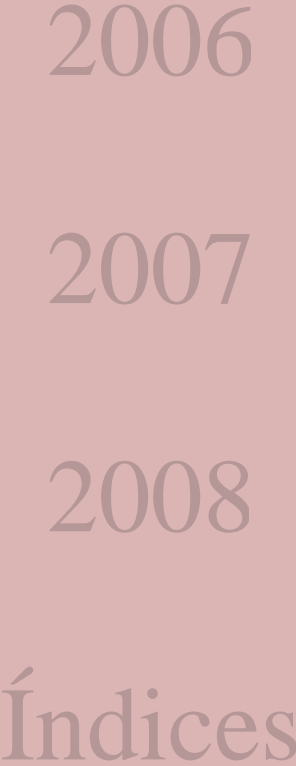
As Mulheres no Parlamento de Aristófanes

Grupo Thíasos do IEC

Tradução

Maria de Fátima Silva

Encenação

José Luís Brandão

Coreografia

Carla Braz

Sonoplastia

Manuel Santos, Luís de Albuquerque

Figurinos

Luísa de Nazaré Ferreira, Inês Santos

Luminotecnia e cenários

Carlos Santos

Caracterização

Vítor Teixeira

Elenco

Verónica Fachada (Praxágora)

José Luís Brandão (Bléfiro)

Delfim Leão (Cremes)

Carlos Jesus (Homem)

\section{Coro}

Sónia Simões, Ângela Leão, Susana Bastos, Carla Braz, Natália Alves, Isabel dos Santos,

Lia Nunes, Ândrea Seiça,

Mariana Matias, Carla Marques,

Ricardo, Ana Catarina Rodrigues
Porque se trata, antes de mais, em As Mulheres no Parlamento, de fazer aprovar uma nova estratégia governativa que revolucione os parâmetros tradicionais, manifestamente ineficazes, da vida política ateniense, Aristófanes encontra nesta comédia uma oportunidade de parodiar de novo o símbolo máximo da vivência democrática da sua cidade: a assembleia do povo. Ao retomar uma temática que havia desenvolvido já na mais antiga das peças que conservamos da sua autoria, Acarnenses, Aristófanes permite-nos constatar, um quarto de século volvido, as mudanças profundas que se haviam operado na vida ateniense, e, do ponto de vista dramático, duas realizações distintas de um mesmo motivo paródico.

Maria de Fátima Silva (da Introdução à tradução)

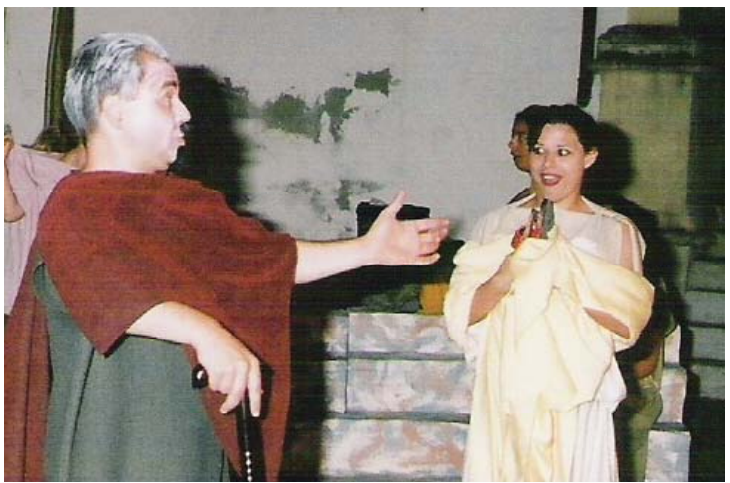

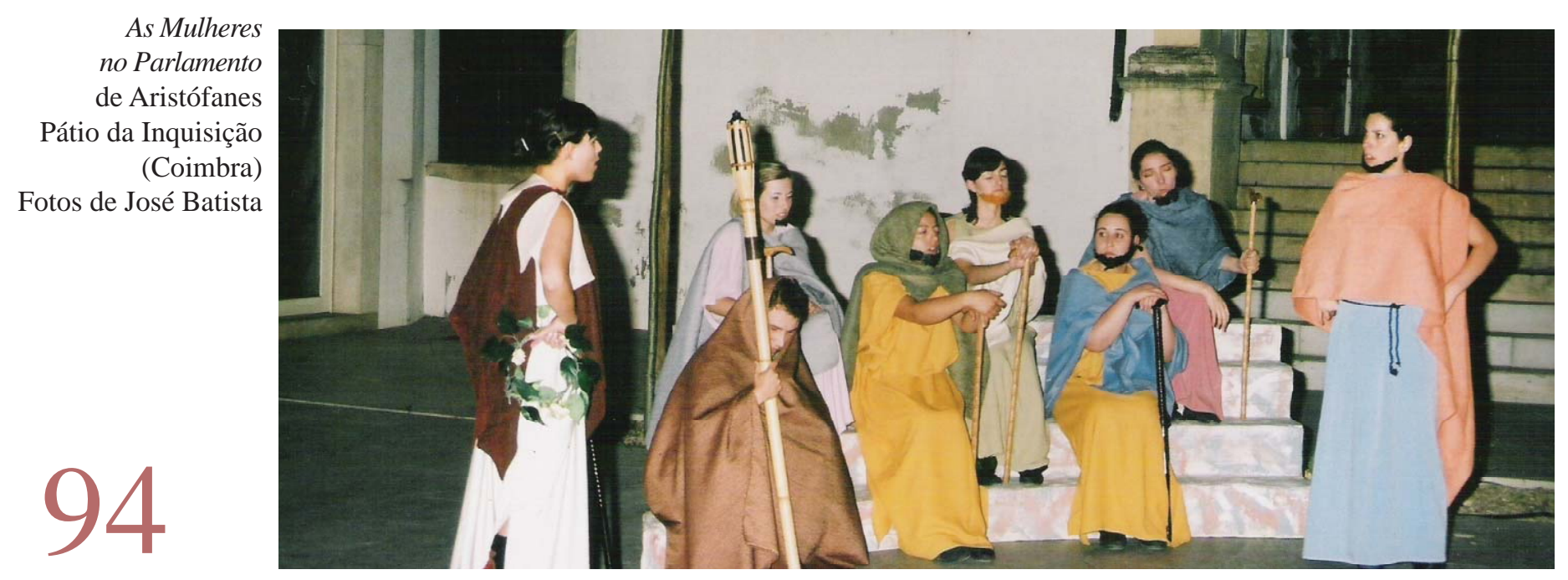






Público

(5 de Junho de 2005)

Texto de M. João Lopes 


\section{Teócrito e Virgílio}

Grupo Thíasos do IEC

\section{Traduções}

M H. Rocha Pereira

M. M. B. du Bocage

\section{Encenação}

Carla Braz, Carlos Jesus

Direcção de actores

Lia Nunes

Coreografia

Maria do Carmo Cruz

Guarda-roupa

Inês Santos

Sonoplastia

Luís Albuquerque

Adereços e luminotecnia

Carlos Santos

\section{Elenco}

Mariana Matias, Lia Nunes,

Carlos Jesus,

Eduardo Conceição, Carmen Luna,

Sara Ribeiro, Isabel dos Santos,

Verónica Fachada, Carla Braz,

Sónia Simões, Carla Marques,

Ana Catarina Rodrigues,

Ândrea Seiça, Ângela Leão

Esta nova peça levada à cena pelo Thíasos veio dar continuidade a uma série de projectos de dramatização de autores não dramáticos, com vista à sua mais fácil apreensão pelo público jovem que é, claramente, o seu alvo.

O Idílio XV de Teócrito, conhecido como “As Siracusanas” e a Bucólica V de Virgílio são desta vez os textos abordados, procurando apresentar duas visões do mimo antigo: a urbana, no caso do autor grego, e a rural, no caso de Virgílio. Além da coincidência de temas que estes poetas nos apresentam, pretende-se dar uma unidade cénica e imagética, na medida em que ambos os textos têm como pano de fundo hinos de glorificação de duas divindades do Amor e da Beleza: Adónis e Dáfnis.

Num primeiro quadro, Praxínoa recebe em casa a amiga Gorgo e, por entre a multidão, tentam chegar ao palácio onde decorrem as Adónias. Ouvem o canto belo e harmonioso de uma mulher argiva. O cenário transforma-se na arcádia mantuana, onde Menalcas e Mopso executam um agon lírico em celebração de Dáfnis. Duas musas, personificando o soar da poesia e do tempo na Natureza, criam o quadro cénico da amena quietude.

Entre a cidade e o campo, entre o mimo urbano e a Arcádia, Teócrito e Virgílio apresentam-se como potenciais autores de palco, quando bem assimilado o forte visualismo e realismo do que escreveram.

do Programa

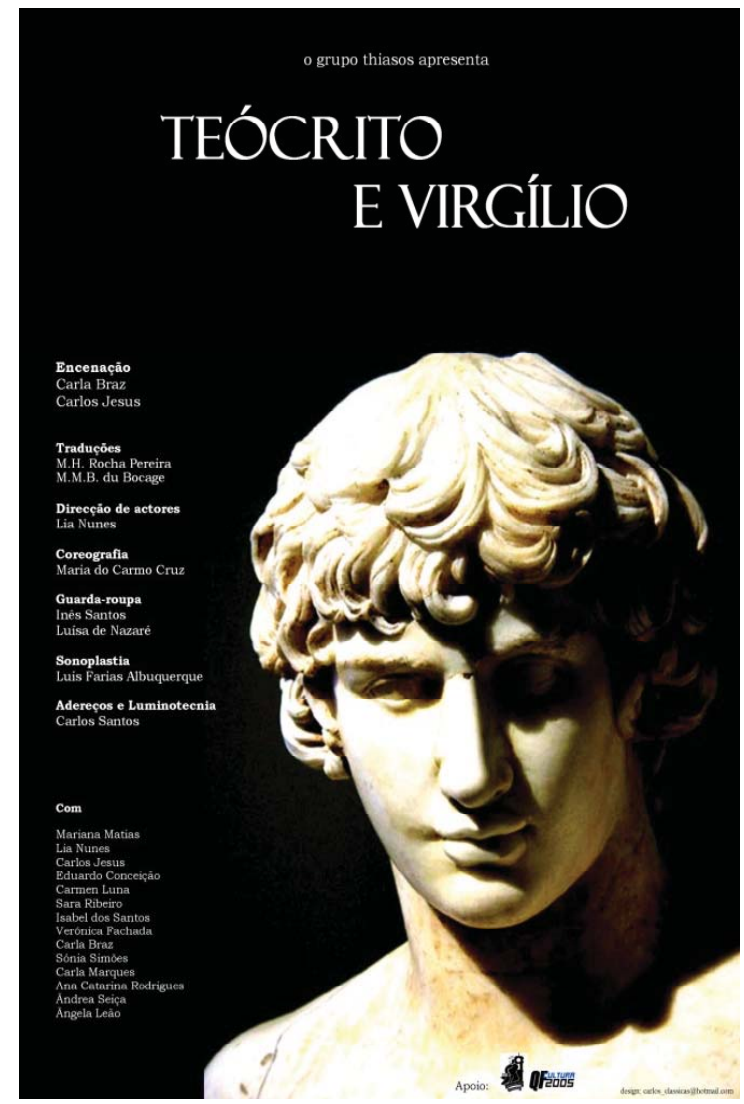



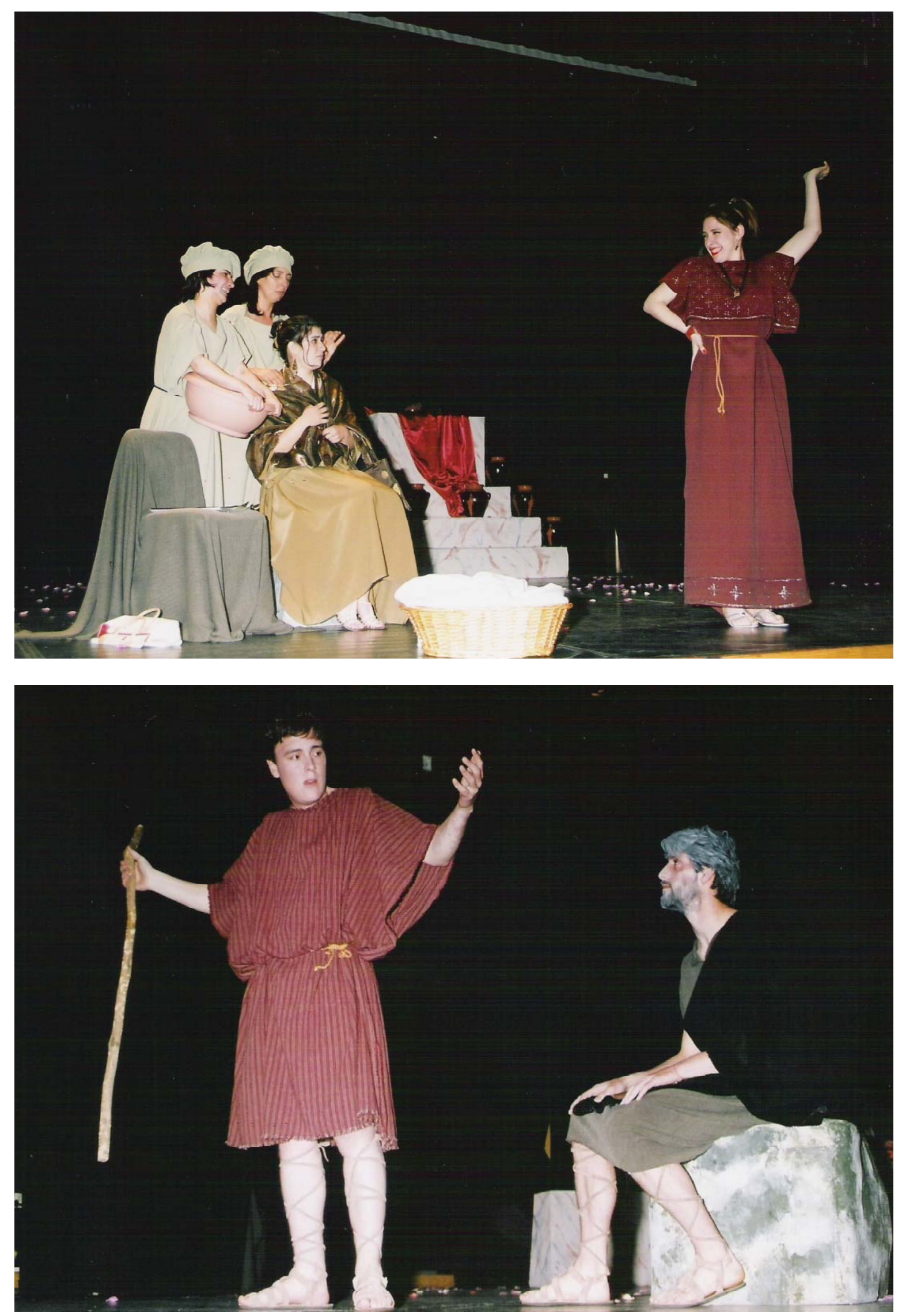

Teócrito e Virgílio

Teatro Paulo Quintela da FLUC

Fotos de José Batista 


\section{Ulisses}

\section{de Maria Alberta Menéres}

Grupo Angelus

Colégio de S. Miguel de Fátima

\section{Encenação}

Nuno Gertrudes, Rui Henriques

Cenografia

Sr. Armando, Carla Luís, Nídia Vieira, Carina Amado, Sandra Pereira, Tiffany Maurício,

Nuno Gertrudes, Rui Henriques

Figurinos

Lídia Pereira, Nuno Gertrudes

Caracterização

Tânia Pereira, Sandra Pereira, Tiffany Maurício

\section{Música}

Rui Sérgio

\section{Selecção Musical}

Nuno Gertrudes, Rui Henriques Elenco

Tiago Costa (Agamémnon) Joel Ferreira (Menelau)

Liliana Fartaria (Penélope)

Nuno Gertrudes (Ulisses)

Joel Ferreira, Márcio Menino, Sara Ferreira

(Marinheiros)

Rui Henriques (Ciclope)

Cidália Eusébio (Euricleia)

Carina Amado (Criada)

Andreia Silva (Minerva)

Mariana Cruz (Circe)

Ana Santos (Nausícaa)

Márcio Menino (Rei Alcínoo)

Elisabete Vieira (Rainha Arete)

Matilde Santos (Mãe de Ulisses)

Jorge Libório (Telémaco)

Jorge Libório, André Fino (Figurantes)
Trata-se de uma obra infanto-juvenil, alicerçada no relato das façanhas de Ulisses, rei grego de Ítaca, durante a viagem de regresso da guerra de Tróia. Por isso, o topos da viagem é talvez o que assume mais relevância no conto, já que a narrativa se desenvolve em torno de um conjunto de episódios, de desafios ou de situações que contribuem para enaltecer, à maneira épica, a figura lendária de Ulisses. Pensemos, por exemplo, na "rendição" de Circe, deusa sedutora e dominadora, que acabou por se dar por vencida face à integridade de Ulisses, "libertando-o" e deixando-o partir, juntamente com os seus companheiros, após ter quebrado o seu feitiço e tê-los feito regressar à forma humana.

E é assim que a singularidade do herói grego se desenha, desde o início, pelo facto de ser um rei dedicado, amante da terra e da família, mas seduzido pelo mar, enquanto espaço de novidade e de desafio. A terra e o mar, ou o que eles representam, interactuam e dividem o herói.

As circunstâncias empurram, no entanto, Ulisses para o mar e é neste (ou em espaços limítrofes) que o herói grego vai viver as aventuras mais insólitas e fantásticas recordem-se, por exemplo, o episódio dos ventos de Eólia à solta, a passagem tenebrosa pela Ilha dos Infernos ou a tentação das Sereias. De todas as adversidades o rei de Ítaca, herói humano protegido pela deusa Minerva, consegue sair vencedor e, por isso, a narrativa finaliza num clima de felicidade e harmonia, muito ao sabor clássico.

do Programa 


\section{Filoctetes \\ a partir de Sófocles \\ Grupo Ágon das Caldas da Rainha}

\section{Adaptação e encenação}

Aníbal Rocha

A caminho de Tróia, para fazer a guerra, Filoctetes foi mordido por uma serpente venenosa. Os chefes seus companheiros, Agamémnon, Menelau e Ulisses abandonaram-no então numa ilha deserta, porque o cheiro da sua ferida e os seus gritos de dor tornavam a viagem insuportável. Filoctetes sobrevive sozinho a esse abandono e à doença graças à sua capacidade de resistência e ao seu arco sagrado, o arco que Héracles lhe dera antes de morrer, caçando animais.

Nove anos depois, quando Aquiles estava já morto, um oráculo diz que Tróia só será vencida com Filoctetes e o seu arco sagrado. Ulisses decide voltar à ilha e, servindo-se de Neoptólemo, o jovem e ingénuo filho de Aquiles, tenta trazer para Tróia Filoctetes com o seu arco. Filoctetes não se quer deixar convencer, ferido como está pela sorte injusta a que foi votado durante tantos anos. Ulisses tenta que o jovem o traga ao engano, convencendo-o de que o está a levar para casa. Mas gera-se uma forte relação entre o rapaz e o envelhecido Filoctetes e é Filoctetes que leva o rapaz a voltar à sua natureza leal e o convence a transportá-lo de volta para a Grécia, abandonando a guerra e os seus chefes traidores.

Só que os deuses não permitem que assim seja: Héracles desce do Olimpo e salva Neoptólemo do seu insolúvel conflito moral ordenando a Filoctetes que vença o seu orgulho e aceite ir para Tróia onde será curado da doença e onde, com o seu arco e flechas sagrados e com o seu jovem companheiro, conseguirá que os Gregos ganhem a guerra.

do Programa
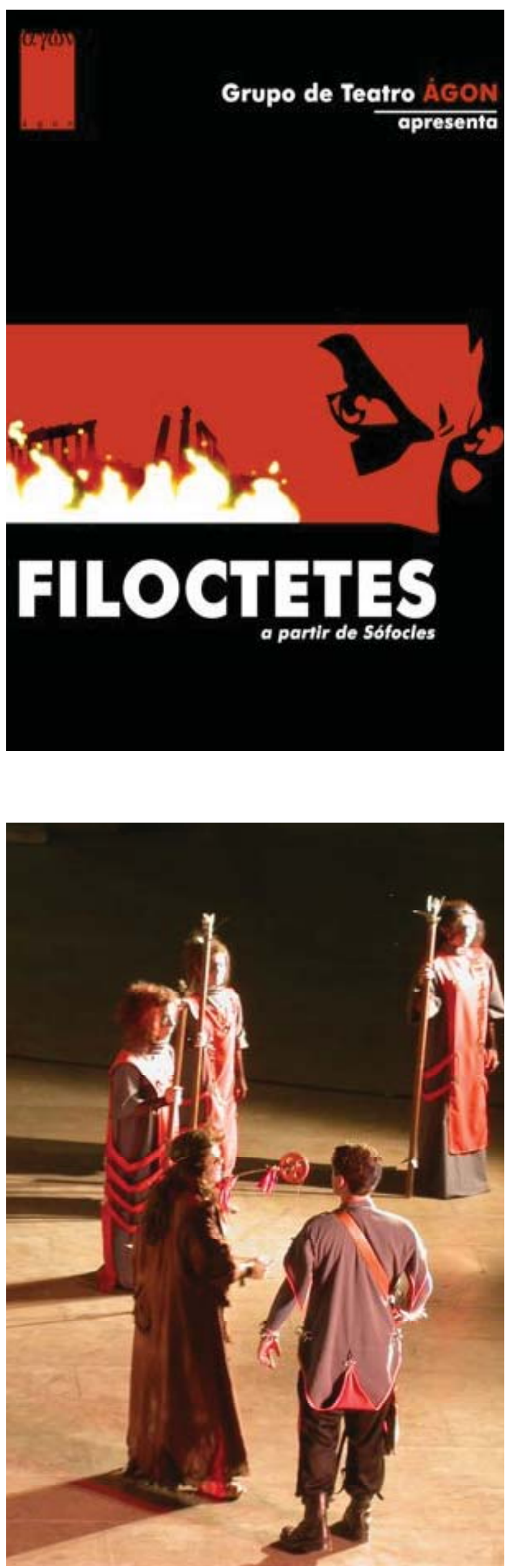

Filoctetes

a partir de Sófocles Pátio da Inquisição (Coimbra)

Fotos do grupo 


\section{O Persa de Plauto}

Grupo Balbo do IES Santo Domingo

de Puerto de Santa María (Cádis)

\section{Encenação}

Emilio Flor Jiménez

Chefe técnico

Adrián Varo

Elenco

Adrián García (Tóxilo)

Jesús María Gutiérrez Torres (Sagaristião)

Juan Lorca Muñoz (Saciadão)

Rocio Lainer Rube (Sofoclidista)

María Torres (Lemniscelene)

Enrique Lainer Rube (Pégnio)

Francisco José Rodríguez Gutiérrez (Dórdalo)

Aída Rodríguez (Donzela)

Prólogo e Bailarinas

Patricia López Ocaña, María Serpa, Inés Higueras López
Esta comédia de Plauto oferece-nos novas situações numa obra onde reinam os escravos. É uma das únicas comédias do dramaturgo onde não aparecem os senhores. Plauto leva-nos ao submundo dos escravos para nos mostrar que também eles se enamoram, lutam entre si, se queixam e se divertem.

Tóxilo é um escravo profundamente apaixonado por Lemniscelene, uma jovem que vive com o malvado alcoviteiro Dórdalo. Para a comprar e fazer sua liberta, pede ajuda ao seu amigo Sagaristião, que se disfarçará de Persa, venderá a filha de Saciadão e obterá o dinheiro necessário para comprar a amada do seu amigo. As histórias de um Saciadão capaz de fazer o que seja para comer, um escravo esquisitóide - Pégnio - assediado por uma velha prostituta Sofoclidisca -, um alcoviteiro ambicioso e um sem fim de bailarinas com muito que mostrar completam a trama desta divertida comédia de enredos.

do Programa

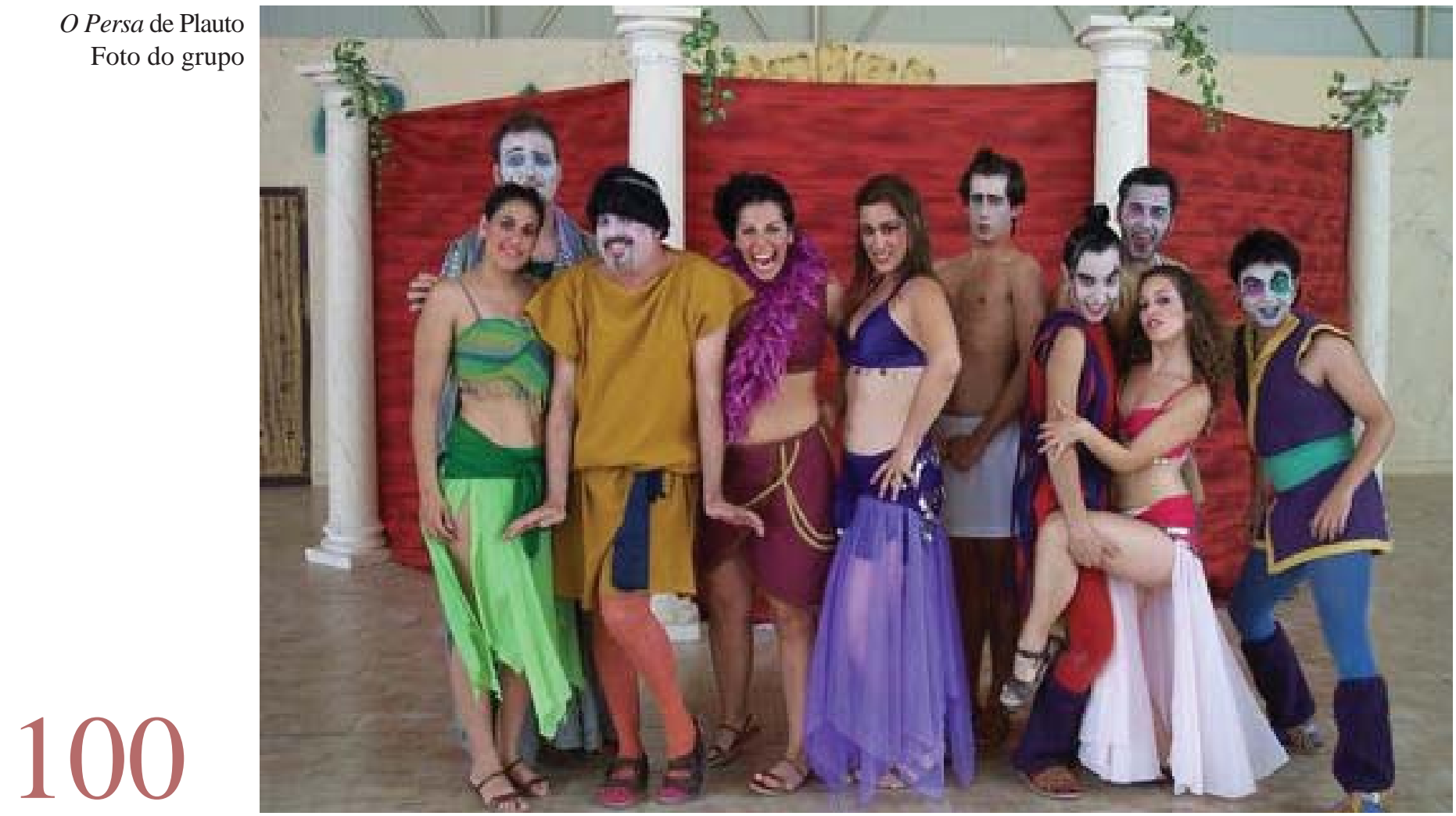




\section{Helena de Eurípides}

Grupo Selene do IES Carlos III de Madrid

\section{Encenação}

José Luis Navarro, Gemma López

\section{Coreografia e figurinos \\ Gemma López}

\section{Confecção do guarda-roupa}

La Soleá

\section{Cenografia}

Tragacanto

Luminotecnia

Carlos Guitart

\section{Elenco}

Bárbara Molina (Helena)

Daniel Ramos (Teucro)

Javier Almazán (Menelau)

Noelia Durán (Serva)

Francisco Alcántara (Primeiro mensageiro)

Alba García (Teónoe)

Vanesa Jurado, Soraya Álvarez

(Séquito de Teónoe)

Juan José Garcés (Teoclímeno)

Juan Carlos Martínez (Segundo mensageiro) Ángel Mera, Antonio Martínez (Dioscuros)

\section{Coro}

Deborah Fernández, Irene Llorente (Corifeu), Gina Patiño, Lidia Ballesteros, Dayana Frías,

Violeta García, Cristina Gamella, Amarantha Pérez, Melody Sánchez, Beatriz

Ginés, Irene Olivas, Estela Campos
Quando Páris raptou Helena de Esparta, antes da Guerra de Tróia, o que levou consigo foi um eidolon dessa mulher, tendo Zeus transportado a verdadeira esposa de Menelau para o Egipto onde, no tempo presente da acção da tragédia, o rei Teoclímeno quer desposá-la. Teucro encontra Helena e fala-lhe do término da guerra. Menelau, voltando para Esparta com o fantasma de Helena, naufraga ali perto. Os dois esposos encontram-se, reconhecem-se e, com a ajuda de Teónoe, arquitectam a fuga do Egipto.

do Programa

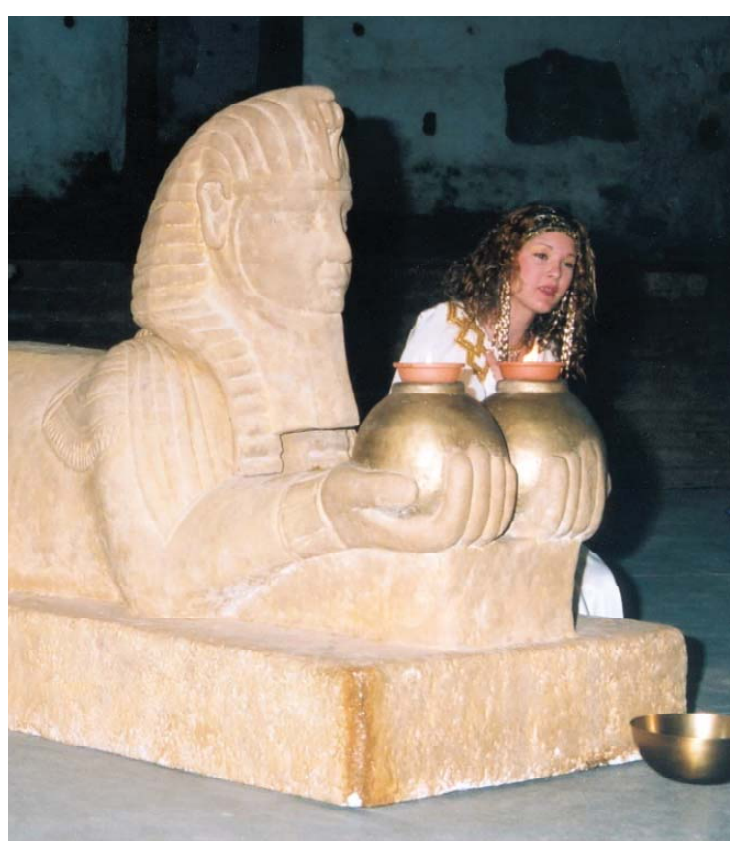

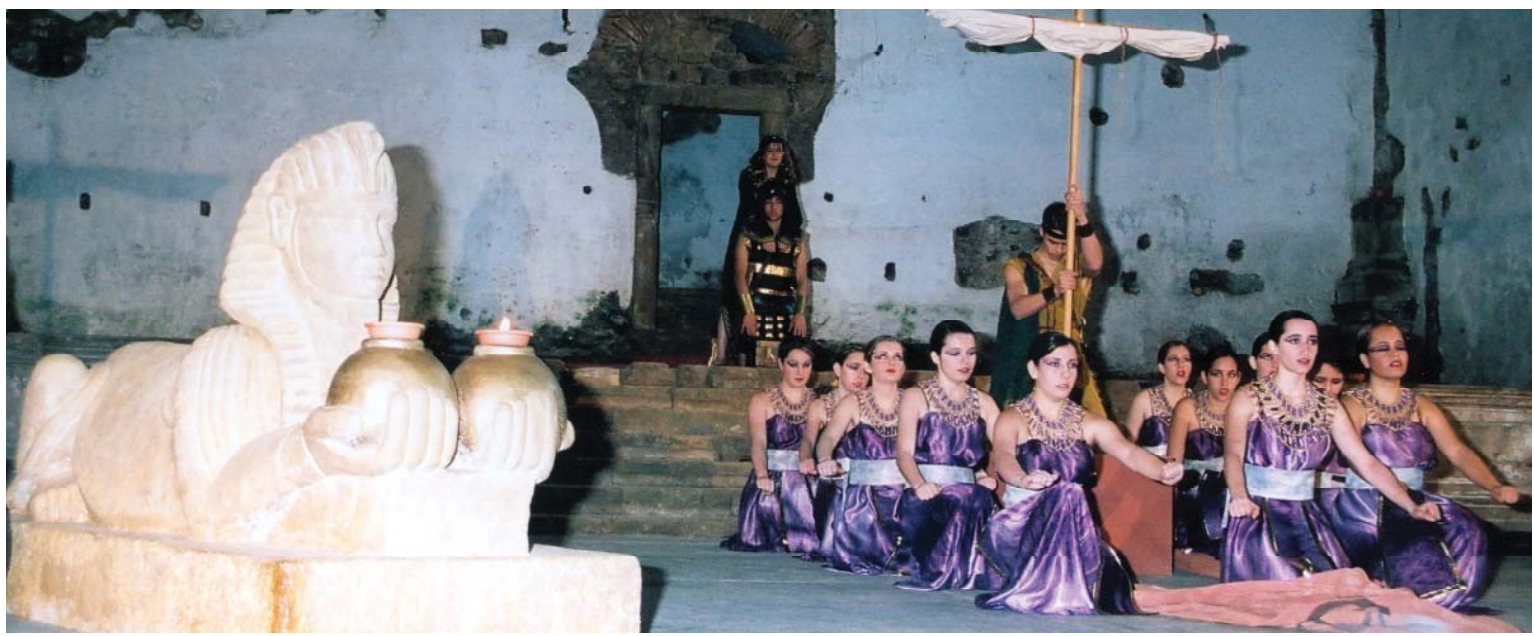


Helena de Eurípides

Convento de S. Francisco (Coimbra)

Fotos de José Batista

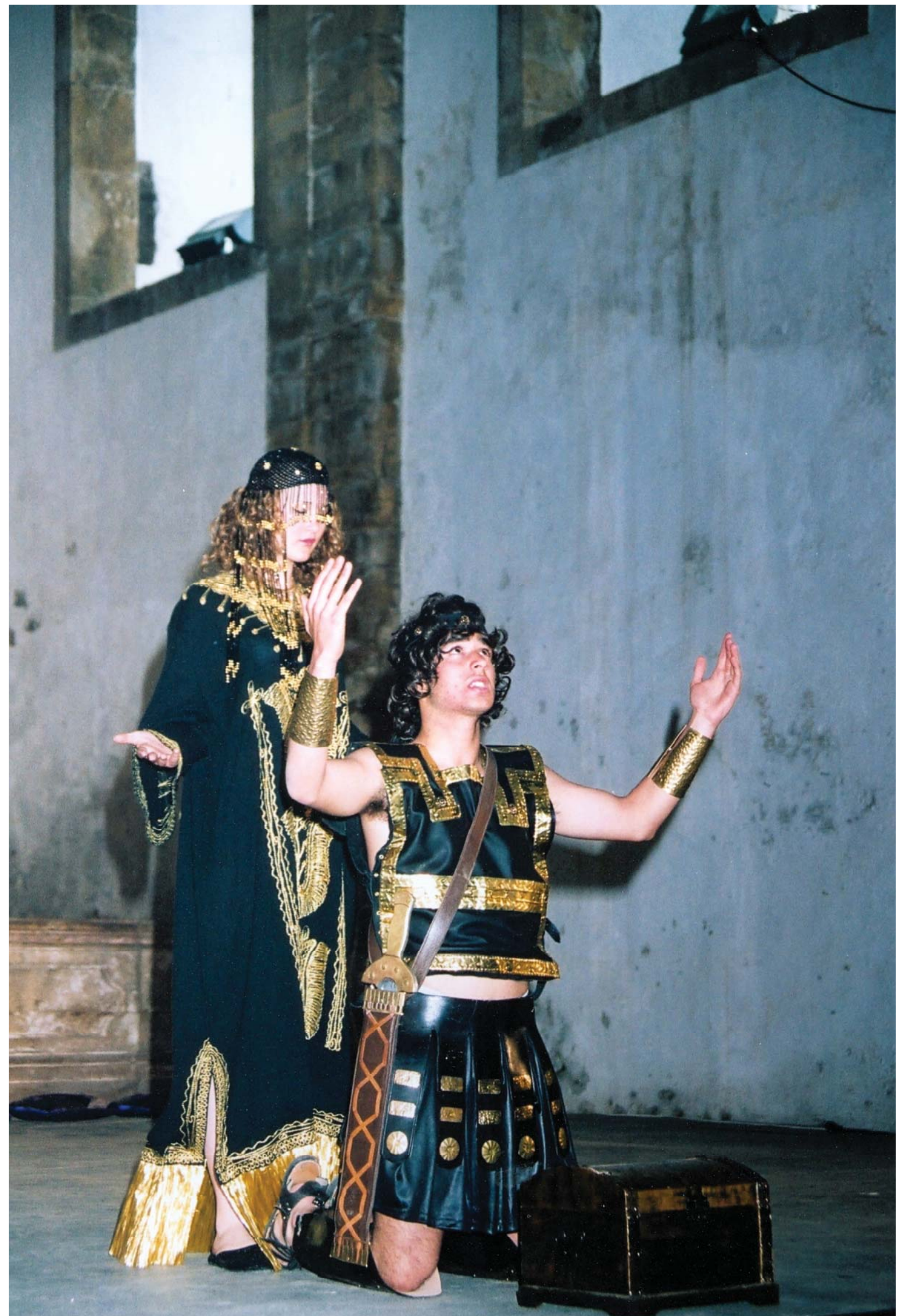




\section{Pluto (A Riqueza) de Aristófanes}

Grupo Selene do IES Carlos III de Madrid

\author{
Encenação \\ José Luis Navarro, Gemma López \\ Luminotecnia \\ Carlos Guitart \\ Adereços \\ Tragacanto \\ Jesús López Salinero \\ Guarda-roupa e coreografia \\ Gemma López \\ Elenco \\ Antonio Martínez (Caríon) \\ Ángel Mera (Crémilo) \\ Miguel Sarrión (Pluto) \\ Juan José Garcés (Blepsidemo) \\ Bárbara Molina (Pénia) \\ Raquel de la Varga (Mulher de Crémilo) \\ Juan Carlos Martínez (Homem Justo) \\ Francisco Alcántara (Sicofanta) \\ Yolanda Alonso (Velha) \\ Javier Almazán (Jovem) \\ Daniel Ramos (Hermes) \\ Vanesa Millán (Sacerdotisa) \\ Violeta García (Riqueza) \\ Laura Ruíz, Irene Llorente (Moedas)

\section{Coro} \\ Gina Patiño, Vanesa Jurado, \\ Noelia Durán, Alba García, Mónica Rubio, \\ Dayana Frías, Deborah Fernández, \\ Lydia Ballesteros, Cristina Gamella, \\ Melody Sánchez
}

Crémilo, um velho de poucos recursos, vai ao templo do deus perguntar de que modo poderia levar uma vida mais próspera e cómoda. Eis a resposta que lhe dá o oráculo: que, logo que saia do templo, acompanhe o primeiro fulano que lhe apareça à frente. É assim que encontra um velho cego, de aspecto miserável. Acompanha-o, de acordo com o oráculo, e esse velho calha ser Pluto (a Riqueza). O escravo que vai com ele, Caríon, em breve deixará de fazer troça do amo, mal ouça da boca do cego a sua identidade. Crémilo, orgulhoso do seu feito, manda chamar os companheiros do campo para que tomem parte da sua alegria. Assim entra em cena o coro.

Crémilo decide levar Pluto ao templo de Asclépio para que recupere a vista e todos possam desfrutar da riqueza. Sentindo-se prejudicada, Pénia (a Pobreza) surge a insultar todos quantos trataram do assunto e tem lugar um diálogo de grande qualidade, por Blepsidemo e Crémilo, que põe lado a lado a carência de Pénia e as dádivas de Pluto.

do Programa

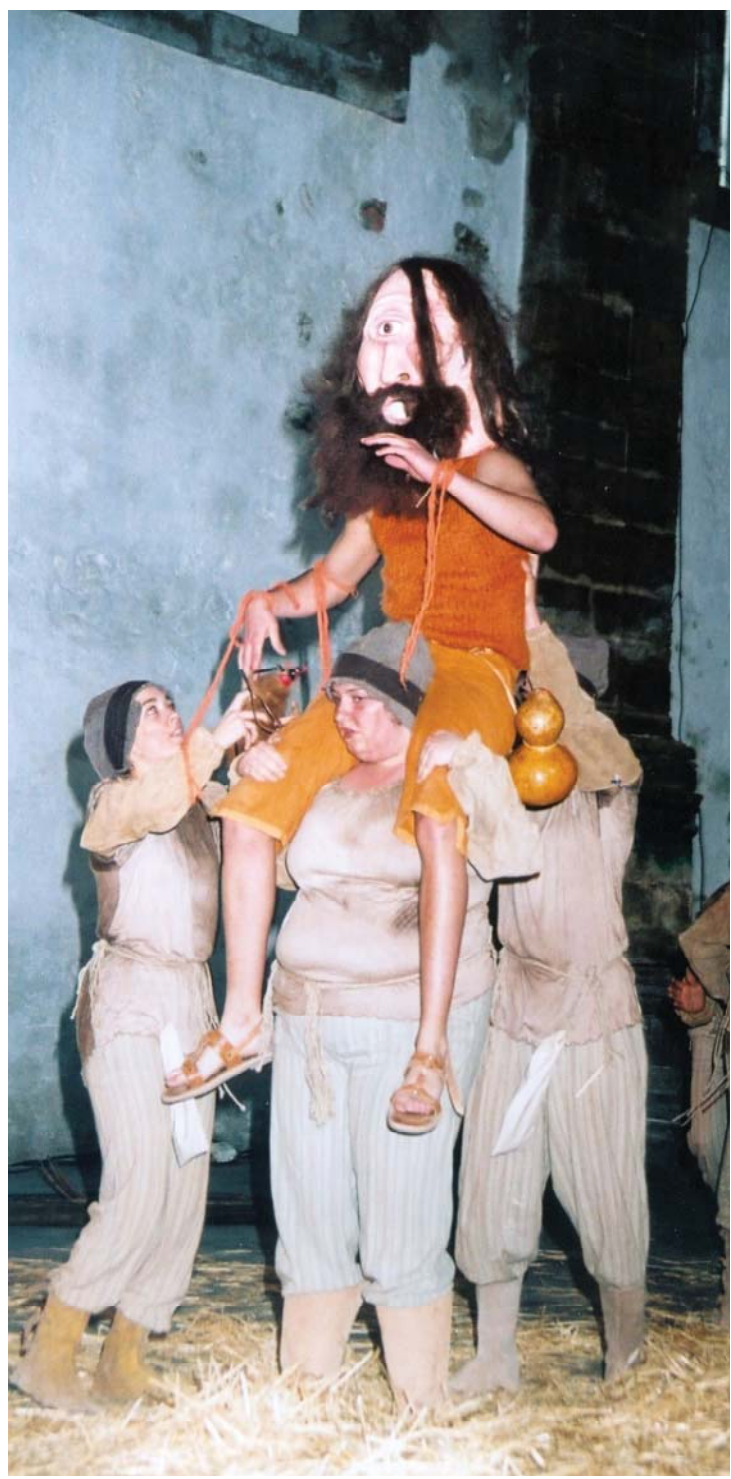



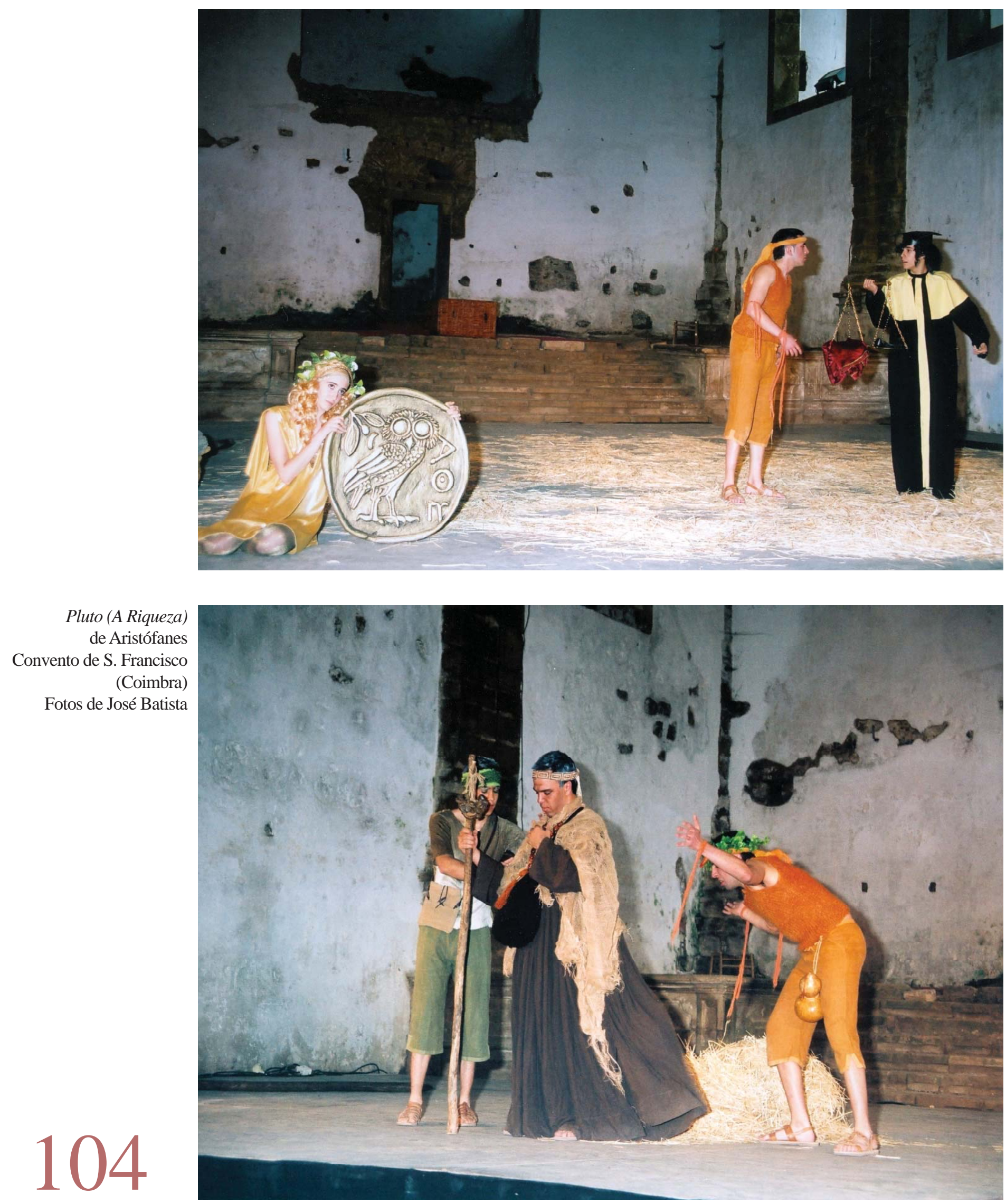


\section{Hipólito de Eurípides}

Departamento de Teatro

da Escola Superior de Teatro e Cinema da Amadora

Espectáculo dos alunos finalistas do Bacharelato dos Cursos de Teatro e Formação de Actores e Realização Plástica do Espectáculo

\section{Direcção \\ Nuno Cardoso \\ Dramaturgia \\ David Antunes \\ Corpo}

Luca Aprea

Voz

Maria Repas

Realização plástica do espectáculo

Vera Castro

Coordenação de cenário

António Polainas

\section{Cenário}

Nuno Barracas

Figurinos

Joana Paes de Freitas, Sandra Catarino

Desenho de luz e coordenação técnica

Vasco Ferreira

Sonoplastia

Domingos Morais

Operação de luz e som

Joana Serra

Elenco

Cláudia Chéu, Elmano Sancho, Hugo Bettencourt, John Romão,

Leonor Cabral, Margarida Teixeira, Maria Ladeira, Mia Farr, Rute Cardoso, Teresa Arriaga
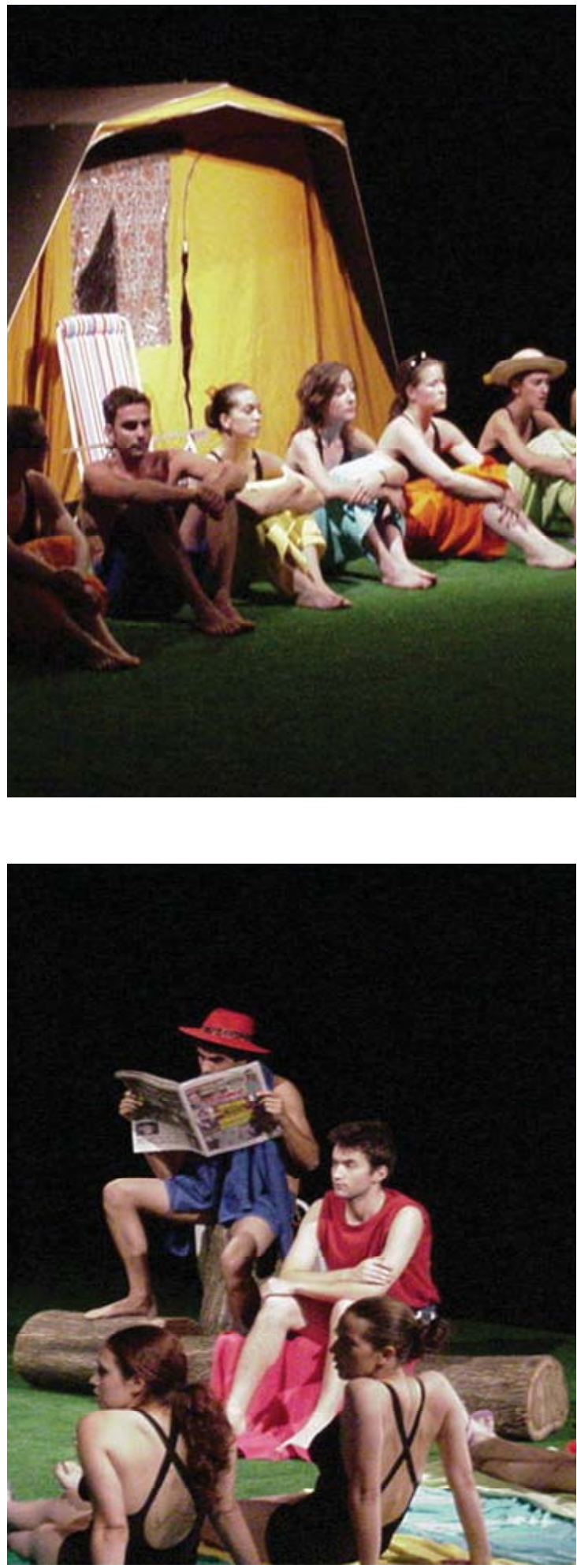

Hipólito de Eurípides Fotos do grupo 
3 de Abril de 2006, 21.30 horas, Teatro Paulo Quintela da Faculdade de Letras de Coimbra Teócrito e Virgílio, grupo Thíasos do IEC

26 de Abril de 2006, 11.00 horas, Teatro Paulo Quintela da Faculdade de Letras de Coimbra Suplicantes de Eurípides, grupo Thíasos do IEC

26 de Abril de 2006, 15.30 horas, Teatro Paulo Quintela da Faculdade de Letras de Coimbra As Mulheres no Parlamento de Aristófanes, grupo Thíasos do IEC

3 de Maio de 2006, 15.30 horas, Pátio Grego da Faculdade de Letras de Lisboa As Mulheres no Parlamento de Aristófanes, grupo Thíasos do IEC

4 de Maio de 2006, 11.00 horas, Museu Arqueológico de S. Miguel de Odrinhas Antígona de Sófocles, grupo Balbo do IES Santo Domingo de Puerto de Santa María (Cádis)

4 de Maio de 2006, 15.30 horas, Museu Arqueológico de S. Miguel de Odrinhas Soldado Fanfarrão de Plauto, grupo Balbo do IES Santo Domingo de Puerto de Santa María (Cádis)

5 de Maio de 2006, 11.00 horas, Mosteiro de S. Martinho de Tibães Antígona de Sófocles, grupo Balbo do IES Santo Domingo de Puerto de Santa María (Cádis)

5 de Maio de 2006, 15.30 horas, Mosteiro de S. Martinho de Tibães Soldado Fanfarrão de Plauto, grupo Balbo do IES Santo Domingo de Puerto de Santa María (Cádis)

13 de Maio de 2006, 21.00 horas, Auditório Mirita Casimiro (Viseu) As Mulheres no Parlamento de Aristófanes, grupo Thíasos do IEC

15 de Maio de 2006, 15.30 horas, Museu Arqueológico de S. Miguel de Odrinhas Suplicantes de Eurípides, grupo Thíasos do IEC

16 de Maio de 2006, 21.30 horas, Museu Nacional Machado de Castro Suplicantes de Eurípides, grupo Thíasos do IEC

19 de Maio de 2006, 11.30 horas, Museu Monográfico de Conimbriga Suplicantes de Eurípides, grupo Thíasos do IEC

19 de Maio de 2006, 15.30 horas, Museu Monográfico de Conimbriga As Mulheres no Parlamento de Aristófanes, grupo Thíasos do IEC

20 de Maio de 2006, 21.30 horas, Museu Monográfico de Conimbriga Orfeu e Eurídice de Gluck, grupo Canto e Drama do Conservatório de Música de Coimbra 
5 de Julho de 2006, Conimbriga

Encontros do Efémero

6 de Julho de 2006, 21.30 horas, Auditório Mirita Casimiro (Viseu)

O Persa de Plauto, grupo Balbo do IES Santo Domingo de Puerto de Santa María (Cádis)

7 de Julho de 2006, 21.30 horas, Páteo da Universidade de Coimbra

O Persa de Plauto, grupo Balbo do IES Santo Domingo de Puerto de Santa María (Cádis)

8 de Julho de 2006, 21.30 horas, Largo da Sé de Braga

Soldado Fanfarrão de Plauto, grupo Balbo do IES Santo Domingo de Puerto de Santa María (Cádis)

9 de Julho de 2006, 21.30 horas, Largo da Sé de Braga

Suplicantes de Eurípides, grupo Thíasos do IEC

11 de Julho de 2006, 21.30 horas, Conimbriga

As Mulheres no Parlamento de Aristófanes, grupo Thíasos do IEC

13 de Julho de 2006, 21.30 horas, Museu Nacional Machado de Castro

Gorgulho de Plauto, grupo Angelus do Colégio de S. Miguel (Fátima)

\section{ENCONTROS DO EFÉMERO}

\section{"Êxtase dionisíaco: a construção da personagem enquanto processo de alienação"}

Jornada de reflexão teórica e prática sobre o teatro. A designação adoptada para estes encontros visou, antes de mais, salientar a dimensão única e irrepetível de cada experiência teatral e por conseguinte efémera, cuja perenidade é garantida não pelo registo fotográfico ou fílmico, mas antes pela impressão indelével deixada na memória do espectador, bem como pelo desafio contínuo de revisitar obras paradigmáticas, dando voz, cor e movimento aos grandes textos. "Efémero” é também, à letra, tudo “o que dura um dia apenas”, de modo que estes encontros foram idealizados para se estenderem somente por um período máximo de 24 horas seguidas, durante as quais os participantes foram convidados a seguir um trajecto que se alargou desde a abordagem teórica de alguns aspectos ligados à arte performativa até à experiência iniciática da construção da personagem.

Manhã: enquadramentos teóricos

- Delfim Leão: "Ephemeron theama”, abertura dos Encontros;

- José Ribeiro Ferreira: “O ritual dionisíaco”.

Tarde: processos de montagem do espectáculo

- Bacantes de Eurípides (na encenação de Fernanda Lapa, apresentada pela própria);

- Antígona de Sófocles (por actores do grupo Balbo de Cádis).

Noite: representação da Antígona de Sófocles, pelo grupo Balbo, no novo teatro ao ar livre de Conimbriga.

Serão: experiência de alienação e construção da personagem, a partir das Bacantes de Eurípides. 


\section{As Suplicantes de Eurípides}

Grupo Thíasos do IEC

\author{
Tradução
}

José Ribeiro Ferreira

Encenação

Carlos Jesus, Carla Braz

Consultor

José Luís Brandão

Figurinos

Maria João Antunes, Inês Santos

\section{Sonoplastia}

Luís Albuquerque

Cenografia

Carlos Santos

\section{Luminotecnia}

Carlos Santos

Elenco

Ângela Leão (Etra)

Luís Marques Cruz (Teseu)

Artur Magalhães (Adrasto)

Carlos Jesus (Mensageiro ateniense)

Vitor Teixeira (Mensageiro argivo)

Nélson Ferreira (Ífis)

Sónia Simões, Patrícia Ligeiro (Evadne)

Coro

Carla Braz (Corifeu), Susana Bastos, Ândrea

Seiça, Patrícia Ligeiro, Carla Rosa, Carla

Correia, Susana Rosa, Verónica Fachada
As Suplicantes, representadas no contexto da Guerra do Peloponeso (431-404 a.C.), resultam numa acutilante e sofrida reflexão sobre as consequências da guerra, de todos os tempos. O coro que dá o título à peça é constituído pelas mães dos sete generais que pereceram no cerco de Tebas, aliados de Polinices quando este pretendeu recuperar o poder ao irmão Etéocles. Em termos mitológicos, portanto, a peça vem no seguimento directo dos Sete Contra Tebas de Ésquilo, do Édipo em Colono de Sófocles e das Fenícias de Eurípides, tratando tema idêntico ao da Antígona de Sófocles - o dever de prestar honras fúnebres aos mortos. O mito é já, contudo, um marco central no Ciclo Épico, com as obras Tebaida e Epígonos, de que nos chegaram apenas escassos fragmentos.

O pano de fundo da peça é o santuário de Elêusis, ao qual se deslocam Adrasto, velho rei dos Argivos, e as sete mães suplicantes, para pedir a Etra que convença o filho Teseu a reclamar junto de Creonte os corpos mortos dos sete generais. Relutante a início, Teseu aceita a tarefa. Chega entretanto um arauto tebano que anuncia a vontade contrária de Creonte, o que leva o rei de Atenas a partir para Tebas com um exército, que sai vitorioso. Os cadáveres entram depois em cena e, quando as mães os depositam
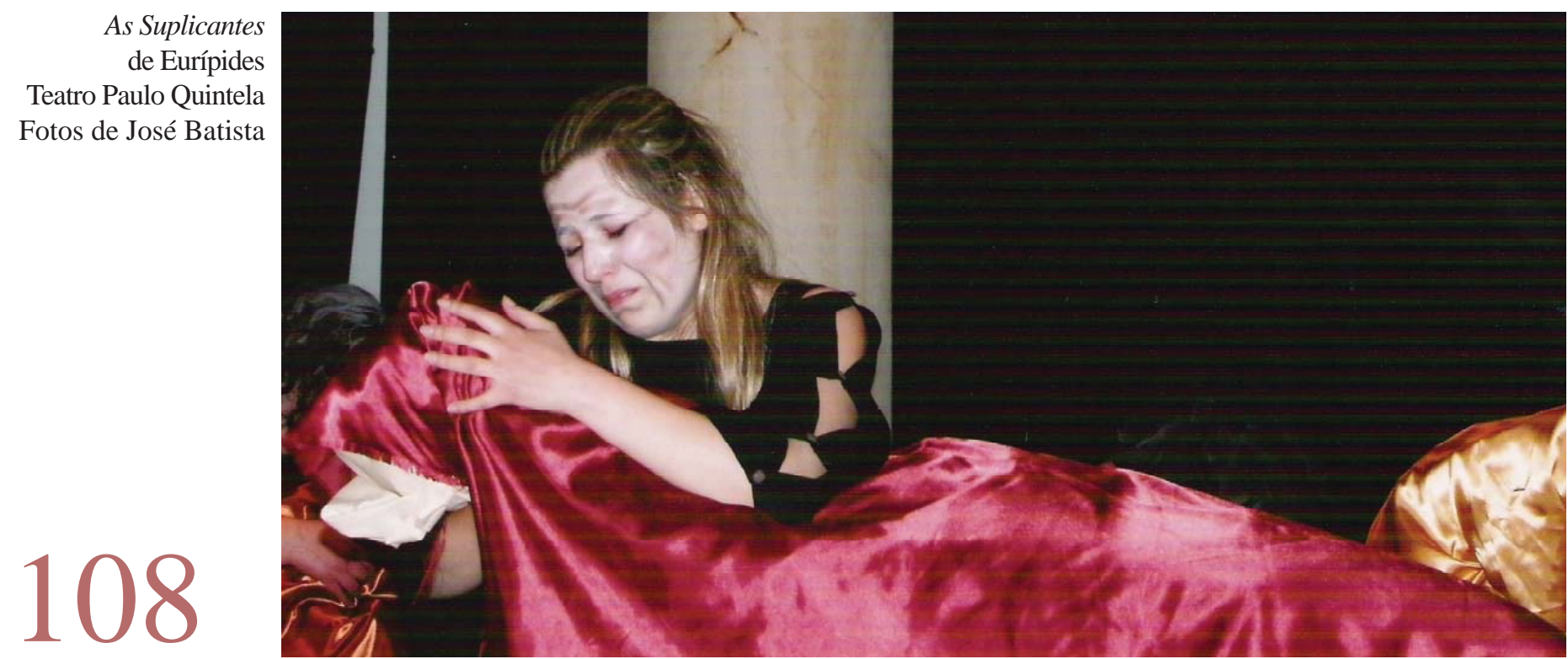
na pira, surge Evadne, viúva de Capaneu, que, em delírio de bacante, deseja morrer com o marido. Apesar dos pedidos do pai, ela acaba por se suicidar e arder com o marido, nas chamas que considera o seu leito nupcial. Num happy end tipicamente euripidiano, surge ex machina a deusa Atena, formalizando o pacto de amizade entre Argivos e Atenienses.

A guerra (justa e injusta), a morte, o amor e a defesa da Democracia são estes os grandes temas que Eurípides apresenta e discute em Suplicantes. Uma peça nem sempre fácil de colocar em cena, mas cuja mensagem - grande mérito da tragédia clássica - é de todos os tempos.

do Programa

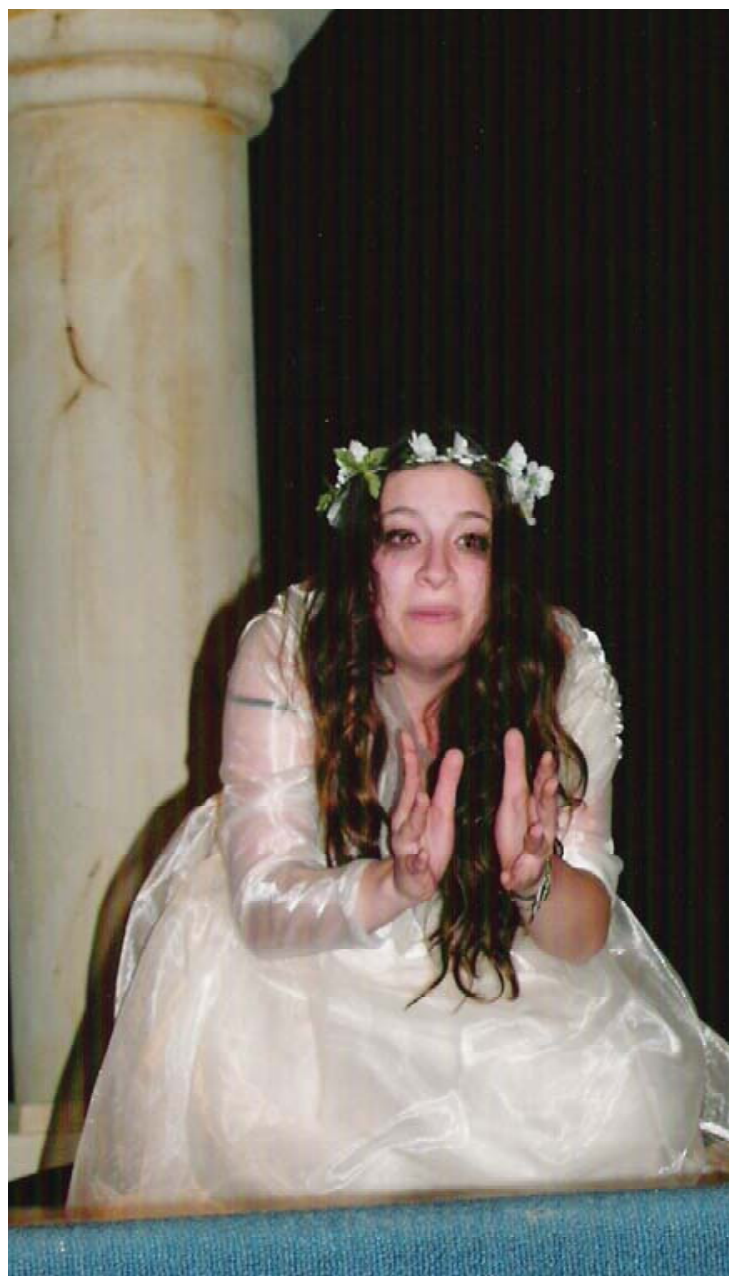

\section{O Soldado Fanfarrão de Plauto}

Grupo Balbo do IES Santo Domingo de

Puerto de Santa María, Cádis

\author{
Encenação \\ Emilio Flor Jiménez, Jose Pecho \\ Cenografia e figurinos \\ Javier Fonseca \\ Luminotecnia \\ Joaco Arjona \\ Música original \\ Alberto Barea \\ Adereços \\ Sucesores de Ángel Martínez S.L. \\ Elenco \\ Paco Crespo (Pirgopolinices) \\ Jose Pecho (Artotrogo, Céledro) \\ Jesús Torres (Palestrião) \\ Fran Rodríguez (Periplectómeno) \\ Nanpéh (Filocomásio) \\ Olga Barba (Acrotelência) \\ Inés Higueras (Milfidipa)
}

Pirgopolinices, soldado mulherengo e fanfarrão, elogiado nas suas batalhas pelos escravos, rapta uma bela cortesã, Filocomásio, e leva-a para sua casa, longe de Roma. Palestrião, o jovem escravo do amante de Filocomásio, acaba por ser também raptado pelo soldado, mas tudo faz para que o seu antigo senhor saiba do paradeiro da cortesã. Consegue que Periplectómeno, um velho vizinho do soldado, hospede o jovem enamorado em sua casa e faz um buraco no muro que separa os dois edifícios para que os namorados se encontrem.

Mas tudo descamba quando um escravo tolo descobre os dois amantes. A partir daí, Palestrião trama uma série de intrigas e enganos para castigar o soldado fanfarrão e de novo zarparem todos para Roma.

do Programa 
26 de Abril de 2007, 21.30 horas, Teatro Paulo Quintela (FLUC) Agamémnon de Ésquilo, grupo Thíasos do IEC

1 de Maio de 2007, 16.00 horas, Miranda do Corvo Lisístrata de Aristófanes, grupo Calatalifa de Madrid

2 de Maio de 2007, 21.30 horas, Auditório Mirita Casimiro (Viseu) Comédia dos Burros de Plauto, grupo Calatalifa de Madrid

11 de Maio de 2007, Festival Européen Latin et Grec 2007 (Nantes, França) As Mulheres no Parlamento de Aristófanes, grupo Thíasos do IEC

16 de Maio de 2007, 11.00 horas, Museu Arqueológico de S. Miguel de Odrinhas Agamémnon de Ésquilo, grupo Thíasos do IEC

16 de Maio de 2007, 15.30 horas, Museu Arqueológico de S. Miguel de Odrinhas As Mulheres no Parlamento de Aristófanes, grupo Thíasos do IEC

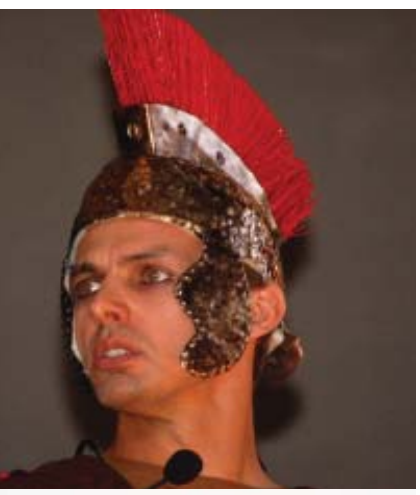

19 de Maio de 2007, 17.00 horas, Conimbriga Gorgulho de Plauto, grupo Angelus do Colégio de S. Miguel (Fátima)

20 de Maio de 2007, 21.30 horas, Conimbriga Vénus e Adónis de John Blow, grupo Canto e Drama do Conservatório de Música de Coimbra

5 de Julho de 2007, 21.30 horas, Páteo da Universidade da Coimbra Hécuba de Eurípides, grupo Selene do IES Carlos III de Madrid

6 de Julho de 2007, Conimbriga Encontros do Efémero II

7 de Julho de 2007, 21.30 horas, Museu D. Diogo de Sousa (Braga) Hécuba de Eurípides, grupo Selene do IES Carlos III de Madrid

8 de Julho de 2007, 21.30 horas, Termas Romanas de Braga Agamémnon de Ésquilo, grupo Thíasos do IEC

10 de Julho de 2007, 21.30 horas, Páteo da Universidade de Coimbra Suplicantes de Eurípides, grupo Thíasos do IEC

11 de Julho de 2007, 21.30 horas, Viseu Suplicantes de Eurípides, grupo Thíasos do IEC

12 de Julho de 2007, 21.30 horas, Conimbriga Agamémnon de Ésquilo, grupo Thíasos do IEC

13 de Julho de 2007, 21.30 horas, Miranda do Corvo As Mulheres no Parlamento de Aristófanes, grupo Thíasos do IEC 
Embora, em anos anteriores, a associação Festea organizasse dois festivais temáticos por edição, optou a partir do ano de 2007 por juntar as valências do Festival Escolar e do Festival de Verão numa única iniciativa, mantendo embora os mesmos propósitos educativos e culturais. Entre estes objectivos, destacam-se o carácter itinerante do festival, a revitalização de espaços com interesse arqueológico e monumental, o estímulo à leitura através da disponibilização do livro-bilhete para todas as representações e ainda a realização de oficinas de teatro orientadas para a formação de jovens artistas. Com esta concentração num só festival (que decorreu nos meses de Abril, Maio e Julho), a organização conseguiu economizar alguns recursos e sobretudo garantir maior coesão ao programa geral.

No conjunto, foram realizados 15 espectáculos, 14 dos quais de teatro e 1 de música, repartidos por 8 produções distintas. Houve 5 grupos envolvidos (3 portugueses e 2 espanhóis), que se propuseram abordar obras de grandes autores como Aristófanes, Ésquilo, Sófocles, Eurípides, Plauto ou John Blow. Uma vez que é propósito do Festival unir o espectáculo à reflexão sobre as próprias artes performativas, houve ainda um dia inteiro dedicado a oficinas de teatro (Encontros do Efémero II), realizado novamente em Conimbriga.

Em consequência da concentração do Festival Escolar e do Festival de Verão numa só iniciativa, o número de espectáculos apresentados foi mais reduzido, mas conseguiu ainda assim uma média de cerca de 200 espectadores por cada performance, ultrapassando os 3000 no total. De ressaltar em especial a excelente penetração em locais como Braga, Viseu e Sintra (S. Miguel de Odrinhas), onde se chegou mesmo a ultrapassar os 300 espectadores em algumas das apresentações. A este resultado francamente positivo não é alheio o facto de, nesses lugares, se ter procurado articular o teatro clássico com outras iniciativas culturais já recorrentes (como o Festival de Teatro Jovem e o Viseu naturalmente, em Viseu, e o Mimarte, em Braga).

É ainda de salientar dois aspectos importantes; por um lado, o Thíasos teve a honra de haver sido convidado para participar no Festival Européen Latin et Grec 2007 (Nantes, França), cimentando os contactos a nível internacional; por outro, Miranda do Corvo juntou-se aos locais onde o festival procura ter uma presença regular, acentuando assim o seu carácter itinerante e o esforço de descentralização.

2000
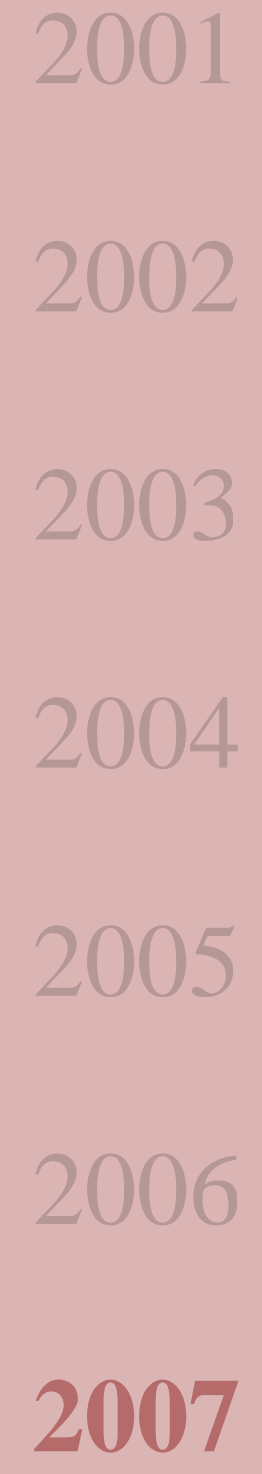

Delfim Ferreira Leão 


\section{Agamémnon de Ésquilo}

Grupo Thíasos do IEC

\section{Tradução}

Manuel de Oliveira Pulquério

\section{Encenação}

Lia Nunes

Sonoplastia

Tiago Cabral

\section{Luminotecnia}

Carlos Santos, Vitor Teixeira

\section{Coreografia}

Andreia Paixão

Figurinos

Maria João, Inês Santos

\section{Elenco}

Delfim Leão (Agamémnon)

Sónia Simões, Ângela Leão (Clitemnestra)

Patrícia Ligeiro (Cassandra)

Nelson Ferreira (Egisto)

Mário Pais, Ândrea Seiça (Vigia)

\section{Coro}

Carlos Jesus (Corifeu),

Artur Magalhães, Ândrea Seiça,

Luís Albuquerque, Joana Militão,

Linda Miriam, Ana Fonseca, Susana Bastos
A peça Agamémnon foi apresentada pela primeira vez em Atenas no ano de 458 a.C. Foi escrita por Ésquilo (525-456 a.C.) e faz parte de uma trilogia intitulada Oresteia, a única trilogia completa que chegou até aos nossos dias, composta por três tragédias: Agamémnon, As Coéforas e As Euménides. A trilogia é inspirada nas histórias do regresso dos heróis que lutaram contra a cidade de Tróia.

Agamémnon teve que sacrificar a filha Ifigénia a Ártemis, no início da guerra, para que os exércitos gregos chefiados por ele pudessem chegar a Tróia. Segundo outras versões, Ifigénia não morreu durante o sacrifício, pois foi poupada pela deusa que a transformou numa sacerdotisa da cidade de Táuride. Atingida pela morte da filha, Clitemnestra jurou vingança. Tornou-se amante de Egisto, filho de Tiestes, e começou a conspirar contra o marido durante sua longa ausência.

Agamémnon regressa vitorioso após dez anos de guerra em Tróia, mas é imediatamente assassinado por Clitemnestra e Egisto, tal como Cassandra, princesa troiana, que recebera por cativa.

do Programa

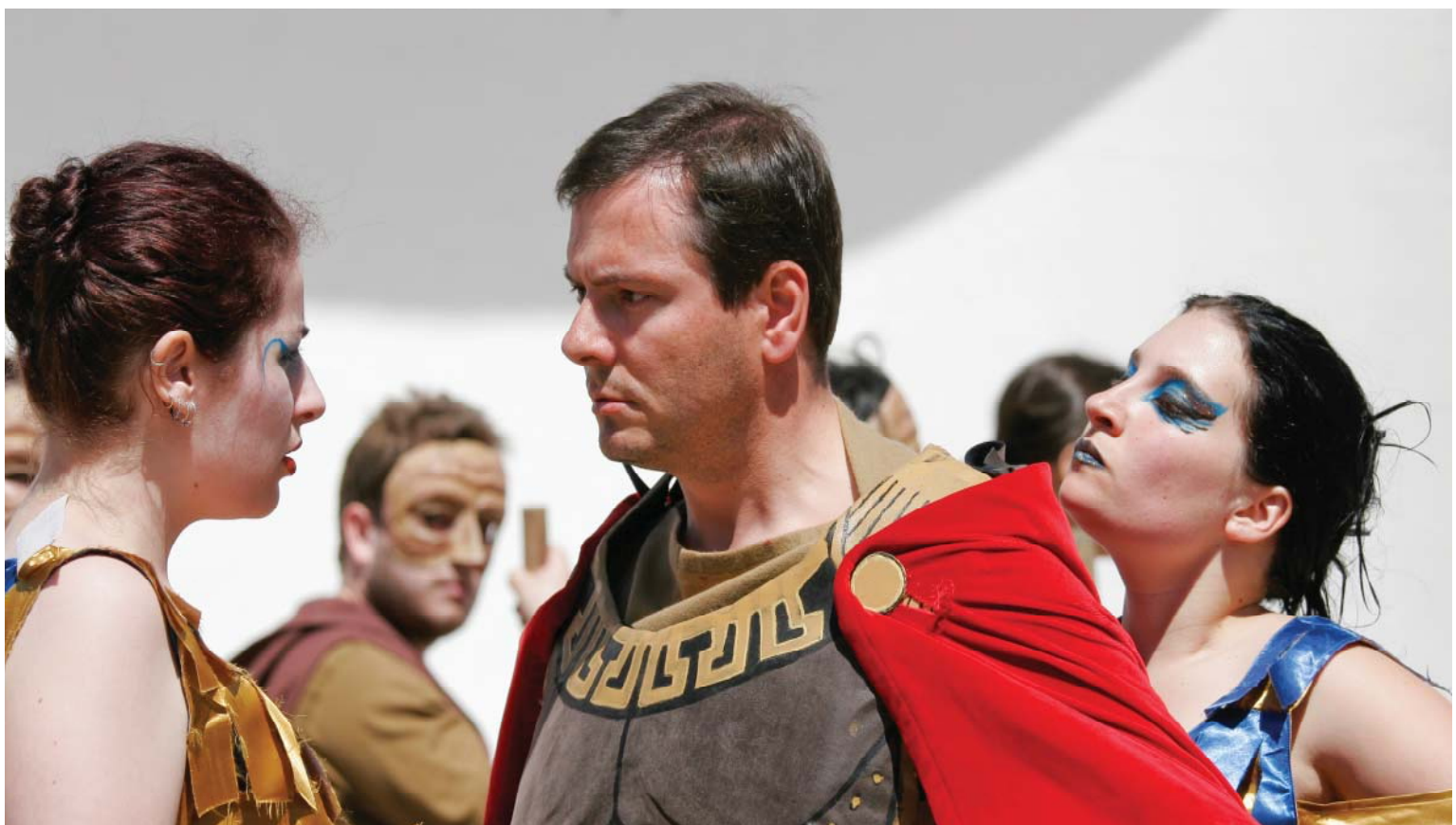



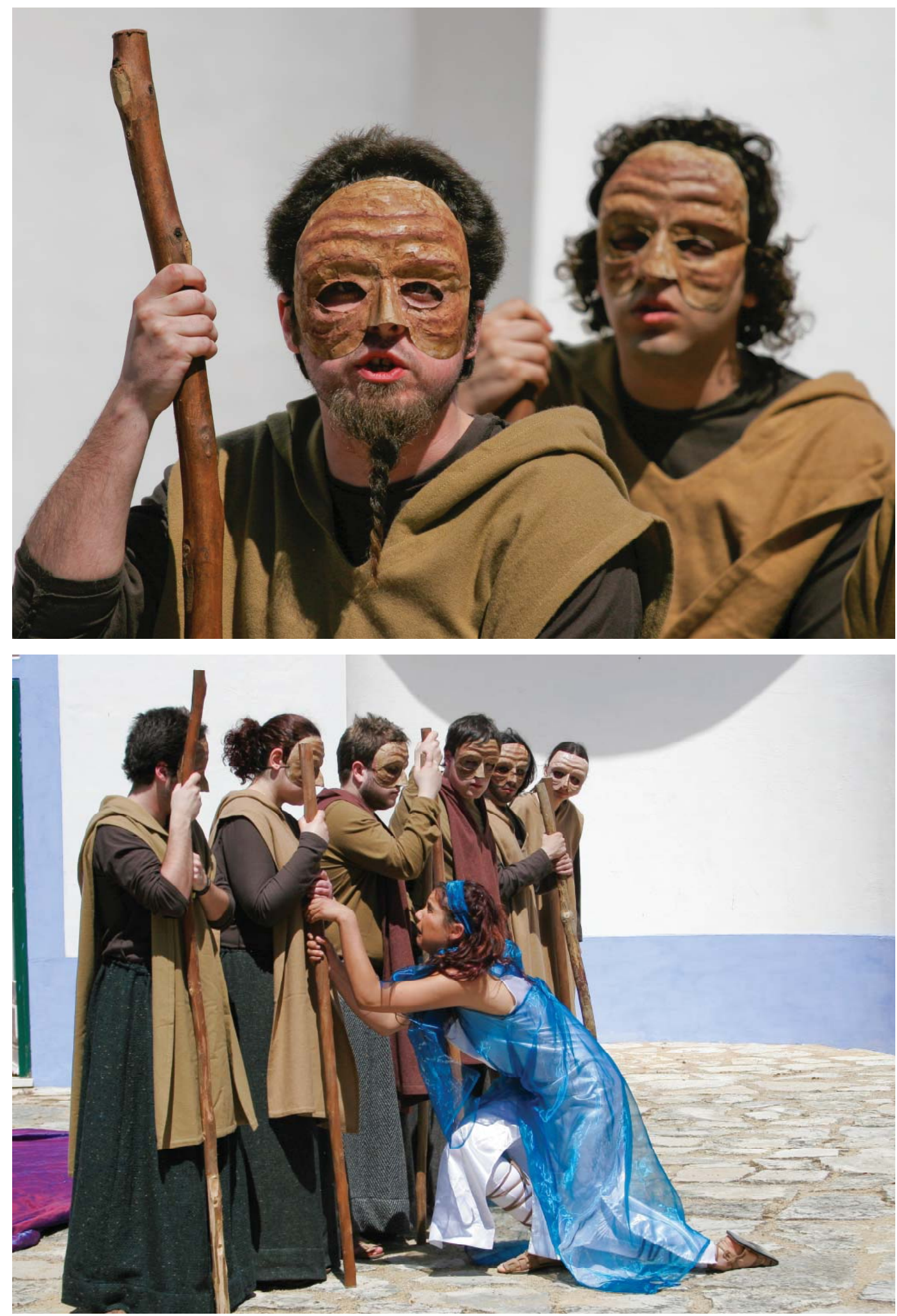

Agamémnon

de Ésquilo

Museu Arqueológico

de S. Miguel de Odrinhas

Fotos de José Antunes 


\section{A Comédia de Burros de Plauto}

Grupo Calatalifa de Madrid

\section{Encenação \\ Juan Bayona}

Figurinos

María José Abad, Marta Bengoa,

Ruth Patricia Sánchez

Cenografia

Mario Quiroga

Luz e som

Sonia García

\section{Elenco}

Irma García (Prólogo)

Patricia Martínez (Arauto)

Pablo Martínez, Javier Perdomo (Leónidas) Juan Bayona, Nacho Amado (Deméneto)

Carlos Martos, Daniel Robaler (Argiripo)

Yolanda Rino, Lucía Díaz (Cléereta)

Nini Jurado, Marta Guerra (Líbano)

Nacho Negreiro, Javier Perdomo (Mercador)

Irma García, Helena Rodríguez (Rapariga)

Susana Millán, Patricia Martínez (Filénia)

Javier Peláez, Javier Morillo (Diábolo)

Jorge Rodríguez, Benjamín Vacas (Parasita)

Esther Merino, Alba Alonso (Artémona)
A Asinaria de Plauto, estreada por volta do ano de 211 a.C., é uma das obras mais antigas de Plauto e possivelmente das que seguem com mais fidelidade a estrutura simples do modelo grego, no seu caso o Onagos de Demófilo.

Deve o seu título ao preço da venda de uns burros que, no enredo cómico, servirá para tirar de apuros Argiripo, o jovem enamorado que não tem dinheiro para pagar os favores da sua amada Filénia. Pela obra desfilam as personagens mais típicas da comédia plautina: os escravos espertalhões, a alcoviteira avarenta, o jovem enamorado, a meretriz de bom coração ou a intransigente matrona. Todas elas compõem, pela arte de Plauto e para nossa surpresa e alegria, uma comédia burlesca e nada maçadora que, numa sucessão de cenas cómicas, não tem outro objectivo além da pura diversão.

do Programa

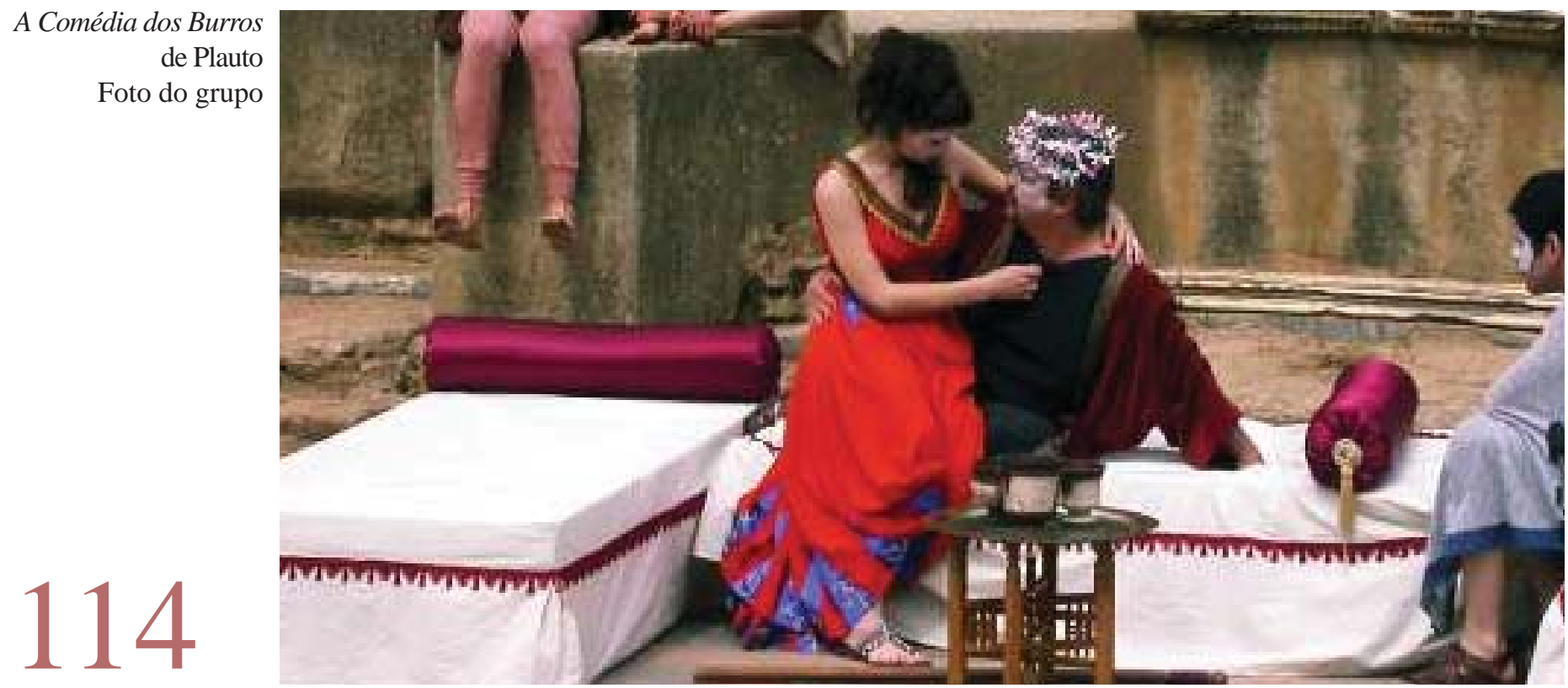




\section{Hécuba de Eurípides}

Grupo Hélios de Madrid

\section{Encenação}

José Luis Navarro

Gemma López Martínez

Coreografia e figurinos

Gemma López Martínez

\section{Confecção do guarda-roupa}

La Soleá, Maika Martínez

\section{Cenografia}

Tragacanto

Adereços

Jesús López Salinero

Caracterização

Alberto Andrés

\section{Luminotecnia}

Carlos Guitart

\section{Música}

Francisco Blanca, Pablo Cañones

\section{Elenco}

Gustavo Martín (Espectro de Polidoro)

Carmen María Ávila (Hécuba)

Cristina Sánchez (Políxena)

Oliver Plazas (Ulisses)

José Pons (Taltíbio)

Rosa Gómez (Serva)

Miguel Pato (Agamémnon)

Juan Diego Guerrero (Polimestor)

Cristian Ruíz

Arturo Fernández (Filhos de Polimestor)

Antonio Bardera, Antonio Martínez, Francisco

Blanca, Juan José Garcés (Hoplitas)

\section{Coro}

Gemma López Martínez (Corifeu), Rebeca Amez, Sara Andrés, Cintia Medina, Laura López, Laura Pascual, Eva Andrés, Virginia Oteros, María Álvarez, Marta Martín, Tamar Velasco, Erika Rayo, Vanesa Millán,

Melania Aguilera, Nadia Quintela,

Paloma Canseco, Andrea Cristóbal, María

Elisa Serrano, Alba García, Gina Patiño
Hécuba, assim como As Troianas, passa-se logo depois da Guerra de Tróia e coloca diante dos espectadores alguns dos aspectos mais negativos de qualquer guerra.

Após a queda de Tróia, os navios gregos chegam à Trácia. No acampamento Hécuba vê a filha Políxena ser sacrificada em honra de Aquiles, já morto, e logo depois depara-se com o cadáver do seu filho Polidoro, a quem julgava em segurança no palácio de Polimestor, seu genro. A rainha reúne forças e pede a Agamémnon, comandante dos gregos, uma oportunidade para castigar Polimestor. Então, com a ajuda das outras cativas troianas, cega o rei trácio e mata os seus dois filhos.

do Programa
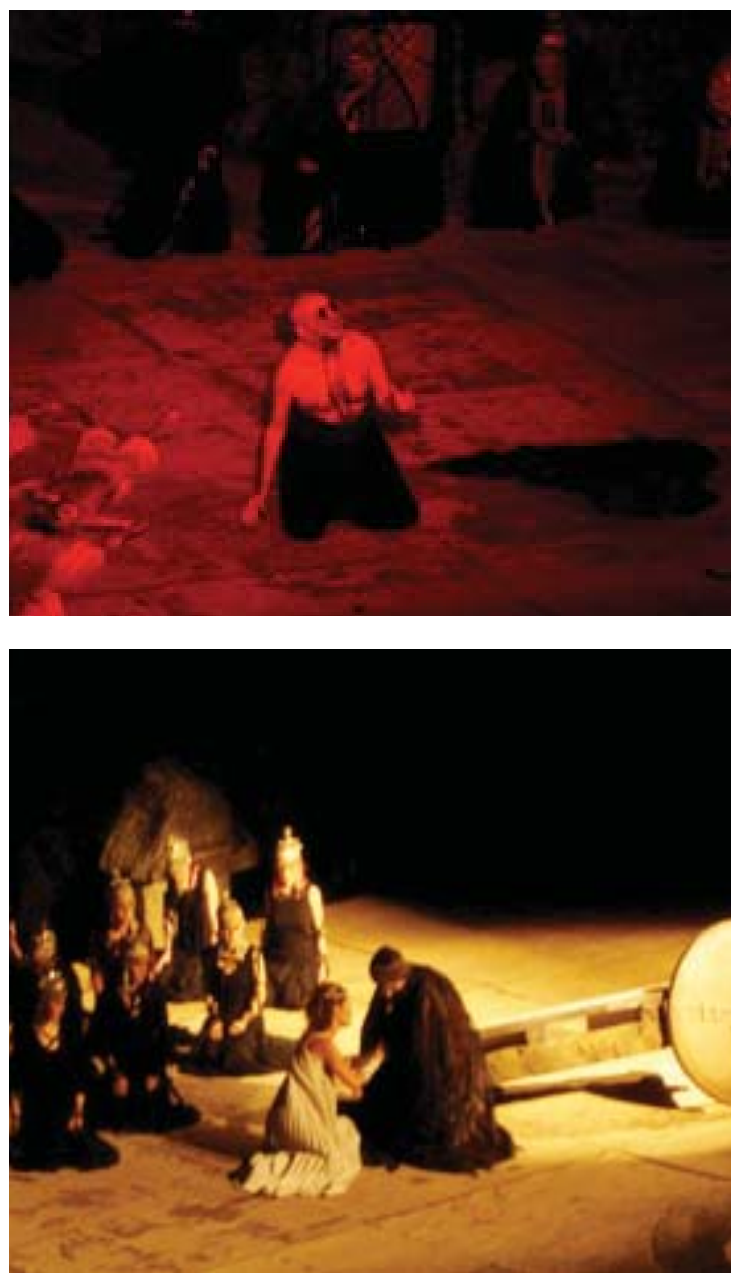

Hécuba de Eurípides Fotos do grupo

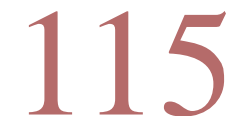




\section{O Gorgulho de Plauto}

Grupo Angelus do Colégio de S. Miguel (Fátima)

Tradução

Walter S. Medeiros

Encenação

Nuno Gertrudes e Rui Henriques

Cenografia

Sr. Armando, Carla Luís, Nídia Vieira, Carina Amado, Sandra Pereira, Tiffany Maurício,

Nuno Gertrudes, Rui Henriques

Figurinos

Lídia Pereira, Maria Helena Tomás,

Nuno Gertrudes

Caracterização

Tânia Pereira, Sandra Pereira,

Tiffany Maurício

Contra-regra

Milena Matos

Música

António Ribeiro, Valdo Marques

Selecção Musical

Nuno Gertrudes, Rui Henriques

Elenco

Carlos Ferraz (Soldado)

Sara Ferreira (Escrava)

Rui Henriques (Palinuro)

Joel Ferreira (Fédromo)

Carina Amado (Leena)

Mariana Cruz (Planésio)

Cláudia Santos, Nídia Vieira,

Diana Carreira (Cortesãs)

Márcio Menino (Cápadox)

Cidália Eusébio (Cozinheiro)

Andrea Guerreiro (Ajudante de Cozinheiro)

Nuno Gertrudes (Gorgulho)

Ana Guedes (Guarda-roupa)

João Oliveira (Lição)

Rui Parreira (Terapontígono)

João Palrinhas (Soldado - Comandante)

Rui Henriques (Soldado - Manicure)
O Gorgulho é uma típica comédia de reconhecimento, como outras que existem na obra plautina (Cistellaria, Poenulus ou Epidicus). Contudo, um dos pontos mais relevantes desta obra prende-se com a galeria notável de personagens-tipo que se encontram numa só comédia, algo de original em Plauto e na própria comédia greco-latina. Encontram-se aqui o escravo engenhoso, o enamorado, a velha ávida de vinho, a jovem enamorada, o alcoviteiro, o cozinheiro, o parasita, o onzeneiro e o soldado fanfarrão, cada um deles com as suas características tradicionais das peças plautinas.

do Programa

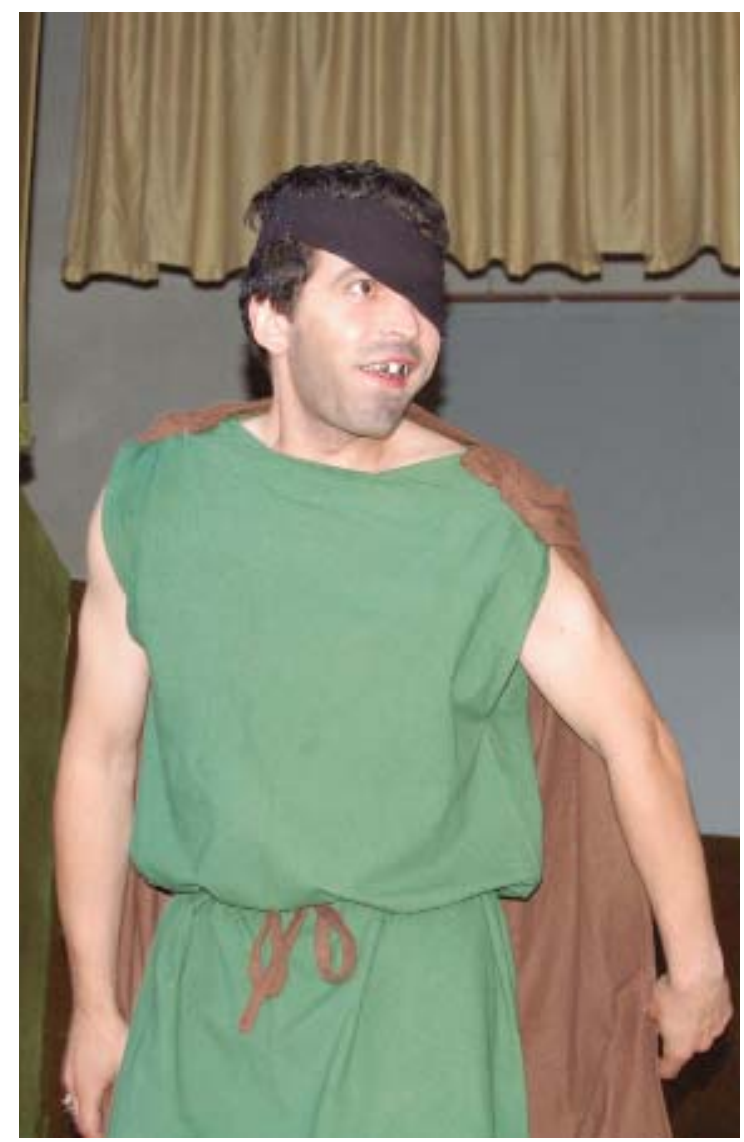



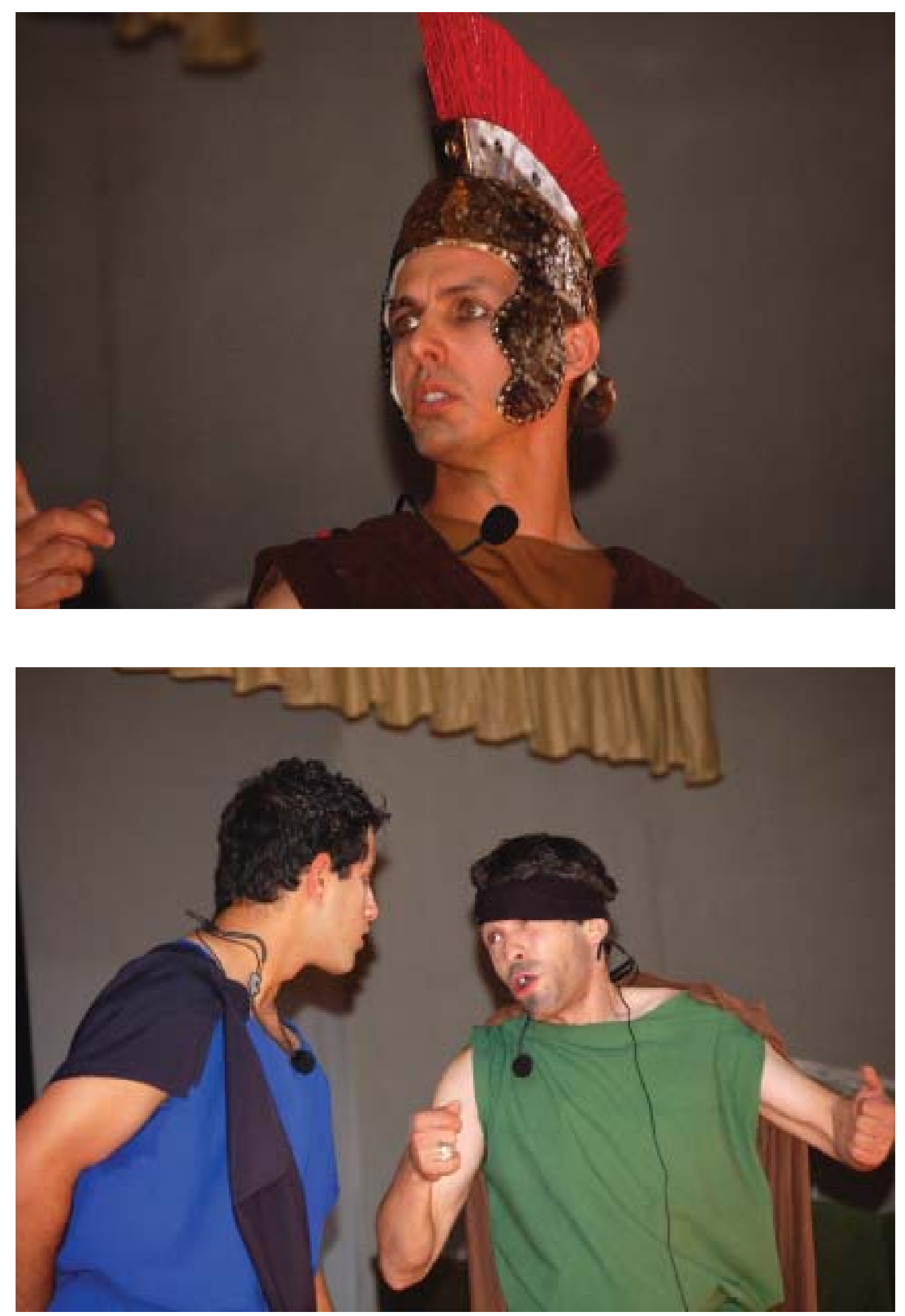

Gorgulho de Plauto

Fotos do grupo

117 


\section{$X$ FESTIVAL INTERNACIONAL DE TEATRO DE TEMA CLÁSSICO}

29 de Abril de 2008, 21.30 horas, Teatro Paulo Quintela da Faculdade de Letras de Coimbra As Vespas de Aristófanes, grupo Thíasos do IEC

7 de Maio de 2008, 21.30 horas, Auditório Mirita Casimiro (Viseu) Agamémnon de Ésquilo, grupo Thíasos do IEC

14 de Maio de 2008, 10.00 horas, Museu Arqueológico de S. Miguel de Odrinhas Ifigénia em Áulide de Eurípides, grupo de Teatro Clássico da Universidade de Alicante

14 de Maio de 2008, 15.30 horas, Museu Arqueológico de S. Miguel de Odrinhas As Vespas de Aristófanes, grupo Thíasos do IEC

15 de Maio de 2008, 21.30 horas, Páteo da Universidade de Coimbra Ifigénia em Áulide de Eurípides, grupo de Teatro Clássico da Universidade de Alicante

17 de Maio de 2008, 21.30 horas, Jardim Botânico (Coimbra) Agamémnon de Ésquilo, grupo Thíasos do IEC

18 de Maio de 2008, 21.00 horas, Biblioteca Joanina da Universidade de Coimbra Doze anos, doze quadros, grupo Canto e Drama do Conservatório de Música de Coimbra

24 de Maio de 2008, 21.30 horas, Conimbriga Doze anos, doze quadros, grupo Canto e Drama do Conservatório de Música de Coimbra

30 de Maio de 2008, 18.30 horas, Museu do Vinho (Anadia) As Vespas de Aristófanes, grupo Thíasos do IEC

7 de Junho de 2008, 21.30 horas, Conimbriga As Vespas de Aristófanes, grupo Thíasos do IEC

2 de Julho de 2008, 21.30 horas, Auditório Mirita Casimiro (Viseu) As Bacantes de Eurípides, grupo de Teatro Clássico da ESAD de Málaga

3 de Julho de 2008, 21.30 horas, Páteo da Universidade de Coimbra As Bacantes de Eurípides, grupo de Teatro Clássico da ESAD de Málaga

5 de Julho de 2008, 21.30 horas, Museu D. Diogo de Sousa (Braga) As Bacantes de Eurípides, grupo de Teatro Clássico da ESAD de Málaga

6 de Julho de 2008, 21.30 horas, Museu D. Diogo de Sousa (Braga) As Vespas de Aristófanes, grupo Thíasos do IEC

8 de Julho de 2008, 21.00 horas, Páteo da Universidade de Coimbra As Vespas de Aristófanes, grupo Thíasos do IEC 
10 de Julho de 2008, 21.00 horas, Castelo de Penela

La Guerre est douce, grupo Les Enfants de Nysa (Paris, E.S.R.A.)

11 de Julho de 2008, 21.30 horas, Conimbriga

La Guerre est douce, grupo Les Enfants de Nysa (Paris, E.S.R.A.)

13 de Julho de 2008, 18.00 horas, Auditório Municipal de Santiago da Guarda As Vespas de Aristófanes, grupo Thíasos do IEC

18 de Julho de 2008, 21.30 horas, Castelo de Penela

As Suplicantes de Eurípides, grupo Thíasos do IEC

19 de Julho de 2008, 21.30 horas, Parque das Tílias (Fundão)

As Vespas de Aristófanes, grupo Thíasos do IEC

20 de Julho de 2008, 21.30 horas, Quinta do Ervedal (Castelo Novo)

As Suplicantes de Eurípides, grupo Thíasos do IEC

Em 2008, o FESTEA comemorou a décima edição dos festivais, razão pela qual a organização fez um esforço de valorização do programa. No sentido de cumprir este desiderato, o X Festival Internacional de Teatro de Tema Clássico contemplou um conjunto de 22 iniciativas distintas (20 espectáculos de teatro e dois de música).

Uma das marcas do Festival é o forte carácter itinerante, pelo que as iniciativas decorreram em Coimbra, Conimbriga, Anadia, Sintra, Viseu e Braga, tendo este ano sido incluídos três novos espaços (Penela, Santiago da Guarda e Fundão), em obediência a um esforço continuado de descentralização. A organização julga que, com estes novos contactos, estabeleceu importantes parcerias para o futuro do Festival.

Houve igualmente um reforço na participação de grupos estrangeiros, neste ano em número de três: dois espanhóis - de Alicante e de Málaga - e um francês, criado especificamente para actuar no X Festival de Teatro de Tema Clássico, fruto da colaboração entre o FestEA e o Festival Européen de Latin et Grec (FELG) dirigido por Elisabeth Antébi. A produção deste último grupo foi de resto escrita e encenada em exclusivo para o Festival, pelo que a organização entendeu por bem editar o livro-bilhete da peça em versão bilingue, com isso pretendendo, ao mesmo tempo, chegar a novos públicos.

Delfim Ferreira Leão
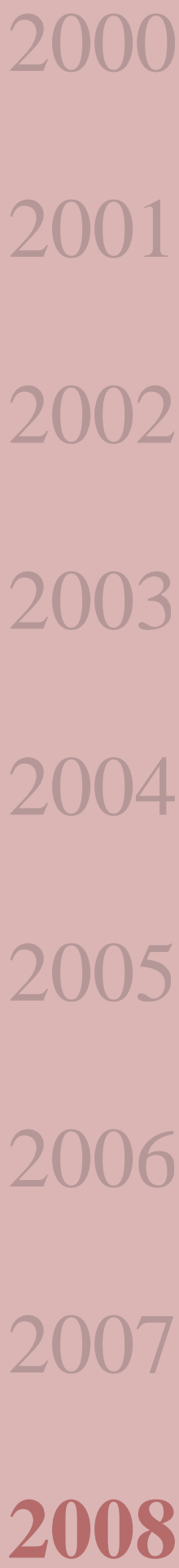

X Festival Internacional de Teatro de Tema Clássico

Na sua décima edição, a associação promotora Festea - Tema Clássico e a Associação Cultural Thíasos apresentam o Festival Internacional de Teatro de Tema Clássico. De 29 de Abril a 20 de Julho o programa prevê espectáculos em Coimbra, Viseu, Braga, Conimbriga, Anadia, S. Miguel de Odrinhas, Miranda do Corvo, Penela, Santiago da Guarda e Fundão.

\section{Paula Alexandra Almeida}

Assinalando a sua décima edição, o Festival Internacional de Teatro de Tema Clássico contempla este ano um conjunto de 22 iniciativas distintas - 20 espectáculos de teatro e dois de música-, para além de umas Jornadas de Turismo e Teatro Clássico, durante as quais será lan çado o volume comemorativo dos 10 anos, que pretende também funcionar como arquivo das actividades desenvolvidas.

Promovido pela associação Festea - Tema Clássico e Associação Cultural Thíasos, uma das marcas do festival é, desde sempre, o seu forte carácter itinerante. Este ano não é excep ção e o programa propõe iniciativas em Coimbra, Conimbriga, Miranda do Corvo, Anadia, Sintra, Viseu e Braga, espaços jà tradicionais ao longo das edições anteriores, e arrisca três novo espaços - Penela, Santiago da Guarda e Fundão - , em obediência a um esforço continua do de descentralização.

São seis as peças incluída na edição 2008 do Festival Internacional de Teatro de Tem Clássico - As Vespas de Aristófanes, Agamémnon de Ésquilo e As Suplicantes de Eurípides, pelo Grupo Thíasos do IEC, Ifigénia em Áulide de Eurípides pelo Grupo de Teatro Clásico da Universidade de Alicante, As Bacantes de Eurípides pelo Grup de Teatro Clássico ESAD (Escuela Superior de Arte Dramá-
(24 de Abril de 2008)

Texto de Paula Almeida

\section{Associacão Cultural Thíasos:}

\section{há 17 anos a divulgaar os clássicos}

Em Novembro de 1991, alguns dos assistentes que agora integram o corpo de docentes do Instituto de Estudos Clássicos, então colegas de curso, encenavam, na cerimónia comemorativa da sagração da Sé Velha de Coimbra, um texto original, da autoria de Delfim Leão, intitulado "Sé Velha - Pedras Vivas". Essa primeira iniciativa, inteiramente preparada por alunos, iria conhecer um importante avanço em Março de 1992, altura em que discentes do $4^{\circ}$ ano de licenciatura organizaram um colóquio subordinado ao tema "O Amor desde a Antiguidade Clássica".

Entre as várias actividades propostas, foi possível assistir à representação de parte do Soldado Fanfarrão plautino, e foi a partir desse momento que se colocou, verdadeiramente, a possibilidade de criar um grupo de teatro de tema clássico.

No entanto, somente em 1996 é que se retomou o projecto de teatro, com a rodagem, em Conímbriga, da versão vídeo da comédia de Aristófanes "Mulheres no Parlamento", sob a direcção de Delfim Leão.

No seguimento destas actividades, e por proposta do então director do Instituto, José Ribeiro Ferreira, decidiu oficializar-se a existência do grupo e aprofundar a formação teatral dos seus membros. Como consequência da nova orgânica, o Thíasos dramatizou - Epídico de Plauto, encenado por Paulo Sérgio Ferreira, que foi visto por cerca de oito mil espectadores, em Portugal e Espanha, durante o biénio 1999/2000.

A 5 de Julho de 2000, o grupo celebrou a escritura pública dos seus estatutos, tendo adoptado a denominação de "Associação Cultural Thíasos" (ico), de Málaga, e "La Guerre est jolie" pelo Grupo Les Enfants de Nysa (Paris, E.S.R.A.), uma peça baseada em textos antigo sobre a Paz, num espectácul montado no quadro de colaboração europeia entre o Festea o Festival Européen Latin Grec, pela parte francesa.

Do programa constam ainda, como também já vem sendo habitual, dois espectáculos lírico pelo grupo Canto e Drama do Conservatório de Música de Coimbra

Teatro de tema clássico desperta interesse renovado do público

Ao longo dos últimos anos, e semelhança da iniciativa do Thiasos, muitos têm sido os festivas de teatro de tema clássico que se vêm realizando. Com um sucesso de certa forma inesperado, estas representações, n sua maioria levadas a cabo po grupos amadores, tiveram o mé rito, entre outros naturalmente, de renovar o interesse quer pelo teatro, quer por parte de cama das mais jovens quer adultos, de despertar a atracção pela cultura clássica de uma form geral, e particularmente por muitos dos seus textos, nomeadamente os de teatro.

Para tal contribuiu muito também a acção do Thíasos, que ao longo destes anos, de todas as peças por si representadas, o por outros apresentadas nos festivais, sempre editou um livro, que originalmente serve de bilhete, com o texto em causa. Um forma simpática e despreocupada de divulgar alguns dos texto mais significativos da cultur clássica, até então desconhecidos do grande público. E val realmente a pena passear po estes textos escritos há séculos atrás mas, alguns deles, de plena actualidade.

As Vespas de Aristófane foram apresentadas pela primeir vez em 422 a.C., no contexto da Guerra do Peloponeso. Na peça, Aristófanes procura satirizar mau funcionamento das instituições democráticas, centrando-se, sobretudo, nos tribunais, que apresenta, na pessoa de Filócleo e do próprio coro, como uma obsessão dos cidadãos mais envelhecidos, que só ai encontram a sua fonte de rendimento. Recriando-se em cena um tribunal doméstico, onde arguido e acusado são dois cães - porém representativos de dois políticos da ribalta, nesse tempo bem conhecidos - , torna-se a cada passo manifesta a corrupção que domina as instituições juridicas do tempo.

Já Agamémnon de Ésquilo, que viveu entre 525 e 456 a.C., é a única parte da trilogia Oresteia - as outras são Coéforas As Euménides - a chegar completa aos nossos dias. Na tragédia em causa, o pano de fundo o regresso dos heróis gregos que combateram em Tróia. Tambén de Eurípides são Ifigénia em Aulide, As Suplicantes e As Bacantes. Ifigénia em Áulide foi representada pela primeira vez en 405 a.C., nas Dionísias Urbana de Atenas. Fazia parte de uma trilogia, juntamente com As Ba cantes e Alcmeon em Corinto, recebeu o primeiro prémio no concurso de tragédias. A tragédia baseia-se num dos episódio mais famosos do Ciclo Troiano, no qual Agamémnon, rei de $\mathrm{Mi}-$ cenas, comandante das forcas gregas que se preparam para atacar Tróia, é compelido a sacrificar sua filha Ifigénia para que deusa Artemis cesse a longa calmaria que impede o zarpar das naus aportadas em Áulide.

Já As Suplicantes, representadas no contexto da Guerra do Peloponeso, entre 431 e 404 a.C., resulta numa acutilante sofrida reflexão sobre as consequências da guerra, de todos os tempos. E As Bacantes é um peça repleta de contradições que, à margem da sua encenação, provoca uma série de dúvidas. Trata-se da última das obra conservadas de Eurípides, representada já depois da sua morte. em que o antagonismo entre tradição e os costumes do homem racional, na figura de Penteu, e a rebelião contra esta tradição, na figura de um deu Diónisos muito ambíguo, marca o contraponto da tragédia.

\section{PROGRAMA}

Dia 29 de Abril de 2008 ( $3^{\circ}$ feira), 21 h30, Coimbra, Teatro Paulo Quintela (FLUC) Grupo Thiasos do IEC, As Vespas do

Dia 4 de Maio de 2008, 16h, Miranda do Corvo [A confirmar] - Grupo Thiasos do IEC, As Vespas de Aristófanes

Dia 7 de Maio de 2008 ( $4^{4}$ feira), $21 \mathrm{~h} 30$, Viseu. Grupo Thissos do IEC, Aga. mémnon de Ésquilo

Dia 14 de Maio de 2008 (4 $4^{2}$ feira), $10 \mathrm{ho0}$ Dank - Grupo de Teatro Clásico de Euripides

Dia 14 de Maio de 2008 (4' feira), 15h30, Odrinhas - Grupo Thíasos do IEC, Ves.

Dia 15 de Maio de 2008 (5' feira), $21 \mathrm{~h} 30$ Coimbra (Páteo da UC). Grupo de Tea tro Clasico (Univ. de Alicante), Ifigenna em Aulide de Euripides

Dia 17 de Maio de 2008 (Sábado), 21h30, Coimbra (Sta. Clara-a-Velha) - Grupo Thiasos do IEC, Agamémnon de És. quilo

Dia 18 de Maio de 2008 (Domingo) 21h00, Coimbra (Sta. Clara-a.Velha). Espectáculo lírico do grupo Canto Drama (Conservatório de Música de Coimbra)

Dia 24 de Maio de 2008 (Sábado) 21h30, Conimbriga - Espectáculo lirico do gr po Canto e Drama (Conservatorio do Música de Coimbra)

Dia 30 de Maio de 2008 ( $6^{2}$ feira), $21 \mathrm{~h} 30$ Anadia (Museu do Vinho) - Grupo Dia 07 de Junho de 2008 (Sábado), 211h30, Conimbriga - Grupo Thiasos

Dia 2 de Julho de 2008 ( $4^{\circ}$ feira), 21 h30, Viseu - Grupo de Teatro Clássico ESAD Malaga (Escuela Superior de Arte Dra mático), As Bacantes de Euripides

Dia 3 de Julho de 2008 ( $5^{a}$ feira), $21 \mathrm{~h} 30$, Coimbra (Páteo da UC) - Grupo de Tea tro Clássico ESAD - Málaga (Escuela Superior de Arte Dramático), As Bacantes de Euripides

Dia 5 de Julho de 2008 (Sábado), 21h30, Braga - Grupo de Teatro Clássico ESAD - Málaga (Escuela Superior de Arte Dra mático), As Bacantes de Euripides

Dia 6 de Julho de 2008 (Domingo), As 30 , Braga - Grupo Thisos do IEC, As Vespas de Aristófanes

Dia 8 de Julho de 2008 ( $3^{\circ}$ feira), $21 \mathrm{~h}$ Dia 10 de Julho de 2008 ( $5^{5}$ feira) Coim bra (Santa-Clara-a-Velha) - Grupo Les (Paris, E.S.R.A.), L Guerre est jolie 
Espectáculo hoje às $21 \mathrm{~h} 30$

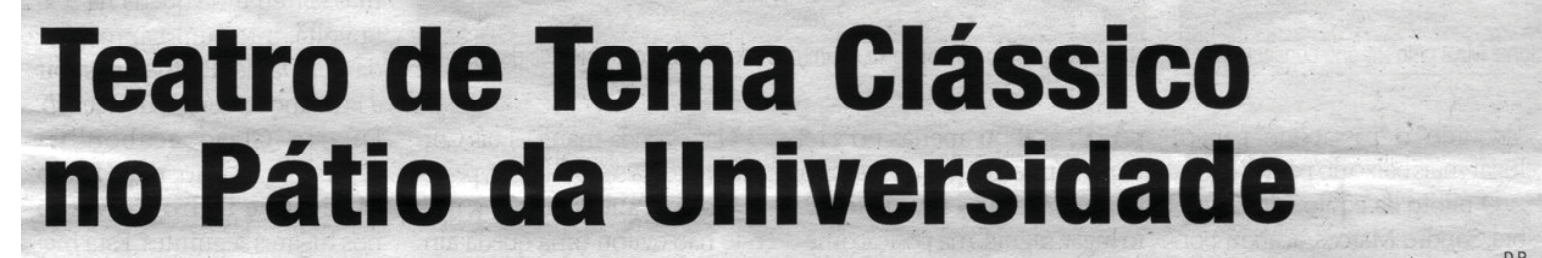

Diário de Coimbra

(15 de Maio de 2008)

O X Festival Internacional de Teatro de Tema Clássico prossegue hoje. O espectáculo "Ifigénia em Áulide", de Eurípdes, pelo Grupo de Teatro Clássico da Universidad de Alicante, está marcado para as 2Ih3o, no Pátio da Universidade de Coimbra (Via Latina)

Em paico, o grupo espanhol apresentará uma peça que foi representada pela primeira vez em 405 a.C., nas Dionísias Urbanas de Atenas.

"Ifigénia em Áulide" «fazia parte de uma trilogia, juntamente com As Bacantes e Alcmeon em Corinto (tragédia perdida) e recebeu o primeiro prémio no concurso de tragédias. Eurípides havia morrido alguns meses antes c "Eurípides o Jovem", filho (ou sobrinho) do poeta, foi o responsável pela apresentação da trilogiau, refere a organização do espectáculo.

«A tragédia baseia-se num dos episódios mais famosos do Ciclo Troiano. Agamémnon, rei de Micenas, comandante das forças gregas que se preparam para atacar Tróia, é compelido a sacrificar sua filha Ifigénia para que a deusa Ártemis cesse a longa calmaria que impede o zarpar das naus aportadas em Áulide. A inesperada chegada de Clitemnestra em companhia da filha e a intervenção de

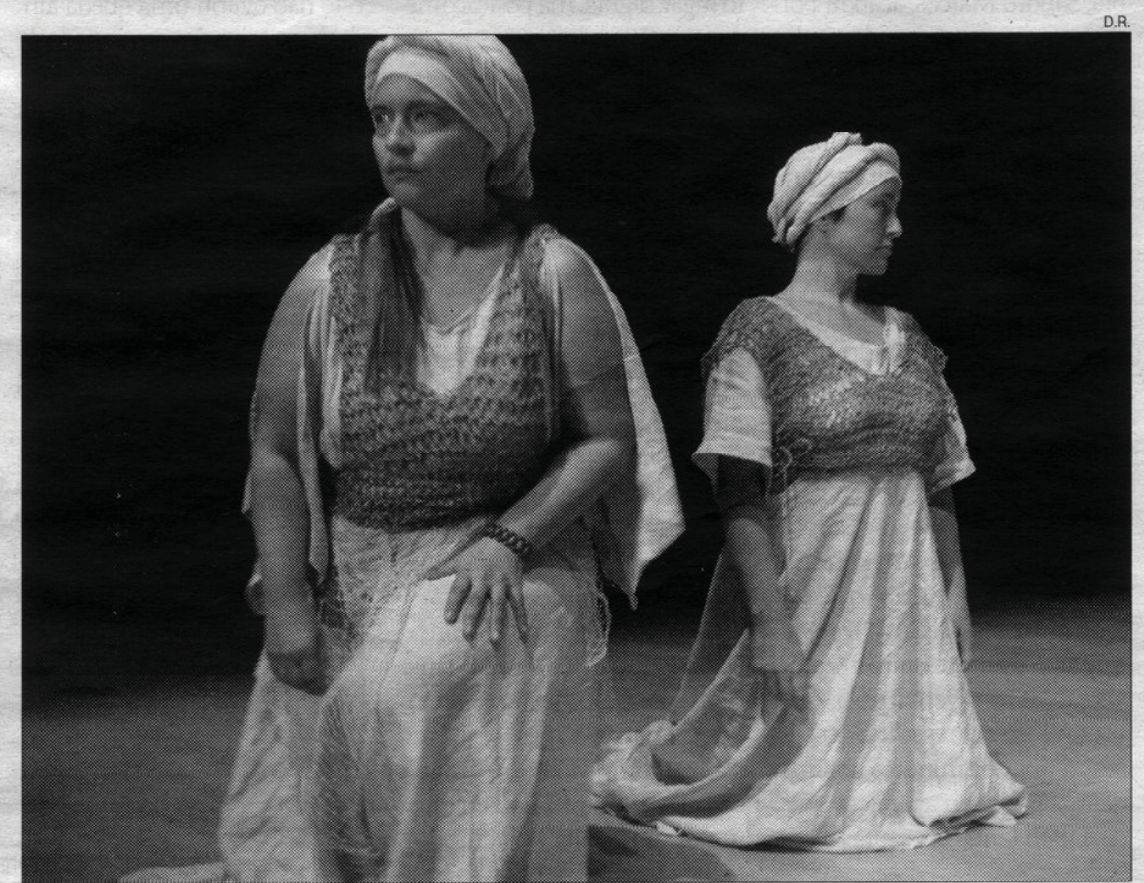

"Ifigénia em Aulide", de Eurípdes, pelo Grupo de Teatro Clássico da Universidad de Alicante

Aquiles, alheio à trama, complicam os seus planos».

"Ifigénia em Áulide" tem tradução e adaptação de María Paz López, encenação e dramaturgia de Charo Amador e coloca em palco Enrique Piera (Agamémnon), Encarna Segara (Ancião), Fernando Garcia (Menelau), Minguel Ángel López (Mensageiro), Loles Moreno (Clitemnestra), Ariana
Martínez (Ifigénia), Francisca López (Ama), Miguel Ángel Bravo (Aquiles), Roberto Sparano (Calcas). Coreutas: Irene Marcelo (Corifeu), Paola García, María José Alpañés. Bailarinas: Laura Martínez, Vanessa Yago, Laura Buil, Elisabeth Nicolás, Ana Sánchez, Gracia Urraca. Instrumentistas: Noelia Junquera (arpa) e Miriam Aracil (oboé). O espectáculo tem entrada livre, tal como os que se seguem no festival, sábado às 2Ih30 no Jardim Botânico de Coimbra, com o Grupo Thíasos do Instituto de Estudos Clássicos (Faculdade de Letras) a representar "Agamémnon" de Ésquilo, e domingo, às 2 r hoo, na Biblioteca Joanina, "Doze Anos, Doze Quadros", espectáculo lírico do grupo Canto e Drama (do Conservatório de Música de Coimbra). 


\section{As Vespas de Aristófanes}

Grupo Thíasos do IEC

\section{Encenação e tradução \\ Carlos de Jesus}

\section{Figurinos}

Carla Braz, Carlos de Jesus,

Luísa de Nazaré Ferreira, Maria Valente

\section{Composição musical}

José Luís Brandão

Selecção musical

Carlos A. Martins de Jesus

\section{Sonoplastia}

Carla Cerqueira

Luminotecnia

Rodolfo Lopes, Carlos Santos

Cenografia

José Luís Brandão, Carla Braz

\section{Elenco}

José Luís Brandão (Filócleon)

Carlos A. Martins de Jesus (Bdelícleon)

Artur Magalhães (Xântias)

Susana Bastos (Sósias e Mírtia)

Carla Correia (Dárdanis)

Ângela Leão, Carla Correia (Cão Cidateneu)

Bruno Fernandes (Corifeu)

\section{Coro}

Mariana Matias, Ândrea Seiça,

Nelson Henrique, Carla Rosa,

Nilce Carvalho, Susana Rosa, Amélia Álvaro de Campos, Miguel Sena

\section{Corinho}

Ália Rodrigues, Carla Braz,

Verónica Fachada, Stella Quandt

Apresentada pela primeira vez em 422 a.C., no contexto da Guerra do Peloponeso, e obra de um Aristófanes já firmemente posicionado no panorama cómico ateniense, a comédia Vespas procura testar as diversas iguarias de cómico, entre a tradição e a novidade, e tem de ser entendida como reacção ao desaire que constituiu, para o seu autor, o não reconhecimento do mérito da comédia apresentada no ano anterior, Nuvens.

No comum cenário do exterior de uma casa de Atenas, Aristófanes procura satirizar o mau funcionamento das instituições democráticas, centrando-se, sobretudo, nos tribunais, que apresenta, na pessoa de Filócleon e do próprio Coro, como uma obsessão dos cidadãos mais envelhecidos, que só aí encontram a sua fonte de rendimento. Recriando-se em cena um tribunal doméstico, onde arguido e acusado são dois cães - porém representativos de dois políticos da ribalta, nesse tempo bem conhecidos -, torna-se a cada passo manifesta a corrupção que domina as instituições jurídicas do tempo.

do Programa

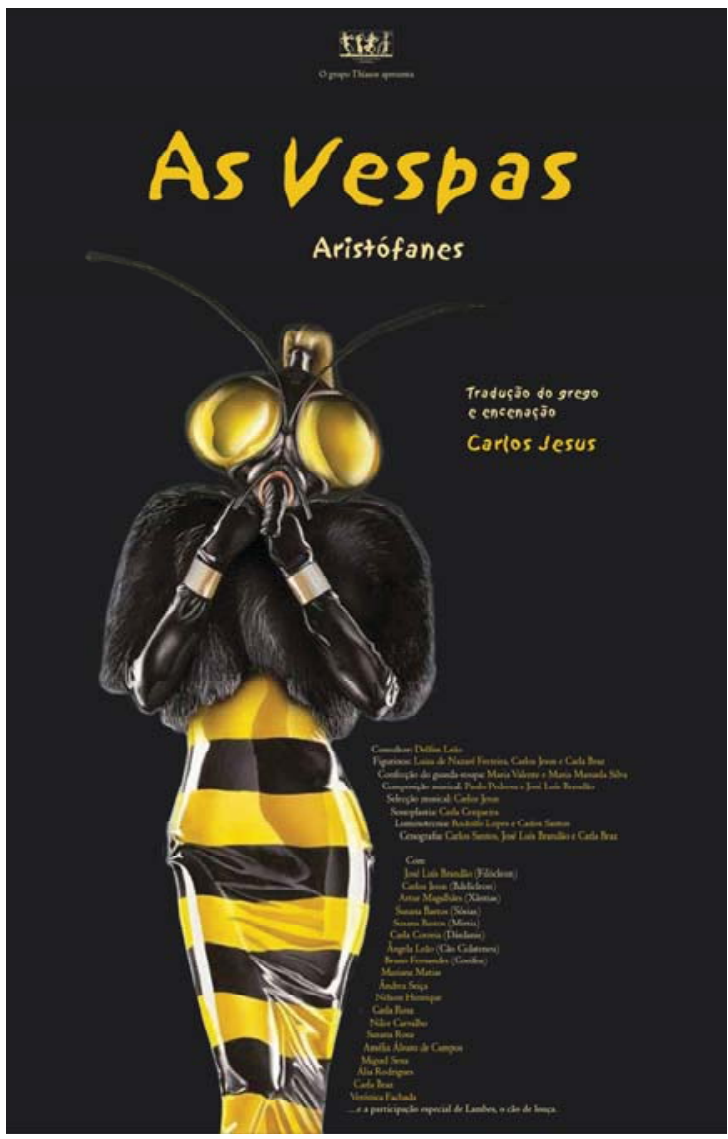



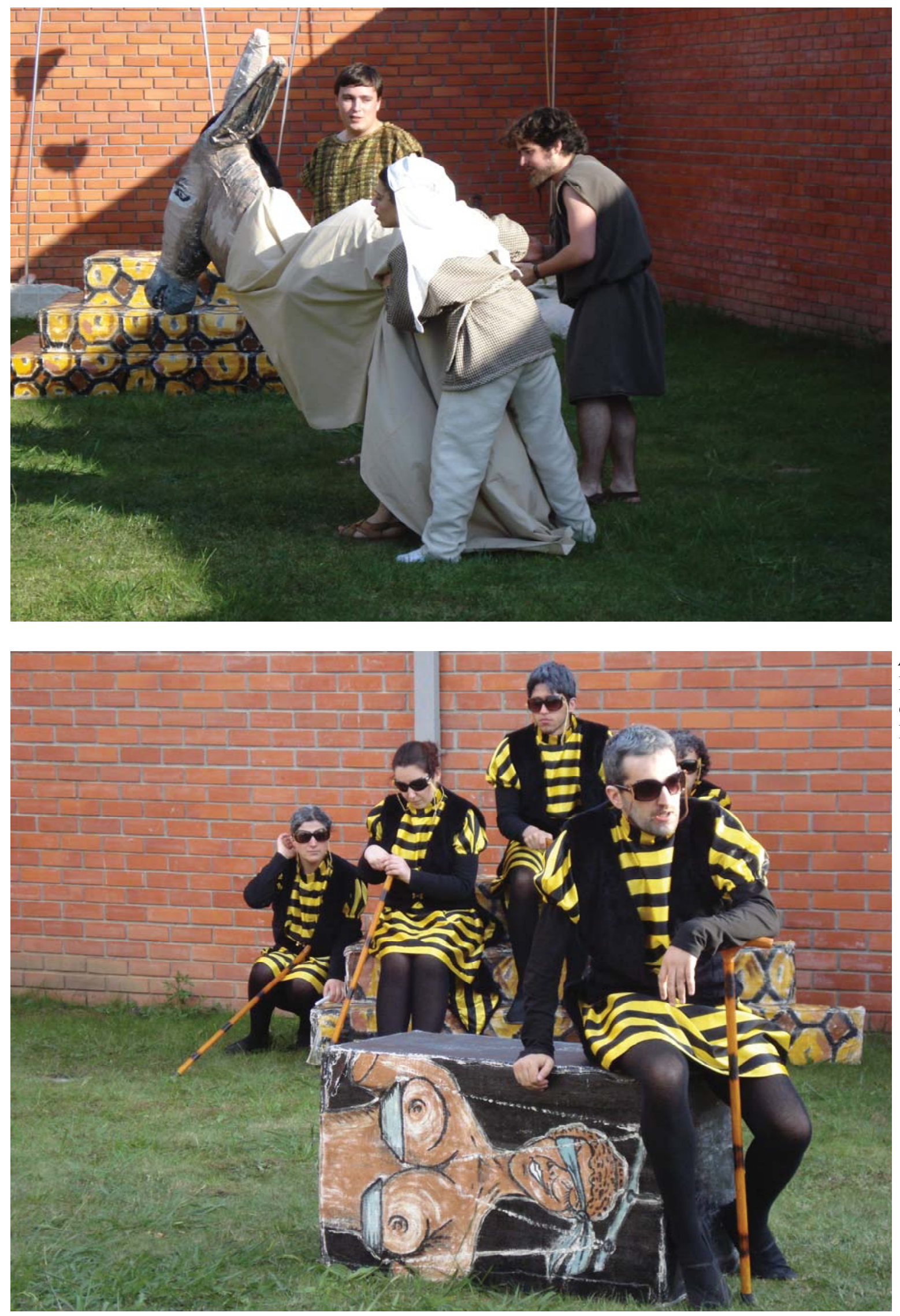

As Vespas de Aristófanes Museu do Vinho de Anadia

Fotos de Rodolfo Lopes 


\section{Ifigénia em Áulide de Eurípides}

Grupo de Teatro Clássico

da Universidade de Alicante

\section{Encenação e dramaturgia \\ Charo Amador \\ Composição musical \\ José María Vives Ramiro \\ Coreografia \\ María Obdulia Díaz \\ Cenografia}

Enrique Piera, Talleres Piñero

Luminotecnia

Ximo Hernández

Figurinos

Charo Amador, Loles Moreno

Concepção do guarda-roupa

Isabel López, María Martínez,

Loles Moreno

Maquilhagem

Yolanda Escrich

Elenco

Enrique Piera (Agamémnon)

Encarna Segara (Ancião)

Fernando García (Menelau)

Minguel Ángel López (Mensageiro)

Loles Moreno (Clitemnestra)

Ariana Martínez (Ifigénia)

Francisca López (Ama)

Miguel Ángel Bravo (Aquiles)

Roberto Sparano (Calcas)

\section{Coro}

Irene Marcelo (Corifeu),

Paola García, María José Alpañés

\section{Bailarinas}

Laura Martínez, Vanessa Yago, Laura Buil,

Elisabeth Nicolás, Ana Sánchez,

Gracia Urraca

\section{Instrumentistas}

Noelia Junquera (harpa)

Miriam Aracil (oboé)
A Ifigénia em Áulide foi representada pela primeira vez em 405 a.C., nas Dionísias Urbanas de Atenas. Fazia parte de uma trilogia, juntamente com As Bacantes e Alcméon em Corinto (tragédia perdida), e recebeu o primeiro prémio no concurso de tragédias. Eurípides havia morrido alguns meses antes e "Eurípides o Jovem”, filho (ou sobrinho) do poeta, foi o responsável pela apresentação da trilogia.

A tragédia baseia-se num dos episódios mais famosos do ciclo troiano. Agamémnon, rei de Micenas, comandante das forças gregas que se preparam para atacar Tróia, é compelido a sacrificar sua filha Ifigénia para que a deusa Ártemis cesse a longa calmaria que impede o zarpar das naus aportadas em Áulide. A inesperada chegada de Clitemnestra em companhia da filha e a intervenção de Aquiles, alheio à trama, complicam os seus planos.

do Programa

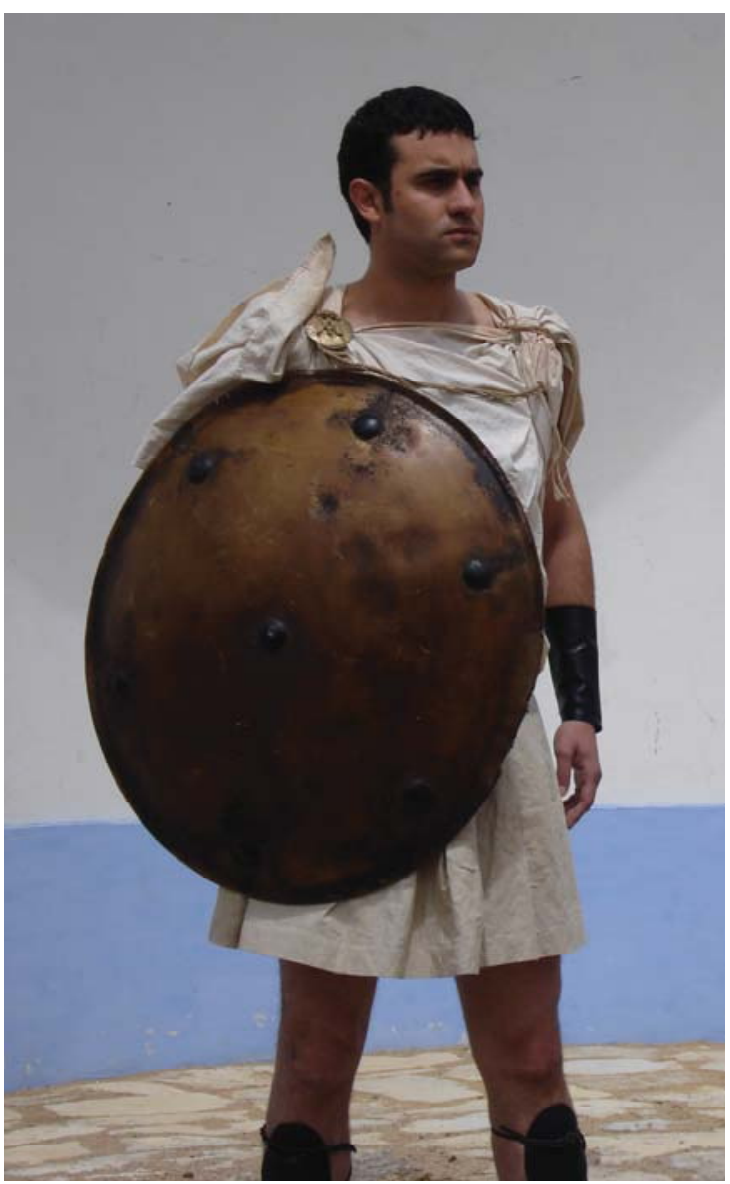




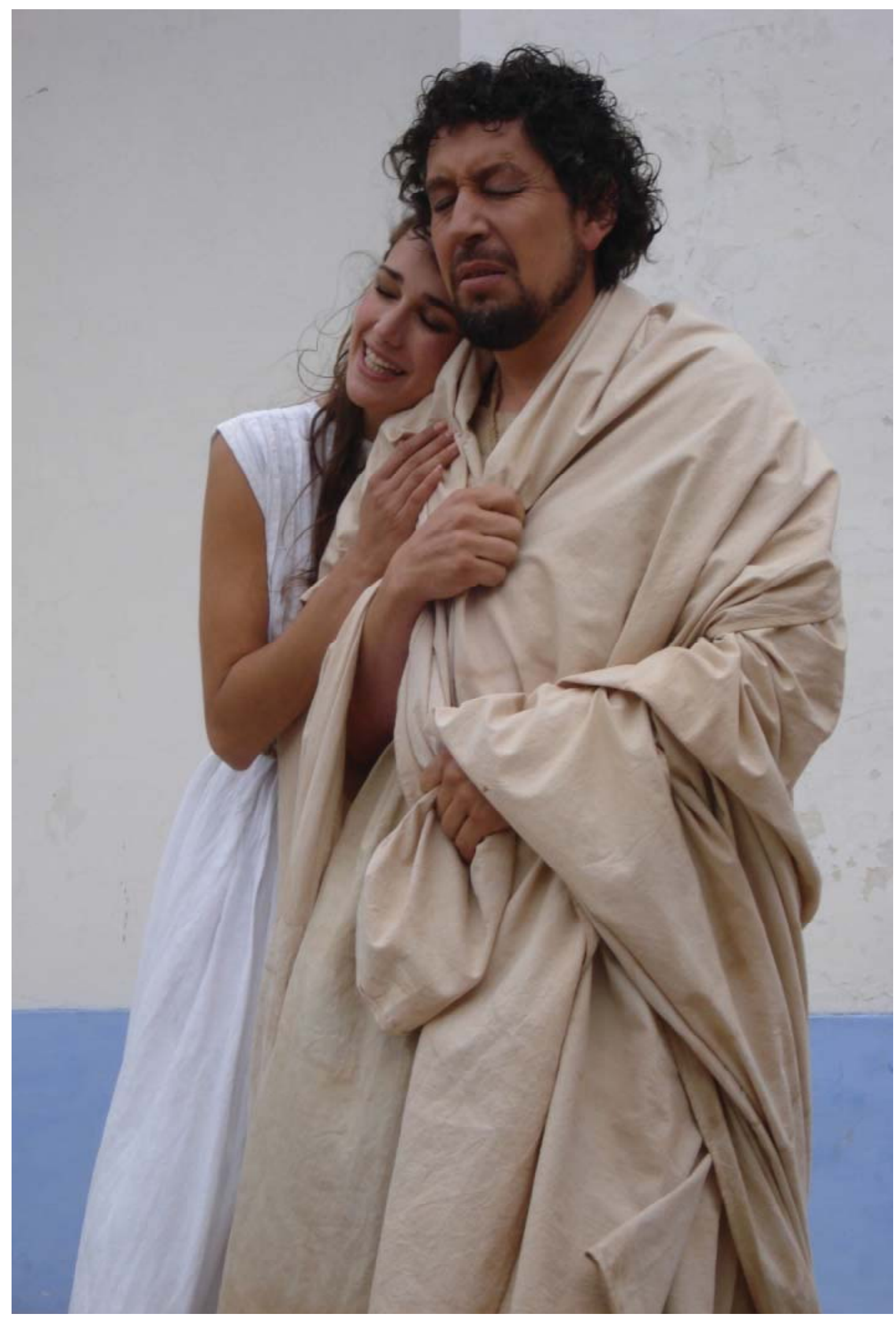




\section{As Bacantes de Eurípides}

Escuela Superior de Arte Dramático

(ESAD) de Málaga

\author{
Adaptação e encenação \\ Andreu \\ Cenografia \\ Pilar Jiménez \\ Desenho de luzes \\ Eun Kyung Kang \\ Figurinos \\ Andreu \\ Música \\ José Manuel Padilla \\ Canção de Tebas \\ Juan Carlos Vilaseca \\ Assistente de coreografia \\ Rebeca Ríos \\ Confecção do guarda-roupa \\ Pilar Jiménez, Andreu \\ Realização de cenografia \\ Héctor Morales \\ Director de cena \\ Emma Muñoz \\ Chefe da equipa técnica \\ Emilio Martínez
}

Assistente de direcção

Emma Muñoz

Sonoplastia

Germán Benítez Leiva

Elenco

Chico García (Penteu)

Luis Alcedo (Diónisos)

Raquel Pérez (Agave)

Fran Martín (Cadmo)

Emilio Martínez (Capitão)

Frank Vélez (Pastor)

Lucas Ortiz (Tirésias)

Fran Millán (Soldado)

May Melero (Autónoe)

Irina Baños (Ino)

$$
\text { Coro }
$$

Irina Baños, Tamara Gómez,

Laura Molina, Carmen Melero,

Emilia Moreno, Noelia Navarro,

Marta Pavón, Amanda Ríos, Rebeca Ríos,

Beatriz Saavedra, Marina Sánchez,

Vanesa Serrano

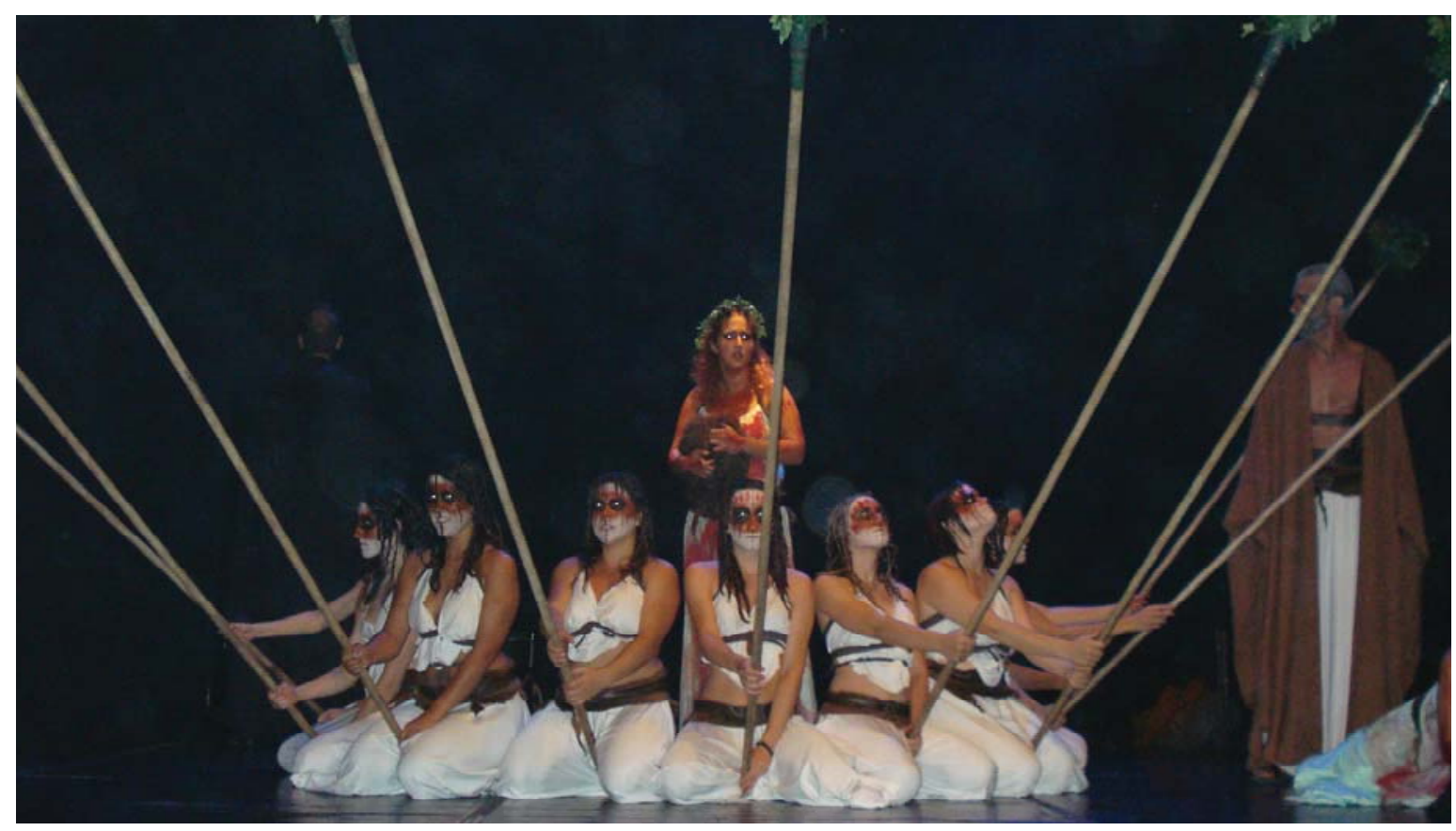


Estamos perante uma peça repleta de contradições que, à margem da sua encenação, provoca uma série de dúvidas. Trata-se da última das obras conservadas de Eurípides, representada já depois da sua morte, que, nas palavras de Julio Pallí Bonet, “pode considerar-se um canto de cisne.” O antagonismo entre a tradição e os costumes do homem racional, na figura de Penteu, e a rebelião contra esta tradição, na figura de um deus Diónisos muito ambíguo, marca o contraponto da tragédia.

Os acentuados contrastes do texto agudizam-se com a metamorfose de Diónisos, de carácter divino, e o transformismo de Penteu, numa tentativa artificial de mudar a realidade, mas, de qualquer modo, tudo está ao serviço da representação, com o objectivo de difundir a mensagem, não do deus, mas do próprio autor, por via da máscara teatral, ou seja, do metateatro como técnica dramática.
O tema e o argumento pertencem ao culto dionisíaco e dizem respeito à introdução destes ritos na Grécia. O deus Diónisos chega a Tebas para introduzir o seu culto, mas depara-se com a oposição do rei Penteu, defensor das tradições antigas. Diónisos deixa-se prender, mas logo se escapa de forma prodigiosa, e convence o rei a, vestido de mulher, ir ao monte espiar as bacantes, entre as quais se encontra Agave, a sua mãe. Descoberto pelas mulheres, Penteu é desmembrado por elas e a sua cabeça é levada pela mãe, como troféu, até à cidade.

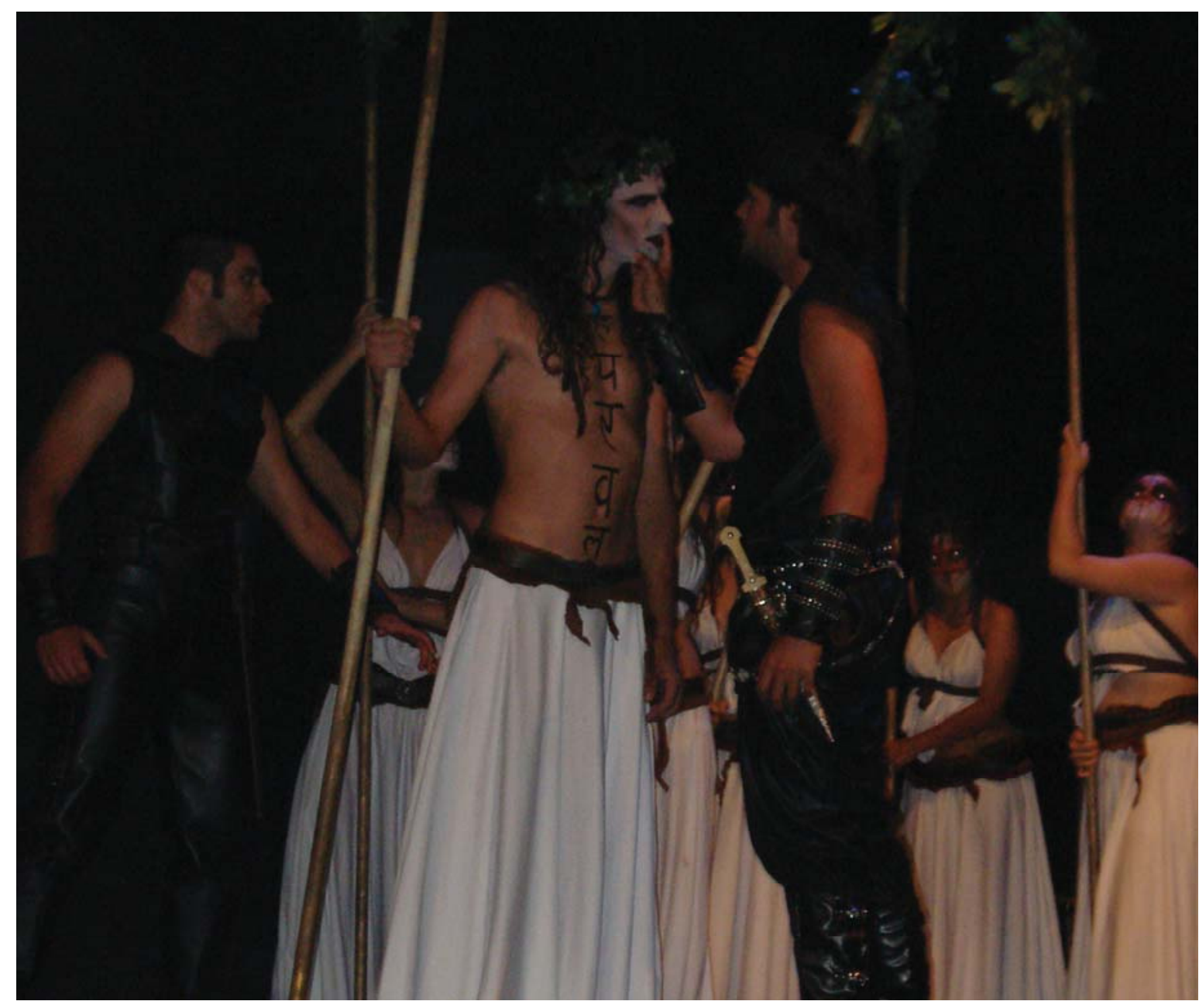

As Bacantes de Eurípides Teatro Mirita Casimiro (Viseu)

Fotos de Carlos Jesus

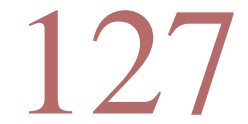




\section{Como é doce a guerra... de Chantal Collion}

Les Enfants de Nysa da E.S.R.A. de Paris

\author{
Encenação \\ Tiphaine Renard \\ Iluminação \\ Kevin Lafargue \\ Som \\ Jean Amanieu
}

Assistente de encenação

Benjamin Guicheteau

Cenários

Yohan Chemmoul, Julia Delprat

Música

Niels Prayer

Coreografia

Kiyoshi Yamamoto

Guarda-roupa e maquilhagem

Palmyre Roigt, Joséphine Mathis, Dounia Khellaf

\section{Fotografia}

Aurélie Larnicol

Realização de vídeo

Michaël Ayach, Kevin Lafargue

Grafismo

Julia Diérickx-Brax

Elenco

Damien Sartran (Caronte)

Michaël Ayach (Alastor)

Guillaume Sorel (Erasmo)

Alias Issa (Trigeu, Ésquilo)

Clément Paillette (Hermes)

Joséphine Mathis (Paz)

Aurélie Larnicol (Lisístrata, Corifeu)

Dounia Khellaf (Calonice)

Lucie Stern (Mírrina)

Chloé Désiré (Lâmpito)

Palmyre Roigt (Moça, Andrómaca)

David Martinez (Príamo)

Kevin Lafargue (Arquíloco)

Jean Amanieu (Saint-Exupéry)

Maïa (Criança da Paz)
Como é doce a guerra... é uma obra ficcional, concebida no âmbito do Festival Européen de Latin et Grec (FELG), para o Festival Internacional de Tema Clássico, a realizar em Portugal. A única directriz que recebi foi a de criar uma montagem de textos gregos e latinos para apresentar em Coimbra um espectáculo que facilmente se inscrevesse no tema geral do FELG de 2008: "Os exploradores do mundo: o turismo, a guerra, a ciência”.

O nome de Erasmo (1467-1536) todos o conhecemos, mas a sua obra, considerada demasiado austera e digna somente da curiosidade dos historiadores, tem sido negligenciada ao longo dos tempos. Quando citamos um título de Erasmo, referimo-nos normalmente à sua obra $O$ Elogio da Loucura. Uma vez cognominado "Príncipe dos Humanistas”, colocámo-lo num pedestal, esquecendo o ser apaixonado que, apesar "da pequena estatura, adoentada e delicada" e, mais tarde, "enfraquecida pela idade, pela fadiga de viagens esgotantes e de constantes esforços intelectuais”, trabalhou com afinco determinado no renascimento da cultura greco-latina, sobretudo depois da sua fascinante descoberta da língua grega, quando contava já mais de trinta anos.

Este combate de toda uma vida é o suficiente para justificar a imagem que criámos de Erasmo como o herói do dia, neste festival consagrado à promoção da língua latina e grega. E mais: o cosmopolitismo da personagem que se dizia "cidadão do mundo" e "compatriota de todos", destinava-o naturalmente a honrar com a sua presença, póstuma e dramatizada, os dois festivais europeus. O seu pacifismo resoluto e intransigente, pode ajudar a aclarar a nossa própria reflexão sobre o tema da exploração do mundo pela guerra. Aqui está como Erasmo se tornou herói de Como é doce a guerra... e a sua obra o fio condutor desta fantasia dramática que, desta forma, se impõe claramente para além de um simples jogo literário, como um verdadeiro manifesto humanista. 
Embora se trate de um texto lúdico, Como é doce a guerra... não deixa de estar recheado de intenções didácticas e pode ser abordado como um jogo de pistas, onde cada espectador deverá descobrir o autor que se esconde por detrás de cada réplica. Concedo ao leitor algumas indicações no início de cada quadro em pequenos textos-miniatura que não fazem parte do corpus dramático propriamente dito, mas que serão projectados em vídeo durante a representação, com o intuito de guiar os espectadores. Proponho a todos aqueles que desejam saber mais para nos encontrarmos no posfácio... mas só depois de terem visto o espectáculo ou lido a peça!

Chantal Collion Tradução do francês de Ana Seiça

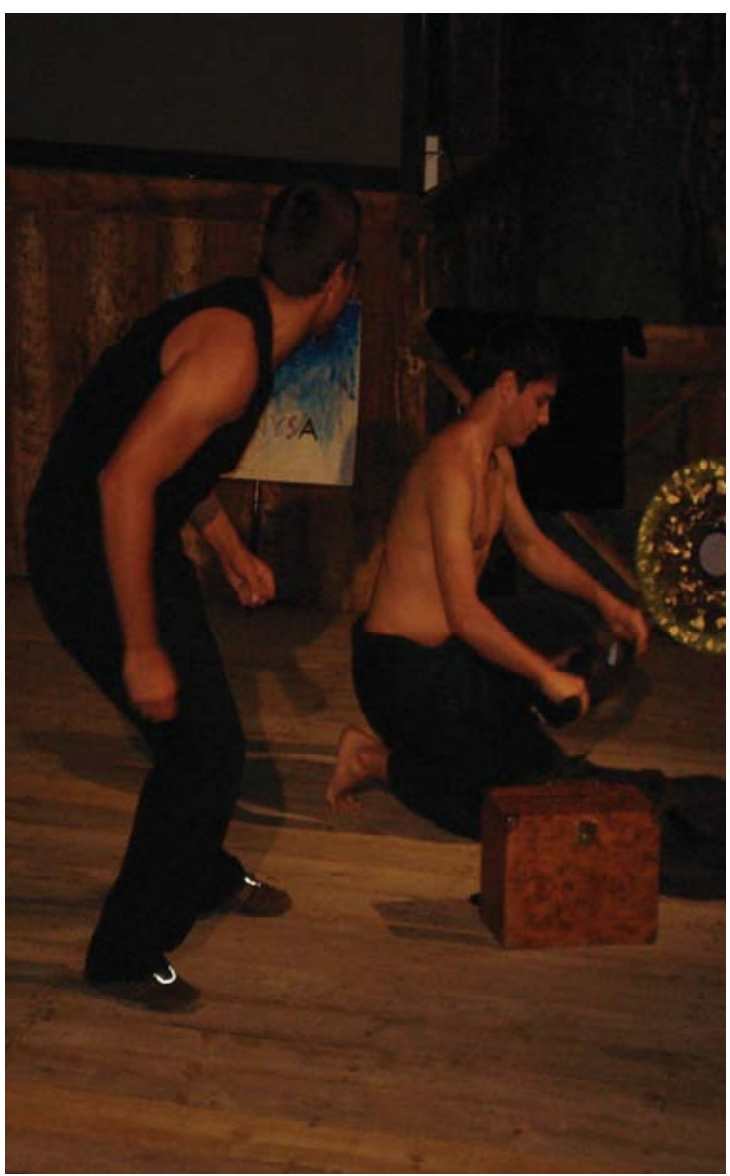

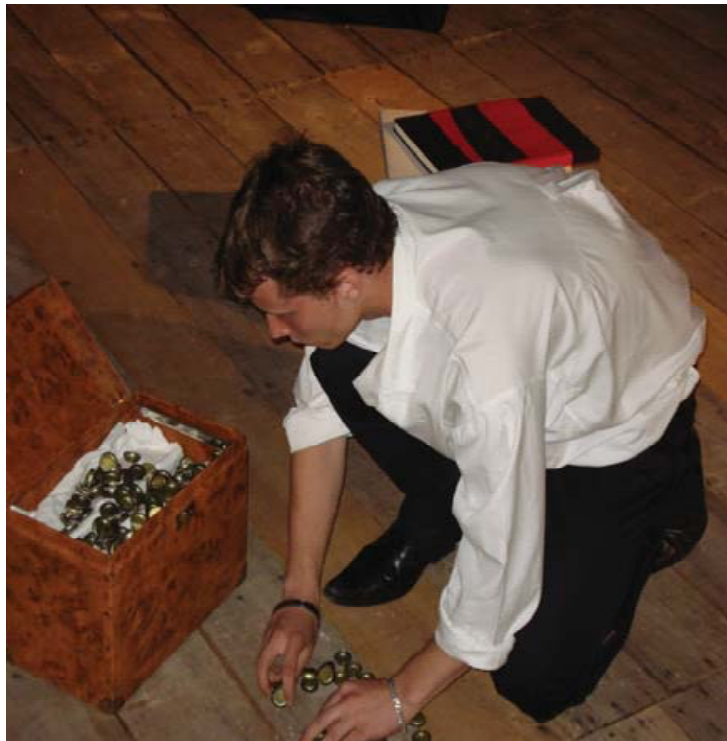

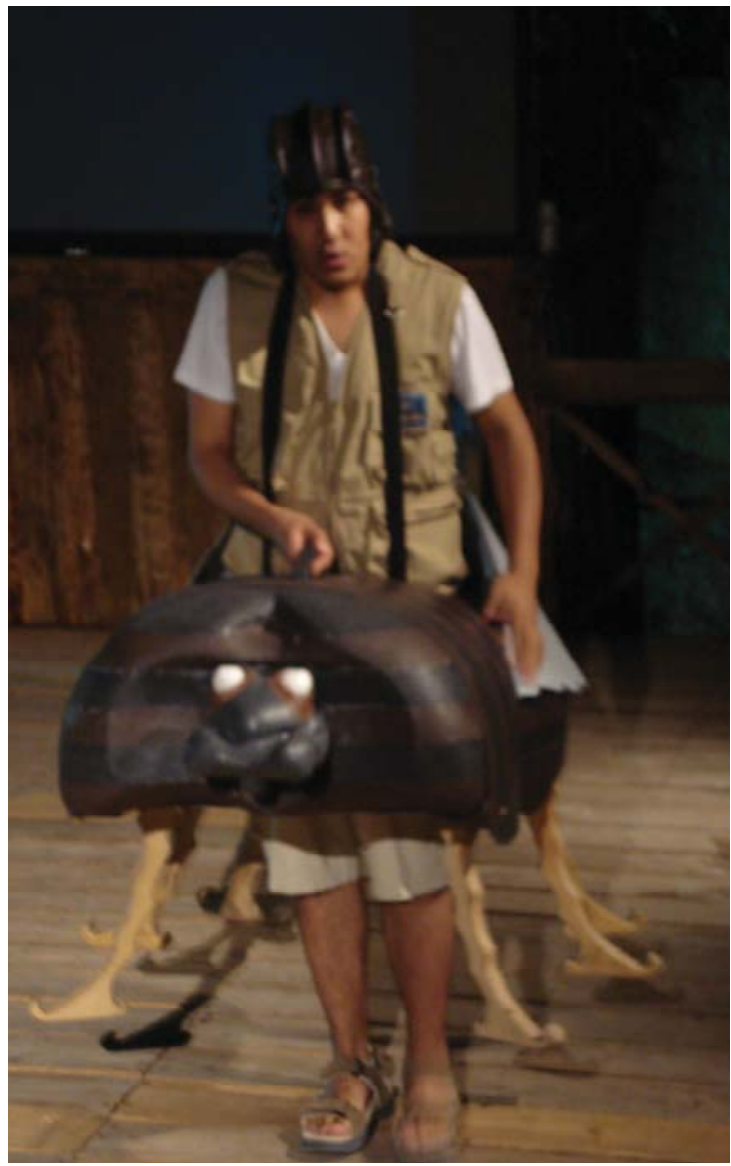

Como é doce a guerra... de Chantal Collion Castelo de Penela Fotos de Carlos Jesus

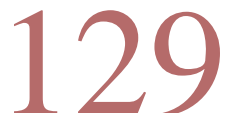




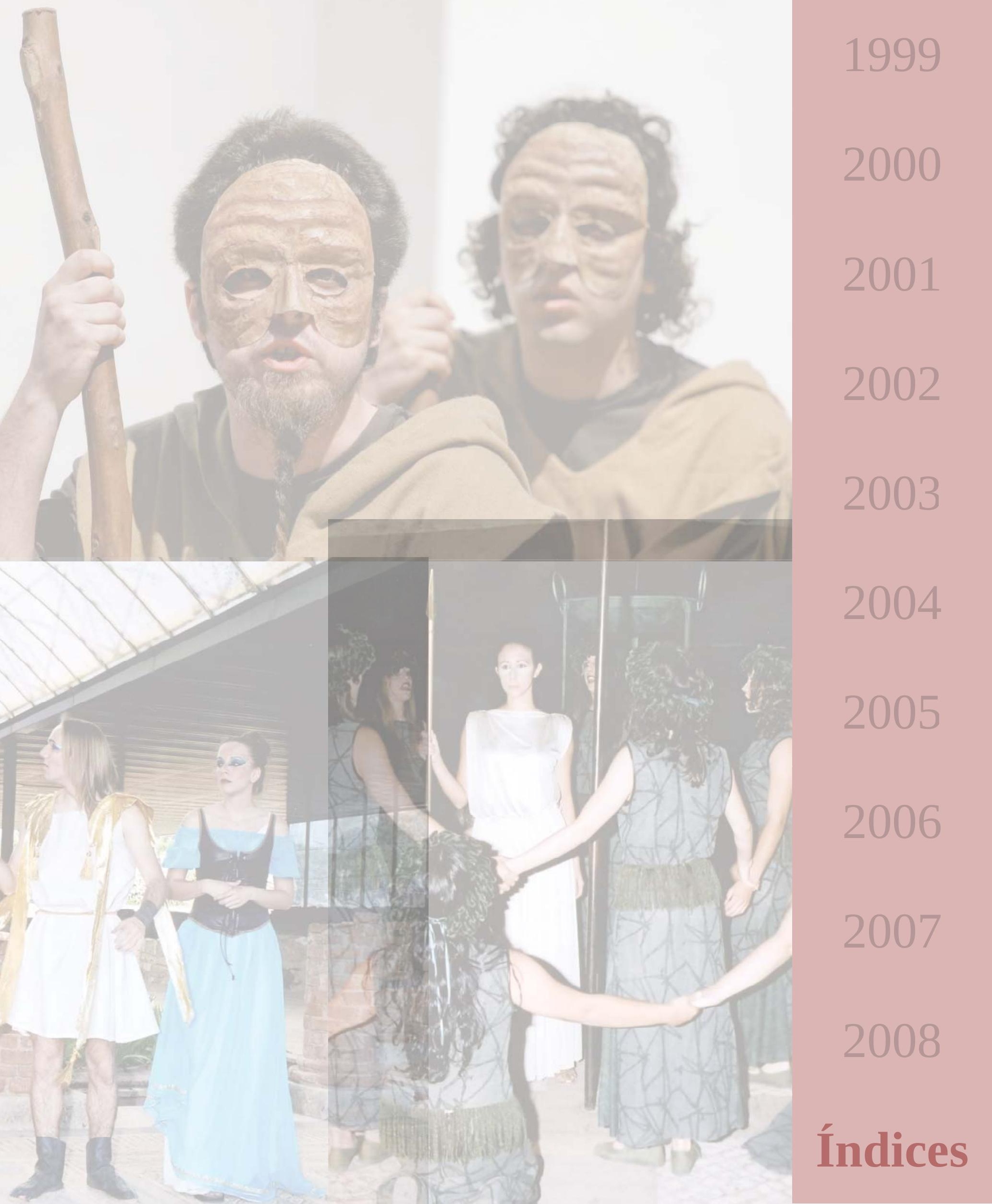




\section{Os livros-bilhete}

Ao longo dos dez anos da existência dos Festivais de Teatro de Tema Clássico, a organização editou, de forma sistemática, os textos das peças levadas à cena pelos diversos grupos, nacionais e estrangeiros, que passaram pelos palcos portugueses.

Sempre com a preocupação de publicar traduções realizadas directamente da língua original, da responsabilidade de especialistas na área e/ou no autor em causa, a colecção conta, até ao final de 2009, com trinta e oito volumes editados, entre tragédias e comédias, gregas e latinas, mas também outras dramatizações apresentadas no âmbito do Festival.

É primeiro objectivo destes volumes de bolso, de qualidade assegurada, a divulgação dos textos clássicos. No âmbito do Festival Escolar, as obras costumam ser enviadas antecipadamente aos grupos escolares que vêm assistir às representações, sendo que é também usual a sua distribuição pelo público imediatamente antes da performance teatral.

Os volumes, quando disponíveis em stock, podem ser adquiridos no Instituto de Estudos Clássicos (Faculdade de Letras da Universidade de Coimbra, Largo da Porta Férrea, 3004-530 Coimbra).

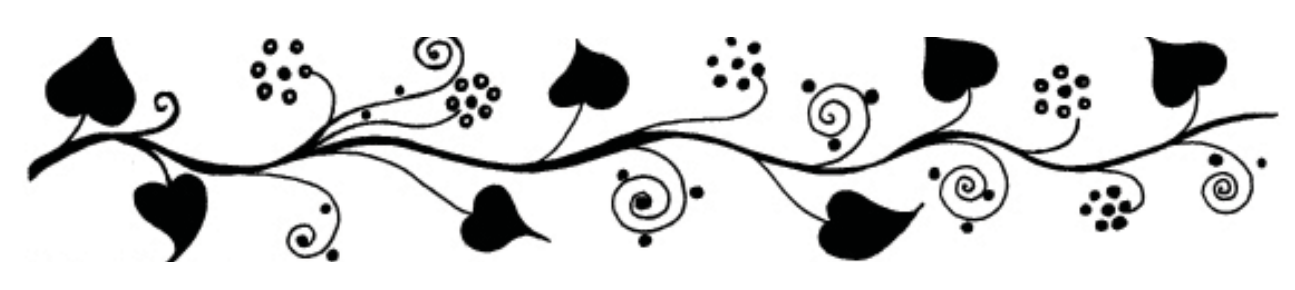




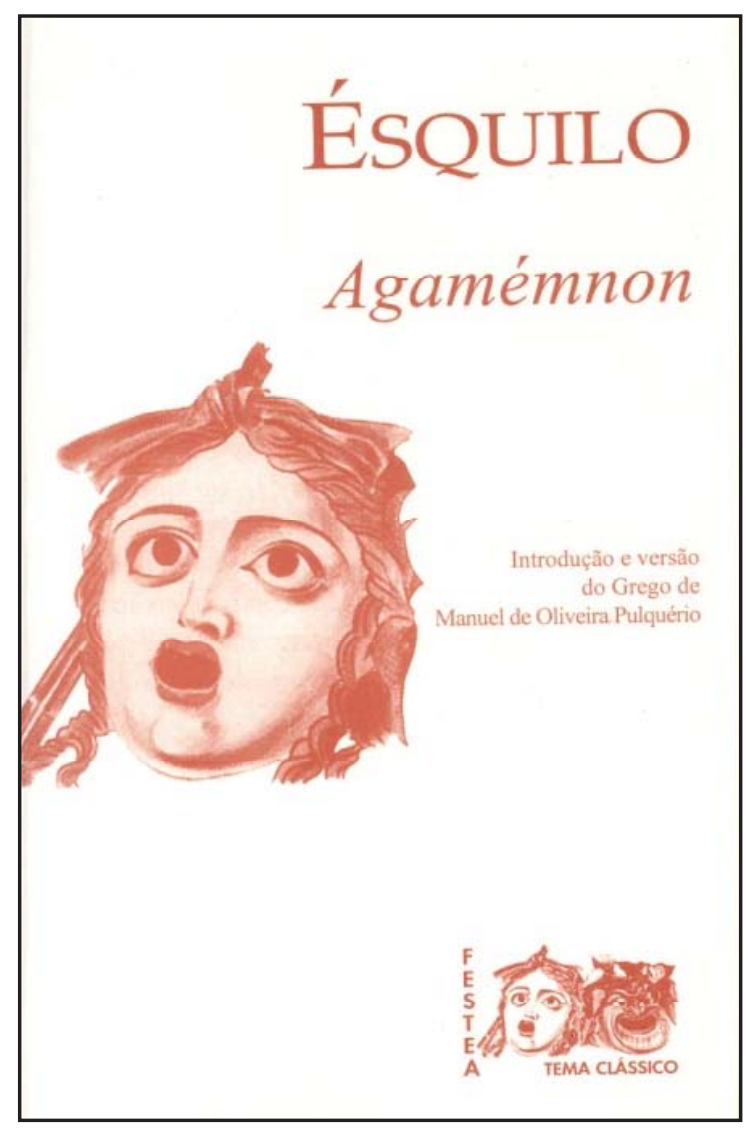

Autor

Ésquilo

Título

Agamémnon

Tradução

Manuel de Oliveira Pulquério

Ano de edição

2007, ${ }^{2} 2008$

Editor

FESTEA - Tema Clássico

Autor

Ésquilo

Título

As Coéforas

Tradução

Manuel de Oliveira Pulquério

Ano de edição

2001

Editor

Ediciones Clásicas

Liga de Amigos de Conimbriga
Autor

Sófocles

Título

Édipo em Colono

Tradução

Maria do Céu Fialho

Ano de edição

2001

Editor

Ediciones Clásicas

Liga de Amigos de Conimbriga

Autor

Sófocles

Título

Rei Édipo

Tradução

Maria do Céu Fialho

Ano de edição

2003, ${ }^{2} 2009$

Editor

Ediciones Clásicas

Liga de Amigos de Conimbriga

\section{SÓFOCLES}

Rei Édipo

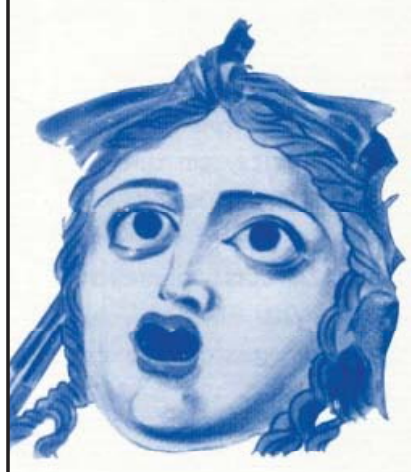

Introdução e versão

do grego de

Maria do Cé

Zambujo Fialho

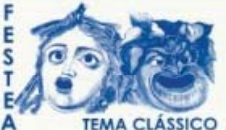


Autor

Sófocles

Título

Antígona

Tradução

Maria Helena da Rocha Pereira

Ano de edição

2003, ${ }^{2} 2006$

Editor

FESTEA - Tema Clássico

Autor

Sófocles

Título

As Traquínias

Tradução

Maria do Céu Fialho

Ano de edição

2003

Editor

Ediciones Clásicas

FESTEA-Tema Clássico
Autor

Eurípides

Título

Os Heraclidas

Tradução

Cláudia Raquel Cravo da Silva

Ano de edição 2001

Editor

Ediciones Clásicas

Liga de Amigos de Conimbriga

\author{
Autor \\ Eurípides \\ Título \\ Electra \\ Tradução \\ Fernanda Brasete \\ Ano de edição \\ 2002 \\ Editor \\ Ediciones Clásicas \\ Liga de Amigos de Conimbriga
}

\author{
Autor \\ Eurípides \\ Título \\ As Troianas \\ Tradução \\ Maria Helena da Rocha Pereira \\ Ano de edição \\ 2005 \\ Editor \\ FESTEA - Tema Clássico
}

Autor

Eurípides

Título

Íon

Tradução

Manuel de Oliveira Pulquério

Maria M. S. Álvares

Ano de edição

2001

Editor

Ediciones Clásicas

Liga de Amigos de Conimbriga
Autor

Eurípides

Título

Hipólito

Tradução

Frederico Lourenço

Ano de edição

2006

Editor

FESTEA - Tema Clássico 
Autor

Eurípides

Título

As Suplicantes

Tradução

José Ribeiro Ferreira

Ano de edição

2006

Editor

FESTEA - Tema Clássico

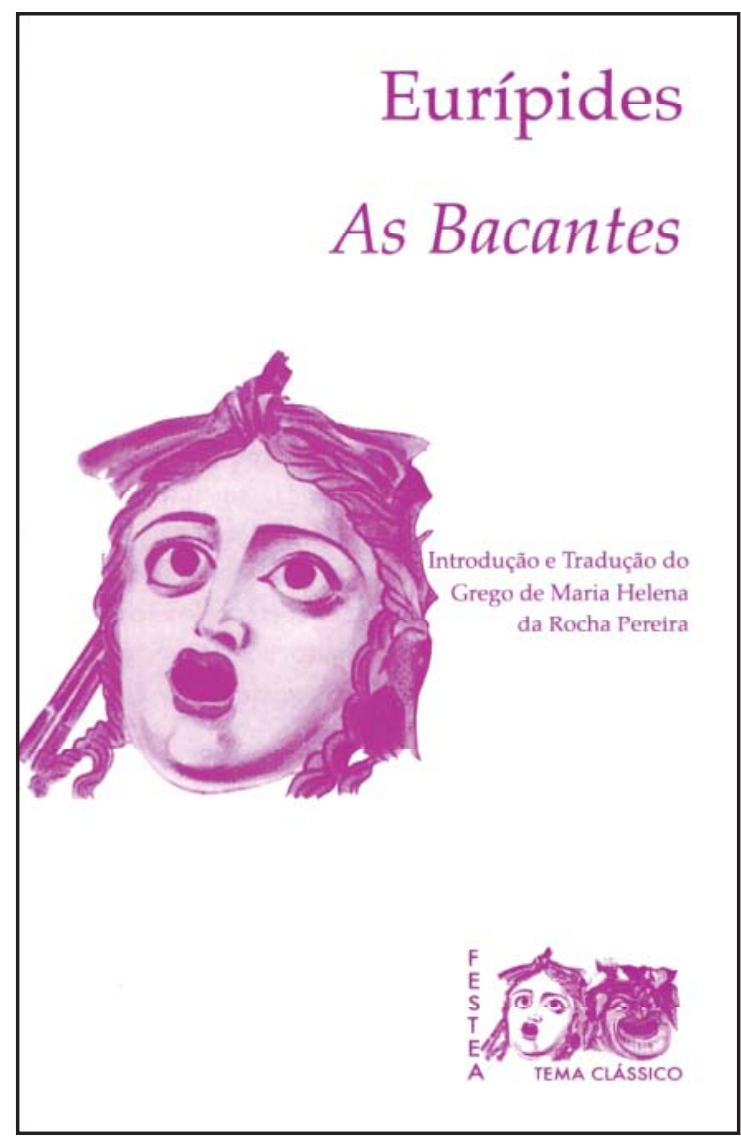

Autor

Eurípides

Título

As Bacantes

Tradução

Maria Helena da Rocha Pereira

Ano de edição

2008

Editor

FESTEA - Tema Clássico
Autor

Eurípides

Título

Andrómaca

Tradução

José Ribeiro Ferreira

Ano de edição

2005

Editor

Ediciones Clásicas

Liga de Amigos de Conimbriga

Autor

Eurípides

Título

Helena

Tradução

José Ribeiro Ferreira

Ano de edição

2005

Editor

FESTEA - Tema Clássico

Autor

Eurípides

Título

Ifigénia em Áulide

Tradução

C. A. Pais de Almeida

Ano de edição

2008

Editor

FESTEA - Tema Clássico

\section{Autor}

Aristófanes

Título

Lisístrata

Tradução

Maria de Fátima Silva

Ano de edição

2002

Editor

Ediciones Clásicas

Liga de Amigos de Conimbriga 
Autor

Aristófanes

Título

As Rãs

Tradução

Américo da Costa Ramalho

Ano de edição

2004

Editor

FESTEA - Tema Clássico

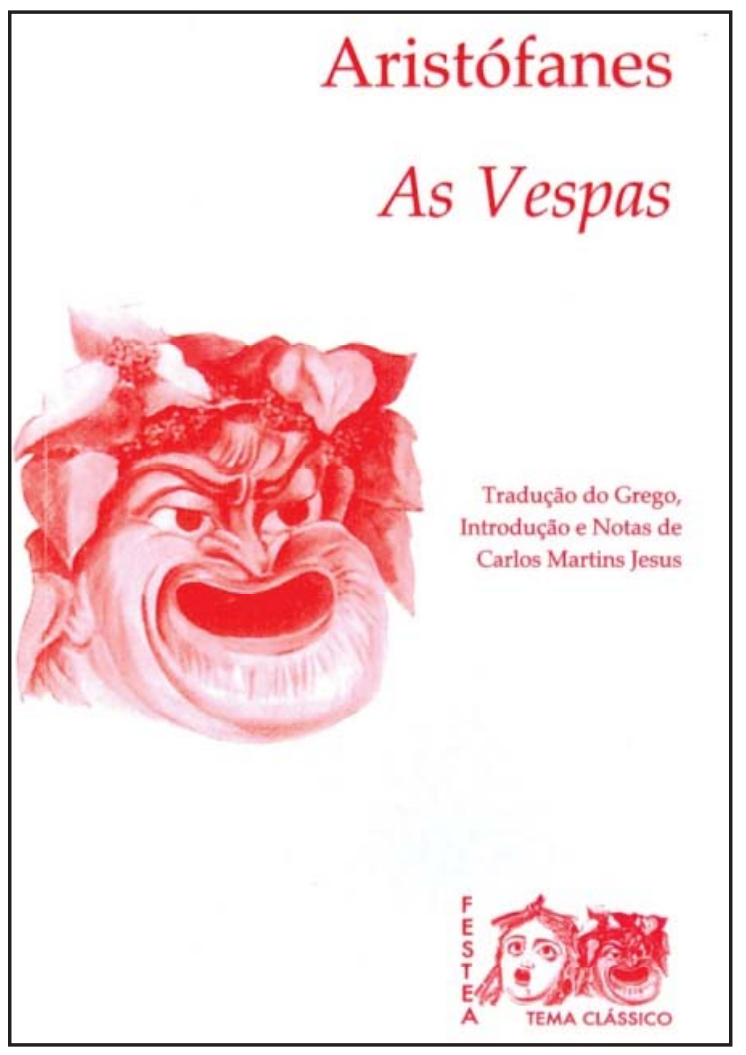

Autor

Aristófanes

Título

As Vespas

Tradução

Carlos A. Martins Jesus

Ano de edição

2008, ${ }^{2} 2009$

Editor

FESTEA - Tema Clássico
Autor

Aristófanes

Título

As Mulheres no Parlamento

Tradução

Maria de Fátima Silva

Ano de edição

2005, ${ }^{2} 2006$

Editor

FESTEA - Tema Clássico

Autor

Aristófanes

Título

Pluto (A Riqueza)

Tradução

Américo da Costa Ramalho

Ano de edição

2005

Editor

FESTEA - Tema Clássico

MENANDRO

A Rapariga de Samos

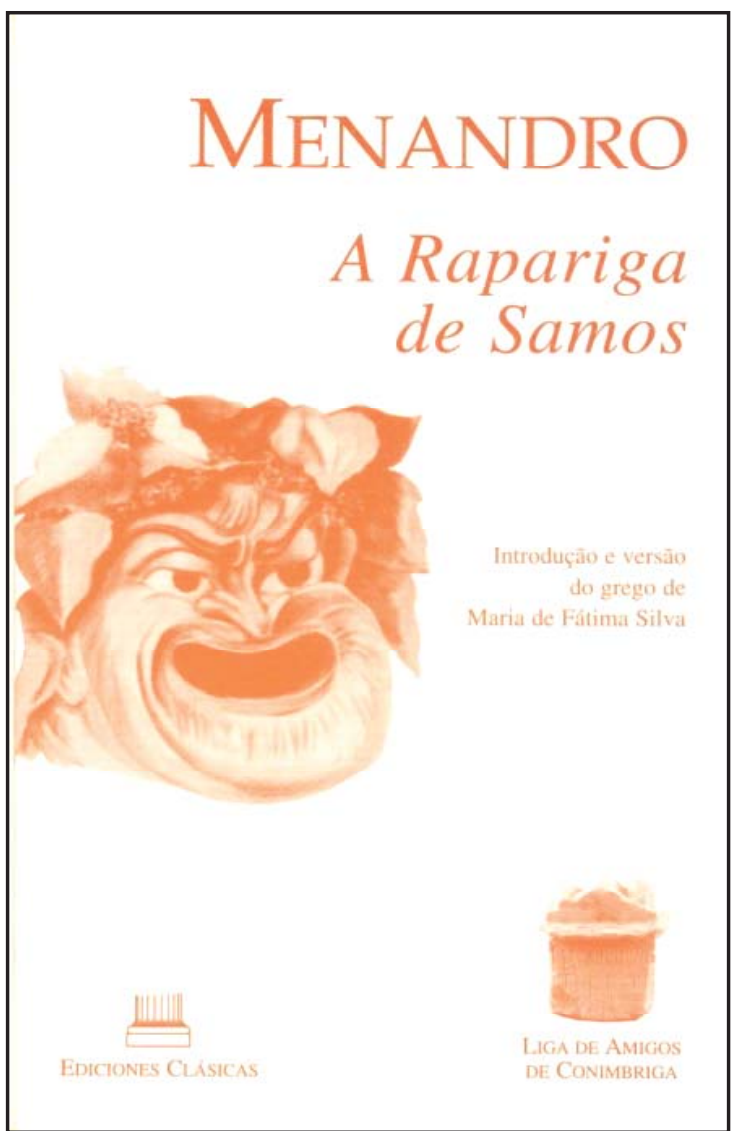


Autor

Menandro

Título

A Rapariga de Samos

Tradução

Maria de Fátima Silva

Ano de edição

2000

Editor

Ediciones Clásicas

Liga de Amigos de Conimbriga

Autor
Plauto
Título
Epídico
Tradução
Walter de Medeiros
Ano de edição
2000
Editor
Ediciones Clásicas
ga de Amigos de Conimbriga

Autor
Plauto
Título
O Gorgulho
Tradução
Walter de Medeiros
Ano de edição
2000
Editor
Ediciones Clásicas
de Amigos de Conimbriga

Autor

Plauto

Título

A Comédia da Marmita (Aulularia)

Tradução

Walter Medeiros

Ano de edição

2001

Editor

Ediciones Clásicas

Liga de Amigos de Conimbriga
Autor

Plauto

Título

O Anfitrião

Tradução

Carlos A. Louro da Fonseca

Ano de edição

2002

Editor

Ediciones Clásicas

Liga de Amigos de Conimbriga

Autor

Plauto

Título

A Comédia do Fantasma (Mostellaria)

Tradução

Reina M. Troca Pereira

Ano de edição

2002

Editor

Ediciones Clásicas

Liga de Amigos de Conimbriga

\author{
Autor \\ Plauto \\ Título \\ Os dois Menecmnos \\ Tradução \\ Carlos A. Louro da Fonseca \\ Ano de edição \\ 2002 \\ Editor \\ Ediciones Clásicas \\ Liga de Amigos de Conimbriga
}


Autor

Plauto

Título

O Soldado Fanfarrão

Tradução

Carlos A. Louro da Fonseca

Ano de edição

2004, ${ }^{2} 2006$

Editor

FESTEA - Tema Clássico

Autor

Plauto

Título

A Comédia os Burros

Tradução

Aires Pereira do Couto

Ano de edição

2007

Editor

FESTEA - Tema Clássico

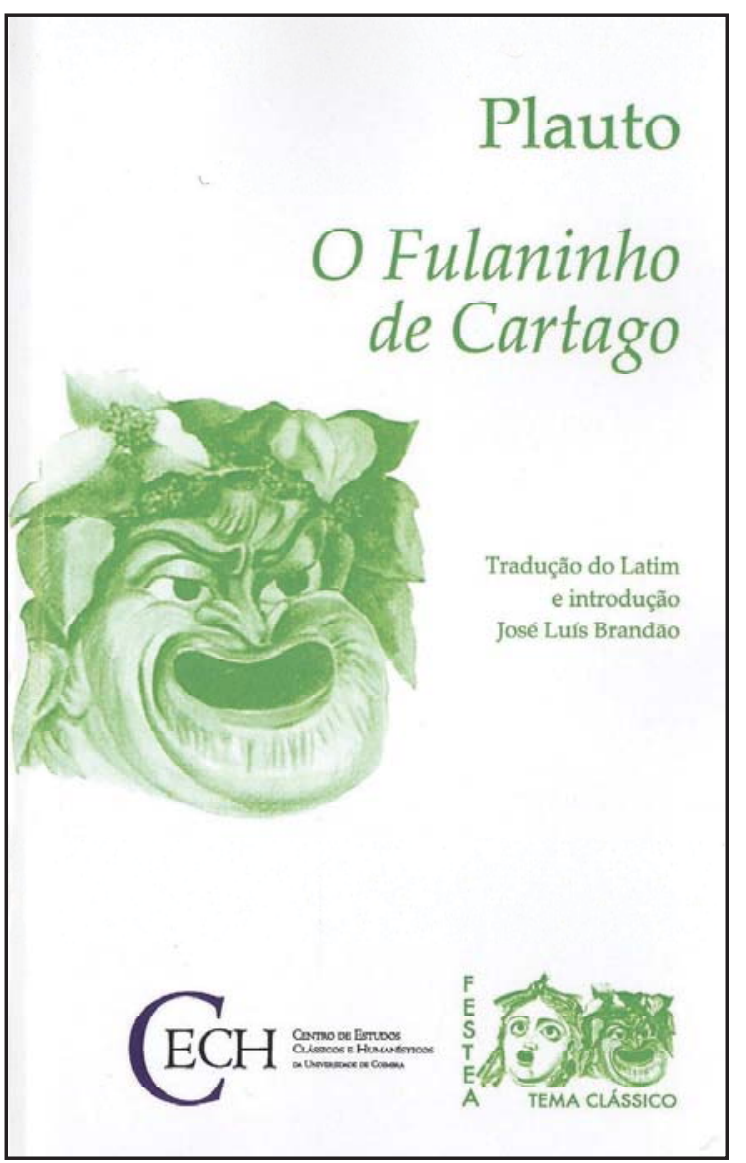

Autor

Plauto

Título

O Fulaninho de Cartago

Tradução

José Luís Brandão

Ano de edição

2009

Editor

FESTEA - Tema Clássico

Centro de Estudos Clássicos e Humanísticos

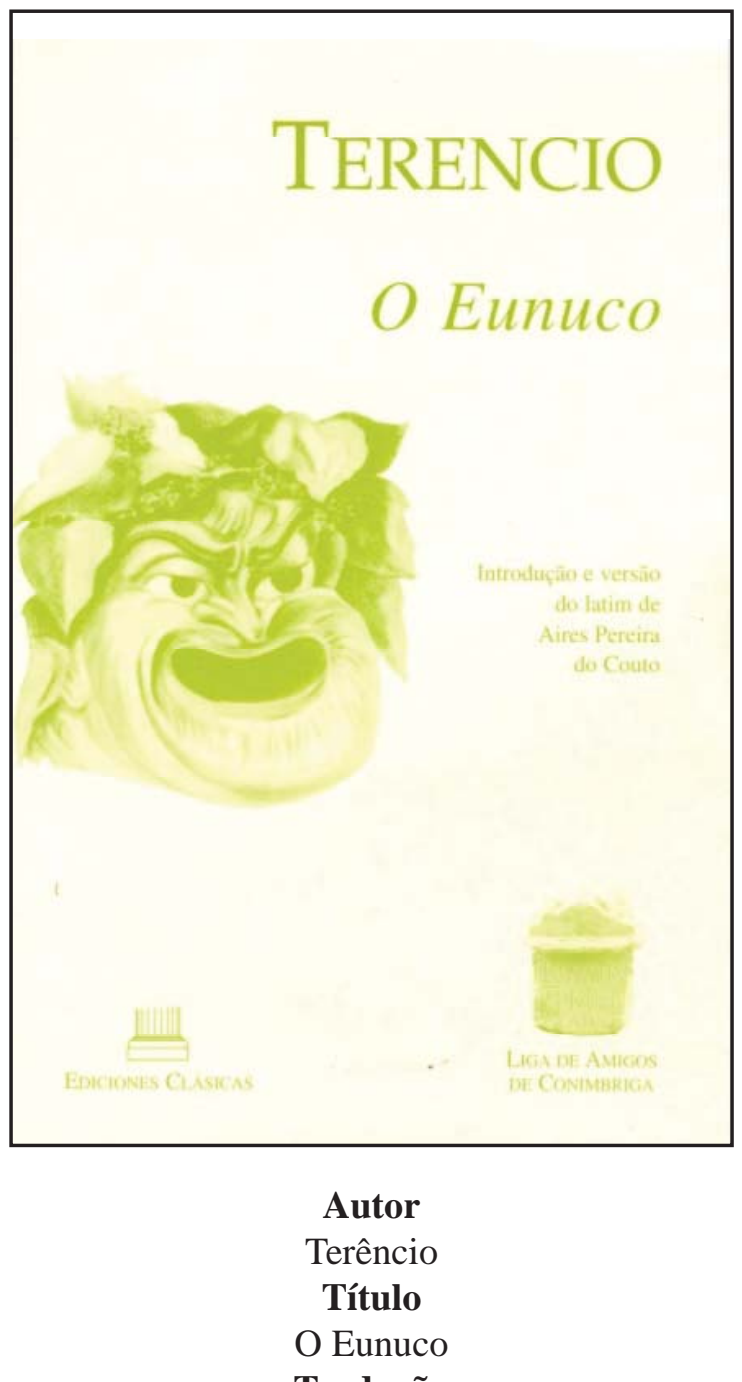

O Eunuco

Tradução

Aires Pereira do Couto

Ano de edição

2002

Editor

Ediciones Clásicas

Liga de Amigos de Conimbriga 
Autor

AAVV

Título

Mitos Clássicos

na Poesia Portuguesa Contemporânea

Selecção

José Ribeiro Ferreira

Ano de edição

2000

Editor

Ediciones Clásicas

Liga de Amigos de Conimbriga

Composição

C. W. Gluck

Libreto

Ranieri De’ Calzabigi

Título

Orfeu e Eurídice

Tradução

Lino Mioni

Ano de edição

2001

Editor

Ediciones Clásicas

Liga de Amigos de Conimbriga

Autor

Marcial

Título

Marcial em Traje de Cena

Tradução

Delfim Ferreira Leão

José Luís Brandão

Paulo Sérgio Ferreira

Selecção

José Luís Brandão

Ano de edição

2004

Editor

FESTEA - Tema Clássico
Autor

Teócrito e Virgílio

Título

Teócrito e Virgílio

Tradução

M. H. Rocha Pereira

M. M. Barbosa du Bocage

Ano de edição

2005

Editor

FESTEA - Tema Clássico

Autor

Esopo

Título

Fábulas

Tradução

Nelson H. S. Ferreira

Ilustrações

Katia C. Galhano

Ano de edição

2009

Editor

FESTEA - Tema Clássico

Centro de Estudos Clássicos e Humanísticos

Autor

Chantal Collion

Título

Como é doce a guerra...

Tradução

Ana Seiça Carvalho

Ano de edição

2008

Editor

FESTEA - Tema Clássico 


\section{Grupos participantes e espaços}

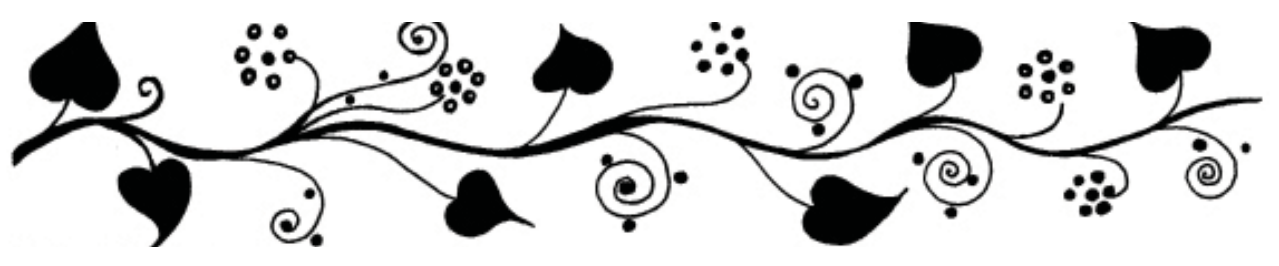




\section{GRUPOS PARTICIPANTES}

A Escola da Noite de Coimbra

Ágon de Caldas da Rainha

Angelus do Colégio de S. Miguel (Fátima)

Arthistrión/Calatalifa de Madrid

Balbo do IES de Puerto Sta. María (Cádis)

Batrakoi da Faculdade de Letras da Universidade de Lisboa

Calatalifa de Madrid

Canto e Drama do Conservatório de Música de Coimbra

Escola Superior de Teatro e Cinema de Amadora

Fatias de Cá de Tomar

Grupo de Teatro Clássico da Escola Superior de Arte Dramática (Málaga)

Grupo de Teatro Clássico da Universidade de Alicante

Grupo de Teatro Clássico de Conimbriga

Grupo de Teatro da Escola Secundária de Cantanhede

Grupo de teatro da Escola Secundária de Trancoso

Helios Teatro de Madrid

Les Enfants de Nysa da École Supérieur de Réalisation Audiovisuelle (Paris)

Meia Via de Torres Novas

Sardiña do IES Elpiña, Corunha

Selene do IES Carlos III de Madrid

Teat®amus do Colégio de Calvão

Theatro do Lyceu da Figueira da Foz

Thíasos do Instituto de Estudos Clássicos

\section{ESPAÇOS E INSTITUIÇÕES QUE ACOLHERAM O FESTIVAL}

Antigo Convento de Santana (Coimbra)

Antigo Mercado de Viseu

Aparthotel Sottomayor (Figueira da Foz)

Auditório Mirita Casimiro (Viseu)

Auditório Municipal de Santiago da Guarda

Biblioteca Joanina da Universidade de Coimbra

Câmara Municipal de Miranda do Corvo

Câmara Municipal de Tomar

Castelo de Penela

Castelo de Pinhel

Castelo Rodrigo

Centro Cultural D. Dinis (Coimbra)

Centro Cultural da Mêda

Centro de Arte e Espectáculos da Figueira da Foz 
Claustros da Sé Velha de Coimbra

Claustros de Santa Cruz (Coimbra)

Claustros do Seminário de Viseu

Convento de Cristo (Tomar)

Convento de S. Francisco (Coimbra)

Festival Européen Latin et Grec 2007 (Nantes, França)

Instituto Português da Juventude de Coimbra

Instituto Universitário Justiça e Paz (Coimbra)

Jardim Botânico de Coimbra

Largo da Sé de Braga

Louriçal

Mosteiro de S. Martinho de Tibães (Braga)

Museu Arqueológico de S. Miguel de Odrinhas (Sintra)

Museu D. Diogo de Sousa (Braga)

Museu da Citânia de Sanfins

Museu do Vinho de Anadia

Museu Grão-Vasco (Viseu)

Museu Monográfico de Conimbriga

Museu Nacional Machado de Castro

Parque das Tílias (Fundão)

Páteo da Universidade de Coimbra

Pátio da Inquisição (Coimbra)

Pátio do Palácio dos Figueiredos (Condeixa)

Pátio Grego da Faculdade de Letras da Universidade de Lisboa

Pólo de Viseu da Universidade Católica

Praça 8 de Maio (Coimbra)

Praça do Município de Nelas

Quinta do Ervedal (Castelo Novo)

Salão dos Bombeiros Voluntários de Condeixa

Teatro Académico Gil Vicente

Teatro do Colégio de S. Teotónio (Coimbra)

Teatro Paulo Quintela da Faculdade de Letras da Universidade de Coimbra

Teatro Viriato (Viseu)

Termas Romanas de Braga

Tours (França)

Vila Nova de Foz Côa 
Índice de espectáculos

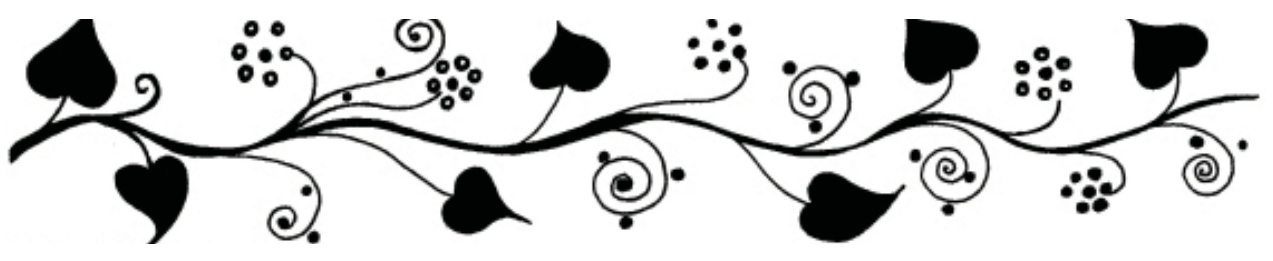


ÉSQUILO

Agamémnon

As Coéforas

Persas

SÓFOCLES

Antígona

Édipo em Colono

Electra

Filoctetes

Rei Édipo

Traquínias

\section{EURÍPIDES}

Andrómaca

Bacantes

Electra

Hécuba

Helena

Heraclidas

Hipólito

Ifigénia em Áulide

Íon

Suplicantes

Troianas

\section{ARISTÓFANES}

Lisístrata

Mulheres no Parlamento

$\mathrm{Paz}$

Pluto (A Riqueza)

Rãs

Vespas

\section{MENANDRO}

112-113

A Rapariga de Samos

20-21, 89

46-47

24-25

PLAUTO

Anfitrião

56-57

Comédia dos Burros

114

76

48-49

58-59, 89-90

Comédia da Cestinha

85

Comédia do Fantasma

66-67

Comédia da Marmita

44-45

74-75

72-73

Epídico

22-23

Gorgulho

34, 116-117

Os Dois Menecmos

64, 83

Persa

100

Soldado Fanfarrão

88, 109

\section{TERÊNCIO}

126-127

63

115

101-102

40-42

105

121, 124-125

50-51

108-109

35-37

Eunuco

62

\section{TEMA CLÁSSICO}

Antígona, de A. Pedro

65

Como é doce a guerra...

128-129

Marcial em Trajes de Cena

81-82

Mitos Clássicos na Poesia

Portuguesa Contemporânea

26-27

O Corpo de Helena, de A. J. Miranda 77

Poeta e Maçador 52-53

Teócrito e Virgílio 96-97

60-61

94-95

86-87

Ulisses, de M. A. Menéres

98

Viriato, de J. Aguiar

28-29

\section{ESPECTÁCULOS MUSICAIS}

84

$122-123$
Dido e Eneias, de H. Purcell

Orfeu e Eurídice, de C. Gluck
18-19 


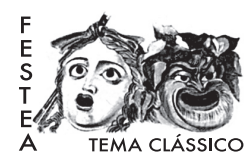

ECH Clantricos e Humanosísticos 